Prepared in cooperation with the CITY OF OLATHE, KANSAS and the KANSAS DEPARTMENT OF HEALTH AND ENVIRONMENT

\title{
Surface-Water-Quality Conditions and Relation to Taste-and-Odor 0ccurrences in the Lake Olathe Watershed, Northeast Kansas, 2000-02
}

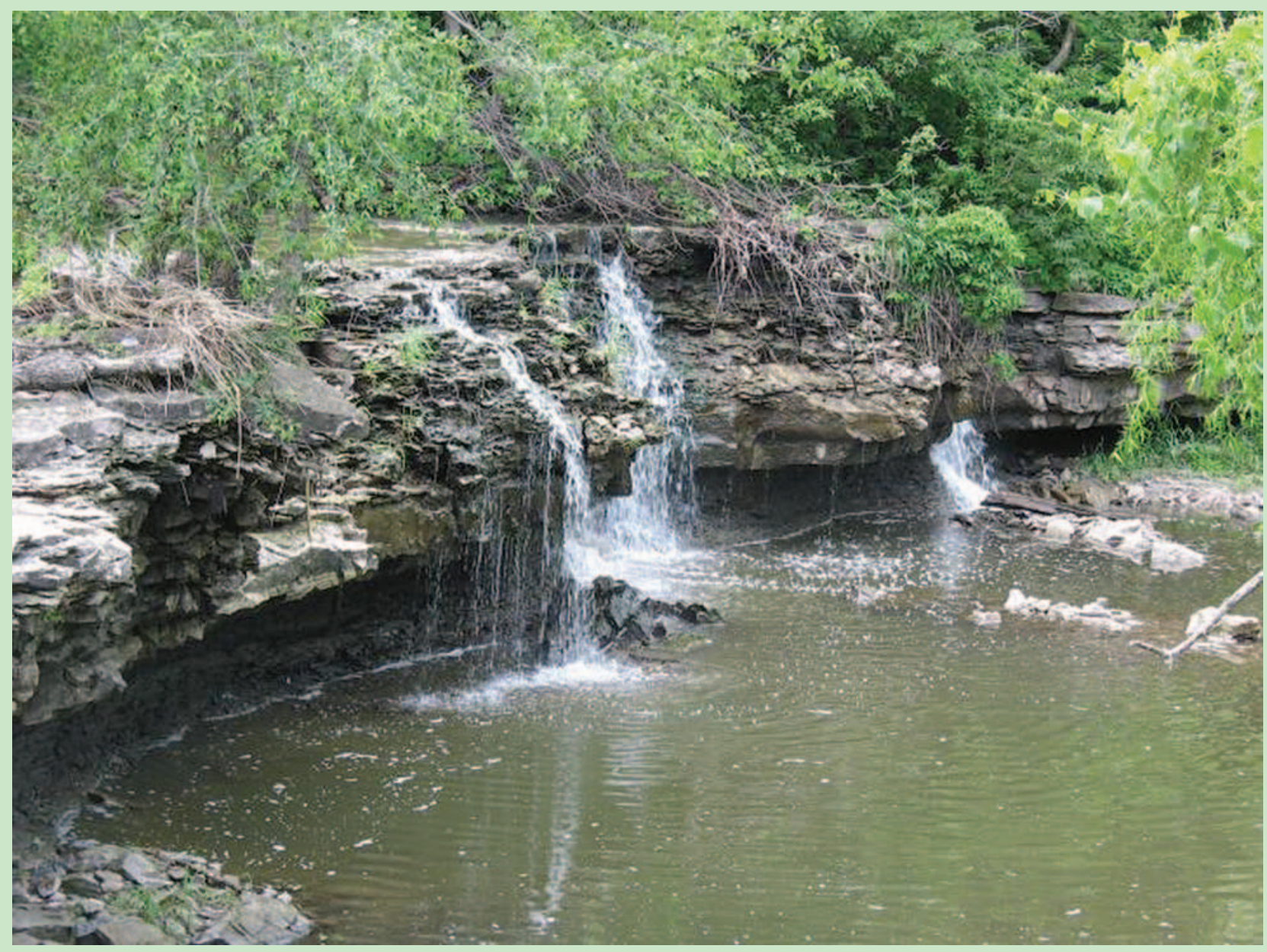

Scientific Investigations Report 2004-5047 


\section{Surface-Water-Quality Conditions and Relation to Taste-and-Odor Occurrences in the Lake Olathe Watershed, Northeast Kansas, 2000-02}

By David P. Mau, Andrew C. Ziegler, Stephen D. Porter, and Larry M. Pope

Prepared in cooperation with the CITY OF OLATHE, KANSAS, and the

KANSAS DEPARTMENT OF HEALTH AND ENVIRONMENT

Scientific Investigations Report 2004-5047 


\title{
U.S. Department of the Interior Gale A. Norton, Secretary
}

\author{
U.S. Geological Survey \\ Charles G. Groat, Director
}

\section{U.S. Geological Survey, Reston, Virginia: 2004}

\author{
For sale by U.S. Geological Survey, Information Services \\ Box 25286, Denver Federal Center \\ Denver, CO 80225 \\ For more information about the USGS and its products: \\ Telephone: 1-888-ASK-USGS \\ World Wide Web: http://www.usgs.gov/
}

Any use of trade, product, or firm names in this publication is for descriptive purposes only and does not imply endorsement by the U.S. Government.

Although this report is in the public domain, permission must be secured from the individual copyright owners to reproduce any copyrighted materials contained within this report.

Suggested citation:

Mau, D.P., Ziegler, A.C., Porter, S.D., and Pope, L.M., 2004, Surface-water-quality conditions and relation to taste-andodor occurrences in the Lake Olathe watershed, northeast Kansas, 2000-02: U.S. Geological Survey Scientific Investigations Report 2004-5047, 95 p. 


\section{Contents}

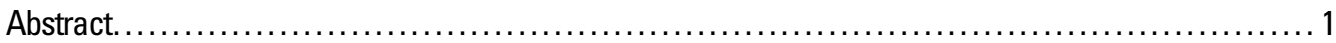

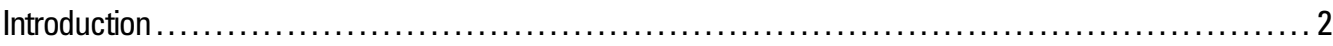

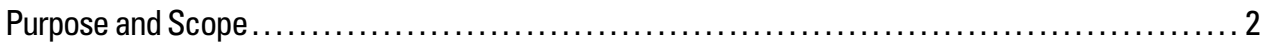

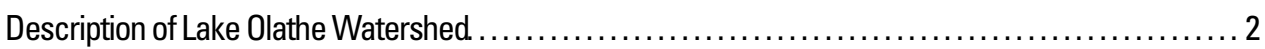

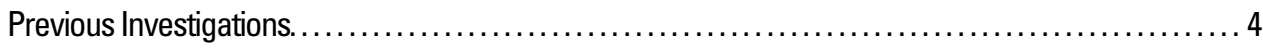

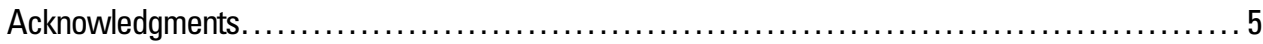

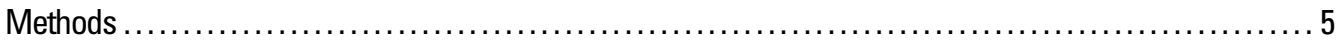

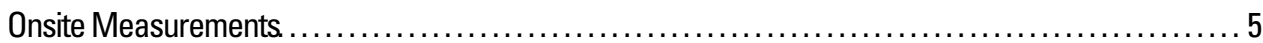

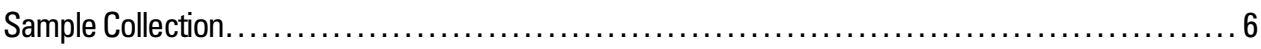

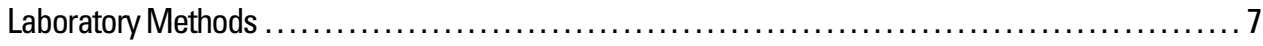

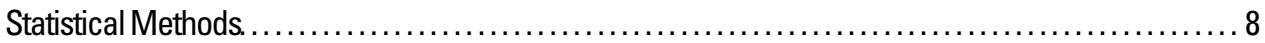

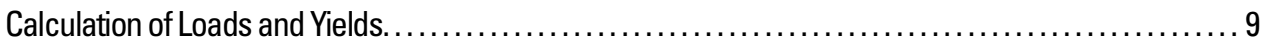

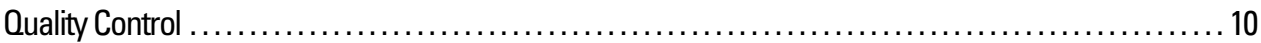

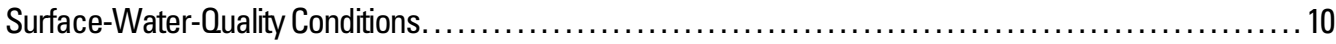

Water Chemistry of Cedar Creek and Lake Olathe .................................... 10

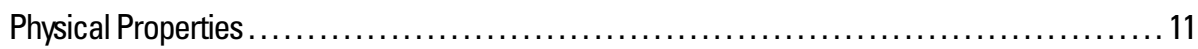

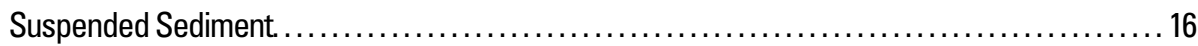

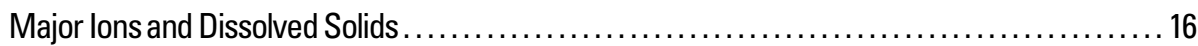

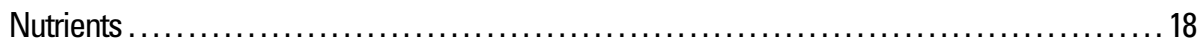

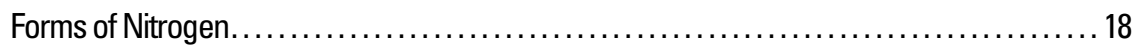

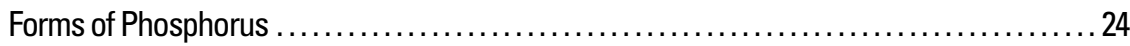

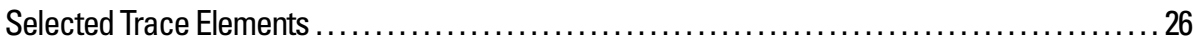

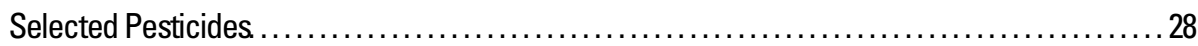

Suspended Sediment and Nutrient Loads and Yields in Cedar Creek and Lake Olathe............... 31

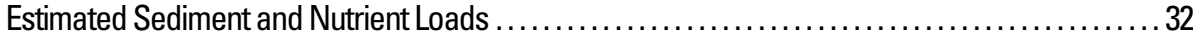

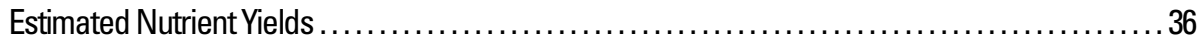

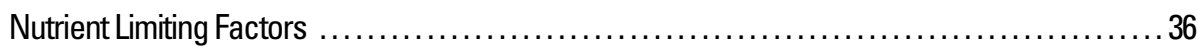

Relation of Chlorophyll and Nutrients to Trophic State of Lake Olathe .................... 39

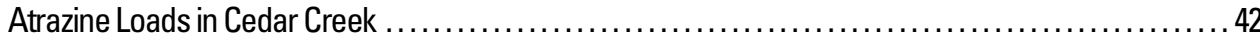

Bacteria Densities, Loads, and Yields in Cedar Creek and Lake Olathe ....................... 43

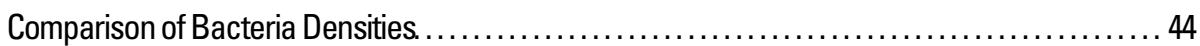

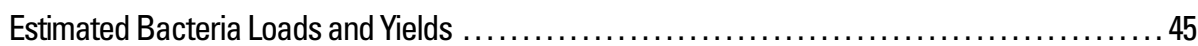

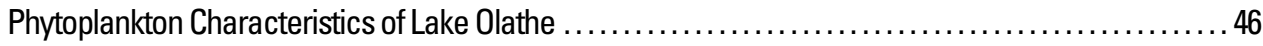

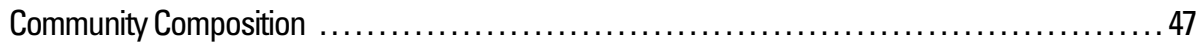

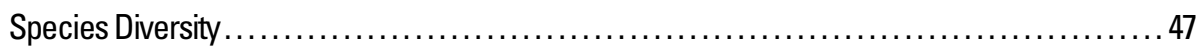

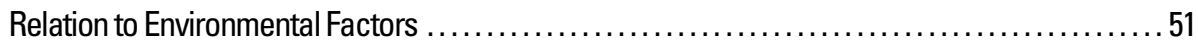

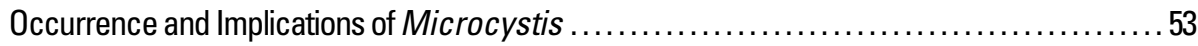

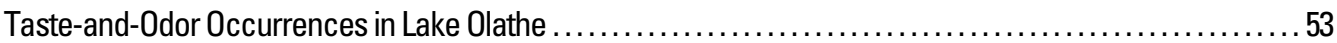

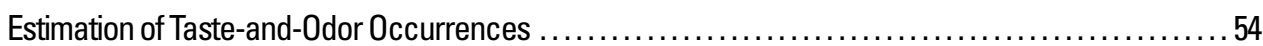

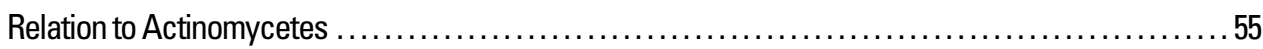

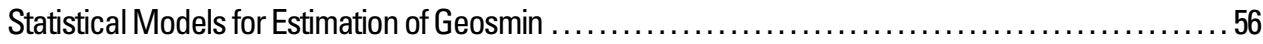

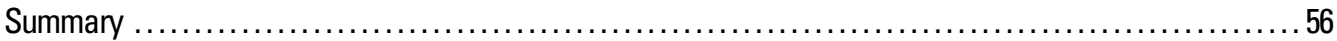




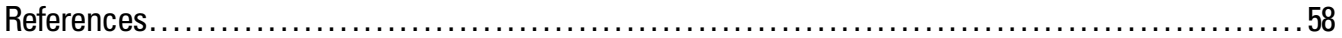

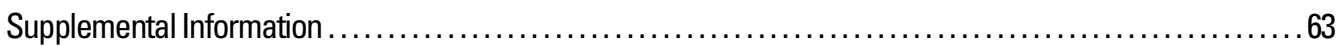

\section{Figures}

1. Map showing location of Lake Olathe watershed in northeast Kansas, water-quality sampling

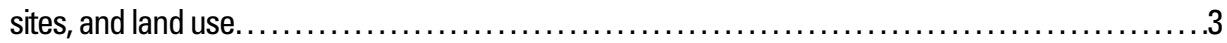

2. Photograph showing multiparameter monitor used to measure specific conductance, $\mathrm{pH}$, water temperature, turbidity, dossolved oxygen, and fluorescence in water during sample collection and for in-stream and in-lake continuous monitoring .........................6

3-14. Graphs showing:

3. Concentrations of chlorophyll-a in water samples analyzed using high-performance liquid chromatography in relation to concentrations analyzed using a continuous real-time

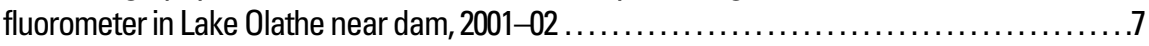

4. Mean daily $(A)$ specific conductance and turbidity, and $(B) \mathrm{pH}$, water temperature, and dissolved oxygen in water from Cedar Creek at Highway 56, 2001-02 .................. 14

5. Mean daily $(A)$ specific conductance and turbidity, and $(B) \mathrm{pH}$, water temperature, and

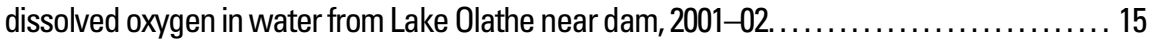

6. Mean daily stream discharge from Cedar Creek at Highway $56,2001-02 \ldots \ldots \ldots \ldots \ldots \ldots \ldots \ldots$

7. Water temperature variation with depth in Lake Olathe near dam, $2001 \ldots \ldots \ldots \ldots \ldots \ldots \ldots . .17$

8. Concentrations of atrazine in water samples analyzed using immunoassay in relation to concentrations analyzed using gas chromatography/mass spectrometry for Cedar Creek at Highway 56 and Lake Olathe near dam, 2000-02. .

9. Detection frequency of selected pesticide compounds in water from Cedar Creek at Highway 56 and Lake Olathe near dam, 2000-02, at concentrations greater than or equal to

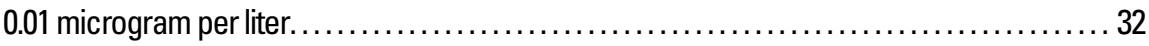

10. Concentrations of atrazine in water samples collected from Cedar Creek at Highway 56

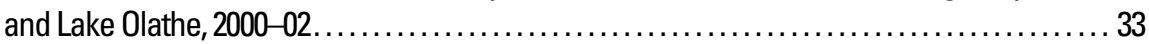

11. Estimated seasonal loads of suspended sediment and selected nutrients compared to seasonal precipitation for Cedar Creek at Highway 56, 2001-02 ..................... 35

12. Total biovolume in epilimnion of Lake Olathe near dam, $2000-02 \ldots \ldots \ldots \ldots \ldots \ldots \ldots \ldots \ldots$

13. Relative percentage abundance of phytoplankton divisions and geosmin concentrations

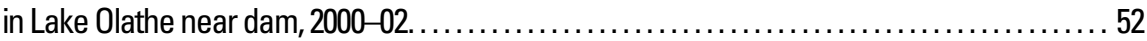

14. Concentrations of geosmin, actinomycetes, and microcystin in Lake Olathe near dam,

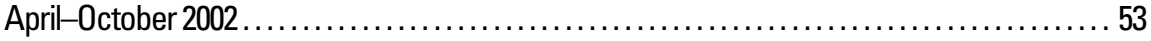

\section{Tables}

1. Physical characteristics of Cedar Lake and Lake Olathe near Olathe, northeast Kansas...........

2. Statistical summary describing physical properties, organic carbon, and suspended-sediment concentrations in water from Cedar Creek at Highway 56 and Lake Olathe, northeast Kansas,

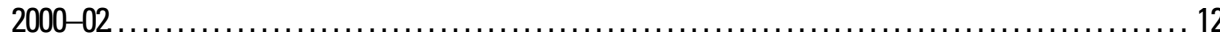

3. Statistical summary describing major-ion and dissolved-solids concentrations in water from Cedar Creek at Highway 56 and Lake Olathe, northeast Kansas, 2000-02 _................. 19

4. Statistical summary describing nutrient concentrations in water from Cedar Creek at Highway 56 and Lake Olathe, northeast Kansas, 2000-02. 
5. Summary of regression model equations for selected constituents in water from Cedar Creek at

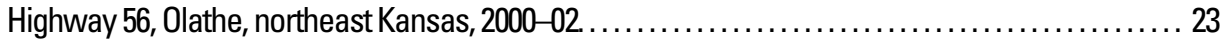

6. Summary of regression model equations for selected constituents in water from epilimnion of

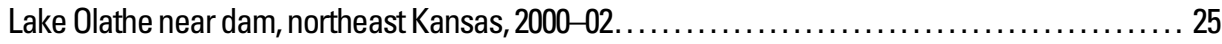

7. Statistical summary describing selected trace-element concentrations in water from Cedar Creek

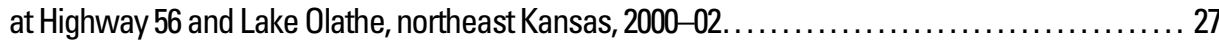

8. Statistical summary describing selected pesticide concentrations in water from Cedar Creek at

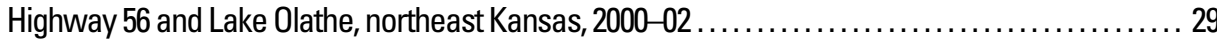

9. Summary of estimated seasonal and annual loads of suspended sediment and nutrient loads in

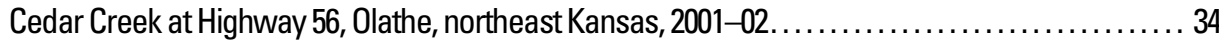

10. Estimated annual and mean annual nutrient loads and yields for Cedar Creek at Highway 56,

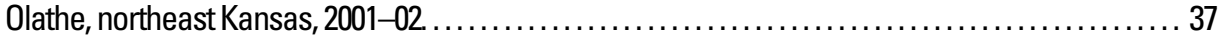

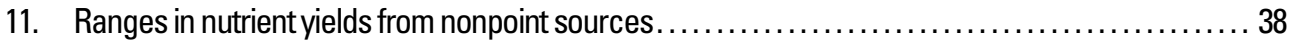

12. Total estimated sediment deposition, phosphorus concentrations, and phosphorus loads and

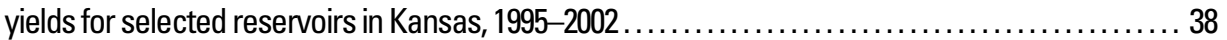

13. Limiting factor analysis for Lake Olathe near dam, northeast Kansas, $2000-02 \ldots \ldots \ldots \ldots \ldots . \ldots 40$

14. Kansas lake-use impairment identification system................................... 41

15. Mean trophic-state index values for Lake Olathe near dam, northeast Kansas, $2000-02 \ldots \ldots \ldots . .42$

16. Hydraulic residence-time analysis for Lake Olathe near dam, northeast Kansas, 2001-02 ........ 43

17. Seasonal and total annual estimates of atrazine loads in Cedar Creek at Highway 56, northeast

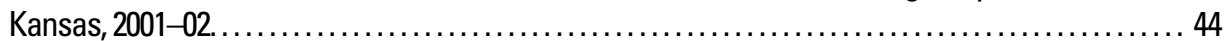

18. Statistical summary describing bacteria concentrations in water from Cedar Creek at

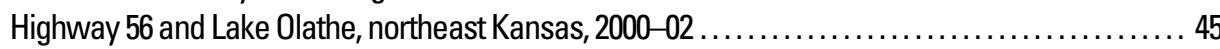

19. Seasonal and annual estimates of bacteria loads and yields from Cedar Creek at Highway 56,

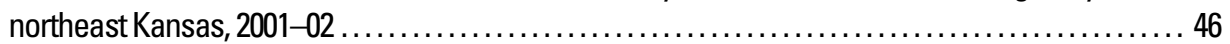

20. Statistical summary describing phytoplankton-related concentrations in water from Cedar Creek at Highway 56 and Lake Olathe, northeast Kansas, 2000-02 ....................... 48

21. Simpson's and Shannon-Wiener Diversity Index values for Cedar Creek at Highway 56 and

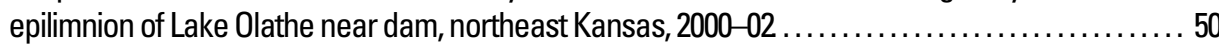

22. Specifications for the multiparameter YSI 6600 monitor .................................. 64

23. Inorganic water-quality constituents, parameter codes, and detection levels for water-quality samples collected from Cedar Creek at Highway 56 and Lake Olathe near Olathe, northeast Kansas, 2000-02

24. Organic water-quality constituents, parameter codes, and reporting limits for samples collected from Cedar Creek at Highway 56 and Lake Olathe near Olathe, northeast Kansas, $2000-02$

25. Results of equipment and rinse blank analysis of water-quality samples collected from Lake

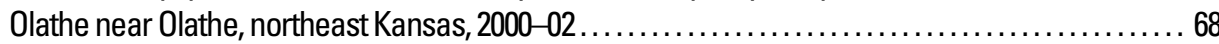

26. Results of replicate sample analysis for water-quality samples collected from Lake Olathe near dam,

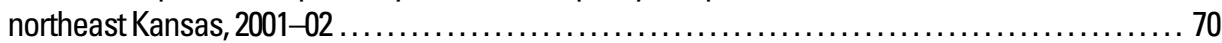

27. Phytoplankton taxa, biovolume, and relative percentage abundance in water from Cedar Creek

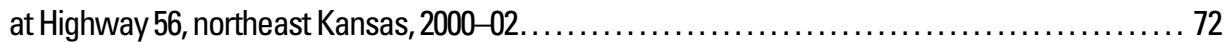

28. Phytoplankton taxa, biovolume, and relative percentage abundance in water from Lake Olathe

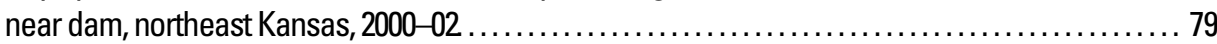




\section{Conversion Factors, Water-Quality Abbreviations, Datums, and Acronymns}

\section{Conversion Factors}

\begin{tabular}{lcl}
\hline Multiply & \multicolumn{1}{c}{ By } & To obtain \\
\hline acre & 4,047 & square meter $\left(\mathrm{m}^{2}\right)$ \\
acre-foot (acre-ft) & 1,233 & cubic meter $\left(\mathrm{m}^{3}\right)$ \\
acre-foot per day (acre-ft/d) & 1,233 & cubic meter per day $\left(\mathrm{m}^{3} / \mathrm{d}\right)$ \\
acre-foot per square mile $\left(\mathrm{acre}-\mathrm{ft} / \mathrm{mi}^{2}\right)$ & 476.1 & cubic meter per square $\mathrm{kilometer}\left(\mathrm{m}^{3} / \mathrm{km}^{2}\right)$ \\
cubic foot per second $\left(\mathrm{ft}^{3} / \mathrm{s}\right)$ & 0.02832 & cubic meter per second $\left(\mathrm{m}^{3} / \mathrm{s}\right)$ \\
foot $(\mathrm{ft})$ & 0.3048 & meter $(\mathrm{m})$ \\
gram per square meter per year & 8.9218 & pound per acre per year $[(\mathrm{lb} / \mathrm{acre}) / \mathrm{yr}]$ \\
$\quad\left[\left(\mathrm{g} / \mathrm{m}^{2}\right) / \mathrm{yr}\right]$ & & \\
inch $($ in. $)$ & 2.54 & centimeter $(\mathrm{cm})$ \\
meter $(\mathrm{m})$ & 3.281 & foot $(\mathrm{ft})$ \\
meter per year $(\mathrm{m} / \mathrm{yr})$ & 3.281 & foot per year $(\mathrm{ft} / \mathrm{yr})$ \\
mile $(\mathrm{mi})$ & 1.609 & kilometer $(\mathrm{km})$ \\
liter $(\mathrm{L})$ & 33.82 & ounce, fluid $(\mathrm{oz})$ \\
microgram per liter $(\mu \mathrm{g} / \mathrm{L})$ & 1.0 & part per billion $(\mathrm{ppb})$ \\
micrometer $(\mu \mathrm{m})$ & 0.00003937 & inch $($ in. $)$ \\
milligram per kilogram $(\mathrm{mg} / \mathrm{kg})$ & 0.00016 & ounce per pound $(\mathrm{oz} / \mathrm{lb})$ \\
milligram per liter & 1.0 & part per million $(\mathrm{ppm})$ \\
nanogram per liter $(\mathrm{ng} / \mathrm{L})$ & 1.0 & part per trillion $(\mathrm{ppt})$ \\
pound $(\mathrm{lb})$ & 453.6 & gram $(\mathrm{g})$ \\
pound per acre $(\mathrm{lb} / \mathrm{acre})$ & 1.121 & kilogram per hectare $(\mathrm{kg} / \mathrm{ha})$ \\
pound per acre per year $[(\mathrm{lb} / \mathrm{acre}) / \mathrm{yr}]$ & 1.121 & kilogram per hectare per year $[(\mathrm{kg} / \mathrm{ha}) / \mathrm{yr}]$ \\
pound per year $(\mathrm{lb} / \mathrm{yr})$ & 453.6 & gram per year $(\mathrm{g} / \mathrm{yr})$ \\
square mile $\left(\mathrm{mi}{ }^{2}\right)$ & 2.590 & square kilometer $\left(\mathrm{km}{ }^{2}\right)$ \\
\hline
\end{tabular}

Temperatures can be converted to degrees Celsius $\left({ }^{\circ} \mathrm{C}\right)$ or degrees Fahrenheit $\left({ }^{\circ} \mathrm{F}\right)$ by the equations:

$$
\begin{aligned}
& { }^{0} \mathrm{C}=5 / 9\left({ }^{\circ} \mathrm{F}-32\right), \\
& { }^{0} \mathrm{~F}=9 / 5\left({ }^{\circ} \mathrm{C}\right)+32 .
\end{aligned}
$$

\section{Water-Quality Abbreviations}

(col/acre)/yr

$\mathrm{col} / \mathrm{mL}$

col/100 mL

$\mu \mathrm{m}^{3} / \mathrm{mL}$

$\mu \mathrm{S} / \mathrm{cm}$

NTU colonies per acre per year

colonies per milliliter

colonies per 100 milliliters

cubic micrometer per milliliter

microsiemens per centimeter at 25 degrees Celsius

nephelometric turbidity units

\section{Datums}

Horizontal coordinate information is referenced to the North American Datum of 1983 (NAD 83). Vertical coordinate information is referenced to the North American Vertical Datum of 1988 (NAVD 88). 


\section{Acronyms}

\begin{tabular}{|c|c|}
\hline ANC & acid-neutralizing capacity \\
\hline BMP & best-management practice \\
\hline CA & correspondence analysis \\
\hline Chl & $\begin{array}{l}\text { chlorophyll-a analyzed at U.S. Geological Survey } \\
\text { National Water-Quality Laboratory (Lakewood, } \\
\text { Colorado) by high-performance liquid } \\
\text { chromatography }\end{array}$ \\
\hline ELISA & enzyme-linked immunosorbent assay \\
\hline FLUOR & real-time continuous fluorescence \\
\hline $\mathrm{GC} / \mathrm{MS}$ & gas chromatography/mass spectrometry \\
\hline HPLC & high-performance liquid chromatography \\
\hline ISO & International Standardization Organization \\
\hline KDHE & Kansas Department of Health and Environment \\
\hline $\mathrm{LA}$ & light availability in the mixed layer \\
\hline MCL & Maximum Contaminant Level \\
\hline MIB & 2-methylisoborneol \\
\hline MSE & mean square error \\
\hline NAD 83 & North American Datum of 1983 \\
\hline NAT & nonalgal turbidity \\
\hline NAVD 88 & North American Vertical Datum of 1988 \\
\hline NWQL & National Water-Quality Laboratory \\
\hline $\mathrm{OP}$ & orthophosphate \\
\hline PRESS & prediction error sum of squares \\
\hline PVC & polyvinyl chloride \\
\hline 0 & discharge \\
\hline $\mathrm{R}^{2}$ & coefficient of determination \\
\hline SC & specific conductance \\
\hline SD & Secchi depth \\
\hline SMCL & Secondary Maximum Contaminant Level \\
\hline SSC & suspended-sediment concentration \\
\hline $\mathrm{SS}_{\mathrm{x}}$ & sum of square of errors \\
\hline TIN & total inorganic nitrogen \\
\hline TKN & $\begin{array}{l}\text { total Kjeldahl nitrogen, or total ammonia plus organic } \\
\text { nitrogen }\end{array}$ \\
\hline TMDL & total maximum daily load \\
\hline $\mathrm{TN}$ & total nitrogen \\
\hline TP & total phosphorus \\
\hline TSI & tropic-state index \\
\hline Turb & turbidity \\
\hline USEPA & U.S. Environmental Protection Agency \\
\hline USGS & U.S. Geological Survey \\
\hline WHO & World Health Organization \\
\hline WT & water temperature \\
\hline Zmix & depth of mixed layer \\
\hline
\end{tabular}




\title{
Surface-Water-Quality Conditions and Relation to Taste- and-Odor Occurrences in the Lake Olathe Watershed, Northeast Kansas, 2000-02
}

\author{
By David P. Mau, Andrew C. Ziegler, Stephen D. Porter, and Larry M. Pope
}

\section{Abstract}

Surface water in the Lake Olathe watershed, located in northeast Kansas, was sampled from June 2000 through December 2002 to characterize water-quality conditions in relation to physical properties, major ions, sediment, nutrients, selected trace elements, selected pesticides, fecal indicator bacteria, phytoplankton, and taste-and-odor compounds. In addition, two continuous real-time water-quality monitors were operated-one in Cedar Creek at Highway 56, the main tributary to Lake Olathe, and one in Lake Olathe, a supplemental domestic water supply and recreational resource for the city of Olathe.

Median concentrations of dissolved and total forms of nitrogen and phosphorus in samples from Cedar Creek were larger than in samples from Lake Olathe, indicating that nutrients in the watershed were transported to Lake Olathe by Cedar Creek from June 2000 through December 2002. Increased concentrations of total phosphorus in samples from the hypolimnion of Lake Olathe compared to the epilimnion indicated that release of total phosphorus from bottom sediments occurred in the lake.

Of the 50 pesticides analyzed in water samples from Cedar Creek and Lake Olathe, 10 pesticides were detected at concentrations greater than 0.01 microgram per liter in samples from Cedar Creek, and 9 pesticides were detected at concentrations greater than 0.01 microgram per liter in Lake Olathe, including four herbicides with concentrations exceeding 1.0 microgram per liter. Atrazine was detected at larger concentrations than any other pesticide in samples from both Cedar Creek and Lake Olathe during 2001 and 2002. Concentrations did not exceed the U.S. Environmental Protection Agency drinking-water annual average criterion of 3.0 micrograms per liter; however, concentrations in single samples were larger than 3.0 micrograms per liter.

Regression analysis was used to assist in the estimation of sediment and chemical loads and yields. The estimated mean orthophosphate load for 2001 and 2002 represented 29 percent of the total phosphorus load to Lake Olathe. Estimated yields to Lake Olathe of both total nitrogen and total phosphorus, 13.0 and 1.1 pounds per acre per year, respectively, were consistent with mixed agricultural land use occurring in the watershed.

Concentrations of fecal coliform bacteria samples from Lake Olathe were less than both primary and secondary singlesample criteria for recreational water in Kansas in place at the time of sampling. Sufficient samples were not collected to compare to the December 2003 Kansas Department of Health and Environment criteria, but single-sample Escherichia coli samples collected from Cedar Creek during storm runoff exceeded 2,000 colonies per 100 milliliters of water (former secondary recreation water-quality criterion for fecal coliform bacteria) in four of the seven samples collected.

Water from Cedar Creek and Lake Olathe was analyzed in 2002 by enzyme-linked immunosorbent assay for microcystinLR, a toxic algal compound. Concentrations of microcystin-LR in Lake Olathe during 2002 ranged from less than 0.1 to 0.41 microgram per liter, which is not considered a significant health risk according to guidelines published by the World Health Organization.

Regression models were developed for four taste-and-odor phytoplankton species detected frequently in Lake OlatheMelosira granulata, Anabaena, Oscillatoria, and Cryptomonas. The coefficient of determinations, $\mathrm{R}^{2}$, ranged from 0.64 to 0.89 , and $p$-values ranged from less than 0.001 to 0.014 , indicating a statistically significant relation with lake-residence time, specific conductance, turbidity, Secchi transparency depth, real-time continuous fluorescence, and total ammonia plus organic nitrogen as nitrogen.

Actinomycetes, filamentous bacteria that are known producers of geosmin and 2-methylisoborneol (MIB), were sampled and analyzed in 2002 in water from Cedar Creek and Lake Olathe. In Lake Olathe, actinomycetes concentrations ranged from 4 to 64 colonies per milliliter of water, and geosmin concentrations ranged from less than 5.0 to 12.0 nanograms per liter. MIB was detected once at a concentration of 6.0 nanograms per liter.

A regression model for geosmin, a taste-and-odor compound, was developed in an effort to predict taste-and-odor occurrences. The regression model developed for geosmin used Secchi depth, specific conductance, and turbidity. The coefficient of determination, $\mathrm{R}^{2}$, was 0.70 , and the $p$-value was 0.0016 , which indicated a statistically significant relation. However, the use of Secchi transparency depth in the model 


\section{Surface-Water-Quality Conditions and Relation to Taste-and-Odor Occurrences in the Lake Olathe Watershed, Northeast Kansas, 2000-02}

prevented the development of a similar model using only continuous real-time water-quality sensors operated during the study.

\section{Introduction}

Lake Olathe, located in Johnson County, northeast Kansas, was impounded in 1956 as a domestic water supply for the citizens of Olathe. In addition to providing drinking water, the lake is an important recreational resource (fig. 1). Since impoundment of the lake, drinking water from Lake Olathe has had almost annual taste-and-odor problems (Lee and Sears, 1985). Although the water can be treated to remove taste and odor, the process is expensive and does not address the causes of the problem.

In 2000, the city of Olathe in cooperation with the U.S. Geological Survey (USGS) and with financial and technical support from the Kansas Department of Health and Environment (KDHE) and the U.S. Environmental Protection Agency (USEPA), began an investigation to evaluate the water quality of the Lake Olathe watershed. The goal of the ongoing investigation is to improve understanding of the concentrations of chemicals in stream and lake water and to identify the conditions and processes in the lake and watershed that lead to algal growth and taste-and-odor problems in drinking water from Lake Olathe. The information from this investigation will assist the city of Olathe in developing a comprehensive watershed protection plan and can be used to inform the community of the importance of maintaining and protecting water quality in Lake Olathe.

\section{Purpose and Scope}

The purposes of this report are to: (1) describe the surfacewater-quality conditions in Lake Olathe and the Lake Olathe watershed; (2) evaluate the concentrations and loads in water from Cedar Creek and Lake Olathe for sediment and nutrients (forms of nitrogen and phosphorus) and the concentrations of selected trace elements, selected pesticides, and algal species (phytoplankton); (3) describe the chemical and biological processes that are responsible for taste-and-odor occurrences in drinking water from Lake Olathe; and (4) evaluate the relation of continuous real-time water-quality constituents to selected chemicals and taste-and-odor causing compounds [geosmin, 2methylisoborneol (MIB)] associated with algae. The investigation included selected seasonal and varying hydrologic condition water-quality sampling of both Cedar Creek and Lake Olathe from June 2000 through December 2002. Continuous real-time water-quality instruments were placed in Cedar Creek and Lake Olathe and operated from October 1, 2000, through December 31, 2002.

The report provides estimates of loading of sediment, nutrients, and other selected chemicals to Lake Olathe. Additionally, the water-quality sampling of Cedar Creek described in this report documents the contributions of Cedar
Creek to taste-and-odor occurrences. The information can be used by the city of Olathe managers to understand sources of chemicals to Lake Olathe.

Results of water-quality sampling and approaches described in this report may be used by the USGS and other government agencies to improve understanding of the chemical inputs to lakes that are responsible for algal blooms and related taste-and-odor occurrences in the water. The results from this study also will support Federal, State, and local goals toward implementing watershed strategies to improve water quality. The results also may be used by various government agencies to establish total maximum daily loads (TMDLs) and to evaluate best-management practices (BMPs) designed to mitigate nonpoint-source pollution. In addition, information from this report can be used to develop statistical models using continuous real-time monitoring data to better predict tasteand-odor occurrences.

\section{Description of Lake Olathe Watershed}

The total area of the Lake Olathe watershed is $16.9 \mathrm{mi}^{2}$ $(10,800$ acres) and encompasses the drainage areas of Cedar Lake and Lake Olathe as well as Cedar Creek, the main tributary joining the two lakes (fig. 1). Cedar Lake has a surface area of about 54 acres and a 2000 storage volume of 334 acre-ft at the dam crest elevation of $1,001.0 \mathrm{ft}$ above the NAVD 88 (fig. 1) (Mau, 2002). Lake Olathe has a surface area of about 170 acres and a 2000 storage volume of 3,100 acre-ft at the dam crest elevation of $937.5 \mathrm{ft}$ above the NAVD 88. The physical characteristics of Cedar Lake and Lake Olathe are summarized in table 1 .

There are approximately 1,000 people in the watershed, most of whom live in single-family residences and farms in the area (C. Adams, city of Olathe, written commun., 2001). Lake Olathe is located within the Olathe city limits [population of 102,000 in 2002 (Olathe Chamber of Commerce, 2002)], the only city in the watershed. A public 18-hole golf course abuts Lake Olathe on the east side of the reservoir.

The mean annual temperature in Olathe, Kansas, is about $55^{\circ} \mathrm{F}$, with a mean monthly range of $29^{\circ} \mathrm{F}$ in January to $79^{\circ} \mathrm{F}$ in July (National Oceanic and Atmospheric Administration, 1973-2002). Mean annual precipitation (1973-2002) is about 40 in., which occurs primarily during the growing season from April through September (National Oceanic and Atmospheric Administration, 1973-2002).

The Lake Olathe watershed is underlain by sedimentary bedrock deposited during late Pennsylvanian time (about 285 to 320 million years ago) (Lee and Sears, 1985). The bedrock is mostly shale, with some prominent limestone layers and sandstone. Pre-Illinoian glacial till and a thin lens of loess (windblown Pleistocene deposits) cover the bedrock. Soils in the watershed were formed from windblown loess, glacial outwash, and residuals derived from the weathering of shale and limestone bedrock (Lee and Sears, 1985). 

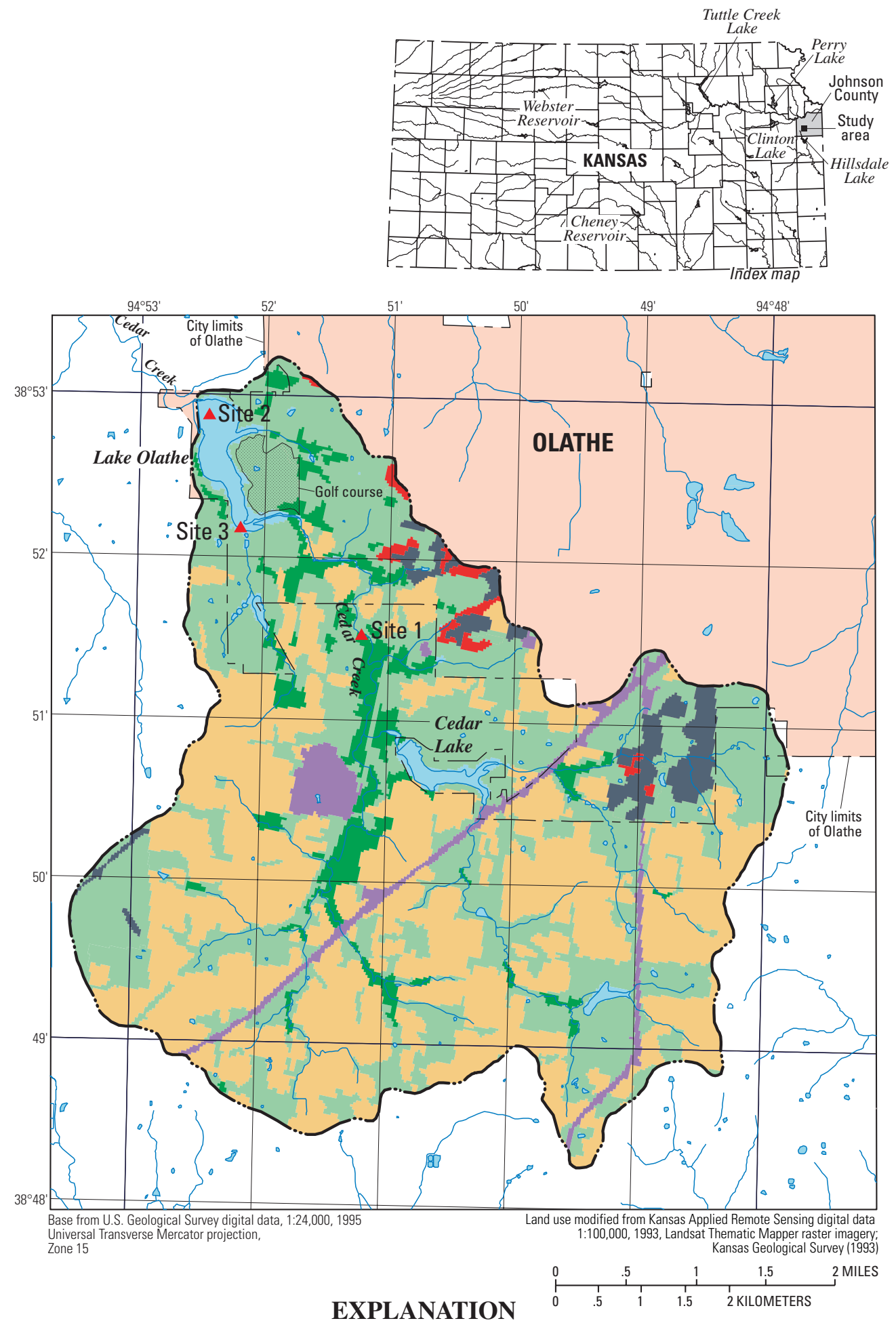

Land use in Lake Olathe watershed
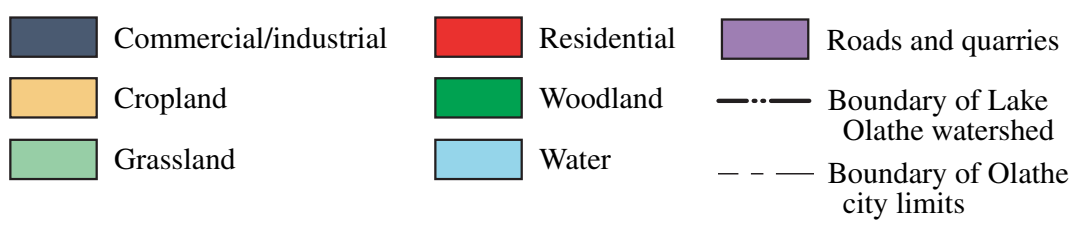

Site 1

- Water-quality sampling site and number

Figure 1. Location of Lake Olathe watershed in northeast Kansas, water-quality sampling sites, and land use. 


\section{Surface-Water-Quality Conditions and Relation to Taste-and-Odor Occurrences in the Lake Olathe Watershed, Northeast Kansas, 2000-02}

Table 1. Physical characteristics of Cedar Lake and Lake Olathe near Olathe, northeast Kansas.

[--, not applicable]

\begin{tabular}{lcc}
\hline \multicolumn{1}{c}{ Characteristic (unit of measurement) } & Cedar Lake & Lake Olathe \\
\hline Total storage volume at dam crest elevation (acre-feet), 2000 & 334 & 3,100 \\
Surface area (acres) & 54 & 170 \\
Mean depth (feet) & 6.20 & 18.2 \\
Maximum depth (feet) & 14.0 & 44.0 \\
Mean annual inflow (cubic feet per second) & -- & 15.6 \\
Drainage area of watershed (square miles) & 6.10 & 10.8 \\
\hline
\end{tabular}

Land use in the Lake Olathe watershed is primarily agricultural cropland and grassland, which represents 83 percent of the watershed (fig. 1) (Kansas Geological Survey, 1993). Cropproduction statistics were not available for the Lake Olathe watershed; therefore, the following statistics were based on figures for Johnson County where the watershed is located (fig. 1, index map). Crop production in the county has declined from 108,000 acres of harvested cropland in 1960 to 71,000 acres of harvested cropland in 2000 (Kansas State Board of Agriculture and U.S. Department of Agriculture, 1960-95; Kansas Department of Agriculture and U.S. Department of Agriculture, 1996-2000). Crop production of wheat, rye, corn, oats, and sorghum declined between 1960 and 1999. However, soybean and all hay production increased during the same period. Residential and commercial land use in Johnson County has increased during the 40-year period 1960-99, and similar residential and commercial growth is evident in the Lake Olathe watershed, from 2.0 percent of the watershed in 1985 to 15 percent in 1999 (Lee and Sears, 1985; K. Dobbs, Kansas Biological Survey, written commun., 2001).

Livestock production in Johnson County has been relatively stable for cattle and calves; however, annual inventories of hogs, sheep and lambs, and chickens have declined (Kansas State Board of Agriculture and U.S. Department of Agriculture, 1960-95; Kansas Department of Agriculture and U.S. Department of Agriculture, 1996-2000).

\section{Previous Investigations}

Rapid urbanization and the potential effects on water quality in the Lake Olathe watershed led the city of Olathe to conduct a study of Lake Olathe in 1982 to determine the relation between nutrient loads and eutrophication (nutrient enrichment). The study was done with support from the USEPA Clean Lakes Program under Section 314-A of the Federal Clean Water Act of 1972. The 13-month study (1982-83) examined the limnology and water quality of the reservoir, estimated nutrient loads to the reservoir as well as sources of nutrients in the watershed, and projected nutrient loads in the year 2000. Recommendations were made toward management and long-term monitoring of the reservoir and watershed (Lee and
Sears, 1985). During the 1982-83 study, the population for the city of Olathe was about 46,500 (Lee and Sears, 1985).

On the basis of a 1983 bathymetric survey and comparison to historical topographic maps, the 1982-83 study showed sediment deposition in Lake Olathe since 1956 to be about 16 acreft. Sediment loads to Lake Olathe were estimated to be about 23.6 million lb/yr and did not include trapping of sediment in the more than 60 small impoundments in the watershed. Phosphorus loads calculated from water samples and estimates of streamflow were estimated to be $1,450 \mathrm{lb} / \mathrm{yr}$ and expected to increase to $1,850 \mathrm{lb} / \mathrm{yr}$ by the year 2000 because of anticipated increased urbanization (Lee and Sears, 1985).

Tissue from channel catfish and other predator fish species were analyzed during the 1982-83 study for selected trace elements and pesticides, and detectable concentrations of these constituents were found. However, reservoir bottom sediment was not analyzed, and water-quality analysis was limited to nutrients and algal determinations. The 1982-83 study concluded by recommending a future, phase-two monitoring effort to include comprehensive reservoir water-quality sampling during the summer months at multiple locations and depths.

The U.S. Army Corps of Engineers, in cooperation with the Kansas Water Office, did bathymetric surveys in 2000 for 23 small municipal lakes in Kansas, including Lake Olathe. The total sediment deposition to Lake Olathe on the basis of that investigation, from 1956 to 2000, was 30 acre-ft, or 0.67 acre-ft of sediment deposition per year (Kansas Water Office, 2001, p. 31).

In response to concerns of rapid sedimentation rates reducing the storage capacity and the quality of water in Lake Olathe, the USGS began a cooperative investigation with the city of Olathe, KDHE, and USEPA in 2000 (Mau, 2002). The purpose of the 2000 investigation was to provide a complete lake and watershed assessment of the Lake Olathe watershed. One of the objectives of the 2000 investigation was to identify trends in concentrations of selected water-quality constituents. Through chemical analysis and dating of sediment cores, both baseline conditions and trends in water-quality constituents were determined to help identify the effects of land use on receiving water bodies as well as to help document the effectiveness of landmanagement practices.

By 2000, approximately 338 acre-ft of sediment deposition had occurred in Cedar Lake since dam closure in 1938, and 
317 acre-ft had occurred in Lake Olathe since 1956. Mean annual sediment deposition was 5.45 acre-ft, or 0.89 acre- $\mathrm{ft} / \mathrm{mi}^{2}$ for Cedar Lake, and 7.0 acre-ft, or $0.42 \mathrm{acre}-\mathrm{ft} / \mathrm{mi}^{2}$ for Lake Olathe. Mean annual sediment loads for the two reservoirs were 9.6 million $\mathrm{lb}$ for Cedar Lake and 12.6 million $\mathrm{lb}$ for Lake Olathe (Mau, 2002).

The 2000 investigation also determined the mass transport of various constituents to Cedar Lake and Lake Olathe that can be useful in the establishment of TMDLs. On the basis of calculations from deposited sediment in each reservoir, mean annual phosphorus loads to Cedar Lake and Lake Olathe were estimated to be 14,700 and $9,720 \mathrm{lb}$, respectively. The mean annual phosphorus yields to Cedar Lake were estimated to be $3.74 \mathrm{lb} /$ acre and $0.91 \mathrm{lb} / \mathrm{acre}$ to Lake Olathe (Mau, 2002).

During the 2000 investigation, reservoir-bottom sediment from Cedar Lake and Lake Olathe was analyzed for selected pesticides including organochlorine and organophosphate insecticides, acetanilide, and triazine herbicides.

Organochlorine and organophosphate insecticides were not detected in bottom-sediment samples from either Cedar Lake or Lake Olathe, but the acetanilide herbicides alachlor and metolachlor, and the triazine herbicide, atrazine, were detected in sediment from both reservoirs (Mau, 2002).

The diatoms (microscopic, single-celled organisms) Cyclotella bodanica, an indicator of low organic-enriched water, and Cyclotella meneghiniana, an indicator of organicenriched water, were both present in sediment cores from Lake Olathe (Mau, 2002). The presence of both of these diatoms suggests varying periods of low and high eutrophication in Lake Olathe from 1956 to 2000.

\section{Acknowledgments}

The authors thank Ms. Carly Adams with the city of Olathe for her assistance in obtaining reference material and other study needs. The authors also thank Patrick Finnegan, Melinda Yager, Lee Kellenberger, and Stacy Rosner of the USGS (Lawrence, Kansas) for their help in onsite work and datacollection efforts. Additionally, the authors appreciate the editorial reviews of Lanna Combs to enhance the readability of the report.

\section{Methods}

Streamflow, suspended-sediment, and water-quality data were collected from Cedar Creek at Highway 56 in Olathe, Kansas, from June 2000 through December 2002 (site 1, fig. 1). Suspended-sediment and water-quality data were collected from two locations at Lake Olathe from June 2000 through December 2002; one sampling site was near the dam at the intake structure (site 2, fig. 1), and one sampling site was located at the upstream end of the lake (site 3, fig. 1). The water-quality sampling sites at Cedar Creek at Highway 56 and at the upstream end of Lake Olathe were chosen to characterize water-quality conditions from the inflow to the lake and in the upper section of the lake. The intake structure was chosen as a water-quality sampling site because lake water is removed at this location, treated, and used to supplement the city's drinking-water supply. The data collected seasonally and under varying hydrologic conditions from these sampling sites were used to characterize water-quality conditions in the lake and watershed, and to estimate chemical loads during periods of base flow and runoff. Base flow was defined in this study as streamflow unaffected by storm runoff.

\section{Onsite Measurements}

Physical properties were measured in water from each of the three sampling sites (fig. 1) during 2000-02. Measurements were made at the time of sample collection and included specific conductance, $\mathrm{pH}$, water temperature, turbidity, dissolved oxygen, fluorescence, and alkalinity. Measurements for these constituents, except alkalinity, were made using a YSI 6600 multiparameter instrument calibrated prior to sampling on the basis of methods described in Wagner and others (2000). Alkalinity was measured using an incremental titration method. During sampling periods in Lake Olathe, the multiparameter instrument was used to measure physical properties at each sampling site from the water surface to the bottom of the lake in 2 -ft increments.

A continuously recording YSI 6600 multiparameter instrument (fig. 2) was installed in July 2000 in Cedar Creek at Highway 56, Olathe, Kansas (site 1), and in Lake Olathe near the dam (site 2). The multiparameter instrument installed in Lake Olathe near the dam (site 2) was adjusted and maintained at $10 \mathrm{ft}$ below the water surface near the water-supply intake. Water-quality parameters measured at these sites from October 1, 2000, through December 31, 2002, included specific conductance, $\mathrm{pH}$, water temperature, turbidity, dissolved oxygen, and fluorescence as a measure of total chlorophyll. Specifications for the YSI multiparameter monitor are presented in table 22 in the "Supplemental Information" section of this report. Turbidity measurements, a measure of water clarity, for this study were made with a YSI 6026 sensor that conforms to International Standardization Organization (ISO) Method 7027 (International Standardization Organization, 1999). Turbidity values from other turbidity sensors may not be comparable to turbidity values used in this report (Sadar, 2002; Ziegler, 2002). The water-quality monitors were inspected onsite by USGS personnel approximately monthly to maintain calibration. Guidelines and standard procedures for maintaining the waterquality monitors are described in Wagner and others (2000).

In addition, water-level data in Cedar Creek and Lake Olathe were recorded at 15-minute intervals using pressure transducers. Streamflow measurements were made to establish and maintain the relation between stage and discharge at the Cedar Creek site (Buchanan and Somers, 1969; Kennedy, 1984). Water-level readings were transmitted every 4 hours by 


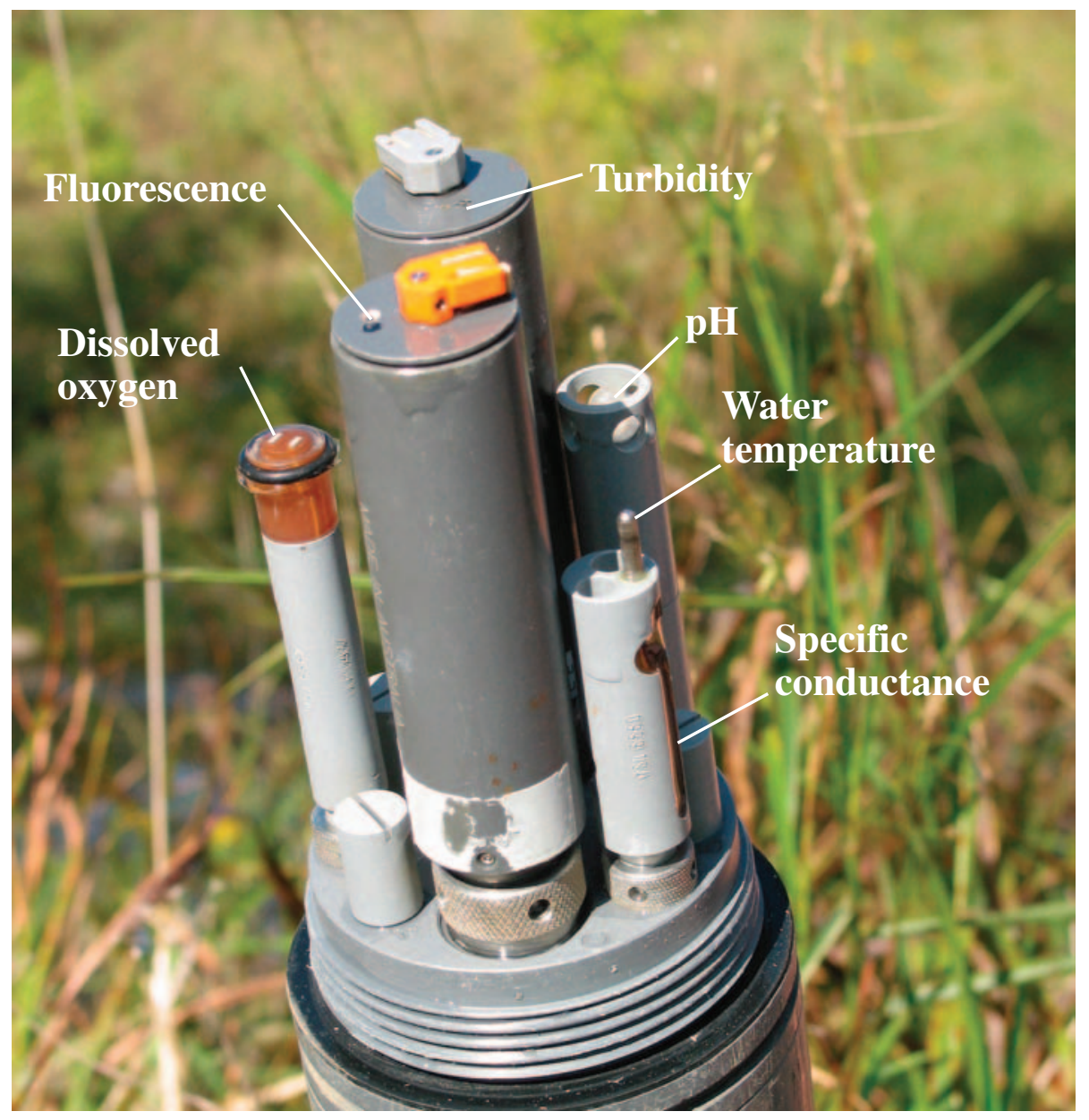

Figure 2. Multiparameter monitor used to measure specific conductance, $\mathrm{pH}$, water temperature, turbidity, dossolved oxygen, and fluorescence in water during sample collection and for in-stream and in-lake continuous monitoring.

satellite to the USGS office in Lawrence, Kansas, and were made available in real time on the World Wide Web (http://ks.water.usgs.gov/Kansas/rtqw/ and http://waterdata.usgs.gov/ks/nwis/).

\section{Sample Collection}

Water samples were collected seasonally and under varying hydrologic conditions from one inflow site on Cedar Creek (site 1) and two lake sites (sites 2 and 3) (fig. 1) and analyzed for concentrations of suspended sediment, major ions, nutrients, trace metals, and selected pesticides. Samples were collected manually using depth- and width-integrated methods described by Edwards and Glysson (1988) and Wilde and Radke (1998). Water samples were analyzed for suspended-sediment concentration at the USGS sediment laboratory in Iowa City, Iowa, according to methods presented in Guy (1969).

Chemical concentrations may vary depending on whether sampling occurs during runoff, during periods of low flow, or different times of the year. To define this variability, samples were collected seasonally and under varying hydrologic conditions. Water samples were collected from Cedar Creek at 10 equal-width increment locations along a transect. The creek samples were composited in either a 14-L polyethylene churn or stainless-steel canister and transported to the USGS office in Lawrence, Kansas, for processing within 2 hours of collection. Water samples were collected from the deeper areas in Lake Olathe using Teflon tubing and a peristaltic pump and from the lake surface by dipping a stainless-steel canister into the lake or using a depth-integrated vertical sampler consisting of 2-in. outside-diameter polyvinyl chloride (PVC) pipe with a check valve that came in 6-ft lengths that were expandable to $18 \mathrm{ft}$. The lake samples were composited in either a 14-L polyethylene churn or stainless-steel canister and transported to the USGS office in Lawrence, Kansas, for processing.

Samples for bacteria analysis were collected at the Cedar Creek inflow site (site 1) in sterile 1-L bottles from the center of flow in the stream. Samples were chilled and processed within 6 hours of collection using methods described by Myers and Wilde (1999). 
One estimate of trophic state is chlorophyll- $a$, the primary pigment in phytoplankton that produces chemical energy. However, chlorophyll- $a$ should only be considered as an approximation of the true algal biomass because chlorophyll- $a$ concentrations can be affected by other environmental factors and analytical methods (Britton and Greeson, 1989). In this study, a fluorometric probe was installed on the real-time waterquality instrument and used as a surrogate to continuously measure chlorophyll- $a$, although it is understood that fluorometric probes cannot differentiate among chlorophyll- $a, b$, and $c$. In addition to chlorophyll- $a$, the fluorometric probe also may be measuring unidentified inorganic and organic fluorescing material. Although there was no evident relation in Lake Olathe between chlorophyll- $a$ concentrations analyzed using highperformance liquid chromatography (HPLC) and a real-time continuous fluorometric probe (fig. 3), the parameters measured by the fluorometric probe were statistically significant in the development of regression models for orthophosphate and Cryptomonas, a taste-and-odor related species of phytoplankton. Measurements made using the fluorometer will be referred to in this study as real-time continuous fluorescence and will be used in analyses requiring chlorophyll- $a$ concentrations.

Water samples used for analysis of phytoplankton enumeration and abundance, geosmin, and MIB were collected manually from Cedar Creek and the two lake sites (fig. 1). Samples were collected using depth- and width-integrated methods described by Edwards and Glysson (1988) and Wilde and others (1999).

\section{Laboratory Methods}

Water samples from all three sites were analyzed at the USGS National Water-Quality Laboratory (NWQL) in Denver, Colorado, for major ions, nutrients, selected trace elements, and selected pesticides . Analytical methods, reporting limits, and detection levels are presented in tables 23 and 24 (in "Supplemental Information" section of this report). The reporting limit is the laboratory reportable corrected concentration that accounts for nontargeted compounds that can interfere with the sample analysis. The detection level is the smallest concentration that can be reported under ideal conditions.

An additional analysis of water samples for atrazine, a preand post-emergent herbicide used in the production of corn, grain sorghum, and other plants, was done using enzyme-linked immunosorbent assay (ELISA) and verified using gas chromatography/mass spectrometry (GC/MS) (Zaugg and others, 1995). The ELISA and GC/MS analyses were done at the USGS Organic Geochemistry Research Laboratory in Lawrence, Kansas. Atrazine concentrations were determined using a commercially available competitive ELISA (Abraxis LLC, Hatboro, Pennsylvania). ELISA is a method of analysis that relies on specific interactions between antibodies and antigens (analytes). A colorimetric response is produced and measured using a spectrophotometer and compared with a calibration curve that is run with each assay. The method reporting limit is $0.10 \mu \mathrm{g} / \mathrm{L}$ (Bushway and others, 1988). The atrazine assay detected atrazine and related triazine compounds to

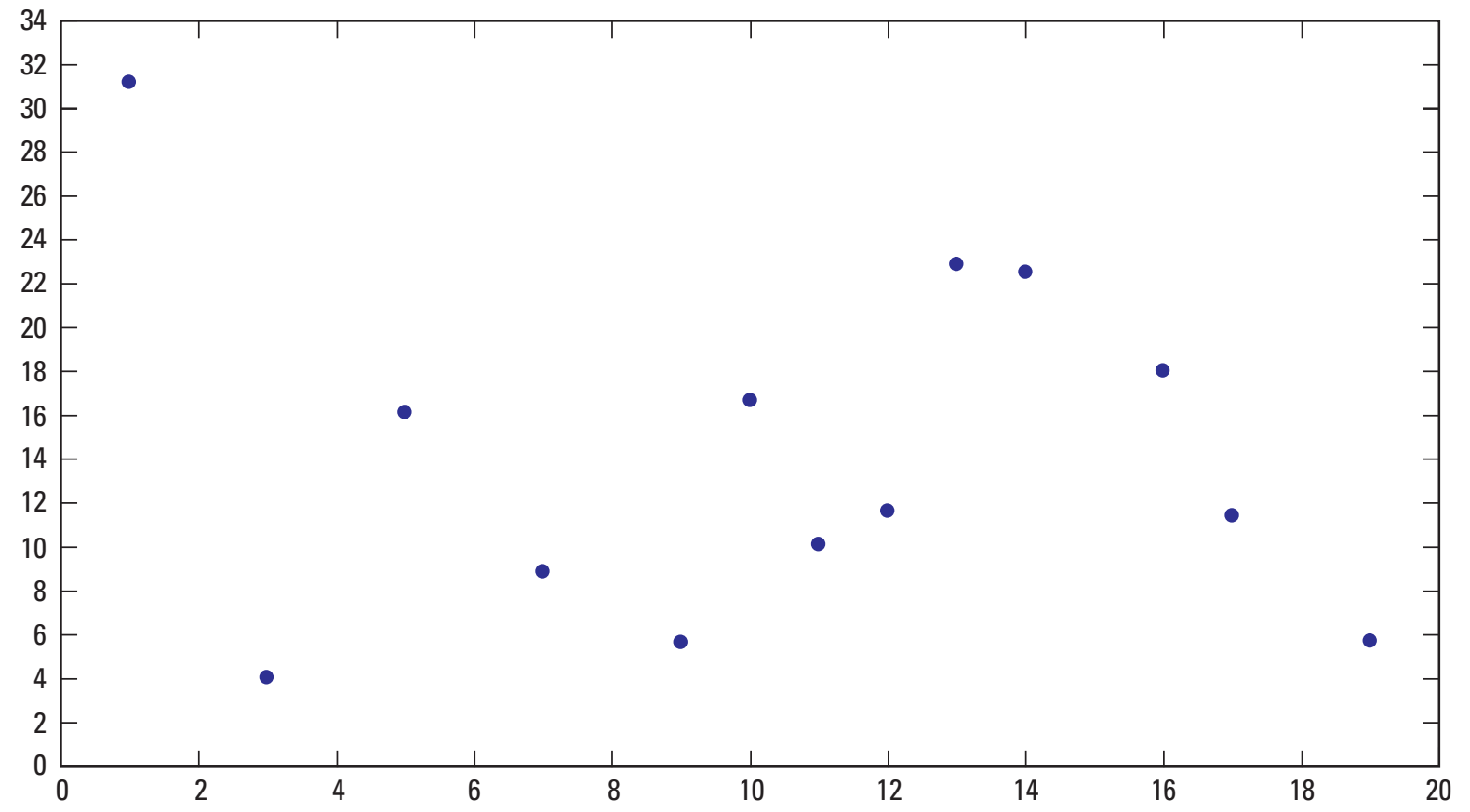

Chlorophyll-a concentration analyzed using high-performance liquid chromatography (HPLC), in micrograms per liter

Figure 3. Concentrations of chlorophyll- $a$ in water samples analyzed using high-performance liquid chromatography in relation to concentrations analyzed using a continuous real-time fluorometer in Lake Olathe near dam (site 2), 2001-02. 


\section{Surface-Water-Quality Conditions and Relation to Taste-and-Odor Occurrences in the Lake Olathe Watershed, Northeast Kansas, 2000-02}

different degrees. Therefore, a subset of samples was analyzed using more specific GC/MS to confirm the ELISA results.

The membrane filter technique was used for bacteria analysis, although this method may underestimate the number of viable coliform bacteria (Eaton and others, 1995). For ideal counts of fecal coliform, the 95-percent confidence interval for the lower limit of the ideal range is 20 to 60 colonies with corresponding confidence-interval widths of \pm 9 to \pm 15 colonies (or \pm 25 to 45 percent) (Rasmussen and Ziegler, 2003). Ideal plate counts for Escherichia coli (E. coli) range from 20 to 80 colonies with corresponding confidence interval widths ranging from \pm 9 to \pm 18 colonies. Bacteria densities calculated on the basis of counts outside of these ranges were considered nonideal counts. Ideal and nonideal counts were used during analysis of bacteria data.

Phytoplankton samples were identified and enumerated by BSA Environmental Services, Beachwood, Ohio, using a Leica inverted compound microscope with 150X, 300X, 600X, and $1,000 \mathrm{X}$ objectives and epifluorescence. The magnification used depended on the size of the dominant taxa and the size and number of particulates. The goal was to count at multiple magnifications to correctly enumerate and identify taxa present that varied in size by several orders of magnitude. If the sample was dominated by cells or natural units less than 10 to $20 \mu \mathrm{m}$ or if the cells were fragile and difficult to identify, the majority of counting was completed at $600 \mathrm{X}$ to $1,000 \mathrm{X}$ magnification.

Natural units enumerated included single cells, filaments, or colonies. The abundance of all phytoplankton taxa was calculated as cells per liter and then multiplied by the biovolume for one cell of that species. The abundance of common taxa was estimated by random field counts. The goal, regardless of magnification, was to enumerate and identify a minimum of 400 natural units per sample exclusive of miscellaneous microflagellates. Extremely sparse samples or samples with high particulates yielded less than 400 natural units. For samples with common colonies or filaments, the counts included several thousand cells because total cell numbers of multicell units (colonies, filaments) were quantified. In accord with Lund and others (1958), the data were accurate to within 90-percent confidence limits.

Microcystis is a cyanobacteria (blue-green algae) genus that includes both toxic and nontoxic members. Toxic cyanobacteria blooms are an emerging issue in the United States and the world because of increased source-water nutrient pollution caused by eutrophication. Toxic Microcystis populations can synthesize microcystin, a hepatotoxin that can cause health concerns when it occurs in drinking water or recreational reservoirs. Analysis of microcystin was done using an ELISA method. The analysis was done at the USGS Organic Geochemistry Research Laboratory in Lawrence, Kansas. Microcystin concentrations were determined using a commercially available ELISA (Abraxis LLC, Hatboro, Pennsylvania). The method reporting limit was $0.10 \mu \mathrm{g} / \mathrm{L}$.

Actinomycetes, a bacteria that is typically filamentous and can cause an earthy smell in drinking water and "muddy" tastes in fish, were enumerated to assess water quality in Lake Olathe.
Actinomycetes occur in most soils, usually in the top 6 to $12 \mathrm{in}$., where most of the materials exist that support their life. They are an essential part of plant growth cycles as they are the primary decomposers of tough plant-tissue residues such as tree bark, wood-pulp type materials, and plant stems. The earthy smell of soil is caused by the presence of actinomycetes. Geosmin and MIB also have been isolated from actinomycetes, and researchers have shown that actinomycetes produce a variety of odorous compounds, including those that smell woody and like a potato bin (Gerber and Lechavalier, 1965;

Gerber, 1969). The analysis of actinomycetes was done by the USGS Microbiological Laboratory in Columbus, Ohio, using a double-layer agar-plating method described in Eaton and others (1995).

Analytical quality control of phytoplankton enumeration and identification consisted of replicate analysis of samples. Chlorophyll- $a$ and $b$ were determined by NWQL using highperformance liquid chromatography (HPLC) methods as described in Britton and Greeson (1989).

Geosmin and MIB were analyzed using gas chromatography (GC) (Zimmerman and others, 2002). The analysis was done at the USGS Organic Geochemistry Research Laboratory in Lawrence, Kansas, and replicate analysis was done by MWH Laboratories, Monrovia, California, a contract laboratory to the city of Olathe, Kansas. The method was suitable for the determination of nanogram-per-liter concentrations of geosmin and MIB in filtered, natural water samples. Suspended particulate matter was removed from the samples by filtration, so the method measured only dissolved-phase compounds. Qualitycontrol practices included evaluation of laboratory blank and spiked samples, instrument performance, and corrective actions. Compounds eluting from the GC column were identified by comparing their measured ions and retention times to reference ions and retention times obtained by the measurement of spiked control samples analyzed under the same conditions used for the water samples. The method reporting limit for both compounds was $5.0 \mathrm{ng} / \mathrm{L}$. The upper reporting limit was $100 \mathrm{ng} / \mathrm{L}$ without dilution.

\section{Statistical Methods}

Regression models were developed using S-Plus Statistical Software (MathSoft, Inc., 1999) to describe relations between water-quality results from discrete, manually collected samples and the continuously recorded water-quality sensor measurements (specific conductance, $\mathrm{pH}$, temperature, turbidity, dissolved oxygen, and fluorescence as a measure of total chlorophyll), streamflow, suspended-sediment concentration, and time. S-Plus will not generate regression models if there are missing data for any constituents being modeled. Therefore, for some constituents in this study, the number of samples used in the model may be less than the number of samples available. Site-specific regression models were developed using plots of each possible explanatory variable against the response variable and visually examining the plots of the residuals for patterns. 
Explanatory and response variables (except time) were log transformed, if necessary, to remove nonlinearity in the data. A residence-time parameter also was used as an explanatory variable in developing regression models for Lake Olathe. The residence time was defined in this study as the number of continuous days prior to sampling that the elevation of Lake Olathe was below the spillway elevation of $937.5 \mathrm{ft}$. Lake Olathe mean daily elevation data are presented in Putnam and others (2002), and Putnam and Schneider (2003).

An overall model-building method was used (Helsel and Hirsch, 1992, p. 312-314). Generally, if there were several acceptable models ( $\mathrm{p}$-value less than 0.05), the one with the lowest prediction error sum of squares (PRESS) statistic was chosen. A p-value of 0.05 indicates a 95-percent confidence that the data sets being compared are different. PRESS is one of the best measures of the goodness of fit of a regression model (Helsel and Hirsch, 1992, p. 248). Explanatory variables were included in a model only if there was a physical basis or explanation for their inclusion. For variables that were log transformed, retransformation of regression-estimated concentrations was necessary. However, retransformation can cause an underestimation of chemical loads when adding individual load estimates over a long period of time. A Duan's bias correction factor or smear factor (Duan, 1983) was applied to the annual load calculation to correct for this underestimation.

Cohn and others (1989), and Hirsch and others (1993) provide additional information on interpreting the results of regression-based load estimates. Uncertainty of the estimates for regression models was determined using 90-percent prediction intervals (Helsel and Hirsch, 1992). Probabilities of exceeding water-quality standards, recommended criteria, or guidelines of the State of Kansas and USEPA also were determined. Regression methods are described in Helsel and Hirsch (1992), Hirsch and others (1993), Christensen and others (2000), and Rasmussen and Ziegler (2003).

The t-statistic also was evaluated and is a measure of the significance of the coefficients, and therefore of the variables, in the regression equations. Coefficients in the equations that have an absolute t-statistic larger than 2.0 are considered significant and indicate a statistically significant relation to a constituent concentration (Journey and Gill, 2001, p. 32). Correspondence analysis (CA), a statistical procedure to uncover the underlying structure of a relatively large set of variables, was done for phytoplankton data from Lake Olathe to show how samples are grouped solely on the basis of differences in the relative biovolume of species among samples and how species are grouped in relation to their occurrence in samples (Davis, 1986).

Although continuous water-quality monitors can readily measure in-lake physical characteristics such as $\mathrm{pH}$, water temperature, and turbidity, sources of taste-and-odor compounds can only be estimated on a continuous basis using regression analysis because specific probes for direct detection of these sources are not available. Statistical models were developed for selected phytoplankton species that may contribute to taste-andodor occurrences in Lake Olathe as well as for geosmin, a frequently detected taste-and-odor compound. Statistical models were not developed for MIB because of infrequent detections.

\section{Calculation of Loads and Yields}

Concentration values are important measures used to evaluate water-quality criteria; however, regulatory and resource managers also need load-estimate information. A chemical load is the chemical concentration multiplied by streamflow and an appropriate conversion factor, and provides an estimate of the mass of that chemical transported past a given site during a given time. Regulatory authorities may use load estimates to develop TMDLs or evaluate trends, which can be used to compare land use and other factors affecting water quality.

Estimates of yields also are important to resource managers. A yield is defined as an area-normalized load, or simply, the chemical load divided by the drainage area. Yields allow comparison of sites with different drainage areas and can be used to help assess and prioritize land-management practices within or among basins.

Annual and seasonal suspended-sediment, nutrient, atrazine, and bacteria loads were estimated for the Lake Olathe watershed using regression methods. Loads were computed from regression-estimated concentration, stream discharge, and a conversion factor. Nutrient loading is a measure of potential reservoir productivity, or the rate of biomass formation, which will be discussed in the section "Suspended Sediment and Nutrient Loads and Yields in Cedar Creek and Lake Olathe" of this report. Nutrient yields were calculated on the basis of estimated loads to allow comparison among other watersheds in Kansas. Load and yield estimates for complete calendar years 2001 and 2002 were evaluated in this study and are presented in this report.

Estimates of loads and yields for the Lake Olathe watershed were calculated from regression-estimated water-quality constituent concentrations, stream discharge, and appropriate unit conversion factors for the streamgage located on Cedar Creek at Highway 56 (site 1, fig. 1). The contributing-drainage area for this site is $7.54 \mathrm{mi}^{2}$ (4,224 acres) and does not include Cedar Lake or the drainage area of Cedar Lake. The decision to exclude these areas (total of $6.10 \mathrm{mi}^{2}$; table 1) was made on the basis of knowledge that Cedar Lake serves as a substantial sediment trap and runoff-retention structure for its watershed.

Therefore, the inclusion of this area in the calculation of waterquality constituent yields would have produced unrealistically small values for areas of the Lake Olathe watershed contributing the vast majority of constituent loads to Lake Olathe.

For the purpose of the investigation described in this report, the contributing-drainage area to Lake Olathe is $10.8 \mathrm{mi}^{2}$ $(6,912$ acres; table 1$)$ - total drainage area of $16.9 \mathrm{mi}^{2}$ $\left(10,800\right.$ acres) less the Cedar Lake drainage area of $6.10 \mathrm{mi}^{2}$ (3,904 acres). Total water-quality constituent loads (in pounds) to Lake Olathe were estimated by multiplying the calculated yields (in pounds per acre; lb/acre) for the contributing- 


\section{Surface-Water-Quality Conditions and Relation to Taste-and-Odor Occurrences in the Lake Olathe Watershed, Northeast Kansas, 2000-02}

drainage area to the Cedar Creek streamgaging site (site 1, fig. 1) by the total contributing-drainage area (6,912 acres) for Lake Olathe. The underlying assumption for this loadestimation technique is that the water-quality constituent load response for the ungaged $3.26-\mathrm{mi}^{2}(2,088$-acre) area downstream from site 1 is the same as that from the contributing-drainage area to site 1 .

Loads in Cedar Creek for both total Kjeldahl nitrogen (TKN) and total phosphorus (TP) were determined through regression analysis using sample results of TKN and TP as response variables ( $y$ value) and continuous turbidity measurements as the explanatory variable ( $x$ value). TKN was defined in this study as the sum of total ammonia plus total organic nitrogen. These equations were used to estimate hourly concentration values, which then were multiplied by the stream discharge to determine loads. The hourly values were summed seasonally and for each year to produce load estimates. The total nutrient load to Lake Olathe in this study was the sum of the estimated loads for TKN, total inorganic nitrogen, which includes total nitrite plus total nitrate as nitrogen (TIN), orthophosphate (OP), and TP.

\section{Quality Control}

Quality-control samples were routinely collected and analyzed to identify, quantify, and document bias and variability in the collection and processing of data. Sample processing was done primarily at the USGS office in Lawrence, Kansas; therefore, equipment blanks were collected to measure the environmental conditions in the laboratory, and rinse blanks were collected to measure the effectiveness of the equipment cleaning protocols in the laboratory. Quality-control samples were submitted to the NWQL for analysis. Blank samples analyzed for inorganic constituents were prepared with inorganic grade water from the USGS Ocala (Florida) Field Services Unit where this water is quality assured for suitability in the testing of equipment and sampling. Blank samples analyzed for pesticides were prepared with pesticide-grade water obtained from the NWQL in Denver, Colorado. In addition to blank samples, several sequential replicate samples were collected to assess the variability among samples resulting from collection, processing, shipping, and laboratory procedures conducted at different sampling times (Wilde and others, 1999).

Results from equipment and rinse blanks indicated that the USGS laboratory in Lawrence, Kansas, was free of contaminants and that equipment cleaning procedures were good (table 25, in "Supplemental Information" section of this report). However, boron was detected in both an equipment and rinse blank in 2000. Quality-assurance samples in subsequent years did not detect boron greater than the detection level. Small concentrations of chloride $(0.55 \mathrm{mg} / \mathrm{L})$ were identified in an equipment blank in 2001, and small concentrations of manganese $(0.21 \mu \mathrm{g} / \mathrm{L})$ were identified in an equipment blank in 2002 . Concentrations of boron, chloride, and manganese in Lake Olathe in December 2000 were about $93 \mu \mathrm{g} / \mathrm{L}, 48 \mathrm{mg} / \mathrm{L}$, and
$266 \mu \mathrm{g} / \mathrm{L}$, respectively (information on file at USGS office in Lawrence, Kansas). Aside from boron, sample integrity was minimally affected by the detections in the blank samples. Boron and chloride were not detected in equipment blanks in 2002.

Relative percentage differences in sequential replicate samples varied from 0 to about 73 percent, depending on the constituent (table 26, in "Supplemental Information" section of this report). Relative percentage difference was calculated as the difference between the replicate and original sample concentrations divided by the average of the two values, multiplied by 100 . Small differences between the environmental sample and the replicate sample of constituents, for example total phosphorus in a water sample from Lake Olathe on June 27, 2001 (0.04 and $0.06 \mathrm{mg} / \mathrm{L}$, respectively) (table 26, in "Supplemental Information" section of this report), resulted in a large percentage difference, but the magnitude of the difference was within 10 percent for most constituents.

\section{Surface-Water-Quality Conditions}

Surface-water-quality conditions described in this report include water chemistry and selected constituent loads and yields. Phytoplankton characteristics also are described.

\section{Water Chemistry of Cedar Creek and Lake Olathe}

This section presents the results of approximately 2.5 years of water-sample collection at three sites in the Lake Olathe watershed. Factors affecting water quality to be discussed in this section include physical properties such as specific conductance, $\mathrm{pH}$, water temperature, turbidity, dissolved oxygen, and alkalinity. Also included are analysis and interpretation of the concentrations of suspended sediment, major ions, nutrients, trace elements, and pesticides. Water-quality data from the Lake Olathe study are stored in the National Water Information System (NWIS), a USGS database located at

http://waterdata.usgs.gov/ks/nwis/qw/. Statistical summaries of results from the chemical analysis of water-quality samples and regressional-model equations are presented in tables 2-6.

Several physical properties such as specific conductance, $\mathrm{pH}$, water temperature, turbidity, and dissolved oxygen can be measured by the in-stream (or in-lake) water-quality monitors, but concentrations of most chemicals of concern cannot be measured this way. Discrete sampling of chemicals is expensive, infrequent, and adds to the level of uncertainty when comparing median chemical concentrations on a yearly basis. Instead, most chemical concentrations and loads need to be estimated on a daily, monthly, or annual basis using both water-quality monitors and regression analysis. Some of the estimated chemical concentrations detected in Cedar Creek and Lake Olathe have associated water-quality criteria (dissolved solids, nitrate, fecal coliform, and E. coli bacteria), whereas other chemicals, such as TKN, phosphorus, and geosmin are of concern to the city of 
Olathe water managers in their efforts to manage this water resource. The regression models presented in this study were developed using the least-squares process. Explanatory variables were chosen on the basis of the relation ( $p$-value less than 0.05 ) to a response variable. All of the equations developed in this report are site specific and apply only to Cedar Creek at Highway 56 or Lake Olathe in Olathe, Kansas.

\section{Physical Properties}

Physical properties were measured in conjunction with water-quality sampling. A statistical summary of measurements of physical properties made during this study along with USEPA criteria for finished/treated drinking water for selected physical properties are presented in table 2 . Mean daily values of selected physical properties for calendar years 2001 and 2002 for Cedar Creek are shown in figure 4 and for Lake Olathe in figure 5 .

Hydrologic conditions within the Lake Olathe watershed varied between 2001 and 2002. Precipitation in calendar year 2001 was 36.0 in., and precipitation in calendar year 2002 was 26.6 in., compared to the 30 -year average precipitation for the Lake Olathe watershed of approximately 40.0 in. (Kansas State University Research and Extension, 2003). Precipitation totals for calendar years 2001 and 2002 were 10 and 34 percent less than the 30-year average. Precipitation contributes to runoff, which may have resulted in increased concentrations of sediment, bacteria, and other chemicals reaching Cedar Creek during 2001 compared to 2002. Mean daily discharge (based on mean hourly discharge values) (fig. 6) as well as total streamflow volume were measured at Cedar Creek at Highway 56, and seasonal differences in discharge and volume were evident. In general, stream discharge was less in 2002 than in 2001, especially from June through October (fig. 6). Streamflow volume was three times larger in calendar year 2001 than 2002 (11,300 and 3,570 acre-ft, respectively) (Putnam and others, 2002; Putnam and Schneider, 2003). Discharge from Cedar Creek at Highway 56 was used as an explanatory variable in many of the regression-estimated chemical concentrations and subsequent load and yield relations developed for Cedar Creek.

Specific conductance values from Cedar Creek at Highway 56, Lake Olathe near dam, and Lake Olathe at upstream end, during sample collection ranged from 384 to $1,230 \mu \mathrm{S} / \mathrm{cm}$ (table 2). Specific conductance describes the ability of water to conduct an electrical current and provides an indication of ion concentrations or dissolved solids. Concentrations of dissolved solids increase with specific conductance (Hem, 1992). The lake is a composite of all the water that flows into it, and because most water comes in during low specific conductance runoff periods, specific conductance in the lake water (site 2) tends to be smaller than mean or median values at the Cedar Creek site (site 1, fig. 1).

KDHE has established a surface-water-quality criterion for aquatic life of 6.5 to 8.5 standard units for $\mathrm{pH}$ in natural surface-water systems. The $\mathrm{pH}$ of water from the three sites in this study during sample collection ranged from 6.8 to 8.9 standard units (table 2). $\mathrm{pH}$ values that were measured in Cedar Creek were within the range established by KDHE (2003); however, several values measured in Lake Olathe were greater than 8.5. $\mathrm{pH}$ values less than 7.0 exhibit acidic properties, and $\mathrm{pH}$ values larger than 70 exhibit alkaline properties. Water removal from Lake Olathe was either by discharge over the dam spillway when the lake elevation exceeded $937.5 \mathrm{ft}$ (NAVD 88) or by pumping from the intake structure to a water-treatment facility for the purpose of providing drinking water.

Lake Olathe undergoes thermal stratification during the late spring and summer months, typically from June through September. During this time, three vertical water-temperature zones are formed in Lake Olathe. The upper warmer water is called the epilimnion, the middle portion where the rate of temperature change with depth is the largest is called the metalimnion, and the deepest portion is called the hypolimnion. In Lake Olathe, the depth of the metalimnion varied from about $30 \mathrm{ft}$ in the spring to about $15 \mathrm{ft}$ in the late summer (fig. 7). In early summer, a thermocline (rapidly decreasing temperatures with depth) occurred in the metalimnion, and temperatures frequently changed with depth by as much as $10^{\circ} \mathrm{C}$ in this layer (fig. $7 B$ ). The hypolimnion varied in depth from about $40 \mathrm{ft}$ in the spring (fig. $7 A$ ) to about $25 \mathrm{ft}$ in the late summer (fig. $7 B$ ). Very little mixing of the water column occurred during the period of thermal stratification; therefore, warm water entering the lake likely would be isolated in the epilimnion. Similarly, cool water entering the lake would be entrained in the hypolimnion. In late summer and fall in temperate lakes such as Lake Olathe, declining air temperatures result in a loss of heat from the lake. Surface water cools and becomes more dense than the underlying warmer epilimnetic water (Wetzel, 2001). As the cooler surface water sinks, it is mixed within the empilimnion by a combination of convection and wind currents. The epilimnion becomes larger and larger until thermal stratification is eliminated (fig. 7C).

The turbidity of water during sample collection from the three sites in this study ranged from 0.80 to greater than 1,000 nephelometric turbidity units (NTU), with the largest values measured in Cedar Creek at Highway 56 (site 1, fig. 1), and the smallest values measured in Lake Olathe (sites 2 and 3, fig. 1) (table 2). Turbidity values varied between 2001 and 2002 and generally were smaller in 2002 than in 2001 (figs. 4 and 5). Turbidity values commonly were used as an explanatory variable to develop estimated chemical concentrations for selected constituents, including suspended sediment, nutrients, and bacteria. Turbidity has no known health effects but can interfere with disinfection of drinking water and provide a medium for microbial growth.

USEPA has developed ambient stream-water-quality criteria recommendations for turbidity on the basis of nutrient ecoregions (U.S. Environmental Protection Agency, 2000). Lake Olathe is located in Nutrient Ecoregion IX (Southeastern Temperate Forested Plains and Hills), Level III Subregion 40 (Central Irregular Plains). The recommended turbidity criterion for streams in this subregion is 15.5 NTU. USEPA has not developed a recommended turbidity criterion for lakes and reservoirs 
Table 2. Statistical summary describing physical properties, organic carbon, and suspended-sediment concentrations in water from Cedar Creek at Highway 56 and Lake 0 lathe, northeast Kansas, 2000-02.

$\left[\mathrm{ft}^{3} / \mathrm{s}\right.$, cubic feet per second; $\mu \mathrm{S} / \mathrm{cm}$, microsiemens per centimeter at 25 degrees Celsius $\left({ }^{\circ} \mathrm{C}\right)$; NTU, nephelometric turbidity units as measured using a YSI $6600,6026 \mathrm{sensor}$; mg/L, milligrams per liter; ANC, acid-neutralizing capacity; IX, U.S. Environmental Protection Agency (2000) recommended criteria for Ecoregion IX; KDHE, Kansas Department of Health and Environment (2003) surface-water-quality criterion; --, not applicable; > greater than]

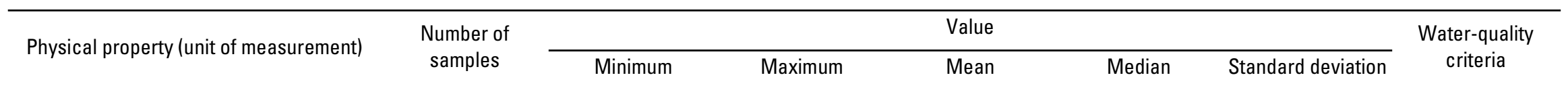

Discharge $\left(\mathrm{ft}^{3} / \mathrm{s}\right)$

Specific conductance $(\mu \mathrm{S} / \mathrm{cm})$

$\mathrm{pH}$ (standard units)

Water temperature $\left({ }^{\circ} \mathrm{C}\right)$

Turbidity (NTU)

Dissolved oxygen (mg/L)

ANC alkalinity $\left(\right.$ as $\left.\mathrm{CaCO}_{3}\right)(\mathrm{mg} / \mathrm{L})$

Total organic carbon $(\mathrm{mg} / \mathrm{L})$

Suspended-sediment concentration (mg/L)

$\begin{array}{ccc}\text { Cedar } & \text { Creek at Highway } 56 \text { (site 1, fig. 1) } \\ 1.1 & 500 & 100 \\ 384 & 1,230 & 729 \\ 7.1 & 8.1 & 7.7 \\ 1.6 & 25.5 & 15.0 \\ 7.1 & 1,000 & 220 \\ 3.1 & 21 & 9.2 \\ 99 & 280 & 140 \\ 16 & 23 & 20 \\ 14 & 1,090 & 293 \\ \text { Lake Olathe near dam (site 2, fig. 1) }\end{array}$

Specific conductance $(\mu \mathrm{S} / \mathrm{cm})$

$$
\text { epilimnion }
$$

hypolimnion

394
394

H (standard units)

$$
\begin{aligned}
& \text { epilimnion } \\
& \text { hypolimnion }
\end{aligned}
$$

394

6.8

4.6

4.4

epilimnion

hypolimnion

Turbidity (NTU)

$$
\text { epilimnion }
$$

hypolimnion

Dissolved oxygen (mg/L)

epilimnion

hypolimnion

\section{4}

.80

2.1

.05
692

692

526
563

8.0
7.4

8.9

8.9
8.0

29

9.4
707
7.7
16.1
110
9.1
130
20
75

$\begin{array}{cc}170 & -- \\ 214 & -- \\ .23 & 6.5 \text { to } 8.5 \text { (KDHE) } \\ 7.4 & --\end{array}$

280

4.1

15.5 (IX)

5.0 (KDHE)

53

4.7

\begin{tabular}{|c|c|c|}
\hline 513 & 87 & -- \\
\hline 588 & 101 & -- \\
\hline
\end{tabular}

384

$-$

$-$

8.0

.38

6.5 to 8.5 (KDHE)

7.4

.41

6.5 to $8.5(\mathrm{KDHE})$

22

19

15

60

60

19
18

12.2

9.6 
Table 2. Statistical summary describing physical properties, organic carbon, and suspended-sediment concentrations in water from Cedar Creek at Highway 56 and Lake Olathe, northeast Kansas, 2000-02.-Continued

$\left[\mathrm{ft}^{3} / \mathrm{s}\right.$, cubic feet per second; $\mu \mathrm{S} / \mathrm{cm}$, microsiemens per centimeter at 25 degrees Celsius $\left({ }^{\circ} \mathrm{C}\right)$; NTU, nephelometric turbidity units as measured using a YSI $6600,6026 \mathrm{sensor}$; mg/L, milligrams per liter; ANC, acid-neutralizing capacity; IX, U.S. Environmental Protection Agency (2000) recommended criteria for Ecoregion IX; KDHE, Kansas Department of Health and Environment (2003) surface-water-quality criterion; --, not applicable; > greater than]

\begin{tabular}{|c|c|c|c|c|c|c|c|}
\hline \multirow{2}{*}{ Physical property (unit of measurement) } & \multirow{2}{*}{$\begin{array}{l}\text { Number of } \\
\text { samples }\end{array}$} & \multicolumn{5}{|c|}{ Value } & \multirow{2}{*}{$\begin{array}{c}\text { Water-quality } \\
\text { criteria }\end{array}$} \\
\hline & & Minimum & Maximum & Mean & Median & Standard deviation & \\
\hline
\end{tabular}

ANC alkalinity (as $\left.\mathrm{CaCO}_{3}\right)(\mathrm{mg} / \mathrm{L})$

epilimnion

hypolimnion

Lake Olathe near dam (site 2, fig. 1)—Continued

Total organic carbon (mg/L)

epilimnion

hypolimnion

61

61
90

120

220

93

143

96

140

140

5.1

6.4

5.6

$-$

5.4

5.4
--

Suspended-sediment concentration (mg/L) epilimnion

hypolimnion

Specific conductance $(\mu \mathrm{S} / \mathrm{cm})$

$\mathrm{pH}$ (standard units)

Water temperature $\left({ }^{\circ} \mathrm{C}\right)$

Turbidity (NTU)

Dissolved oxygen (mg/L)

ANC alkalinity (as $\left.\mathrm{CaCO}_{3}\right)(\mathrm{mg} / \mathrm{L})$

Total organic carbon (mg/L)

Suspended-sediment concentration (mg/L)

\begin{tabular}{|c|c|c|c|c|c|c|}
\hline 5 & 410 & 675 & 518 & 500 & 97 & -- \\
\hline 5 & 7.8 & 8.4 & 8.1 & 7.9 & .2 & 6.5 to $8.5(\mathrm{KDHE})$ \\
\hline 5 & 8.4 & 28.6 & 20.8 & 23.0 & 8.2 & -- \\
\hline 5 & 15 & 110 & 47 & 34 & 36 & -- \\
\hline 5 & 5.2 & 13.8 & 7.7 & 7.0 & 3.5 & 5.0 (KDHE) \\
\hline 5 & 71 & 112 & 95 & 103 & 19 & -- \\
\hline 0 & -- & -- & -- & -- & -- & -- \\
\hline 4 & 6 & 21 & 14 & 14 & 6 & -- \\
\hline
\end{tabular}


(A) Specific conductance and turbidity
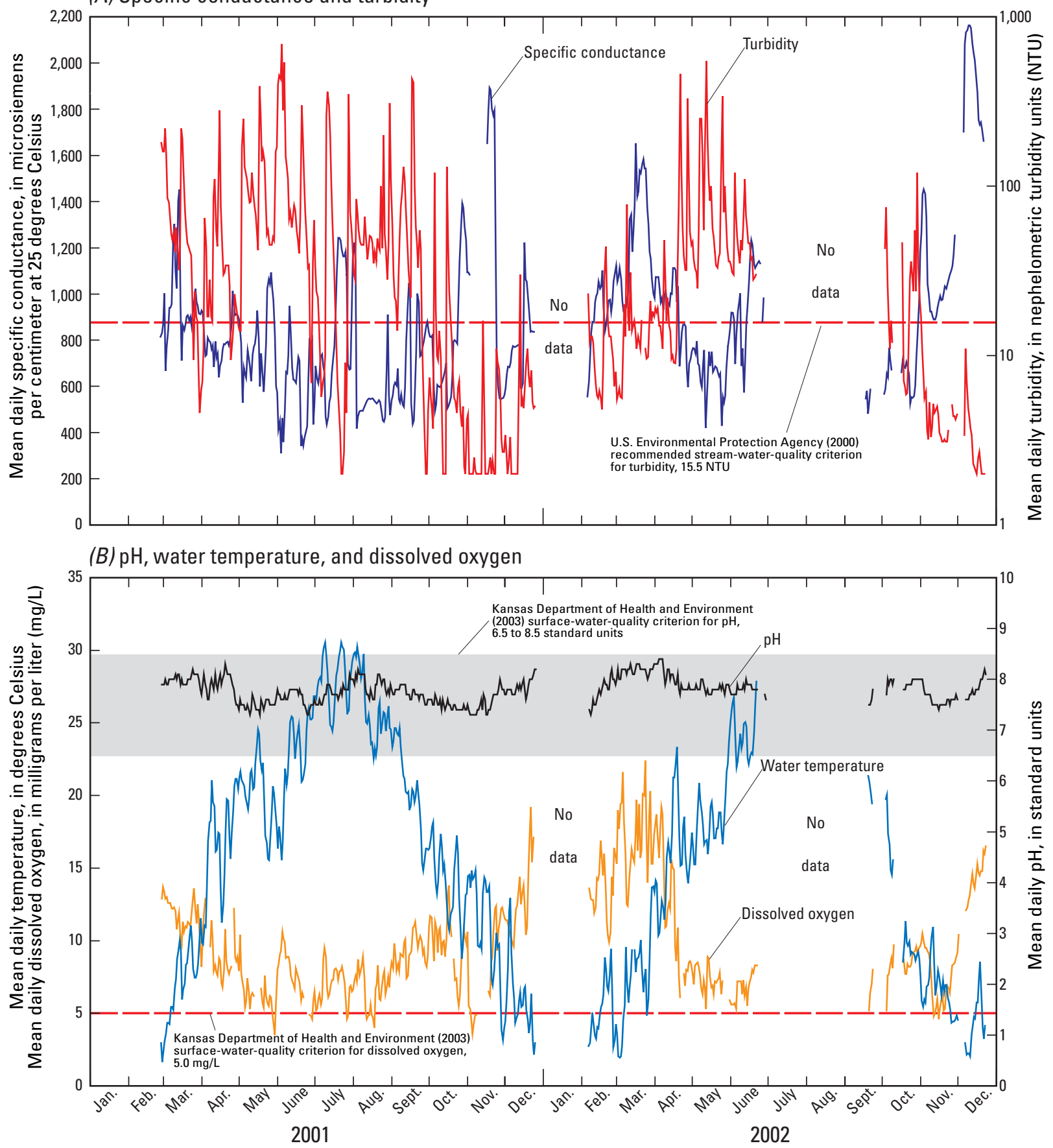

Figure 4. Mean daily $(A)$ specific conductance and turbidity, and $(B) \mathrm{pH}$, water temperature, and dissolved oxygen in water from Cedar Creek at Highway 56 (site 1), 2001-02. Location of sampling site shown in figure 1.

in Nutrient Ecoregion IX. Water from Lake Olathe used for drinking water is treated at the Olathe water-treatment facility to reduce turbidity prior to distribution to the public.

Surface-water-quality criteria for aquatic life support established by KDHE for dissolved oxygen in surface water states that the concentration of dissolved oxygen in surface water shall not be less than $5.0 \mathrm{mg} / \mathrm{L}$ as the result of artificial sources of pollution (Kansas Department of Health and Environment, 2003). Oxygen is important in many chemical and biological reactions, including respiration and photosynthesis. When oxygen concentrations in water are depleted, most aquatic organisms die or are replaced by a few specialized organisms tolerant of low oxygen levels (Horne and Goldman, 1994). The concentration of dissolved oxygen in Cedar Creek at Highway 56 (site 1) during sample collection ranged from 3.1 to $21 \mathrm{mg} / \mathrm{L}$, and ranged from 0.05 to nearly $14 \mathrm{mg} / \mathrm{L}$ in Lake Olathe (table 2). The smallest dissolved oxygen concentrations in Lake Olathe commonly were detected near the 
(A) Specific conductance and turbidity

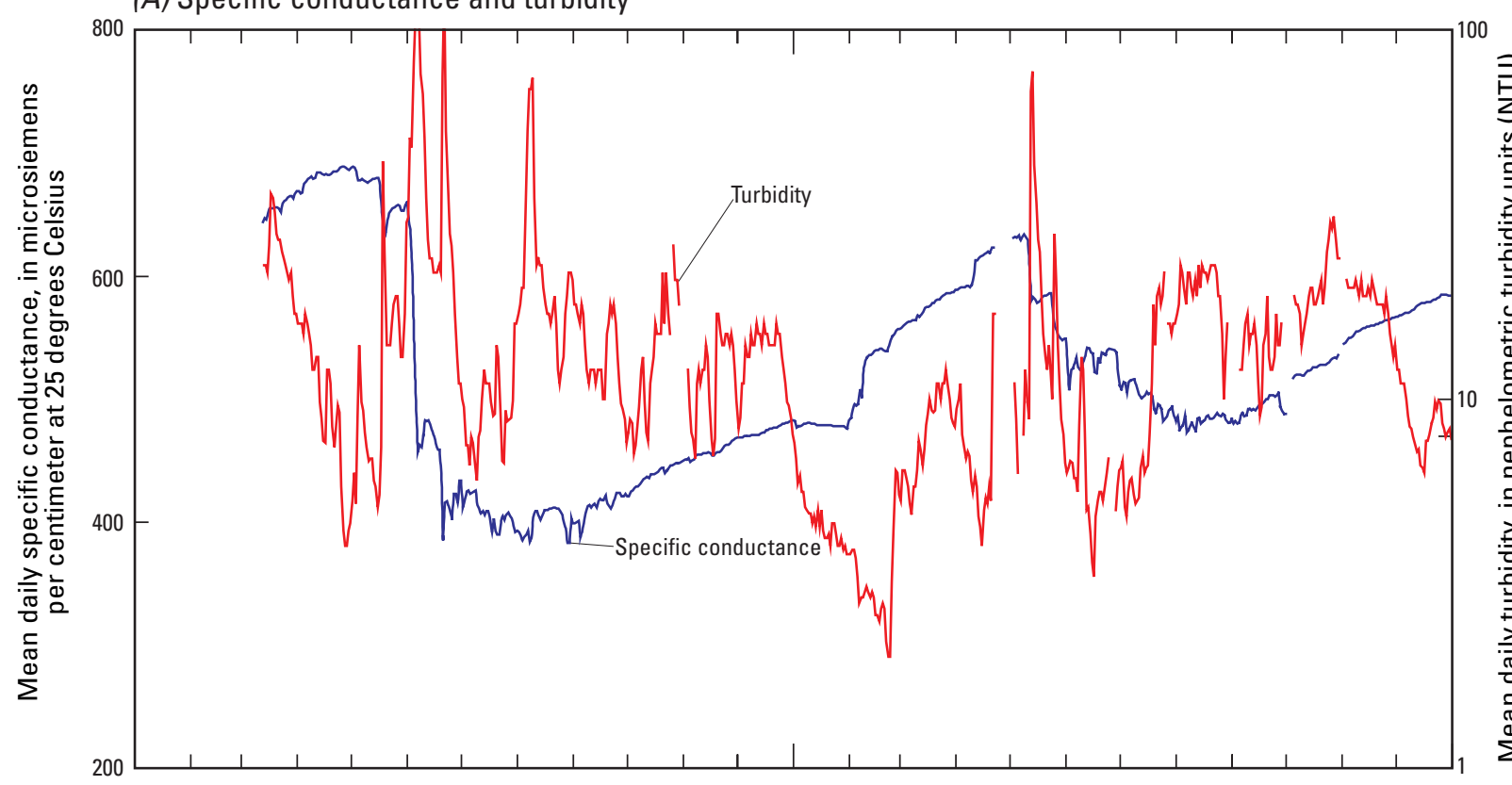

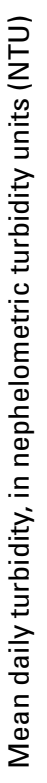

$(B) \mathrm{pH}$, water temperature, and dissolved oxygen

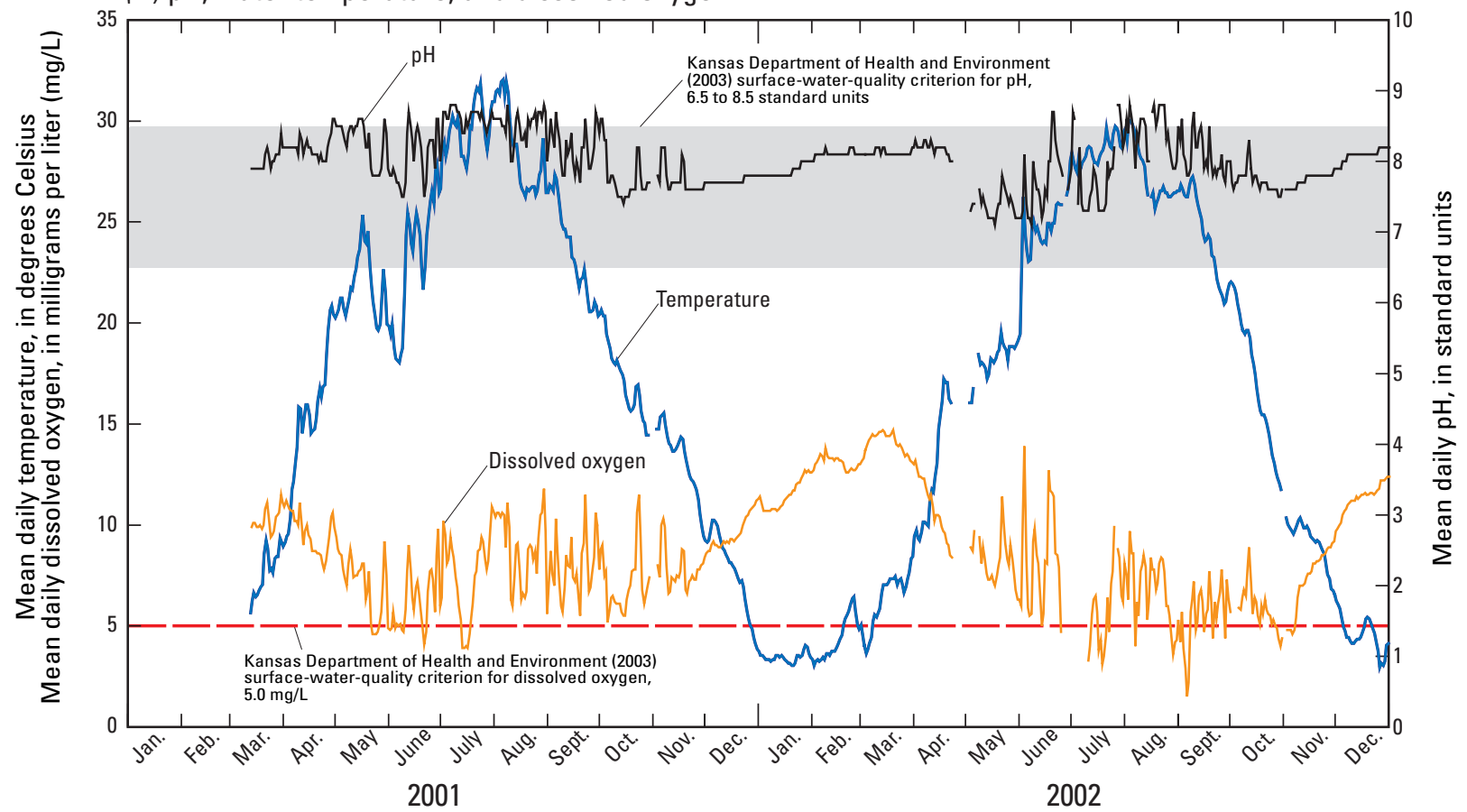

Figure 5. Mean daily $(A)$ specific conductance and turbidity, and $(B) \mathrm{pH}$, water temperature, and dissolved oxygen in water from Lake Olathe near dam (site 2), 2001-02. Location of sampling site shown in figure 1.

bottom of Lake Olathe during the summer months of July and August after the lake had stratified. The small dissolved oxygen concentrations likely are a natural phenomenon that occurs as part of the lake stratification process.

The acid-neutralizing capacity (ANC) of $\mathrm{CaCO}_{3}$ (calcium carbonate) is a measure of the acid-buffering capacity of unfiltered water. In this report, ANC will be referred to as alkalinity, although alkalinity refers to the acid-buffering capacity of filtered water. Alkalinity as $\mathrm{CaCO}_{3}$ ranged from 99 to $280 \mathrm{mg} / \mathrm{L}$ in Cedar Creek at Highway 56 (site 1), and from 61 to $220 \mathrm{mg} / \mathrm{L}$ in Lake Olathe (sites 2 and 3) (table 2). Excessive alkalinity in water may give the water an unpleasant taste, increase $\mathrm{pH}$, and decrease biological activity (Hem, 1992). Alkalinity was not considered excessive in water from Cedar Creek or Lake Olathe, and values were smaller than those determined in a previous ground-water study of the Olathe landfill (Rasmussen and others, 1994). 


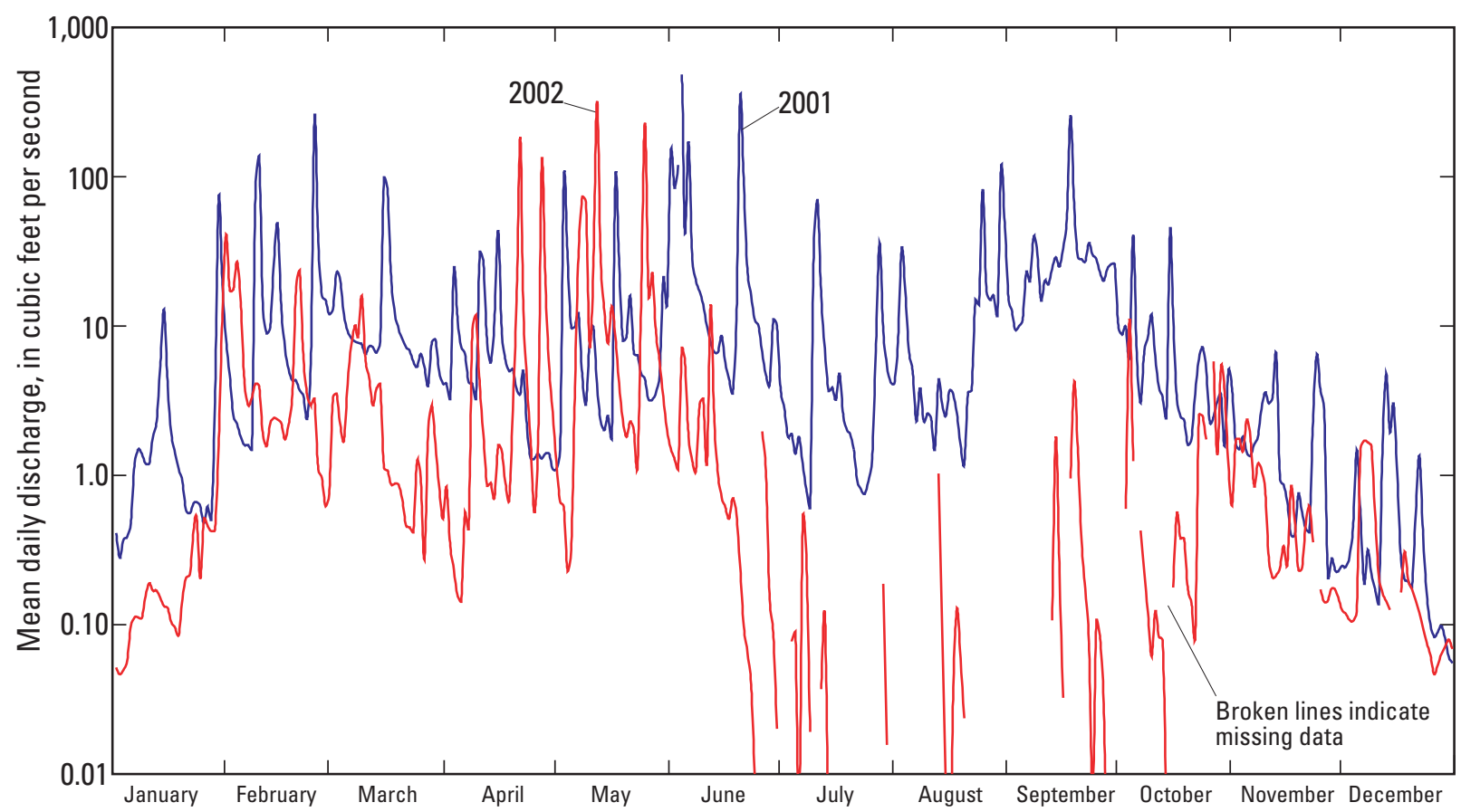

Figure 6. Mean daily stream discharge from Cedar Creek at Highway 56 (site 1), 2001-02. Location of sampling site shown in figure 1.

\section{Suspended Sediment}

Suspended-sediment concentration is an important measure of water-quality conditions and is the result of land disturbance and the natural weathering of soils, rocks, and minerals. USEPA and KDHE do not have numeric surface-water-quality criteria for suspended-sediment concentration. However, narrative surface-water-quality criteria established by KDHE for suspended solids state that "suspended solids added to surface waters by artificial sources shall not interfere with the behavior, reproduction, physical habitat, or other factors related to the survival and propagation of aquatic or semiaquatic life or terrestrial life" (Kansas Department of Health and Environment, 2001). Suspended-sediment concentrations ranged from 14 to $1,090 \mathrm{mg} / \mathrm{L}$ in Cedar Creek at Highway 56 (site 1) and from 2 to $79 \mathrm{mg} / \mathrm{L}$ in Lake Olathe (table 2). Larger concentrations were attributed to sampling periods during or following runoff when large amounts of suspended sediment were transported along with streamflow through Cedar Creek and into Lake Olathe.

Suspended-sediment concentrations often are estimated using streamflow regression models. However in this study, turbidity provided better estimates of suspended-sediment concentrations than streamflow. The regression model used to estimate suspended-sediment concentration in Cedar Creek was:

$$
\operatorname{logSSC}=0.002(\text { Turb })+1.54,
$$

where

SSC is suspended-sediment concentration, in milligrams per liter; and
Turb is continuous turbidity, in nephelometric turbidity units.

The coefficient of determination, $\mathrm{R}^{2}$, was 0.78 ( $p$-value less than 0.001 ), indicating a statistically significant relation between suspended-sediment concentration and turbidity. Turbidity is an optical property related to particles in solution scattering light and, therefore, has a relation with suspendedsediment concentration.

\section{Major lons and Dissolved Solids}

Surface water contains a wide variety of molecules and ions from the weathering of soils in the watershed, the atmosphere, and sediments. The dissolved chemicals (molecules and ions) that give water its unique chemistry are the cations (positively charged ions) of calcium, magnesium, potassium, silica, and sodium; and the anions (negatively charged ions) of sulfate, chloride, and fluoride. Concentrations of the cations and anions usually are expressed in units of milligrams per liter $(\mathrm{mg} / \mathrm{L})$. Humans can have substantial effects on water chemistry by supplying additional ions to water. Excessive disturbance of the land surface as a result of agricultural crop production, as well as commercial and residential land development can cause higher rates of leaching and erosion by removing land cover, exposing soils, and increasing water-runoff velocity. These effects can lead to increased cation and anion loading (transport) to streams and lakes. Although basic cations and anions commonly are not considered contaminants, increased ion concentrations may provide information about potential 


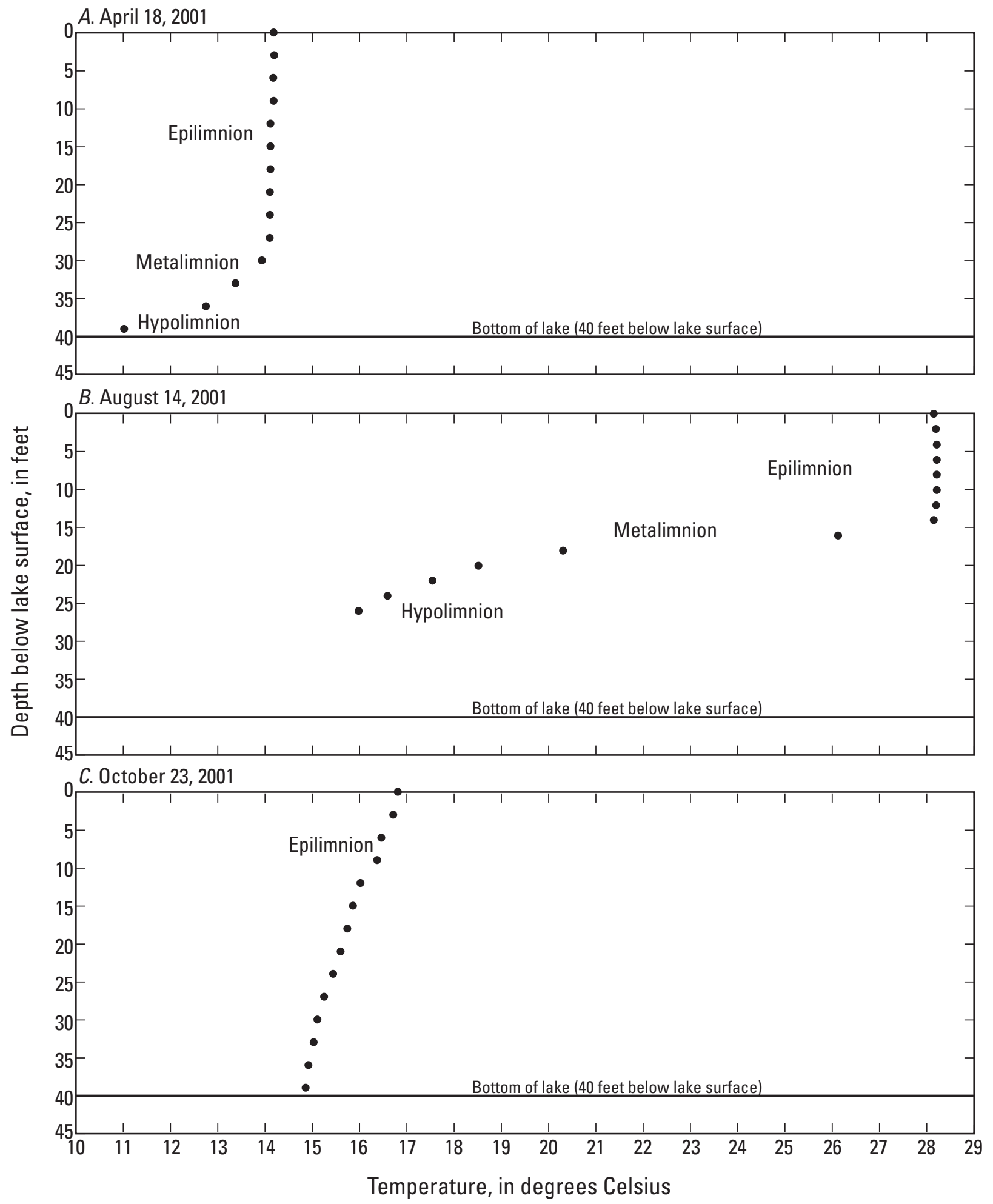

Figure 7. Water temperature variation with depth in Lake Olathe near dam (site 2), 2001. Location of sampling site shown in figure 1. 


\section{Surface-Water-Quality Conditions and Relation to Taste-and-Odor Occurrences in the Lake Olathe Watershed, Northeast Kansas, 2000-02}

sources of contaminants that are of concern (nutrients, trace elements, and synthetic organic compounds).

The large sulfate concentrations in water from Cedar Creek (table 3) likely come from weathering of soil and rock material containing either gypsum or iron sulfides (Wetzel, 2001). Sulfate also can be attributed to industrial wastes (Wetzel, 2001).

Dissolved-solids concentration is the quantity of dissolved material in a sample of water, and it is commonly used in evaluating water quality and in comparing water from different sources (Hem, 1992, p. 157). Median concentrations of dissolved solids at all three sampling sites in the Olathe watershed were very similar, ranging from 290 to $380 \mathrm{mg} / \mathrm{L}$ (table 3).

\section{Nutrients}

The distribution of chemicals in Lake Olathe, especially nutrients, is affected by thermal stratification (layering of the water according to temperatures). Following thermal stratification, nutrients often are depleted in the epilimnion as a result of algal uptake, while nutrient concentrations in the hypolimnion remain constant or increase (Horne and Goldman, 1994, p. 19).

Nutrients, such as biologically available forms of dissolved nitrogen and phosphorus, can affect the trophic condition or degree of biological activity in a lake. Nutrient enrichment (eutrophication) to a lake can lead to excessive growth of algae (algal blooms) and other aquatic plants. Eutrophication also may reduce the aesthetic and recreational value of water and, in severe cases, may stress or kill aquatic organisms as a result of dissolved oxygen depletion following the die off of algal blooms. Algal blooms are responsible for many waterquality-related problems in lakes including but not limited to high turbidity, unpleasant tastes and odors, and disruptions to water-treatment facilities.

To understand and manage the problems associated with eutrophication in lakes, it is important to understand the complex dynamics between nutrient input and the in-lake concentrations of nitrogen and phosphorus, and seasonal responses of algal populations.

\section{Forms of Nitrogen}

Nitrogen commonly occurs in natural water in several different forms including dissolved molecular nitrogen $\left(\mathrm{N}_{2}\right)$, organic compounds (amino acids, amines, proteins), ammonia [includes ammonia $\left(\mathrm{NH}_{3}\right)$ and ammonium $\left(\mathrm{NH}_{4}{ }^{+}\right)$ions], nitrite $\left(\mathrm{NO}_{2}^{-}\right)$, and nitrate $\left(\mathrm{NO}_{3}{ }^{-}\right)$. Sources of nitrogen include fixation of atmospheric molecular nitrogen by bacteria and algae, the decay of organic material such as algae or washed-in leaf material, animal wastes, improperly functioning septic systems, and urban runoff. Fertilizers applied to cropland provide large amounts of both soluble nitrogen compounds, such as ammonium nitrate, and insoluble compounds, such as total TKN. TKN is relatively immobile in soil because of its adsorption to soil surfaces. However, under oxygen-rich conditions, TKN can be converted to nitrite and nitrate and enter the ground- and surface-water systems (Horne and Goldman, 1994, p. 137).

Nitrogen can be transformed from one form to another by a biologically catalyzed reaction. Bacteria and blue-green algae (cyanobacteria) can transform nitrogen gas to ammonia by an enzyme in a process known as nitrogen fixation (Horne and Goldman, 1994, p. 145). Other bacteria catalyze the oxidation of ammonia to nitrite, then to nitrate by a process known as nitrification; the process occurs quickly in the oxygen-rich environments of most streams. Ammonia is the preferred form of algal uptake and is followed by nitrite and nitrate and then dissolved molecular nitrogen (Wetzel, 2001). Organisms can use these forms of nitrogen and incorporate the nitrogen into algal cells, which in turn decay and release nitrogen in the various forms of ammonia.

Mean and median concentrations of the various nitrogen forms were larger in Cedar Creek than in the epilimnion of Lake Olathe (table 4). Maximum and median concentrations of TKN and TIN were larger in Cedar Creek than in the Lake Olathe epilimnion. The concentration of TKN in Cedar Creek ranged from 0.49 to $3.0 \mathrm{mg} / \mathrm{L}$, and concentrations of TIN ranged from 0.19 to $3.3 \mathrm{mg} / \mathrm{L}$.

The following regression models were developed for Cedar Creek to assist in the explanation of nutrient concentrations and loads to Lake Olathe:

$$
\begin{gathered}
\mathrm{TKN}=1.38 \log (\mathrm{SSC})-1.56, \\
\mathrm{TKN}=0.002 \mathrm{Turb}+0.75, \text { and } \\
\mathrm{TIN}=-0.14 \mathrm{WT}+0.69 \mathrm{pH}-1.33,
\end{gathered}
$$

where

TKN is the total ammonia plus organic nitrogen as nitrogen concentration, in milligrams per liter;

SSC is the suspended-sediment concentration, in milligrams per liter;

Turb is turbidity, in nephelometric turbidity units;

TIN is the dissolved nitrite plus nitrate as nitrogen concentration, in milligrams per liter;

WT is water temperature, in degrees Celsius; and

$\mathrm{pH}$ is the negative log of the hydrogen ion concentration, in standard units.

The coefficients of determination, $\mathrm{R}^{2}$, for TKN and TIN using equations $2-4$ were $0.87,0.60$, and 0.63 , respectively, and $p$-values were less than $0.001,0.002$, and 0.01 , respectively (table 5), indicating a statistically significant relation using SSC, Turb, WT, and pH in these equations. The relation among TKN, suspended-sediment concentration, and turbidity is not surprising because of the adsorption preference of TKN to soil particles. The relation among TIN, water temperature, and $\mathrm{pH}$ may be explained through algal dynamics. Water temperature and $\mathrm{pH}$ affect algal production, and algae utilize TIN for cellular processes.

The concentration of TKN in the epilimnion of Lake Olathe ranged from 0.56 to $1.1 \mathrm{mg} / \mathrm{L}$, and TIN ranged 
Table 3. Statistical summary describing major-ion and dissolved-solids concentrations in water from Cedar Creek at Highway 56 and Lake Olathe, northeast Kansas, 2000-02.

[SWDR, Secondary Drinking Water Regulation (U.S. Environmental Protection Agency, 2003); MCL, Maximum Contaminant Level (U.S. Environmental Protection Agency, 2003); --, not applicable]

\begin{tabular}{|c|c|c|c|c|c|c|c|}
\hline \multirow[b]{2}{*}{ Major ion } & \multirow{2}{*}{$\begin{array}{c}\text { Number of } \\
\text { samples }\end{array}$} & \multicolumn{6}{|c|}{ Concentration, in milligrams per liter } \\
\hline & & Minimum & Maximum & Mean & Median & Standard deviation & $\begin{array}{c}\text { Water-quality } \\
\text { criteria }{ }^{1}\end{array}$ \\
\hline \multicolumn{8}{|c|}{ Cedar Creek at Highway 56 (site 1, fig. 1) } \\
\hline Calcium & 8 & 45 & 89 & 64 & 64 & 18 & -- \\
\hline Magnesium & 8 & 9.2 & 23 & 14 & 14 & 5.0 & -- \\
\hline Sodium & 8 & 24 & 65 & 48 & 47 & 14 & -- \\
\hline Potassium & 8 & 3.5 & 5.9 & 4.5 & 4.3 & .78 & -- \\
\hline Sulfate & 8 & 49 & 220 & 140 & 140 & 66 & 250 (SDWR) \\
\hline Chloride & 8 & 20 & 100 & 53 & 51 & 28 & 250 (SDWR) \\
\hline Fluoride & 8 & .2 & .4 & .3 & .3 & .1 & 4.0 (MCL) \\
\hline Silica & 8 & 4.3 & 8.2 & 5.7 & 5.4 & 1.4 & -- \\
\hline Dissolved solids & 8 & 330 & 580 & 430 & 380 & 96 & -- \\
\hline \multicolumn{8}{|c|}{ Lake Olathe near dam (site 2, fig. 1) } \\
\hline Calcium & & & & & & & -- \\
\hline epilimnion & 13 & 36 & 60 & 46 & 46 & 7.6 & -- \\
\hline hypolimnion & 10 & 42 & 67 & 56 & 56 & 8.2 & -- \\
\hline Magnesium & & & & & & & -- \\
\hline epilimnion & 13 & 8.0 & 10 & 9.4 & 9.4 & .6 & -- \\
\hline hypolimnion & 11 & 6.3 & 12 & 9.6 & 9.9 & 1.6 & -- \\
\hline Sodium & & & & & & & -- \\
\hline epilimnion & 13 & 26 & 51 & 36 & 36 & 7.2 & -- \\
\hline hypolimnion & 11 & 21 & 57 & 35 & 34 & 9.6 & -- \\
\hline Potassium & & & & & & & -- \\
\hline epilimnion & 13 & 3.4 & 4.5 & 3.7 & 3.7 & .27 & -- \\
\hline hypolimnion & 11 & 3.4 & 4.3 & 3.8 & 3.7 & .32 & -- \\
\hline Sulfate & & & & & & & 250 (SDWR) \\
\hline epilimnion & 13 & 58 & 82 & 69 & 68 & 6.6 & -- \\
\hline hypolimnion & 10 & 22 & 93 & 48 & 44 & 23 & -- \\
\hline
\end{tabular}


Table 3. Statistical summary describing major-ion and dissolved-solids concentrations in water from Cedar Creek at Highway 56 and Lake Olathe, northeast Kansas, 2000-02.-Continued

[SWDR, Secondary Drinking Water Regulation (U.S. Environmental Protection Agency, 2003); MCL, Maximum Contaminant Level (U.S. Environmental Protection Agency, 2003); --, not applicable]

\begin{tabular}{|c|c|c|c|c|c|c|c|}
\hline \multirow[b]{2}{*}{ Major ion } & \multirow{2}{*}{$\begin{array}{l}\text { Number of } \\
\text { samples }\end{array}$} & \multicolumn{6}{|c|}{ Concentration, in milligrams per liter } \\
\hline & & Minimum & Maximum & Mean & Median & Standard deviation & $\begin{array}{c}\text { Water-quality } \\
\text { criteria }^{1}\end{array}$ \\
\hline \multicolumn{8}{|c|}{ Lake Olathe near dam (site 2, fig. 1) —Continued } \\
\hline Chloride & & & & & & & 250 (SDWR) \\
\hline epilimnion & 13 & 27 & 77 & 47 & 47 & 14 & -- \\
\hline hypolimnion & 11 & 27 & 77 & 47 & 46 & 14 & -- \\
\hline Fluoride & & & & & & & 4.0 (MCL) \\
\hline epilimnion & 13 & .2 & .3 & .3 & .3 & 0 & -- \\
\hline hypolimnion & 11 & .2 & .3 & .2 & .2 & 0 & -- \\
\hline Silica & & & & & & & -- \\
\hline epilimnion & 13 & 1.5 & 5.8 & 4.2 & 4.8 & 1.4 & -- \\
\hline hypolimnion & 11 & 3.1 & 9.7 & 6.3 & 5.7 & 2.0 & -- \\
\hline Dissolved solids & & & & & & & -- \\
\hline epilimnion & 13 & 240 & 410 & 300 & 380 & 48 & -- \\
\hline hypolimnion & 10 & 220 & 420 & 310 & 290 & 57 & -- \\
\hline \multicolumn{8}{|c|}{ Lake Olathe at upstream end (site 3 , fig. 1) } \\
\hline Calcium & 5 & 38 & 49 & 44 & 47 & 5.2 & -- \\
\hline Magnesium & 5 & 9.2 & 9.8 & 9.5 & 9.4 & .2 & -- \\
\hline Sodium & 5 & 29 & 41 & 36 & 35 & 4.9 & -- \\
\hline Potassium & 5 & 3.5 & 4.1 & 3.8 & 3.7 & .26 & -- \\
\hline Sulfate & 5 & 64 & 73 & 67 & 65 & 4.0 & 250 (SDWR) \\
\hline Chloride & 5 & 29 & 53 & 45 & 48 & 9.5 & 250 (SDWR) \\
\hline Fluoride & 5 & .3 & .3 & .3 & .3 & 0 & 4.0 (MCL) \\
\hline Silica & 5 & 2.4 & 5.4 & 3.8 & 3.6 & 1.2 & -- \\
\hline Dissolved solids & 5 & 230 & 300 & 280 & 290 & 27 & -- \\
\hline
\end{tabular}

${ }^{1}$ The Maximum Contaminant Level (MCL) and Secondary Drinking Water Regulation (SWDR) are standards that apply to treated drinking water. 
Table 4. Statistical summary describing nutrient concentrations in water from Cedar Creek at Highway 56 and Lake 0lathe, northeast Kansas, $2000-02$.

[MCL, Maximum Contaminant Level (U.S. Environmental Protection Agency, 2003); <, less than; E, estimated; --, not applicable]

\begin{tabular}{|c|c|c|c|c|c|c|}
\hline \multirow[b]{2}{*}{ Nutrient } & \multirow{2}{*}{$\begin{array}{c}\text { Number of } \\
\text { samples }\end{array}$} & \multicolumn{5}{|c|}{ Concentration, in milligrams per liter } \\
\hline & & Minimum & Maximum & Mean & Median & Standard deviation $\begin{array}{c}\text { Water-quality } \\
\text { criteria }^{1}\end{array}$ \\
\hline
\end{tabular}

Ammonia, dissolved, as nitrogen

Cedar Creek at Highway 56 (site 1, fig. 1)

Ammonia plus dissolved organic nitrogen, as nitrogen

13
13
13

$$
\text { (TKN) }
$$

Nitrite plus nitrate, dissolved, as nitrogen (TIN)

Nitrite, dissolved, as nitrogen

13
13

\section{Nitrogen, total (TN)}

Phosphorus, dissolved, as phosphorus

Phosphate, ortho, dissolved, as phosphorus (OP)

Phosphorus, total, as phosphorus (TP)

13

13

13

Ammonia, dissolved, as nitrogen

epilimnion

hypolimnion

Ammonia plus dissolved organic nitrogen, as nitrogen

$$
\text { epilimnion }
$$

hypolimnion

Ammonia plus organic nitrogen, total, as nitrogen

(TKN)

epilimnion

hypolimnion

Nitrite plus nitrate, dissolved, as nitrogen (TIN)

$$
\text { epilimnion }
$$

hypolimnion

19

12

19

$\begin{array}{ll}19 & .32 \\ 12 & .86\end{array}$

.86

$19 \quad .56$

$12 \quad .93$

$19 \quad .03$

$12 \quad .03$

19

epilimnion

hypolimnion

$<.02$

.43

.01

.01

$<0.02$
.33
.49
.19
.01
.93
.03
$<.01$
.07

0.28
1.0
3.0

Lake Olathe near dam (site 2, fig. 1)

0.12
.59
1.3

1.4
.04

2.7
.07
.04
.28

0.11
.55
1.1

1.7
.02

2.2
.06
.03
.15

0.09
.22
.83
1.1
.03
1.6
.04
.04
.25

$--$

$-$

10 (MCL)

.13

.43

5.3

.83

6.0

1.8

.46

2.4

.82

2.6

.51

.30

.03

.18

.11

.03

.09
.8
.46
.4

.82
.6
.51
.30
.03
.03

.41

1.8

.14

1.7

.81

2.0

.16

1.7

10 (MCL)

.32

.05

.64

.49

.02

.04

.03 
[MCL, Maximum Contaminant Level (U.S. Environmental Protection Agency, 2003); <, less than; E, estimated; --, not applicable]

\begin{tabular}{|c|c|c|c|c|c|c|c|}
\hline \multirow[b]{2}{*}{ Nutrient } & \multirow{2}{*}{$\begin{array}{l}\text { Number of } \\
\text { samples }\end{array}$} & \multicolumn{6}{|c|}{ Concentration, in milligrams per liter } \\
\hline & & Minimum & Maximum & Mean & Median & Standard deviation & $\begin{array}{c}\text { Water-quality } \\
\text { criteria }^{1}\end{array}$ \\
\hline \multicolumn{8}{|c|}{ Lake Olathe near dam (site 2, fig. 1)—Continued } \\
\hline \multicolumn{8}{|l|}{ Nitrogen, total (TN) } \\
\hline epilimnion & 19 & 0.72 & 3.3 & 1.3 & 1.2 & 0.67 & -- \\
\hline hypolimnion & 12 & 1.2 & 6.3 & 2.9 & 2.6 & 1.5 & \\
\hline \multicolumn{8}{|l|}{ Phosphorus, dissolved, as phosphorus } \\
\hline epilimnion & 19 & .02 & .07 & .06 & .06 & .01 & -- \\
\hline hypolimnion & 12 & .04 & .66 & .18 & .08 & .21 & -- \\
\hline \multicolumn{8}{|l|}{ Phosphate, ortho, dissolved, as phosphorus (OP) } \\
\hline epilimnion & 19 & $<.01$ & .05 & .02 & .02 & .01 & -- \\
\hline hypolimnion & 12 & $<.01$ & .65 & .16 & .06 & .20 & -- \\
\hline \multicolumn{8}{|l|}{ Phosphorus, total, as phosphorus (TP) } \\
\hline epilimnion & 19 & $.03 \mathrm{E}$ & .14 & .05 & .04 & .02 & -- \\
\hline hypolimnion & 12 & .06 & .84 & .29 & .17 & .27 & -- \\
\hline \multicolumn{8}{|c|}{ Lake Olathe at upstream end (site 3, fig. 1) } \\
\hline Ammonia, dissolved, as nitrogen & 5 & $<.02$ & .23 & .16 & .21 & .11 & -- \\
\hline Ammonia plus dissolved organic nitrogen, as nitrogen & 5 & .33 & .72 & .50 & .40 & .18 & -- \\
\hline $\begin{array}{l}\text { Ammonia plus organic nitrogen, total, as nitrogen } \\
\text { (TKN) }\end{array}$ & 5 & .71 & .94 & .82 & .83 & .09 & -- \\
\hline Nitrite plus nitrate, dissolved, as nitrogen (TIN) & 5 & $<.05$ & 2.4 & 1.3 & 1.3 & 1.6 & 10 (MCL) \\
\hline Nitrite, dissolved, as nitrogen & 5 & $<.01$ & .06 & .05 & .05 & .01 & -- \\
\hline Nitrogen, total (TN) & 5 & .67 & 3.2 & 1.3 & 1.0 & 1.1 & -- \\
\hline Phosphorus, dissolved, as phosphorus & 5 & $<.05$ & .07 & .07 & .07 & .07 & -- \\
\hline Phosphate, ortho, dissolved, as phosphorus (OP) & 5 & $<.01$ & .04 & .04 & .04 & .04 & -- \\
\hline Phosphorus, total, as phosphorus (TP) & 5 & $.04 \mathrm{E}$ & .13 & .07 & .05 & .04 & -- \\
\hline
\end{tabular}

\footnotetext{
${ }^{1}$ The Maximum Contaminant Level (MCL) is a standard that applies to treated drinking water.
} 
Table 5. Summary of regression model equations for selected constituents in water from Cedar Creek at Highway 56, 0lathe, northeast Kansas, $2000-02$.

[MSE, mean square error; $\mathrm{R}^{2}$, coefficient of determination; $\mathrm{n}$, number of samples; SSx, sum of square of errors; $p$-value, probability; t-statistic, measure of significance of coefficients; $\mu$ S/cm, microsiemens per centimeter at 25 degrees Celsius; log, base-10 logarithm; Turb, turbidity, in nephelometric turbidity units; WT, water temperature, in degrees Celsius; pH, in standard units; Q, discharge, in cubic feet per second; $\mathrm{mg} / \mathrm{L}$, milligrams per liter; $\mu \mathrm{g} / \mathrm{L}$, micrograms per liter; col/100 mL, colonies per 100 milliliters of water; >, greater than; <, less than; --, not applicable]

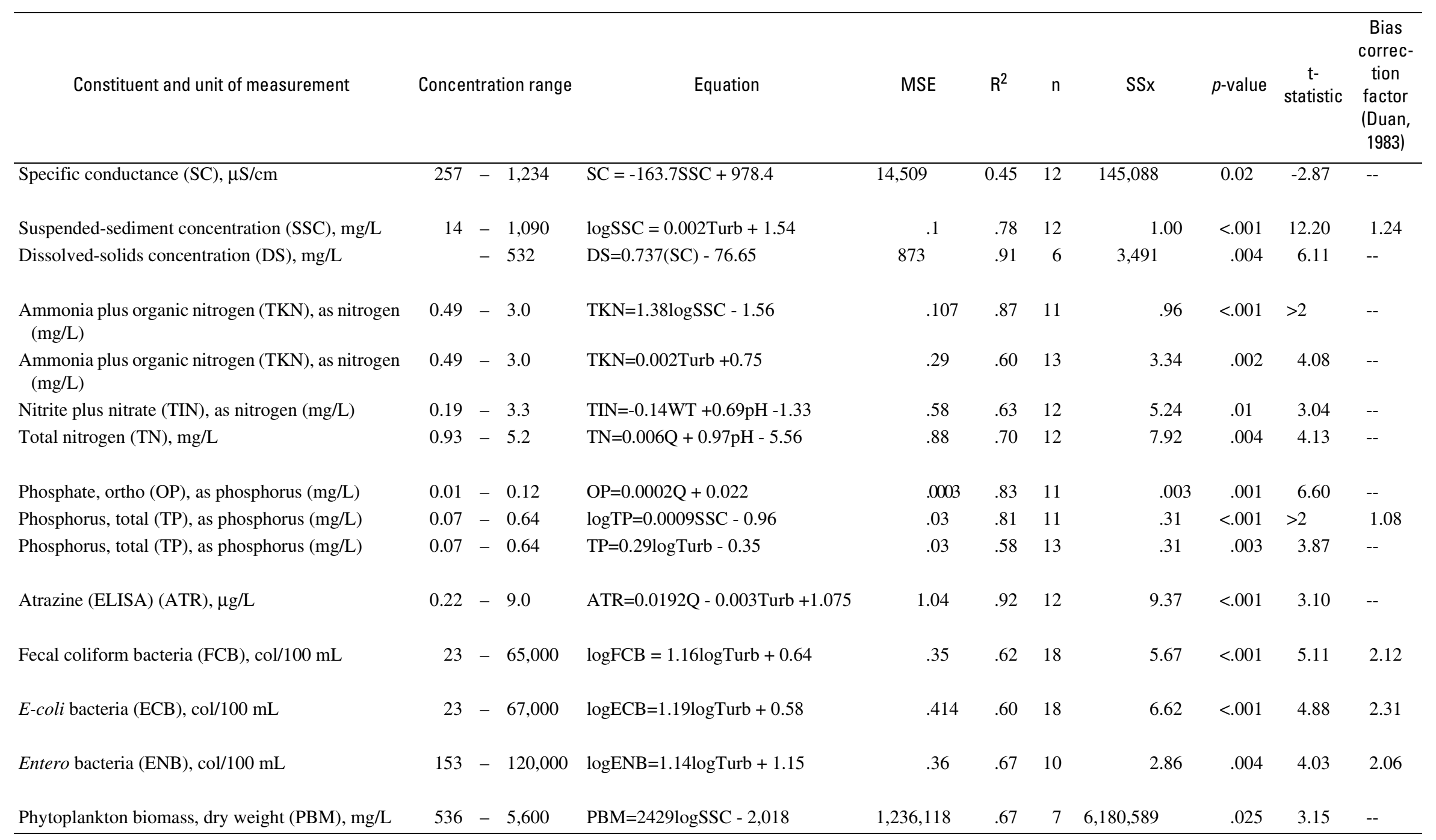




\section{Surface-Water-Quality Conditions and Relation to Taste-and-Odor Occurrences in the Lake Olathe Watershed, Northeast Kansas, 2000-02}

from 0.03 to $2.2 \mathrm{mg} / \mathrm{L}$ (table 4). Mean and median concentrations of TKN in the hypolimnion of Lake Olathe were larger than concentrations in the epilimnion (table 4). The concentration range of TKN in the hypolimnion varied from 0.93 to $6.2 \mathrm{mg} / \mathrm{L}$, which may be in response to TKN desorption from lake-bottom sediments and resuspension into the lake hypolimnion during periods of low hypolimnetic oxygen content. Concentrations of TIN in the hypolimnion, however, were smaller than in the epilimnion, ranging from 0.03 to $1.8 \mathrm{mg} / \mathrm{L}$.

A regression model was developed for Lake Olathe to estimate TIN concentrations in the epilimnion:

$$
\mathrm{TIN}=0.0261 \mathrm{Turb}+0.0039 \mathrm{SC}-0.0278 \mathrm{WT}-1.6385,
$$

where

TIN is the dissolved nitrite plus nitrate as nitrogen concentration, in milligrams per liter;

Turb is turbidity, in nephelometric turbidity units;

$\mathrm{SC}$ is specific conductance, in microsiemens per centimeter at $25{ }^{\circ} \mathrm{C}$; and

WT is water temperature, in degrees Celsius.

The coefficient of determination, $\mathrm{R}^{2}$, for TIN was 0.94 , and the $p$-value was 0.009 (table 6 ), indicating a statistically significant relation using Turb, SC, and WT in equation 5.

Algal dynamics may be partially responsible for the relation among TIN, turbidity, and specific conductance. Algae use TIN as a nutrient source, and increased turbidity may reduce light availability and interfere with nutrient uptake by lightlimited algae, resulting in increased TIN concentrations in the epilimnion. Similarly, various species of algae respond differently to changes in specific conductance (Wetzel, 2001,

p. 172-177). Algal species that use TIN in Lake Olathe may decline with an increase in specific conductance, thus reducing TIN uptake. This theory is presently speculative because there are many causal factors affecting algal dynamics, and no studies to date have investigated this phenomenon (Wetzel, 2001).

Human health-based water-quality regulations have been established for nitrate in drinking water because of potential ill effects to children. USEPA and KDHE have established a surface-water-quality criterion for domestic water supplies for TIN not to exceed $10 \mathrm{mg} / \mathrm{L}$ as nitrogen (U.S. Environmental Protection Agency, 1986; Kansas Department of Health and Environment, 2001). TIN did not exceed $10 \mathrm{mg} / \mathrm{L}$ as nitrogen in water samples from Cedar Creek or Lake Olathe during any period of the study.

\section{Forms of Phosphorus}

Phosphorus is a nutrient essential for the growth and reproduction of plants and animals. It is used as an energy source in the cells of plants and animals and can have a direct effect on the production of phytoplankton populations, an important component of the food chain. Phosphorus availability also is a critical factor in eutrophication because it is often the limiting nutrient that controls biological production rates (Hem, 1992, p. 128). Excessive phosphorus in water bodies, where nitrogen is not a limiting factor, can accelerate eutrophication. Excessive phosphorus concentrations in soils from both natural and human-related sources can have detrimental effects on lakes located downgradient from source areas and can promote excessive algal growth that may lead to taste-and-odor occurrences in treated drinking water. Common sources of human-related phosphorus include inorganic phosphates added to agricultural soils as fertilizer, manure from confined animalfeeding operations, and treated wastewater discharged into receiving streams.

The form of phosphorus available for use by aquatic biota is orthophosphate $\left(\mathrm{PO}_{4}^{-3}\right)$, an inorganic fraction that represents less than 10 percent of the total available phosphorus in most natural water (Wetzel, 2001, p. 240). Forms of orthophosphate are produced by natural processes through the weathering of rocks and minerals, but major human-related sources include partially treated and untreated sewage, runoff from agricultural sites, and application of some lawn fertilizers. Currently (2004), there are no established drinking-water criteria for orthophosphate (OP) or total phosphorus (TP); however, the USEPA desired goal for TP to prevent nuisance growth of aquatic vegetation is $0.1 \mathrm{mg} / \mathrm{L}$ in flowing water and less than $0.05 \mathrm{mg} / \mathrm{L}$ where rivers enter lakes and reservoirs (U.S. Environmental Protection Agency, 1986).

Phosphorus concentrations in Cedar Creek typically were larger than those in the epilimnion of Lake Olathe. The concentration ranges of orthophosphate and total phosphorus in Cedar Creek were less than 0.01 to $0.12 \mathrm{mg} / \mathrm{L}$ and 0.07 to $0.75 \mathrm{mg} / \mathrm{L}$, respectively, compared with less than 0.01 to $0.05 \mathrm{mg} / \mathrm{L}$ and 0.03 to $0.14 \mathrm{mg} / \mathrm{L}$, respectively, in the epilimnion at Lake Olathe (table 4). Median concentrations of orthophosphate were similar in both the creek and the lake epilimnion ( 0.03 and $0.02 \mathrm{mg} / \mathrm{L}$, respectively), but median total phosphorus concentrations were almost four times greater in Cedar Creek than in the epiliminion of Lake Olathe $(0.15$ and $0.04 \mathrm{mg} / \mathrm{L}$, respectively). Differences in total phosphorus concentrations occurred because phosphorus is transported with sediment in Cedar Creek to Lake Olathe. However, upon reaching Lake Olathe, the sediment-adsorbed phosphorus settles onto the lakebed sediment in Lake Olathe and is temporarily unavailable to the epilimnion.

Maximum concentrations of orthophosphate and total phosphorus in the hypolimnion of Lake Olathe were larger than those in the epilimnion of Lake Olathe. This indicates that internal loading, the release of sediment-adsorbed phosphorus into the water column, occurred in Lake Olathe. Mean and median hypolimnetic orthophosphate concentrations in Lake Olathe were larger than in Cedar Creek; however, mean and median total phosphorus concentrations were slightly larger in Cedar Creek than in the hypolimnion of Lake Olathe, most likely because of the larger amounts of suspended sediment and, thus, adsorbed phosphorus in the water column (table 4).

The following regression models were developed for orthophosphate and total phosphorus in both Cedar Creek (table 5) and the epilimnion of Lake Olathe (table 6): 
Table 6. Summary of regression model equations for selected constituents in water from epilimnion of Lake Olathe near dam (site 2), northeast Kansas, $2000-02$.

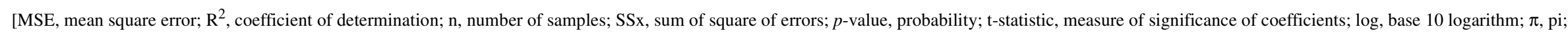

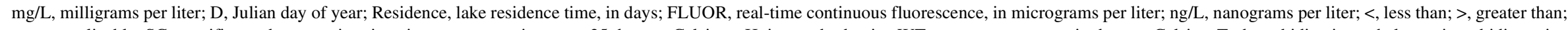

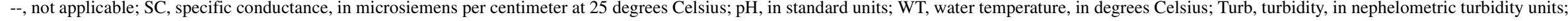
TKN, ammonia plus organic nitrogen as nitrogen, in milligrams per liter; Secchi, Secchi transparency depth, in feet]

\begin{tabular}{|c|c|c|c|c|c|c|c|c|c|}
\hline Constituent (unit of measurement) & $\begin{array}{l}\text { Range in } \\
\text { concen- } \\
\text { tration }\end{array}$ & Equation & MSE & $R^{2}$ & $\mathrm{n}$ & SSx & $p$-value & $\begin{array}{l}\mathrm{t}- \\
\text { stati- } \\
\text { stic }\end{array}$ & $\begin{array}{c}\text { Bias } \\
\text { cor- } \\
\text { rec- } \\
\text { tion } \\
\text { factor } \\
\text { (Duan, } \\
\text { 1983) }\end{array}$ \\
\hline Sodium (NA) (mg/L) & $26-48$ & $\mathrm{NA}=0.09 \mathrm{SC}+8.8 \mathrm{pH}-80$ & 5.09 & 0.94 & 11 & 40.7 & $<0.001$ & $>2$ & -- \\
\hline Chloride (CL) (mg/L) & $27-77$ & $\mathrm{CL}=0.176 \mathrm{SC}-42.32$ & 24.26 & .92 & 11 & 218 & $<.001$ & $>2$ & -- \\
\hline Ammonia, as nitrogen $(\mathrm{TA})(\mathrm{mg} / \mathrm{L})$ & $0.02-0.27$ & $\log \mathrm{TA}=-0.31 \log \mathrm{WT}+0.002$ Residence -0.05 & .003 & .86 & 14 & .03 & $<.001$ & $>2$ & 1.01 \\
\hline $\begin{array}{l}\text { Nitrite plus nitrate, as nitrogen (TIN) } \\
(\mathrm{mg} / \mathrm{L})\end{array}$ & $0.05-2.4$ & $\mathrm{TIN}=0.0261 \mathrm{Turb}+0.0039 \mathrm{SC}-0.0278 \mathrm{WT}-1.6385$ & .043 & .94 & 15 & .47 & .009 & $>2$ & -- \\
\hline $\begin{array}{l}\text { Nitrite plus nitrate, as nitrogen (TIN) } \\
(\mathrm{mg} / \mathrm{L})\end{array}$ & $0.05-2.4$ & $\mathrm{TIN}=1.25 \log ($ Turb $)+(0.67 \sin 2 \pi \mathrm{D}+0.57 \cos 2 \pi \mathrm{D})-0.87$ & .082 & .89 & 15 & .90 & $<.001$ & $>2$ & -- \\
\hline $\begin{array}{l}\text { Phosphate, ortho, as phosphorus (OP) } \\
(\mathrm{mg} / \mathrm{L})\end{array}$ & $0.01-0.04$ & $\mathrm{OP}=0.0024 \sin 4 \pi \mathrm{D}-0.0049 \cos 4 \pi \mathrm{D}+0.0006 \mathrm{FLUOR}+0.0002 \mathrm{Turb}+0.0074$ & .00001 & .91 & 15 & .0001 & $<.001$ & $>2$ & -- \\
\hline $\begin{array}{l}\text { Phosphorus, total, as phosphorus (TP) } \\
(\mathrm{mg} / \mathrm{L})\end{array}$ & $0.04-0.14$ & $\mathrm{TP}=0.0007($ Residence $)-0.0442 \mathrm{pH}+0.39$ & .00008 & .93 & 15 & .001 & $<.001$ & $>2$ & -- \\
\hline $\begin{array}{l}\text { Melosira granulata (MELGRA) (relative } \\
\text { percentage abundance) }\end{array}$ & $0-26.7$ & MELGRA $=(12.61 \cos 2 \pi \mathrm{D} / 365+0.17 \sin 2 \pi \mathrm{D} / 365)-0.21$ Residence $+0.22 \mathrm{Turb}+14.08$ & 15.44 & .89 & 15 & 154.43 & $<.001$ & $>2$ & -- \\
\hline $\begin{array}{l}\text { Oscillatoria sp. (OSCISP) (relative } \\
\text { percentage abundance) }\end{array}$ & $0-2.52$ & OSCISP $=0.06$ Turb -0.03 Residence $+2.97(\mathrm{TKN})-2.54$ & .37 & .75 & 15 & 4.07 & .001 & $>2$ & -- \\
\hline $\begin{array}{l}\text { Cryptomonas sp. (CRYPTSPP) (relative } \\
\text { percentage abundance) }\end{array}$ & $0-50.2$ & $\begin{array}{l}\text { CRYPTSPP }=(20.81 \sin 2 \pi \mathrm{D} / 365+22.87 \cos 2 \pi \mathrm{D} / 365)-285.8 \log (\mathrm{SC})+30.1(\mathrm{FLUOR})+ \\
\quad 758\end{array}$ & 81.6 & .73 & 15 & 816 & .007 & $>2$ & -- \\
\hline $\begin{array}{l}\text { Anabaena sp. (ANABSPP) (relative } \\
\text { percentage abundance) }\end{array}$ & $0-47.2$ & ANABSPP $=0.66$ Turb $-0.16 \mathrm{SC}-58.99(\mathrm{TKN})+125.2$ & 136 & .64 & 14 & 1,360 & .014 & $>2$ & -- \\
\hline Geosmin (ng/L) & $2.5-12$ & Geosmin $=1.08$ Secchi $-0.064 \mathrm{SC}+0.24 \mathrm{Turb}+31.04$ & 3.41 & .70 & 16 & 40.9 & .0016 & $>2$ & -- \\
\hline
\end{tabular}




\author{
Cedar Creek OP $=0.0002 Q+0.022$; \\ Cedar Creek $\log \mathrm{TP}=0.0009 \mathrm{SSC}-0.96$; \\ Cedar Creek TP = 0.29logTurb -0.35 ; \\ Lake Olathe $\mathrm{OP}=0.0024 \sin 4 \pi \mathrm{D}-0.0049 \cos 4 \pi \mathrm{D}+$ \\ 0.0006 FLUOR +0.0002 Turb $+0.0074 ;$ and \\ Lake Olathe $\mathrm{TP}=0.0007($ Residence $)-0.0442 \mathrm{pH}+0.39 ;(10)$
}

where

OP is orthophosphate concentration, in milligrams per liter;

$\mathrm{TP}$ is total phosphorus concentration, in milligrams per liter;

Q is discharge, in cubic feet per second;

SSC is suspended-sediment concentration, in milligrams per liter;

$\sin 4 \pi \mathrm{D}-\cos 4 \pi \mathrm{D}$ is a seasonality term based on time of year, in days ( $\mathrm{D}$ is Julian day, where January 1 is 1 and December 31 is 365 );

FLUOR is real-time continuous fluorescence, in micrograms per liter;

Turb is turbidity, in nephelometric turbidity units;

Residence is number of days Lake Olathe elevation was less than $937.5 \mathrm{ft}$ prior to sampling, in days; and

$\mathrm{pH}$ is negative log of hydrogen ion concentration, in standard units.

The coefficient of determination $\left(\mathrm{R}^{2}\right)$ and $p$-values for these models (equations 6-10) varied from 0.58 to 0.93 and less than 0.001 to 0.003 , respectively, indicating there was a good statistical relation between orthophosphate and total phosphorus and the selected explanatory variables (tables 5 and 6 ). Equations 6-10 are valid within the concentration ranges presented in tables 5 and 6.

The regression models developed for Cedar Creek (table 5) for orthophosphate and total phosphorus rely on discharge and suspended-sediment concentration, respectively. This is consistent with the known behavior of these chemicals; dissolved orthophosphate would be transported more readily in solution, and total phosphorus more likely would attach to sediment particles and be related to suspended-sediment concentration.

The orthophosphate and total phosphorus models developed for Lake Olathe (table 6) include a time component that is a function of the time of year and length of time there has been no outflow from the lake. As stated previously, seasonal fertilizer application (and other sources) combined with discharge from Cedar Creek contribute to elevated orthophosphate concentrations in Lake Olathe. The largest application of phosphorus chemicals in the Lake Olathe watershed occurs during the spring and early summer months when chemicals are applied to crops and residential lawns. The relation of residence time to total phosphorus concentration in Lake Olathe, although small, may be a function of internal loading, which results when phosphorus released from bottom sediment contributes to the total phosphorus concentration in the lake, especially during periods when there is no outflow.

\section{Selected Trace Elements}

Three trace elements, boron, iron, and manganese, were analyzed in water samples collected from Cedar Creek and Lake Olathe. Trace elements occur naturally in ground water and surface water in the United States at concentrations of parts per billion (or micrograms per liter). The presence of geologic materials (rocks, sand, and soil) are natural sources of trace elements. In addition, human-related sources and minerals containing trace elements can affect the quality of ground and surface water.

Boron is a light element, tends to be volatile, and is an essential micronutrient for plant growth (Hem, 1992, p. 129). Concentrations of boron larger than $1 \mathrm{mg} / \mathrm{L}$ can be toxic to some plant species (Hem, 1992, p. 129). Boron commonly is distributed in igneous rocks, and ocean water concentrations of this element are about $4.6 \mathrm{mg} / \mathrm{L}$. Currently (2004), USEPA and KDHE have no established public health criteria for boron.

Iron and manganese are essential constituents of many enzymatic and cellular processes including photosynthesis. However, increased concentrations can adversely affect the taste and odor of drinking water, and USEPA has established SDWRs of $300 \mu \mathrm{g} / \mathrm{L}$ for total iron and $50 \mu \mathrm{g} / \mathrm{L}$ for total manganese, which apply to treated drinking water (U.S. Environmental Protection Agency, 2003). Total concentrations of iron and manganese consist of both particulate and dissolved forms.

Dissolved forms of boron, iron, and manganese were measured in water samples from Cedar Creek and Lake Olathe (table 7). Median dissolved boron concentrations ranged from $140 \mu \mathrm{g} / \mathrm{L}$ in Cedar Creek to $90 \mu \mathrm{g} / \mathrm{L}$ in the epilimnion at site 2 and at site 3 at Lake Olathe. Median dissolved iron concentrations in Cedar Creek were less than the USEPA SDWR for treated drinking water, with concentrations ranging from less than 10 to $10 \mu \mathrm{g} / \mathrm{L}$. The median dissolved iron concentration in samples from the hypolimnion of Lake Olathe (site 2) was $110 \mu \mathrm{g} / \mathrm{L}$, and concentrations ranged from less than 10 to $210 \mu \mathrm{g} / \mathrm{L}$, substantially less than the USEPA SDWR for treated drinking water. Particulate forms of iron, defined as the iron attached to organic material, were not measured in water samples from Cedar Creek or Lake Olathe; however, particulate iron concentrations in lakes generally are on the order of $1 \mathrm{mg} / \mathrm{L}$, most of which is contained in the lake biota (Horne and Goldman, 1994). The median concentration of epilimnetic dissolved manganese in Lake Olathe (site 2) was less than $1 \mu \mathrm{g} / \mathrm{L}$ compared to the hypolimnetic median concentration of $1,400 \mu \mathrm{g} / \mathrm{L}$. Concentrations in samples from the lake ranged from less than 1 to about $270 \mu \mathrm{g} / \mathrm{L}$ in the epiliminion. The largest concentrations were detected near the bottom of the lake consistent with small dissolved oxygen concentrations and 
Table 7. Statistical summary describing selected trace-element concentrations in water from Cedar Creek at Highway 56 and Lake 01 athe, northeast Kansas, $2000-02$.

[SDWR, Secondary Drinking Water Regulation (U.S. Environmental Protection Agency, 2003); <, less than; --, not applicable]

\begin{tabular}{|c|c|c|c|c|c|c|c|}
\hline \multirow{2}{*}{$\begin{array}{c}\text { Trace element } \\
\text { (unit of measure) }\end{array}$} & \multirow{2}{*}{$\begin{array}{l}\text { Number of } \\
\text { samples }\end{array}$} & \multicolumn{6}{|c|}{ Concentration, in micrograms per liter } \\
\hline & & Minimum & Maximum & Mean & Median & Standard deviation & $\begin{array}{c}\text { Water-quality } \\
\text { criteria }^{1}\end{array}$ \\
\hline \multicolumn{8}{|c|}{ Cedar Creek at Highway 56 (site 1, fig. 1) } \\
\hline Boron & 8 & 60 & 220 & 130 & 140 & 50 & -- \\
\hline Iron & 8 & $<10$ & 10 & 10 & 10 & $<10$ & 300 (SDWR) \\
\hline Manganese & 6 & $<1$ & 200 & 100 & 97 & 74 & 50 (SDWR) \\
\hline \multicolumn{8}{|c|}{ Lake Olathe near dam (site 2, fig. 1) } \\
\hline \multicolumn{8}{|l|}{ Boron } \\
\hline epilimnion & 13 & 80 & 100 & 90 & 90 & 10 & -- \\
\hline hypolimnion & 11 & 50 & 100 & 80 & 80 & 10 & -- \\
\hline \multicolumn{8}{|l|}{ Iron } \\
\hline epilimnion & 13 & $<10$ & $<10$ & $<10$ & $<10$ & $<10$ & 300 (SDWR) \\
\hline hypolimnion & 10 & $<10$ & 210 & 110 & 110 & 60 & 300 (SDWR) \\
\hline \multicolumn{8}{|l|}{ Manganese } \\
\hline epilimnion & 12 & $<1$ & 270 & 30 & $<1$ & 78 & 50 (SDWR) \\
\hline hypolimnion & 9 & 1 & 3,100 & 1,400 & 1,400 & 1,300 & 50 (SDWR) \\
\hline \multicolumn{8}{|c|}{ Lake Olathe at upstream end (site 3 , fig. 1) } \\
\hline Boron & 5 & 70 & 100 & 90 & 90 & 10 & -- \\
\hline Iron & 5 & $<10$ & 20 & 20 & 20 & -- & 300 (SDWR) \\
\hline Manganese & 3 & $<1$ & 23 & 8 & $<1$ & 13 & 50 (SDWR) \\
\hline
\end{tabular}

\footnotetext{
${ }^{1}$ The Secondary Drinking Water Regulation is a standard that applies to treated drinking water.
} 


\section{Surface-Water-Quality Conditions and Relation to Taste-and-Odor Occurrences in the Lake Olathe Watershed, Northeast Kansas, 2000-02}

reducing conditions. Smaller concentrations were detected near the dam, and the city of Olathe water-treatment process results in concentrations in drinking water considerably less than the USEPA SDWR (U.S. Environmental Protection Agency, 2003).

\section{Selected Pesticides}

Agricultural cropland and grassland constitute more than 80 percent of the land cover in the Lake Olathe watershed, and pesticides likely have been used on the croplands to control weeds, insects, and other pests to maximize crop yields. Pesticides include herbicides, insecticides, and fungicides, and about three-fourths of the United States total annual pesticide usage is for agriculture (Aspelin and others, 1992). In 1991, about 84 percent of the pesticides applied in the United States were herbicides (U.S. Department of Agriculture, 1992; Meade, 1995). The use of pesticides may be of concern because of the potential adverse effects that pesticides can have on aquatic organisms as well as on humans who rely on Lake Olathe for their drinking-water supply.

Fifty pesticides were analyzed in water samples from Cedar Creek and Lake Olathe. Of those 50, 10 pesticides were detected at concentrations greater than $0.01 \mu \mathrm{g} / \mathrm{L}$ in Cedar Creek, and 9 pesticides were detected at concentrations greater than $0.01 \mu \mathrm{g} / \mathrm{L}$ in the epilimnion of Lake Olathe (table 8). Seven pesticides were detected in water samples from Cedar Creek at concentrations greater than $0.10 \mu \mathrm{g} / \mathrm{L}$, and four pesticides or their degradation products were detected in Cedar Creek at concentrations greater than $1.0 \mu \mathrm{g} / \mathrm{L}$ (acetochlor, atrazine, deethylatrazine, and metolachlor). The detected pesticides were primarily herbicides (or their degradation products) used in the control of broadleaf weeds and grasses. However, diazinon, an insecticide used on a variety of crops and for residential control of various insects, also was detected frequently at small concentrations.

Concentrations of atrazine were analyzed using ELISA and confirmed with GC/MS methods. The coefficient of determination, $\mathrm{R}^{2}$, between the two methods for atrazine was 0.87 ( $p$-value $=$ less than 0.001$)$, indicating a statistically significant relation between the two methods of analysis (fig. 8).

Therefore, data from the ELISA method, a more rapid analysis, are reported herein.

Regression analysis was used to estimate the concentration of atrazine in Cedar Creek from surrogate continuous real-time water-quality variables. Of the six continuous real-time waterquality variables, the best regression model was developed for atrazine using discharge and turbidity as independent variables (table 5). The coefficient of determination, $\mathrm{R}^{2}$, and $p$-value were 0.92 and less than 0.001 , respectively, indicating a statistically significant relation between the variables. The resulting equation:

$$
\mathrm{ATR}=0.0192 \mathrm{Q}-0.003 \text { Turb }+1.075 \text {, }
$$

where
ATR is the concentration of atrazine, in micrograms per liter;

Q is stream discharge, in cubic feet per second; and

Turb is continuous turbidity, in nephelometric turbidity units;

showed a positive relation between atrazine and discharge, and a slightly negative relation between atrazine and turbidity. On the basis of equation 11, atrazine concentrations would increase with discharge in Cedar Creek, but concentrations would decrease slightly with increased turbidity.

Pesticide detection frequency for Cedar Creek and Lake Olathe were compared to preliminary data results from a national data set of about 75 stream sites in 49 river basins throughout the country that drained primarily agricultural land (fig. 9) (U.S. Geological Survey, 2001). Acetochlor, alachlor, atrazine, deethylatrazine, metolachlor, and simazine are all preemergent herbicides, or their degradation products, applied to corn, grain sorghum, and other crops and were detected at concentrations greater than $0.01 \mu \mathrm{g} / \mathrm{L}$ in Cedar Creek, 20 to 64 percent more frequently than were detected in the national data set. Concentrations of these compounds were detected 9 to 65 percent more frequently in Lake Olathe than in the national data set at concentrations greater than $0.01 \mu \mathrm{g} / \mathrm{L}$. At concentrations greater than $0.10 \mu \mathrm{g} / \mathrm{L}$, these same six compounds were detected 5 to 57 percent more frequently in Cedar Creek than in the national data set. In particular, at concentrations greater than $0.10 \mu \mathrm{g} / \mathrm{L}$, atrazine and its degradate compound deethylatrazine were detected 50 percent more frequently in Cedar Creek than in the national data set. The higher detection frequency in samples from Cedar Creek than in the national data set may indicate greater corn or grain sorghum production or herbicide use or transport in the Lake Olathe watershed than in other agricultural watersheds in the country that were part of the national data set. Three of the pesticides, acetochlor, alachlor, and metolachlor, are only slightly soluble in water and, therefore, not very mobile. Transport of these pesticides through the watershed would occur adsorbed to sediment, probably during and after periods of storm runoff. However, the frequency of detection of these pesticides in Cedar Creek was between 33 and 56 percent greater than the national data set, suggesting either greater use of these chemicals or greater sediment transport in the Lake Olathe watershed than in the sampled agricultural watersheds represented by the national data set.

Concentrations of pesticides varied with streamflow but were persistent during both low-flow and high-flow conditions. Maximum concentrations of all 11 pesticides in Cedar Creek occurred during storm flows, indicating that the pesticides generally are transported by surface runoff. Streamflow in Cedar Creek occurs primarily during the late winter (January 1 through March 31) and spring (April 1 through June 30), coinciding with the application of pesticides, and usually is dry or flows at less than $1 \mathrm{ft}^{3} / \mathrm{s}$ through the summer (July 1 through September 30) and fall (October 1 through December 31). Therefore, it was not possible to determine whether pesticides were persistent in the stream throughout the year. 
Table 8. Statistical summary describing selected pesticide concentrations in water from Cedar Creek at Highway 56 and Lake 0lathe, northeast Kansas, $2000-02$.

[MCL, Maximum Contaminant Level (U.S. Environmental Protection Agency, 2003); ELISA, enzyme-linked immunosorbent assay; <, less than; --, not applicable]

\begin{tabular}{|c|c|c|c|c|c|c|c|}
\hline \multirow[b]{2}{*}{ Pesticide } & \multicolumn{7}{|c|}{ Concentration, in micrograms per liter } \\
\hline & $\begin{array}{l}\text { Number of } \\
\text { samples }\end{array}$ & Minimum & Maximum & Mean & Median & Standard deviation & $\begin{array}{c}\text { Water-quality } \\
\text { criteria }{ }^{1}\end{array}$ \\
\hline \multicolumn{8}{|c|}{ Cedar Creek at Highway 56 (site 1, fig. 1) } \\
\hline Acetochlor & 8 & $<0.004$ & 1.07 & 0.477 & 0.308 & 0.448 & -- \\
\hline Alachlor & 8 & $<.002$ & .494 & .208 & .134 & .22 & 2.0 (MCL) \\
\hline Atrazine (ELISA) & 14 & .10 & 10 & 2.1 & .41 & 3.27 & 3.0 (MCL) \\
\hline Deethylatrazine & 8 & .019 & 1.37 & .453 & .277 & .475 & -- \\
\hline Diazinon & 5 & $<.005$ & .039 & .026 & .026 & .012 & -- \\
\hline Metolachlor & 8 & .036 & 1.27 & .451 & .148 & .517 & -- \\
\hline Metribuzin & 8 & $<.006$ & .120 & .07 & .070 & .044 & -- \\
\hline Prometon & 8 & .005 & .045 & .024 & .025 & .015 & -- \\
\hline Simazine & 8 & $<.011$ & .110 & .036 & .020 & .042 & 4.0 (MCL) \\
\hline Tebuthiuron & 5 & .004 & .015 & .012 & .015 & .006 & -- \\
\hline \multicolumn{8}{|c|}{ Lake Olathe near dam (site 2, fig. 1) } \\
\hline \multicolumn{8}{|l|}{ Acetochlor } \\
\hline epilimnion & 6 & $<.004$ & .322 & .123 & .087 & .114 & -- \\
\hline hypolimnion & 3 & .014 & .770 & .367 & .318 & .380 & -- \\
\hline \multicolumn{8}{|l|}{ Alachlor } \\
\hline epilimnion & 6 & $<.002$ & .029 & .018 & .018 & .012 & 2.0 (MCL) \\
\hline hypolimnion & 3 & .006 & .111 & .058 & .058 & .074 & 2.0 (MCL) \\
\hline \multicolumn{8}{|l|}{ Atrazine (ELISA) } \\
\hline epilimnion & 16 & .43 & 4.3 & 1.9 & 1.7 & 1.23 & 3.0 (MCL) \\
\hline hypolimnion & 11 & .25 & 5.0 & 1.9 & 1.0 & 1.64 & 3.0 (MCL) \\
\hline \multicolumn{8}{|l|}{ Deethylatrazine } \\
\hline epilimnion & 6 & .093 & .417 & .206 & .178 & .125 & -- \\
\hline hypolimnion & 3 & .168 & .590 & .355 & .306 & .215 & -- \\
\hline \multicolumn{8}{|l|}{ Diazinon } \\
\hline epilimnion & 6 & .005 & .037 & .017 & .013 & .012 & -- \\
\hline hypolimnion & 2 & .003 & .015 & .009 & .009 & .009 & -- \\
\hline
\end{tabular}


Table 8. Statistical summary describing selected pesticide concentrations in water from Cedar Creek at Highway 56 and Lake 0lathe, northeast Kansas, 2000-02.-Continued

[MCL, Maximum Contaminant Level (U.S. Environmental Protection Agency, 2003); ELISA, enzyme-linked immunosorbent assay; <, less than; --, not applicable]

\begin{tabular}{|c|c|c|c|c|c|c|c|}
\hline \multirow[b]{2}{*}{ Pesticide } & \multicolumn{7}{|c|}{ Concentration, in micrograms per liter } \\
\hline & $\begin{array}{l}\text { Number of } \\
\text { samples }\end{array}$ & Minimum & Maximum & Mean & Median & Standard deviation & $\begin{array}{c}\text { Water-quality } \\
\text { criteria }^{1}\end{array}$ \\
\hline Metolachlor & \multicolumn{7}{|c|}{ Lake Olathe near dam (site 2, fig. 1)—Continued } \\
\hline epilimnion & 6 & 0.07 & 0.86 & 0.37 & 0.29 & 0.30 & -- \\
\hline hypolimnion & 3 & .23 & .88 & .46 & .27 & .36 & -- \\
\hline \multicolumn{8}{|l|}{ Metribuzin } \\
\hline epilimnion & 6 & $<.006$ & $<.050$ & -- & -- & -- & -- \\
\hline hypolimnion & 3 & .042 & .042 & .042 & .042 & -- & -- \\
\hline \multicolumn{8}{|l|}{ Prometon } \\
\hline epilimnion & 6 & $<.011$ & .036 & .024 & .026 & .011 & -- \\
\hline hypolimnion & 3 & .026 & .040 & .033 & .033 & .010 & -- \\
\hline \multicolumn{8}{|l|}{ Simazine } \\
\hline epilimnion & 6 & .009 & .061 & .019 & .012 & .021 & 4.0 (MCL) \\
\hline hypolimnion & 3 & .007 & .054 & .031 & .031 & .033 & 4.0 (MCL) \\
\hline \multicolumn{8}{|l|}{ Tebuthiuron } \\
\hline epilimnion & 6 & .011 & $<.016$ & .011 & .011 & -- & -- \\
\hline hypolimnion & 2 & .013 & .016 & .014 & .014 & .002 & -- \\
\hline \multicolumn{8}{|c|}{ Lake Olathe at upstream end (site 3 , fig. 1) } \\
\hline Acetochlor & 4 & .038 & .107 & .071 & .07 & .032 & -- \\
\hline Alachlor & 4 & $<.002$ & .04 & .031 & .031 & .009 & $2.0(\mathrm{MCL})$ \\
\hline Atrazine (ELISA) & 6 & .39 & 4.2 & 1.9 & 1.6 & 1.5 & 3.0 (MCL) \\
\hline Deethylatrazine & 4 & .186 & .390 & .27 & .253 & .092 & -- \\
\hline Diazinon & 4 & .006 & .013 & .009 & .008 & .003 & -- \\
\hline Metolachlor & 4 & .162 & .606 & .295 & .205 & .209 & -- \\
\hline Prometon & 4 & .025 & .037 & .029 & .028 & .005 & -- \\
\hline Simazine & 4 & .009 & .054 & .021 & .011 & .022 & 4.0 (MCL) \\
\hline Tebuthiuron & 4 & .013 & .015 & .014 & .014 & .002 & -- \\
\hline
\end{tabular}

${ }^{1}$ The Maximum Contaminant Level (MCL) is a standard that applies to treated drinking water. 
$p$-value less than 0.001
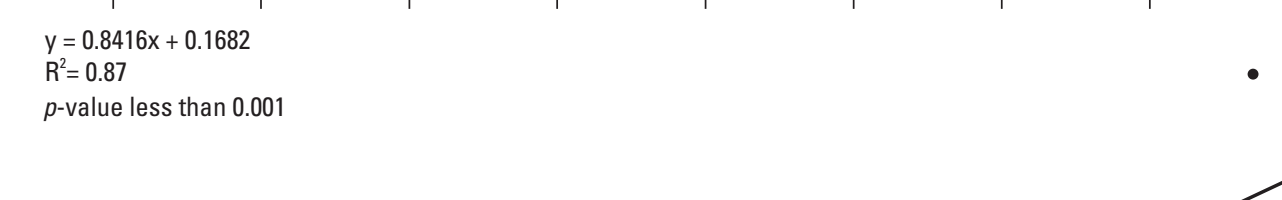


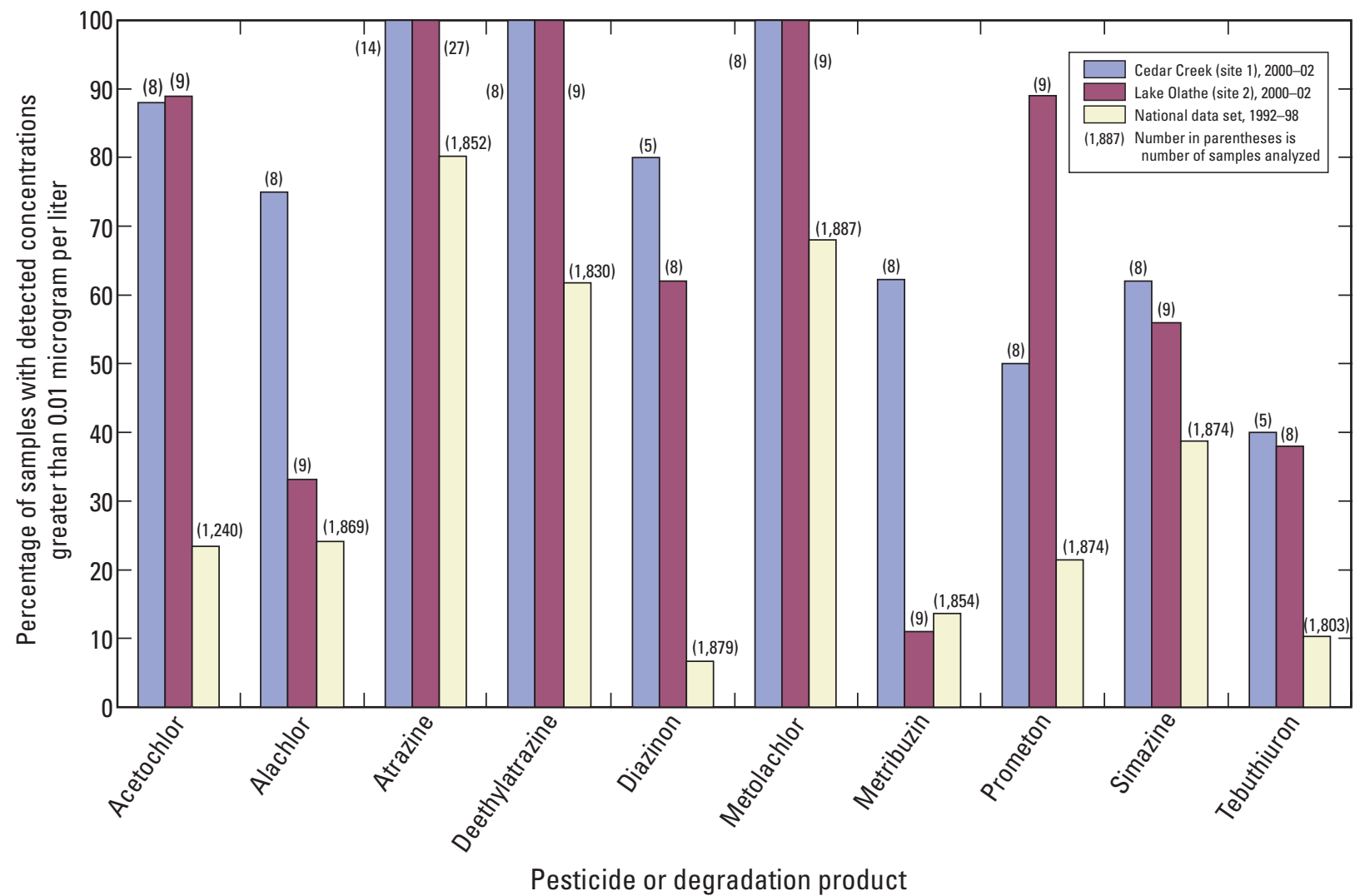

Figure 9. Detection frequency of selected pesticide compounds in water from Cedar Creek at Highway 56 and Lake Olathe near dam (site 2), 2000-02, at concentrations greater than or equal to 0.01 microgram per liter. Location of sampling sites shown in figure 1.

\section{Estimated Sediment and Nutrient Loads}

The total suspended-sediment load transported to the lake during 2001 ( 2.85 million $\mathrm{lb}$ ) was one-fourth the 45 -year annual average lake bottom-sediment deposition, 12.6 million $\mathrm{lb}$, estimated on the basis of the lake-bottom sediment analysis done in 2000 (Mau, 2002). Suspended-sediment load estimates for 2002 were nine times less than the 45 -year average. In addition, the sediment load during 2001 was significantly less than the 45-year average load estimated on the basis of the lake-bottom sediment analysis (Mau, 2002), which suggests either there are other sediment transport mechanisms not accounted for (recent total phosphorus concentrations are higher than the average historic concentrations) or that sediment is not transported uniformly from year to year. Large, intermittent storm runoff likely transports the majority of sediment, and this storm runoff may not have occurred in 2001 or 2002 to the extent it does during an average year.

Nitrogen and phosphorus generally are associated with sediment loads that are transported from streams to reservoirs. Found primarily with finer sediment fractions, the incorporation of phosphorus into sediment effectively removes phosphorus from the water column, and the reservoir sediment becomes the primary sink or trap for phosphorus (Morris and Fan, 1998, p. 4.18). The computation of nutrient loads showed that the major contributors of nutrients from Cedar Creek to Lake Olathe were related to various forms of nitrogen (table 9). The fraction of nitrogen that is typically organic (TKN) represented nearly 50 percent of the total nutrient load to Lake Olathe during 2001 and 2002 (45 and 47 percent, respectively) (table 9). The fraction of nitrogen that is soluble and represented by nitrite plus nitrate (TIN) also accounted for nearly 50 percent of the total nutrient load to Lake Olathe during 2001 and 2002 (48 and 45 percent, respectively). Total nitrogen, the sum of the fractions of TIN and TKN, represented more than 90 percent of the total nutrient load (by mass) delivered to Lake Olathe during 2001 and 2002, whereas total phosphorus represented only about 7 and 8 percent of the total nutrient load for the same periods (table 9). The wide range in values of the various forms of nitrogen in 2001 and 2002 probably are the result of differences in streamflow. The nitrogen regression equations used to make the estimates are linked to streamflow and turbidity, both of which were greater in 2001 than in 2002.

Nutrient loads were largest during spring (April-June) 2001 and 2002 when fertilizers and pesticides are applied to agricultural and residential land and the greatest amount of seasonal precipitation and runoff occurs (fig. 11). In addition, total streamflow measured at Cedar Creek at Highway 56 at Olathe, Kansas, was, as previously stated, three times larger in calendar year 2001 than 2002 (table 9). Streamflow serves as the 


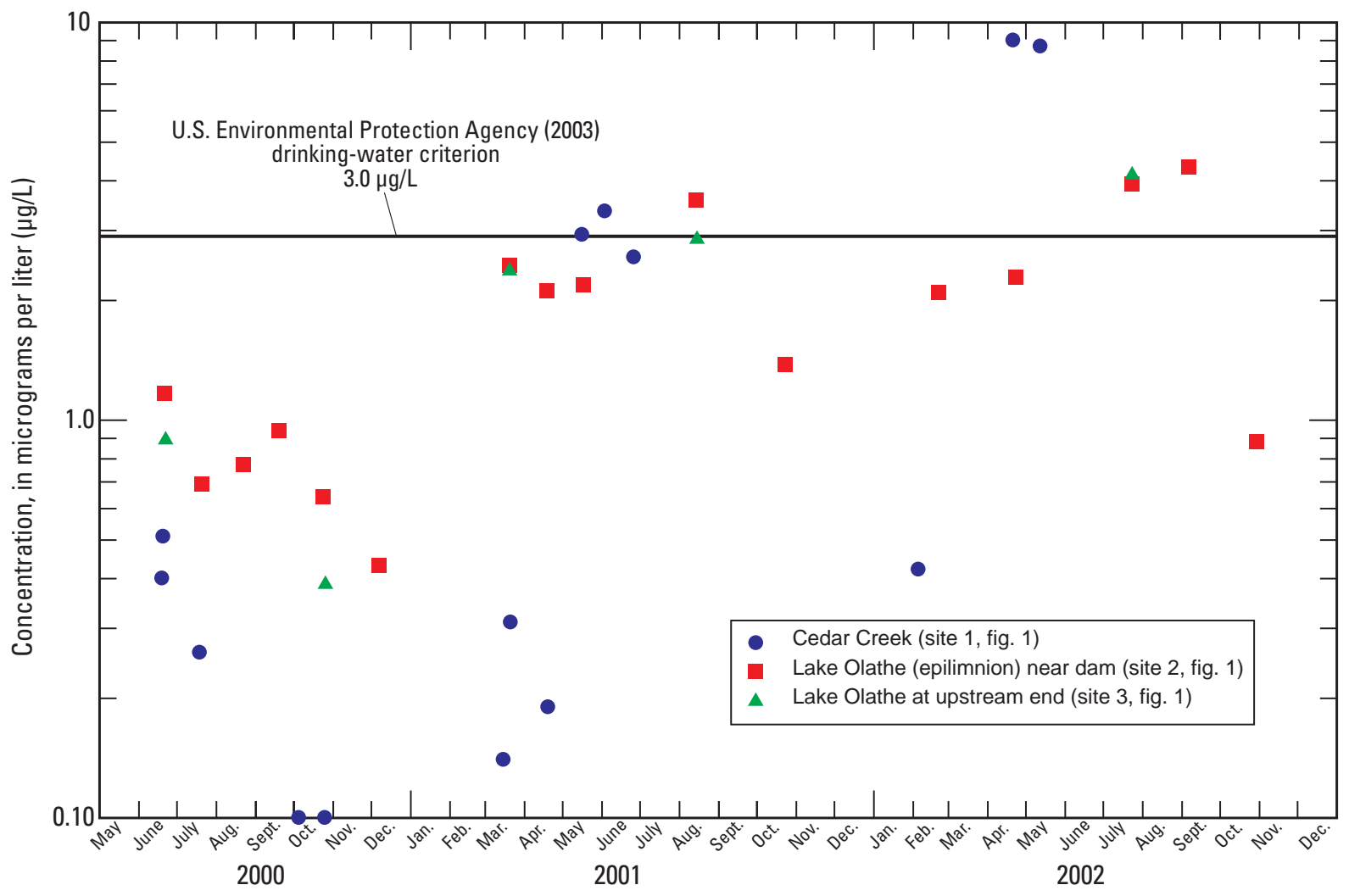

Figure 10. Concentrations of atrazine in water samples collected from Cedar Creek at Highway 56 and Lake Olathe, 2000-02. Location of sampling sites shown in figure 1.

transport mechanism for nutrient loading to Lake Olathe. Approximately 60 percent of the total annual nutrient load for total nitrogen and total phosphorus occurred during spring 2001, the months of April through June (table 9). Similarly, in 2001, about 57 percent of the TKN load occurred during the spring months. In 2002, 88 percent of the TKN load occurred during the spring months, and about 89 and 95 percent of the total nitrogen loads and total phosphorus loads, respectively, occurred during the same months. The total phosphorus load transported to Lake Olathe during $2001(10,700 \mathrm{lb})$ was similar to the 45-year average phosphorus load contributed to the lake estimated on the basis of the lake-bottom sediment analysis done in $2000(9,720 \mathrm{lb})$ (Mau, 2002). However, the total phosphorus load transported to Lake Olathe during $2002(3,890 \mathrm{lb})$ was considerably less than the 45 -year average and may be indicative of less precipitation and sediment transport in 2002 compared to an average year.

Orthophosphate, the most available form of phosphate, is the soluble, inorganic fraction of phosphorus that is taken up directly by plant cells. A statistically significant correlation existed between stream discharge, $\mathrm{Q}$, and orthophosphate (OP) that resulted in a coefficient of determination, $\mathrm{R}^{2}$, of 0.83 (table 5). Typically, the orthophosphate fraction represents 10 percent or less of the total phosphorus in natural streams and lakes (Wetzel, 2001). However, at Cedar Creek, depending on the season, orthophosphate represented 21 to 67 percent of the total phosphorus load (table 9). The mean percentage of total phosphorus load represented by orthophosphate for 2001-02 was 29 percent, indicating that either the regression model overestimated the orthophosphate load or that there are large sources of soluble phosphorus in the Lake Olathe watershed. This is significant because the watershed provided a large continuous nutrient supply for algae that could have led to algal blooms and subsequent taste-and-odor occurrences in drinking water. Large percentage orthophosphate loads determined in the Lake Olathe watershed also have been identified in other watersheds in the United States (Meyer and Likens, 1979; Sullivan, 1999; Journey and Gill, 2001). Source areas of orthophosphate in Cedar Creek were not investigated as part of this study but are probably nonpoint-source related to livestock or septic systems.

The significance of nonpoint and point sources on water quality can be evaluated by comparing the statistical significance of the streamflow regression coefficient (Journey and Gill, 2001). A significant, positive relation between streamflow and nutrient concentration indicates that nonpoint sources are the primary source of input, provided ground-water contributions of nutrients are negligible. This is a result of contributions from overland flow due to increased runoff from precipitation that also increased discharge. If the relation is negative, nutrient point sources are the primary source of input. For example, the regression equation for Cedar Creek for orthophosphate: 
Table 9. Summary of estimated seasonal and annual loads of suspended sediment and nutrient loads in Cedar Creek at Highway 56,0 lathe, northeast Kansas, 2001-02.

[Loads are rounded to three significant figures.]

\begin{tabular}{|c|c|c|c|c|c|c|c|c|c|}
\hline \multirow[b]{2}{*}{ Season } & \multirow[b]{2}{*}{$\begin{array}{c}\text { Total } \\
\text { discharge } \\
\text { (acre-feet) }\end{array}$} & \multicolumn{8}{|c|}{ Estimated load, in pounds } \\
\hline & & $\begin{array}{c}\text { Total } \\
\text { suspended } \\
\text { sediment }\end{array}$ & $\begin{array}{c}\text { Ammonia, as } \\
\text { nitrogen }\end{array}$ & $\begin{array}{c}\text { Ammonia plus } \\
\text { organic } \\
\text { nitrogen } \\
\text { (TKN), as } \\
\text { nitrogen }\end{array}$ & $\begin{array}{c}\text { Nitrite plus } \\
\text { nitrate (TIN), } \\
\text { as nitrogen }\end{array}$ & $\begin{array}{l}\text { Total nitrogen } \\
\text { (TKN plus TIN) }\end{array}$ & $\begin{array}{l}\text { Phosphate, } \\
\text { ortho (OP), as } \\
\text { phosphorus }\end{array}$ & $\begin{array}{l}\text { Phosphorus, } \\
\text { total (TP), as } \\
\text { phosphorus }\end{array}$ & $\begin{array}{l}\text { Total nutrient } \\
\text { load (actual) }\end{array}$ \\
\hline Winter (Jan. - Mar.) 2001 & 2,590 & 413,000 & 6,600 & 8,950 & 11,200 & 20,100 & 496 & 735 & 20,800 \\
\hline Winter (Jan. - Mar.) 2002 & 657 & 179,000 & 1,390 & 2,050 & 1,820 & 3,900 & 67 & 123 & 4,020 \\
\hline Spring (Apr. - June) 2001 & 4,740 & $1,370,000$ & 27,200 & 37,800 & 43,200 & 81,000 & 2,200 & 6,850 & 87,800 \\
\hline Spring (Apr. - June) 2002 & 2,750 & 974,000 & 10,000 & 19,800 & 19,500 & 39,300 & 958 & 3,710 & 43,000 \\
\hline Summer (July - Sept.) 2001 & 3,350 & 892,000 & 8,430 & 17,000 & 13,900 & 30,900 & 605 & 2,840 & 33,700 \\
\hline Summer (July - Sept.) 2002 & 25 & 36,900 & 51 & 78 & 63 & 141 & 2 & 3 & 144 \\
\hline Fall (Oct. - Dec.) 2001 & 616 & 176,000 & 1,320 & 2,200 & 1,750 & 3,900 & 66 & 240 & 4,140 \\
\hline Fall (Oct. - Dec.) 2002 & 138 & 182,000 & 294 & 466 & 364 & 830 & 13 & 51 & 881 \\
\hline Total 2001 & 11,300 & $2,850,000$ & 43,500 & 65,900 & 70,000 & 136,000 & 3,370 & 10,700 & 147,000 \\
\hline Total 2002 & 3,570 & $1,370,000$ & 11,700 & 22,400 & 21,800 & 44,200 & 1,040 & 3,890 & 48,100 \\
\hline
\end{tabular}



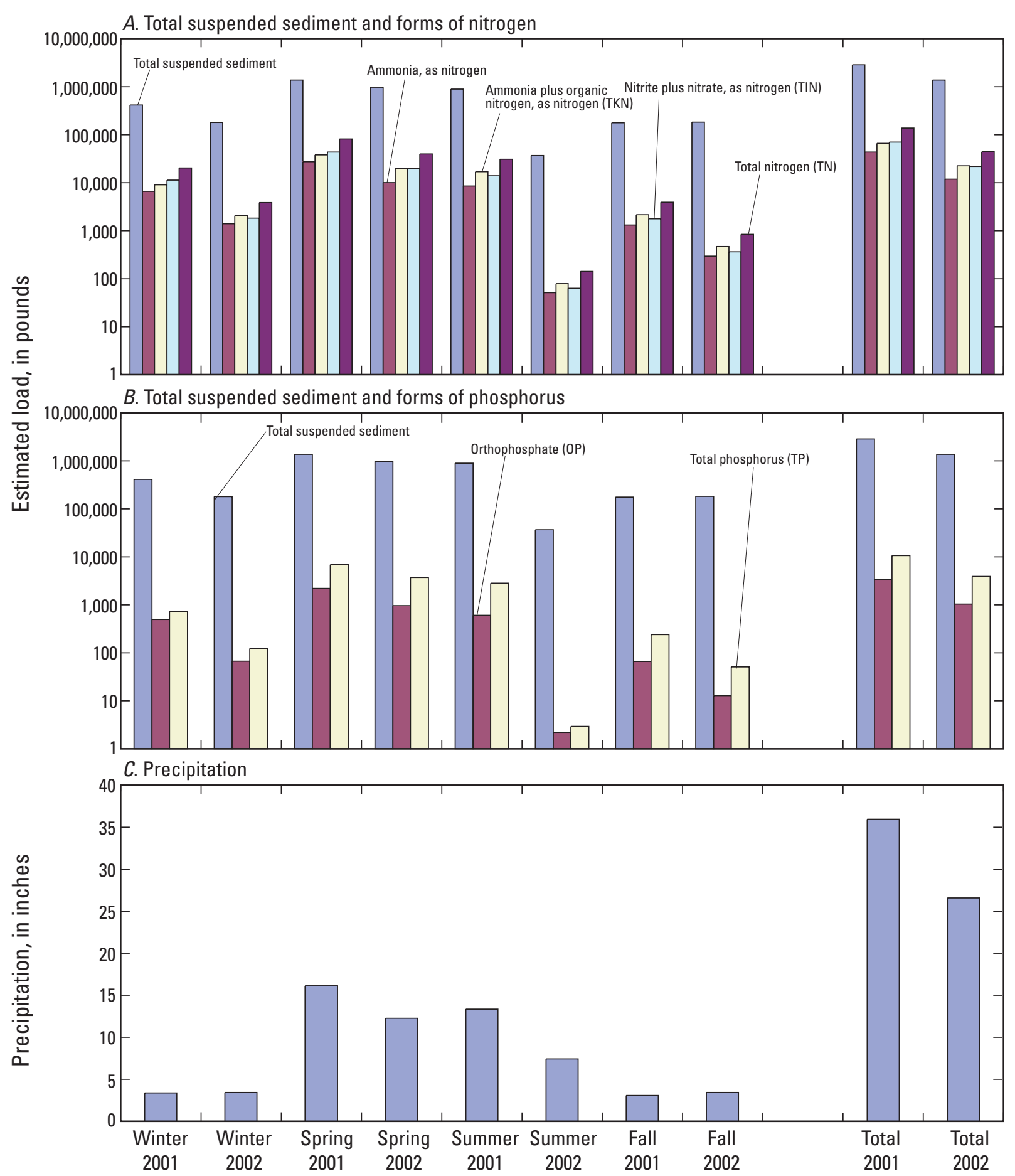

Figure 11. Estimated seasonal loads of suspended sediment and selected nutrients compared to seasonal precipitation for Cedar Creek at Highway 56 (site 1), 2001-02. Location of sampling site shown in figure 1.

$$
\mathrm{OP}=0.0002 \mathrm{Q}+0.022,
$$

where

OP is the concentration of orthophosphate, in milligrams per liter; and

$\mathrm{Q}$ is stream discharge, in cubic feet per second; has a coefficient of determination, $\mathrm{R}^{2}$, of 0.83 , and a t-statistic value of 6.60 for $\mathrm{Q}$ (table 5). Therefore, $\mathrm{Q}$ is statistically significant in the equation, the relation is positive (t-statistic greater than 2) and indicates that nonpoint sources of orthophosphate are the primary source of orthophosphate input to Cedar Creek. 


\section{Surface-Water-Quality Conditions and Relation to Taste-and-Odor Occurrences in the Lake Olathe Watershed, Northeast Kansas, 2000-02}

\section{Estimated Nutrient Yields}

To directly compare nitrogen and phosphorus loading characteristics among different locations, annual loads are divided by the sampling-site drainage areas and are referred to commonly as yields. The resulting values are in units of mass per area as shown in table 10.

There were significant differences in the computed total nitrogen and total phosphorus yields to Lake Olathe between 2001 and 2002 (table 10). Total nitrogen and total phosphorus yields were about three times larger in 2001 than 2002, which probably is related to streamflow. Nutrients and other chemicals from agricultural and residential runoff are transported through Cedar Creek and then to Lake Olathe during or following periods of precipitation. Increased precipitation followed by an increase in streamflow resulted in an increase in chemical transport to Lake Olathe.

Different land-use practices contribute different amounts of nutrients from nonpoint sources. Nutrient yields reported in the literature were summarized in a study by Reckhow and others (1980) for a variety of land-use practices (table 11). The range in values is due to differences in climate, soils, and landmanagement practices in each land-use category. The mean annual yields of total nitrogen and total phosphorus from Cedar Creek, 13.5 and $1.1 \mathrm{lb} / \mathrm{acre}$, respectively, are within the range for agricultural land-use yields (Reckhow and others, 1980) (table 11). Agricultural land use includes cropland and pastureland and is the type of land use commonly observed in the Lake Olathe watershed. The mean annual total phosphorus yield estimated from concentration and streamflow data for Cedar Creek, $1.1 \mathrm{lb} / \mathrm{acre}$, was 20 percent larger than the 45 -year mean total phosphorus yield of $0.91 \mathrm{lb} /$ acre determined through reservoir bottom-sediment analysis (Mau, 2002); however, the values are similar considering the different methods used to compute total phosphorus yields.

Mean annual total phosphorus yields have been computed for many reservoirs in Kansas, ranging from $0.04 \mathrm{lb} / \mathrm{acre}$ at Webster Reservoir in western Kansas to $4.7 \mathrm{lb} / \mathrm{acre}$ at Perry Lake in northeastern Kansas (table 12). Differences in yields can be attributed to differences in land-use practices, precipitation, streamflow, and geomorphic and soil characteristics.

Hillsdale Lake is the closest lake to Lake Olathe and is located about $25 \mathrm{mi}$ south of Lake Olathe. Comparison of mean annual total phosphorus yields from the two lakes, 1.7 and $1.1 \mathrm{lb} / \mathrm{acre}$, respectively, indicated a larger amount of total phosphorus was present in Hillsdale Lake than in Lake Olathe. Further investigation of the two watersheds revealed that the Hillsdale Lake watershed is more populated than the Lake Olathe watershed and that several point-source wastewater-treatment facilities are present in the Hillsdale Lake watershed and could be responsible for the larger total phosphorus loads and yields (Juracek, 1997). However, it should be noted that the period of record for Hillsdale Lake is 1981-96, compared to the Lake Olathe period of record 1956-2000. These differences, along with differences in precipitation, may account for some of the difference between the two watersheds.

\section{Nutrient Limiting Factors}

Factors are said to be limiting if their introduction into a system increases the rate of net primary production (National Research Council, 2000). When applied to nutrients, limiting factors are significant because they can affect growth rates of different algal species that lead to undesirable results in aquatic systems. Concentrations of both nitrogen and phosphorus are detectable in Lake Olathe throughout the year. Because phosphorus is frequently the least abundant nutrient in the environment, it most commonly limits biological activity (Horne and Goldman, 1994, p. 152).

Nutrient ratios commonly are used to determine which major plant nutrients are limiting factors in lakes and reservoirs. These ratios account for the nutritional requirements of phytoplankton relative to the availability in the environment. Only samples from the near surface, where light is available for photosynthesis, were used in the computation of nutrient ratios in this report. The reference mass ratio of 7.2 nitrogen to 1 phosphorus was used $(7.2 \mathrm{~N}: 1 \mathrm{P})$ as a measure of the chemical needs of phytoplankton during photosynthesis (Horne and Goldman, 1994, p. 154). Typically, mass ratios greater than 12 indicate increasing phosphorus limitation, whereas ratios less than 7 indicate an increasing nitrogen limitation. Ratios between 7 and 12 indicate that both nutrients, or neither, may limit algal production (Carney, 2001; Wetzel, 2001).

Two other metrics were used in this report to help determine the relative roles of light and nutrient limitation in Lake Olathe (Scheffer, 1998; Carney, 2001):

$$
\begin{gathered}
\mathrm{NAT}=1 / \mathrm{SD}-0.025(\mathrm{Chl}), \text { and } \\
\mathrm{LA}=\mathrm{Zmix}(\mathrm{NAT}),
\end{gathered}
$$

where

NAT is nonalgal turbidity, in meters ${ }^{-1}$;

SD is Secchi depth, in meters;

Chl is chlorophyll- $a$ concentration, in micrograms per liter;

LA is light availability in the mixed layer, dimensionless; and

Zmix is depth of the mixed layer (depth that 99 percent of incident light will penetrate in the water column, also known as euphotic zone, where sufficient light is available for photosynthesis), in meters.

Nonalgal turbidity (NAT) is a measure of the level of suspended silt and (or) clay in the water and affects water clarity and light penetration. Values of NAT less than $0.4 \mathrm{~m}^{-1}$ tend to indicate very low levels of suspended silt and (or) clay, whereas values of NAT greater than $1.0 \mathrm{~m}^{-1}$ indicate that inorganic particles are very important in creating turbidity. Values of NAT between 0.4 and $1.0 \mathrm{~m}^{-1}$ represent a range where inorganic 
Table 10. Estimated annual and mean annual nutrient loads and yields for Cedar Creek at Highway 56, Olathe, northeast Kansas, $2001-02$.

[Loads rounded to three significant figures. lb, pounds; lb/acre, pounds per acre]

\begin{tabular}{|c|c|c|c|c|c|c|c|c|c|c|c|}
\hline \multirow[b]{2}{*}{ Calendar year } & \multicolumn{11}{|c|}{ Annual loads } \\
\hline & $\begin{array}{c}\text { Ammonia, as } \\
\text { nitrogen (lb) }\end{array}$ & $\begin{array}{c}\text { Ammonia plus } \\
\text { organic } \\
\text { nitrogen } \\
\text { (TKN), as } \\
\text { nitrogen (lb) }\end{array}$ & $\begin{array}{l}\text { Nitrite plus } \\
\text { nitrate (TIN), } \\
\text { as nitrogen } \\
\text { (lb) }\end{array}$ & $\begin{array}{l}\text { Total nitrogen } \\
\text { (TN) } \\
\text { (lb) }\end{array}$ & $\begin{array}{l}\text { Phosphate, } \\
\text { ortho (OP), as } \\
\text { phosphorus } \\
\text { (lb) }\end{array}$ & $\begin{array}{l}\text { Phosphorus, } \\
\text { total (TP), as } \\
\text { phosphorus } \\
\text { (lb) }\end{array}$ & $\begin{array}{c}\text { Total nutrient } \\
\text { load } \\
\text { (lb) }\end{array}$ & $\begin{array}{l}\text { Percentage } \\
\text { TKN of total } \\
\text { nitrogen load, } \\
\text { as nitrogen }\end{array}$ & $\begin{array}{l}\text { Percentage } \\
\text { TIN of total } \\
\text { nitrogen } \\
\text { load, as } \\
\text { nitrogen }\end{array}$ & $\begin{array}{l}\text { Percentage } \\
\text { total nitrogen } \\
\text { (TN) of total } \\
\text { nutrient load }\end{array}$ & $\begin{array}{c}\text { Percentage } \\
\text { total } \\
\text { phosphorus } \\
\text { (TP) of total } \\
\text { nutrient load }\end{array}$ \\
\hline 2001 & 43,500 & 65,900 & 70,000 & 136,000 & 3,370 & 10,700 & 147,000 & 48 & 51 & 93 & 7 \\
\hline 2002 & 11,700 & 22,400 & 21,800 & 44,200 & 1,040 & 3,890 & 48,100 & 51 & 49 & 92 & 8 \\
\hline \multirow[t]{2}{*}{ Mean annual } & 27,600 & 44,200 & 45,900 & 90,100 & 2,200 & 7,300 & 97,600 & 50 & 50 & 92 & 8 \\
\hline & \multicolumn{6}{|c|}{${ }^{1}$ Annual yields } & & & & & \\
\hline Calendar year & $\begin{array}{c}\text { Ammonia, as } \\
\text { nitrogen } \\
\text { (lb/acre) }\end{array}$ & $\begin{array}{c}\text { Ammonia plus } \\
\text { organic } \\
\text { nitrogen } \\
\text { (TKN), as } \\
\text { nitrogen } \\
\text { (lb/acre) }\end{array}$ & $\begin{array}{c}\text { Nitrite plus } \\
\text { nitrate (TIN), } \\
\text { as nitrogen } \\
\text { (lb/acre) }\end{array}$ & $\begin{array}{c}\text { Total nitrogen } \\
\text { (TN) } \\
\text { (lb/acre) }\end{array}$ & $\begin{array}{l}\text { Phosphate, } \\
\text { ortho (OP), as } \\
\text { phosphorus } \\
\text { (lb/acre) }\end{array}$ & $\begin{array}{l}\text { Phosphorus, } \\
\text { total (TP), as } \\
\text { phosphorus } \\
\text { (Ib/acre) }\end{array}$ & & & & & \\
\hline 2001 & 6.3 & 9.5 & 10.1 & 19.7 & 0.5 & 1.5 & & & & & \\
\hline 2002 & 1.7 & 3.2 & 3.2 & 6.4 & .2 & .6 & & & & & \\
\hline Mean annual & 4.0 & 6.4 & 6.6 & 13.0 & .3 & 1.1 & & & & & \\
\hline
\end{tabular}

\footnotetext{
${ }^{1}$ Annual loads divided by a contributing-drainage area of 6,912 acres.
} 


\section{Surface-Water-Quality Conditions and Relation to Taste-and-Odor Occurrences in the Lake Olathe Watershed, Northeast Kansas, 2000-02}

Table 11. Ranges in nutrient yields from nonpoint sources (modified from Reckhow and others, 1980).

[Yields were converted from kilograms per hectare per year in Reckhow and others (1980)]

\begin{tabular}{lcccc}
\hline \multirow{2}{*}{ Dominant land use } & \multicolumn{4}{c}{ Nutrient yields, in pounds per acre per year } \\
\cline { 2 - 5 } & Maximum & Minimum & Mean & Median \\
\hline \multirow{4}{*}{ Forest } & 11.08 & Total nitrogen export & \\
Row crops & 140.89 & 2.44 & 5.06 & 1.35 \\
Nonrow crops & 13.84 & 3.72 & 28.50 & 10.76 \\
Pasture & 54.69 & 1.72 & 9.19 & 9.19 \\
Feedlots & 2.62 & 15.31 & 5,168 \\
Mixed agriculture & 14,125 & 1,205 & 5,505 & 25.31 \\
Urban & 73.46 & 4.99 & 29.21 & 9.74 \\
& 68.15 & 2.62 & 17.65 & .37 \\
Forest & & Total phosphorus export & & 3.96 \\
Row crops & 1.47 & .04 & .42 & 1.35 \\
Nonrow crops & 32.92 & .46 & 7.89 & 1.43 \\
Pasture & 5.13 & .18 & 1.91 & 396 \\
Feedlots & 8.67 & .25 & 2.66 & 1.61 \\
Mixed agriculture & 1,407 & 37.70 & 533 & 1.95 \\
Urban & 5.75 & .14 & 2.00 & 3.38 \\
\hline
\end{tabular}

Table 12. Total estimated sediment deposition, phosphorus concentrations, and phosphorus loads and yields for selected reservoirs in Kansas, 1995-2002.

[lb, pounds; mg/kg, milligrams per kilogram; lb/acre, pounds per acre]

\begin{tabular}{lcccrc}
\hline $\begin{array}{c}\text { Reservoir } \\
\text { (fig. 1) }\end{array}$ & $\begin{array}{c}\text { Period of } \\
\text { record } \\
\text { (years) }\end{array}$ & $\begin{array}{c}\text { Total sediment } \\
\text { deposition } \\
\text { (million lb) }\end{array}$ & $\begin{array}{c}\text { Mean total } \\
\text { phosphorus } \\
\text { concentration } \\
\text { (mg/kg) }\end{array}$ & $\begin{array}{c}\text { Mean annual } \\
\text { total } \\
\text { phosphorus } \\
\text { load } \\
\text { (lb) }\end{array}$ & $\begin{array}{c}\text { Mean annual } \\
\text { total } \\
\text { phosphorus } \\
\text { yield } \\
\text { (lb/acre) }\end{array}$ \\
\hline Cedar Lake $^{1}$ & 62 & 595 & 1,540 & 14,700 & 3.7 \\
Lake Olathe $^{1}$ & 45 & 567 & 774 & 9,720 & 1.1 \\
Webster Reservoir $^{2}$ & 42 & 3,300 & 374 & 29,400 & .04 \\
Cheney Reservoir $^{3}$ & 34 & 15,400 & 480 & 226,000 & .38 \\
Tuttle Creek Lake $^{4}$ & 37 & 194,000 & 481 & $2,520,000$ & .54 \\
Perry Lake $^{5}$ & 39 & 97,200 & 1,100 & $3,350,000$ & 4.7 \\
Hillsdale Lake $^{6}$ & 15 & 4,000 & 509 & 137,000 & 1.7 \\
\hline
\end{tabular}

\footnotetext{
${ }^{1} \mathrm{Mau}$ (2002).

${ }^{2}$ Christensen (1999).

${ }^{3}$ Mau and Christensen (2000).

${ }^{4}$ Juracek and Mau (2002).

${ }^{5}$ Juracek (2003).

${ }^{6}$ Juracek (1997).
} 
turbidity affects water clarity but is not a significant factor until values exceed $1.0 \mathrm{~m}^{-1}$.

LA is a measure of potential algal response to nutrients. The depth of the mixed layer, Zmix, was measured by submerging a light meter to a depth in the water column that represented 1 percent of the incident light value. Values of LA less than 3 indicate there is abundant light and a high algal response to nutrients, whereas values greater than 6 indicate insufficient light penetration and low algal response to nutrients.

A statistical summary of the nutrient ratios and other limiting factors determined for Lake Olathe is provided in table 13. The total nitrogen to total phosphorus ratios were above the threshold value of 12 for each sampling date in 2000-02. The mean and median ratio values for 2001 and 2002 were approximately double the threshold value and indicated that phosphorus may be the nutrient in part responsible for limiting algal growth in Lake Olathe. Varied responses were observed for nonalgal turbidity (NAT) in 2001 and 2002. Although mean values of NAT for 2000-02 were approximately $1.0 \mathrm{~m}^{-1}$, indicating that the primary cause of turbidity in Lake Olathe was silt and clay particles and not organic particles (algal biomass), there were periods when algal biomass was dominant. Values of NAT during February-April 2002 were less than $0.4 \mathrm{~m}^{-1}$, indicating that organic particles, probably related to runoff and suspended sediment, were responsible for the lake turbidity. This may be a result of the reduced inflow (and subsequent less sediment transport) to the lake during January-March 2002 compared with January-March 2001. However, the computed value of NAT in April 2002 was $0.33 \mathrm{~m}^{-1}$ during a period when inflows to Lake Olathe in April-May 2002 were more than double the inflow of April-May 2001. It is unclear why increased inflow to Lake Olathe would result in less turbid water in the lake and low NAT values. The algal response to nutrients on the basis of light availability in Lake Olathe showed that there was abundant light in the mixed-layer zone (Zmix) for algal production, especially during the high algal production months (May to August). During those months, light availability in the mixed layer typically ranged from 1 to 4 (table 13). However, median values in 2001 and 2002 were 8.13 and 3.44, respectively, indicating that light availability necessary for algal growth was substantially better in 2002 than in 2001 (table 13).

In summary, the results of limiting factor analysis indicate that during 2001 and 2002 Lake Olathe was phosphorus limited throughout the year and that turbidity, with some exceptions, was caused by silt and clay particles. In addition, algal growth was limited by insufficient sunlight penetrating the mixed-layer zone during 2001, but light availability was abundant during 2002.

\section{Relation of Chlorophyll and Nutrients to Trophic State of Lake Olathe}

Controlling nutrient loads transported to a lake is an important regulator of algal productivity, or the rate of biomass formation. Within reservoirs, much of the primary productivity

is from phytoplankton (algae suspended in the water column). Because of the typically large drainage-basin area of a reservoir in comparison to a natural lake, the average primary productivity in reservoirs tends to be higher than in natural lake systems (Wetzel, 2001, p. 376). As a result, increases in nutrient loads to reservoirs provide phytoplankton (algae) with an additional food source that can lead to extensive algal blooms.

The proliferation of algal blooms increases the trophic state, which refers to the nutrient status of the water, the biological production occurring in the water, and the morphological characteristics of the reservoir basin itself. Trophic state also is related to the biological responses to factors such as nutrient additions that can be altered by factors such as season, grazing, mixing depth, and so forth (Naumann, 1929).

Concentrations of chlorophyll- $a$ were used in this study to provide a measure of the trophic state of Lake Olathe, a relative classification system that is a measure of the nutrient enrichment in a water body. KDHE has developed guidelines similar to those compiled by USEPA to establish a lake-use impairment identification system in Kansas (table 14) (U.S. Environmental Protection Agency, 1990; Carney, 2001). The trophic states of this system that apply to Lake Olathe are mesotrophic and eutrophic. Mesotrophic reservoirs are those in transition between oligotrophic and eutrophic conditions and generally contain chlorophyll- $a$ concentrations in the range from 3 to $11 \mu \mathrm{g} / \mathrm{L}$. Eutrophic reservoirs typically have large nutrient concentrations, low light penetration, frequent algal blooms, and high densities of phytoplankton and zooplankton, whereas the characteristics of oligotrophic reservoirs are just the opposite of eutrophic reservoirs (Horne and Goldman, 1994, p. 465; Wetzel, 2001, p. 274).

The trophic states categorized by chlorophyll- $a$ concentrations are not always clearly defined. To address this, Carlson (1977) developed a trophic classification system by creating a biomass-based trophic-state index (TSI). The TSI is represented on a scale of 0 to 100 , and every major trophic division of 10 represents a doubling of algal biomass concentration (Sprague, 2002). Reservoirs with TSI values less than 30 are considered oligotrophic, and TSI values between 50 and 70 are considered eutrophic (Wetzel, 2001, p. 284). The following equations to predict Carlson's TSI were developed on the basis of linear regression modeling (Carlson, 1977):

$$
\begin{gathered}
\mathrm{TSI}(\mathrm{Chl})=9.81 \ln (\mathrm{Chl})+30.6, \\
\mathrm{TSI}(\mathrm{TP})=14.42 \ln (\mathrm{TP})+4.15, \text { and } \\
\mathrm{TSI}(\mathrm{SD})=60-14.41 \ln (\mathrm{SD}),
\end{gathered}
$$

where

TSI(Chl) is the trophic-state index that is based on chlorophyll- $a$ concentrations;

TSI(TP) is the trophic-state index that is based on total phosphorus concentration;

TSI(SD) is the trophic-state index that is based on Secchi disk transparency; 
Table 13. Limiting factor analysis for Lake Olathe near dam (site 2), northeast Kansas, 2000-02.

[mg/L, milligrams per liter; $\mu \mathrm{g} / \mathrm{L}$, micrograms per liter; ft, feet; m, meter; --, not applicable]

\begin{tabular}{|c|c|c|c|c|c|c|c|c|c|c|c|}
\hline & $\begin{array}{c}\text { Sampling date } \\
\text { (month/day/ } \\
\text { year) }\end{array}$ & $\begin{array}{l}\text { Total nitrogen } \\
(\mathrm{mg} / \mathrm{L})\end{array}$ & $\begin{array}{l}\text { Phosphorus, } \\
\text { total, as } \\
\text { phosphorus } \\
\text { (mg/L) }\end{array}$ & $\begin{array}{l}\text { Ratio of total } \\
\text { nitrogen to } \\
\text { total } \\
\text { phosphorus }\end{array}$ & $\begin{array}{c}\text { Real-time } \\
\text { continuous } \\
\text { fluorescence } \\
(\mu \mathrm{g} / \mathrm{L})\end{array}$ & $\begin{array}{l}\text { Secchi depth } \\
\text { (ft) }\end{array}$ & $\begin{array}{l}\text { Secchidepth } \\
(\mathrm{m})\end{array}$ & $\begin{array}{l}\text { Depth of } \\
\text { mixed layer } \\
(\text { Zmix) } \\
(\mathrm{ft})\end{array}$ & $\begin{array}{l}\text { Depth of } \\
\text { mixed layer } \\
\text { (Zmix) } \\
\text { (m) }\end{array}$ & $\begin{array}{l}\text { Nonalgal } \\
\text { turbidity } \\
\text { (NAT) }\left(\mathrm{m}^{-1}\right)\end{array}$ & $\begin{array}{l}\text { Light availability } \\
{[\mathrm{LA}=\mathrm{Zmix} \text { (NAT)] }} \\
\text { (dimensionless) }\end{array}$ \\
\hline \multicolumn{12}{|c|}{2000} \\
\hline & $6 / 21 / 2000$ & 0.72 & 0.04 & 18 & 11.3 & 2.40 & 0.74 & 26.2 & 7.99 & 1.07 & 8.64 \\
\hline & $7 / 20 / 2000$ & .76 & .04 & 19 & 10.6 & 3.00 & .91 & 26.2 & 7.99 & .84 & 6.64 \\
\hline & $8 / 22 / 2000$ & .79 & .04 & 20 & -- & 3.30 & 1.01 & 16.4 & 5.00 & -- & -- \\
\hline & $9 / 19 / 2000$ & .81 & .04 & 20 & 8.8 & 3.30 & 1.01 & 19.7 & 6.00 & .77 & 4.68 \\
\hline & $10 / 24 / 2000$ & 1.17 & .07 & 17 & -- & 2.46 & .76 & 37.6 & 11.5 & -- & -- \\
\hline & $12 / 7 / 2000$ & 1.29 & .06 & 22 & 3.8 & 2.30 & .70 & 38.0 & 11.6 & 1.33 & 15.4 \\
\hline Mean & & .92 & .05 & 19 & 8.62 & 2.79 & .86 & 27.4 & 8.35 & 1.00 & 8.84 \\
\hline Median & & .80 & .04 & 19 & 9.70 & 2.73 & .84 & 26.2 & 7.99 & .96 & 7.64 \\
\hline \multicolumn{12}{|c|}{2001} \\
\hline & $3 / 20 / 2001$ & 3.28 & .14 & 23 & 31.1 & 1.64 & .50 & 42.0 & 12.8 & 1.22 & 15.6 \\
\hline & $4 / 18 / 2001$ & 2.77 & .03 & 87 & 4.02 & 3.00 & .91 & 40.0 & 12.2 & .99 & 12.1 \\
\hline & $5 / 17 / 2001$ & 1.80 & .06 & 30 & 16.1 & 4.59 & 1.40 & 15.0 & 4.57 & .31 & 1.42 \\
\hline & $6 / 27 / 2001$ & 1.68 & .04 & 45 & 8.84 & 2.90 & .88 & 15.0 & 4.57 & .91 & 4.16 \\
\hline & $8 / 14 / 2001$ & .84 & .04 & 19 & 5.63 & 3.25 & .99 & 14.0 & 4.27 & .87 & 3.71 \\
\hline & $10 / 23 / 2001$ & 1.08 & .05 & 20 & 16.7 & 2.08 & .63 & 36.0 & 11.0 & 1.16 & 12.7 \\
\hline Mean & & 1.91 & .06 & 37 & 13.7 & 2.91 & .89 & 27.0 & 8.24 & .91 & 8.28 \\
\hline Median & & 1.74 & .05 & 26 & 12.5 & 2.95 & .89 & 25.5 & 7.78 & .95 & 8.13 \\
\hline \multicolumn{12}{|c|}{2002} \\
\hline & $2 / 21 / 2002$ & 1.21 & .03 & 34 & 10.1 & 6.23 & 1.90 & 39.0 & 11.9 & .27 & 3.21 \\
\hline & $4 / 23 / 2002$ & 1.10 & .04 & 27 & 11.6 & 5.33 & 1.62 & 30.0 & 9.14 & .33 & 3.02 \\
\hline & $6 / 4 / 2002$ & 1.32 & .05 & 27 & 22.9 & -- & -- & 10.0 & 3.05 & -- & -- \\
\hline & $6 / 18 / 2002$ & 1.21 & .05 & 22 & 22.5 & 2.88 & .88 & 18.0 & 5.49 & .58 & 3.18 \\
\hline & $7 / 23 / 2002$ & .93 & .04 & 22 & 18.0 & 2.50 & .76 & 14.0 & 4.27 & .86 & 3.67 \\
\hline & $9 / 6 / 2002$ & 1.14 & .06 & 20 & 11.4 & 1.48 & .45 & 12.0 & 3.66 & 1.93 & 7.06 \\
\hline & $10 / 30 / 2002$ & 1.40 & .07 & 20 & 5.70 & 1.35 & .41 & 33.0 & 10.1 & 2.29 & 23.0 \\
\hline Mean & & 1.19 & .05 & 25 & 14.6 & 3.29 & 1.00 & 22.3 & 6.80 & 1.04 & 7.20 \\
\hline Median & & 1.21 & .05 & 22 & 11.6 & 2.69 & .82 & 18.0 & 5.49 & .72 & 3.44 \\
\hline \multicolumn{2}{|c|}{$\begin{array}{l}\text { Lake Olathe mean } \\
(2000-02)\end{array}$} & 1.33 & .05 & 27 & 12.9 & 3.00 & .91 & 25.4 & 7.74 & .98 & 8.01 \\
\hline \multicolumn{2}{|c|}{$\begin{array}{l}\text { Lake Olathe median } \\
(\mathbf{2 0 0 0 - 0 2 )}\end{array}$} & 1.17 & .04 & 22 & 11.3 & 2.89 & .88 & 26.2 & 7.99 & .89 & 5.66 \\
\hline
\end{tabular}


Table 14. Kansas lake-use impairment identification system (from Carney, 1998, p. 11).

$[\mu \mathrm{g} / \mathrm{L}$, micrograms per liter $\}$

\begin{tabular}{|c|c|c|c|}
\hline $\begin{array}{l}\text { Measurement } \\
\text { standard }\end{array}$ & $\begin{array}{c}\text { Concentration } \\
\text { range } \\
(\mu \mathrm{g} / \mathrm{L})\end{array}$ & Trophic state & Description \\
\hline \multirow[t]{6}{*}{ Chlorophyll- $a$} & $6.0-7.0$ & Upper mesotrophic & Aesthetic problems begin to be noticed. \\
\hline & $9.0-10$ & Slightly eutrophic & Definite observable levels of algae. Taste-and-odor problems become noticeable and frequent enough to be a concern. \\
\hline & $12-15$ & Eutrophic & Algae levels tend to be described as moderate. Swimming uses start to be perceived as impaired. \\
\hline & $15-20$ & Upper eutrophic & Algae levels described as high. Contact recreational uses impaired. Water-supply use impaired. \\
\hline & $20-25$ & Very eutrophic & No swimming rules begin to be imposed due to concerns for human health and safety. \\
\hline & $30-80$ & Hypereutrophic & $\begin{array}{l}\text { Severe algae scums typically reported. Recreational, aesthetic, and consumptive uses severely impaired. Aquatic-life } \\
\text { support, biodiversity, and aquatic-habitat quality significantly impaired. }\end{array}$ \\
\hline
\end{tabular}


ln is the natural logarithm function;

Chl is the chlorophyll- $a$ concentration, in micrograms per liter;

TP is the total phosphorus concentration, in micrograms per liter; and

SD is the Secchi disk transparency, in meters.

The relations among the three TSI variables serve as a

check on assumptions about the interactions between various components of the reservoir (Carlson, 1977). The three variables used to compute TSI should be similar in value to each other. Any differences between TSI values may provide information on biological activity and the effects of nutrients in the reservoir. Derivations of the linear regression models used in the computation of TSI suggest that total phosphorus TSI may be a better predictor of the trophic condition of the lake during the summer months than either chlorophyll or Secchi depth TSI (Wetzel, 2001, p. 284). Secchi depth TSI should only be used if phosphorus and chlorophyll data are not available.

TSI computations were similar (indicating eutrophic conditions) between methods that were based on chlorophyll and total phosphorus and indicated that Lake Olathe was eutrophic (table 15). The mean value for TSI that was based on chlorophyll during 2001-02 was 55 compared to a TSI value of 63 that was based on total phosphorus. TSIs that were based on Secchi depth were less than indices that were based on chlorophyll and total phosphorus, reflecting the uncertainty and subjectivity associated with using the Secchi disk.

The equation used to determine Carlson's TSI showed that total phosphorus concentrations of more than $24 \mu \mathrm{g} / \mathrm{L}$ resulted in a TSI of greater than 50 and led to a eutrophic designation.

Mean concentrations of total phosphorus for 2000-02 (table 4) were much larger than $0.02 \mathrm{mg} / \mathrm{L}$ and suggest that Lake Olathe was eutrophic during the years of this study.

The relations among nutrient concentrations in stream inflow, lake nutrient concentrations, and trophic conditions in a lake are complex. However, empirical models have been developed to estimate in-lake nutrient concentrations for a variety of lake types and climatic conditions. One model in particular by Vollenweider (1975) provides a measure of total phosphorus entering a lake and the amount retained in the lake. The model computes the in-lake total phosphorus concentration $(\mathrm{P})$, in milligrams per liter, using the following equation:

$$
\mathrm{P}=\mathrm{L} /\left[\left(\mathrm{v}_{\mathrm{s}}+(\mathrm{z} / \tau)\right],\right.
$$

where

$\mathrm{L}$ is the phosphorus yield, in grams per square meter per year;

$\mathrm{v}_{\mathrm{S}}$ is the apparent settling velocity, in meters per year;

$\mathrm{z}$ is the mean lake depth, in meters; and

$\tau$ is the hydraulic residence time, in years.

The model assumes immediate and complete mixing of the input phosphorus in the lake, that outflow phosphorus concentrations are equal to in-lake phosphorus concentrations, that the phosphorus sedimentation rate is proportional to its
Table 15. Mean trophic-state index (TSI) values for Lake Olathe near dam (site 2), northeast Kansas, 2000-02.

\begin{tabular}{lccc}
\hline Year & $\begin{array}{c}\text { TSI } \\
\text { (chlorophyll) }\end{array}$ & $\begin{array}{c}\text { TSI } \\
\text { (total } \\
\text { phosphorus) }\end{array}$ & $\begin{array}{c}\text { TSI } \\
\text { (Secchi depth) }\end{array}$ \\
\hline 2000 & 52 & 58 & 59 \\
2001 & 56 & 67 & 43 \\
2002 & 56 & 65 & 48 \\
Mean (2000-02) & $\mathbf{5 5}$ & $\mathbf{6 3}$ & $\mathbf{5 0}$ \\
\hline
\end{tabular}

concentration, and that there are negligible seasonal fluctuations in phosphorus loads. The hydraulic residence time is the time required for water in the reservoir to be replaced by either inflowing water or removed by outflowing water (Sprague, 2002). Using the apparent settling velocity of $10 \mathrm{~m} / \mathrm{yr}$ estimated by Vollenweider (1975), a phosphorus yield of $0.12\left(\mathrm{~g} / \mathrm{m}^{2}\right) / \mathrm{yr}$ (converted from 1.1 (lb/acre)/yr in table 10), a mean lake depth of $5.5 \mathrm{~m}(18.2 \mathrm{ft}$ ) (table 1), and a mean hydraulic residence time of 0.45 year (table 16), an in-lake total phosphorus concentration of $0.005 \mathrm{mg} / \mathrm{L}$ was computed from equation 18 . The computed total phosphorus concentration was 10 times less than the observed mean Lake Olathe epilimnion total phosphorus concentration $(0.05 \mathrm{mg} / \mathrm{L}$; table 4$)$ and indicates that a more robust model is necessary to simulate water-quality conditions and trophic response in Lake Olathe. A more robust model would better explain nutrient conditions in Lake Olathe as well as biomass uptake, sedimentation, and water-quality changes in outflow volumes.

\section{Atrazine Loads in Cedar Creek}

Atrazine loads were estimated through regression analysis using ELISA atrazine sample results as the response variable ( $y$ value) and continuous discharge and continuous turbidity as the explanatory variables ( $x$ value). The regression model is presented in table 5. This model was used to estimate hourly atrazine concentrations which were then multiplied by the stream discharge and a conversion factor to determine loads. The hourly loads were summed seasonally and for each year in table 17. Load estimates of atrazine for complete calendar years 2001 and 2002 were evaluated in this study.

Atrazine loads are directly related to streamflow and atrazine concentrations, so that as streamflow or concentration increases, atrazine load increases. In northeast Kansas, it has been shown that large concentrations of atrazine coincide with periods of large streamflow, and usually this occurs immediately after atrazine applications during May through July (Pope and others, 1997). 
Table 16. Hydraulic residence-time analysis for Lake Olathe near dam (site 2), northeast Kansas, 2001-02.

[--, not applicable]

\begin{tabular}{|c|c|c|c|c|c|c|}
\hline Year and month & $\begin{array}{l}\text { Mean monthly } \\
\text { reservoir volume } \\
\text { (acre-feet) }\end{array}$ & $\begin{array}{c}\text { Mean monthly } \\
\text { outflow } \\
\text { (acre-feet per day) }\end{array}$ & $\begin{array}{l}\text { Mean annual } \\
\text { reservoir volume } \\
\text { (acre-feet) }\end{array}$ & $\begin{array}{c}\text { Mean annual } \\
\text { outflow } \\
\text { (acre-feet per day) }\end{array}$ & $\begin{array}{l}\text { Mean annual } \\
\text { hydraulic } \\
\text { residence time } \\
\text { (days) }\end{array}$ & $\begin{array}{l}\text { Mean annual } \\
\text { hydraulic } \\
\text { residence time } \\
\text { (years) }\end{array}$ \\
\hline \multicolumn{7}{|l|}{2001} \\
\hline January & 2,826 & 8.0 & & & & \\
\hline February & 2,829 & 128 & -- & -- & -- & -- \\
\hline March & 2,902 & 29 & -- & -- & -- & -- \\
\hline April & 2,950 & 22 & -- & -- & -- & -- \\
\hline May & 2,986 & 11 & -- & -- & -- & -- \\
\hline June & 2,982 & 77 & -- & -- & -- & -- \\
\hline July & 2,923 & 5.0 & -- & -- & -- & -- \\
\hline August & 2,813 & 1.0 & -- & -- & -- & -- \\
\hline September & 2,964 & 13 & -- & -- & -- & -- \\
\hline October & 2,968 & 10 & -- & -- & -- & -- \\
\hline November & 2,934 & .16 & -- & -- & -- & -- \\
\hline December & 2,933 & .36 & 2,918 & 25 & 117 & 0.32 \\
\hline \multicolumn{7}{|l|}{2002} \\
\hline January & 2,928 & 3.0 & -- & -- & -- & -- \\
\hline February & 2,970 & 12 & -- & -- & -- & -- \\
\hline March & 2,968 & 3.0 & -- & -- & -- & -- \\
\hline April & 2,970 & 39 & -- & -- & -- & -- \\
\hline May & 2,988 & 85 & -- & -- & -- & -- \\
\hline June & 2,948 & 6.0 & -- & -- & -- & -- \\
\hline July & 2,662 & 0 & -- & -- & -- & -- \\
\hline August & 2,273 & 0 & -- & -- & -- & -- \\
\hline September & 1,958 & 0 & -- & -- & -- & -- \\
\hline October & 1,888 & 0 & -- & -- & -- & -- \\
\hline November & 2,005 & 0 & -- & -- & -- & -- \\
\hline December & 1,998 & 0 & 2,546 & 12 & 212 & .58 \\
\hline \multicolumn{6}{|c|}{ Mean hydraulic residence time for $2001-02$} & 0.45 \\
\hline
\end{tabular}

\section{Bacteria Densities, Loads, and Yields in Cedar Creek and Lake Olathe}

Fecal coliform bacteria have long been used as an indicator organism for the sanitary quality of water for drinking or contact recreation. The presence of fecal coliform bacteria in water indicates the possible presence of pathogens, such as entero-, rota-, and reoviruses, found in feces of warmblooded animals. These bacteria and pathogens may cause human diseases ranging from mild diarrhea to respiratory disease, septicemia, meningitis, and polio (Dufour, 1977; Pepper and others, 1996). The fecal coliform bacteria group can include any combination of E. coli and species of the Klebsiella, Enterobacter, and
Citrobacter genera (Gleeson and Gray, 1997). Klebsiella are commonly associated with industrial waste (U.S. Environmental Protection Agency, 1986). Fecal coliform bacteria are found in the feces of all warmblooded animals, but some members of the group also can be found in soil and water (Holt and others, 1993).

In 1986, USEPA recommended that States use E. coli or enterococci bacteria rather than fecal coliform as indicators of fecal contamination for recreational water. E. coli is the only member of the fecal group that is exclusively fecal in origin and, therefore, is definitive evidence of fecal contamination from warmblooded animals. Measuring only E. coli or enterococci rather than the entire fecal coliform group has been shown to give a better indication of possible contamination by organisms 
Table 17. Seasonal and total annual estimates of atrazine loads in Cedar Creek at Highway 56, northeast Kansas, 2001-02.

\begin{tabular}{lc}
\hline & Atrazine (pounds) \\
\hline Winter 2001 & 4 \\
Winter 2002 & 7 \\
Spring 2001 & 11 \\
Spring 2002 & 10 \\
Summer 2001 & 11 \\
Summer 2002 & 1 \\
Fall 2001 & \\
Fall 2002 & 9 \\
Total 2001 & 6 \\
Total 2002 & \\
\hline
\end{tabular}

associated with swimming-related illnesses (Cabelli, 1977; Dufour and Cabelli, 1984). In 2002, USEPA issued revised guidelines with recommended numeric criteria on the basis of risk exposure (U.S. Environmental Protection Agency, 2002).

Bacteria densities are highly variable and are dependent on the source of the bacteria and the hydrologic and environmental conditions. Possible sources of fecal coliform bacteria contamination include municipal wastewater discharges, seepage from domestic septic systems, combined sewer overflows, runoff or seepage from livestock-producing areas, and wildlife populations. Point sources such as wastewater-treatment facilities and combined sewer overflows often discharge fecal coliform bacteria directly into streams. Fecal coliform bacteria in undisturbed feces of warmblooded animals deposited on the land surface can survive for a year or more (Bohn and Buckhouse, 1985). Rainfall on these surfaces transport fecal coliform bacteria into or along the surface of the soil and eventually into surface water and sometimes ground water. Runoff from grazed areas can have 5 to 10 times the amount of fecal coliform bacteria than runoff from ungrazed areas, but both sources of runoff can exceed recommended water-quality criteria (Doran and Linn, 1979).

KDHE lists fecal coliform criteria for Kansas streams designated for either primary contact (full-body) or secondary contact (noncontact) recreational use (Kansas Department of Health and Environment, 2001). During primary contact recreation, the body is immersed in surface water to the extent that some inadvertent ingestion of water is probable. This use includes boating, swimming, skin diving, water skiing, and wind surfing. During secondary contact recreation, ingestion of water is not probable. This use includes wading, fishing, trapping, and hunting (Kansas Department of Health and Environment, 2001). Primary contact criteria for fecal coliform are a geometric mean of $200 \mathrm{col} / 100 \mathrm{~mL}$ from April 1 through
October 31and a single-sample criterion of 2,000 col/100 mL from November 1 through March 31.

In December 2003, KDHE approved $E$. coli to evaluate the sanitary quality of streams. Primary contact criteria for $E$. coli from May to October are 160, 262, and $427 \mathrm{col} / 100 \mathrm{~mL}$ water for class A, B, and C waters, respectively (Kansas Department of Health and Environment, 2003). From November to March primary contact criteria for $E$. coli are 2,358, 2,358, and $3,843 \mathrm{col} / 100 \mathrm{~mL}$ water for class A, B, and C waters, respectively. Class A waters are designated for full-body contact. Class B and C waters have less likelihood of full-body contact or are infrequently used. Sanitary quality is assessed by comparing the geometric mean of five samples collected over 30 days to the criteria (Kansas Department of Health and Environment, 2003). Cedar Creek is designated class C, and Lake Olathe is designated class B.

Section 303(d) of the Federal Clean Water Act of 1972 requires States to identify all water bodies where State waterquality criteria are not being met. In Kansas, 64 percent of the 59,423 stream miles monitored by KDHE in 1998-99 fully supported all uses; about 83 percent fully or partially supported all uses (Kansas Department of Health and Environment, 2000). In 1998, fecal coliform bacteria was listed as an impairment for 611 of the 774 water-quality-limited stream segments (or 79 percent) listed on the 303 (d) list for Kansas (Kansas Department of Health and Environment, 2000).

\section{Comparison of Bacteria Densities}

Concentrations of fecal coliform bacteria in Cedar Creek exceeded 2,000 col/100 mL water for four of the seven samples collected during storm periods in 2000 through 2002 (table 18 and data on file at the USGS office in Lawrence, Kansas). Storm runoff from agricultural and residential areas transports sediment, chemicals, and bacteria to Cedar Creek, increasing the chemical and bacteria concentrations in Cedar Creek and Lake Olathe. Concentrations of fecal coliform bacteria in Cedar Creek ranged from 23 to $65,000 \mathrm{col} / 100 \mathrm{~mL}$ water during the seven storm periods. However, concentrations of fecal coliform bacteria exceeded 2,000 col/100 mL water in samples collected during low-flow conditions in Cedar Creek in July and October 2000. Abundant wildlife and residential septic systems in the area probably account for these elevated concentrations.

Concentrations of fecal coliform bacteria in Lake Olathe were less than criteria for recreational waters in Kansas (table 18). Concentrations of fecal coliform bacteria in water samples collected from Lake Olathe following periods of storm runoff were elevated, but concentrations were still significantly less than the secondary contact criterion of 2,000 col/100 mL water (Kansas Department of Health and Environment, 2001). Geometric-mean density sampling of five samples collected over 30 days was not done as part of this study to determine compliance with the primary recreational use criterion approved by KDHE (2003). However, swimming is not 
Table 18. Statistical summary describing bacteria concentrations in water from Cedar Creek at Highway 56 and Lake Olathe, northeast Kansas, 2000-02.

$[<$, less than; --, not applicable $]$

\begin{tabular}{|c|c|c|c|c|c|c|c|}
\hline \multirow[b]{2}{*}{ Bacteria } & \multirow{2}{*}{$\begin{array}{l}\text { Number of } \\
\text { samples }\end{array}$} & \multicolumn{6}{|c|}{ Density, in colonies per 100 milliliter of water } \\
\hline & & Minimum & Maximum & Mean & Median & $\begin{array}{l}\text { Standard } \\
\text { deviation }\end{array}$ & Water-quality criteria ${ }^{1}$ \\
\hline \multicolumn{8}{|c|}{ Cedar Creek at Highway 56 (site 1, fig. 1) } \\
\hline Fecal coliform bacteria & 17 & 23 & 65,000 & 5,921 & 680 & 15,635 & -- \\
\hline Escherichia coli bacteria & 18 & 23 & 67,000 & 7,199 & 649 & 16,325 & $\begin{array}{c}\text { May-Oct., 427; } \\
\text { Nov.-Mar., 3,843 }\end{array}$ \\
\hline Enterococci bacteria & 10 & 153 & 120,000 & 21,000 & 603 & 39,958 & -- \\
\hline \multicolumn{8}{|c|}{ Lake Olathe near dam (site 2, fig. 1) } \\
\hline \multicolumn{8}{|l|}{ Fecal coliform bacteria } \\
\hline epilimnion & 16 & $<1$ & 510 & 66 & 4 & 161 & $200,2,000^{2}$ \\
\hline hypolimnion & 11 & 1 & 186 & 35 & 6 & 57 & -- \\
\hline \multicolumn{8}{|l|}{ Escherichia coli bacteria } \\
\hline epilimnion & 15 & $<1$ & 677 & 92 & 3 & 207 & -- \\
\hline hypolimnion & 9 & $<1$ & 184 & 39 & 7 & 63 & -- \\
\hline \multicolumn{8}{|l|}{ Enterococci bacteria } \\
\hline epilimnion & 8 & $<1$ & 1,070 & 139 & 4 & 375 & -- \\
\hline hypolimnion & 3 & 1 & 22 & 8 & 2 & 12 & -- \\
\hline \multicolumn{8}{|c|}{ Lake Olathe at upstream end (site 3 , fig. 1) } \\
\hline Fecal coliform bacteria & 6 & 1 & 520 & 134 & 24 & 221 & $200,2,000^{2}$ \\
\hline Escherichia coli bacteria & 5 & 13 & 249 & 87 & 60 & 93 & -- \\
\hline Enterococci bacteria & 1 & 33 & 33 & 33 & 33 & -- & -- \\
\hline
\end{tabular}

${ }^{1}$ Water-quality criteria from Kansas Department of Health and Environment (2003).

${ }^{2}$ Water-quality criteria from Kansas Department of Health and Environment (2001).

allowed in Lake Olathe, so the primary contact recreation criterion that describes full-body contact with water may not apply.

Four of the seven samples collected from Cedar Creek for E. coli during storm runoff exceeded secondary contact criterion (table 18) (Kansas Department of Health and Environment, 2003). Concentrations of $E$. coli during storm runoff ranged from 197 to $67,000 \mathrm{col} / 100 \mathrm{~mL}$ water and from 23 to $13,000 \mathrm{col} / 100 \mathrm{~mL}$ during periods of low flow (data on file at the USGS office in Lawerence, Kansas). However, as stated previously, current (2004) KDHE criteria are based on a geometric mean, not single samples. The concentration of $E$. coli increased during the low-flow sampling periods of July and October 2000 similar to the increased concentration of fecal coliform during the same period. However, the large E. coli concentrations indicate that the source of contamination was fecal material from warmblooded animals, either from animals or humans in the watershed.

Concentrations of enterococci in Cedar Creek were larger than $E$. coli and ranged from 153 to $120,000 \mathrm{col} / 100 \mathrm{~mL}$ water (table 18). Currently, there is no KDHE criterion for enterococci, but USEPA has provided guidance documents as assistance to the States for establishing State criterion (U.S. Environmental Protection Agency, 2002). Water samples were not analyzed for enterococci until 2001; therefore, large fecal coliform and E. coli concentrations identified in July and October 2000 samples cannot be compared to enterococci. Concentrations of enterococci ranged from 677 to $120,000 \mathrm{col} / 100 \mathrm{~mL}$ water during storm runoff and from 153 to $530 \mathrm{col} / 100 \mathrm{~mL}$ water during periods of low flow. In Lake Olathe, the concentration range of enterococci was from less than 1 to $1,067 \mathrm{col} / 100 \mathrm{~mL}$ water (table 18). The elevated concentration of enterococci from the sample collected on April 23, 2002, $(1,070 \mathrm{col} / 100 \mathrm{~mL})$ is similar to the increases observed in E. coli and fecal coliform and probably is in response to a storm that occurred in the watershed on April 21, 2002. Runoff from the storm likely would have transported sediment, chemicals, and bacteria from the watershed into the lake where the bacteria were detected in the lake 2 days after the storm.

\section{Estimated Bacteria Loads and Yields}

Bacteria loads were computed for Cedar Creek during the winter, spring, summer, and fall of 2001 and 2002. Hourly regression-estimated fecal coliform, E. coli, and enterococci 


\section{Surface-Water-Quality Conditions and Relation to Taste-and-Odor Occurrences in the Lake Olathe Watershed, Northeast Kansas, 2000-02}

Table 19. Seasonal and annual estimates of bacteria loads and yields from Cedar Creek at Highway 56, northeast Kansas, 2001-02.

[Estimates are rounded to two significant figures. (col/acre), colonies per acre]

\begin{tabular}{|c|c|c|c|c|c|c|}
\hline & $\begin{array}{l}\text { Fecal coliform } \\
\text { bacteria loads, } \\
\text { in billion colonies }\end{array}$ & $\begin{array}{l}\text { E. coli bacteria } \\
\text { loads, } \\
\text { in billion colonies }\end{array}$ & $\begin{array}{c}\text { Enterococci } \\
\text { bacteria loads, } \\
\text { in billion colonies }\end{array}$ & $\begin{array}{l}\text { Fecal coliform } \\
\text { bacteria yield, } \\
\text { in billion } \\
\text { (col/acre) }\end{array}$ & $\begin{array}{l}\text { E. colibacteria yield, } \\
\text { in billion (col/acre) }\end{array}$ & $\begin{array}{c}\text { Enterococci } \\
\text { bacteria yield, } \\
\text { in billion } \\
\text { (col/acre) }\end{array}$ \\
\hline Winter 2001 & $1,100,000$ & 140,000 & $4,400,000$ & 160 & 21 & 660 \\
\hline Winter 2002 & 42,000 & 9,000 & 140,000 & 6 & 1 & 21 \\
\hline Spring 2001 & $6,400,000$ & $2,900,000$ & $29,000,000$ & 960 & 430 & 4,400 \\
\hline Spring 2002 & $2,400,000$ & $1,400,000$ & $10,000,000$ & 350 & 210 & 1,600 \\
\hline Summer 2001 & $2,400,000$ & 840,000 & $11,000,000$ & 370 & 130 & 1,600 \\
\hline Summer 2002 & 940 & 560 & 3,600 & 0 & 0 & 1 \\
\hline Fall 2001 & 110,000 & 38,000 & 450,000 & 17 & 6 & 68 \\
\hline Fall 2002 & 12,000 & 5,300 & 41,000 & 2 & 1 & 6 \\
\hline Total 2001 & $10,000,000$ & $3,900,000$ & $45,000,000$ & 1,500 & 590 & 6,700 \\
\hline Total 2002 & $2,500,000$ & $1,400,000$ & $10,000,000$ & 360 & 210 & 1,600 \\
\hline
\end{tabular}

densities were multiplied by streamflow, conversion factors, and the bias-correction factors to estimate seasonal and total annual loads and yields in Cedar Creek with continuous turbidity measurements (tables 5 and 19). Bacteria yields were determined by dividing bacteria loads by the contributing-drainage area for Lake Olathe in 2001 and 2002.

Continuous turbidity measurements were used to estimate bacteria loads because of the strong correlation between turbidity and bacteria. However, the computation of bacteria loads and yields on the basis of turbidity was limited by the maximum turbidity values that could be measured by the sensor. The sensors used in this study were capable of measuring maximum turbidity between 0 and 1,000 NTU, depending on the sensor. During periods when the actual turbidity was greater than the measured turbidity, the sensor was capable of measuring only the maximum reading. When this occurred, loads were computed on the basis of the maximum sensor reading. There were only 13 affected hourly turbidity sensor readings in 2001 , and 8 affected readings in 2002 of a possible 8,760 values per year. Although the regression-estimated loads may be conservative by an unknown amount, most likely the loads were minimally affected by maximum turbidity readings. Previous studies indicate that bacteria loads during individual days can underestimate the actual load by as much as 20 times (Rasmussen and Ziegler, 2003, p. 70).

An additional limitation in the computation of loads and yields is bacterial loss rate. Bacterial loss rate is the bacteria mortality rate, loss due to solar radiation, and loss due to bacterial settling (Rasmussen and Ziegler, 2003, p. 70). The loss rate is dependent upon environmental, water-quality, and streamflow conditions, and is unknown for this study.
Regression-estimated total annual bacteria loads were about three to four times larger in 2001 than in 2002 in Cedar Creek (table 19). The differences probably are due to the different hydrologic conditions for the 2 years. Precipitation was greater in 2001 than in 2002, likely contributing more overland runoff, and therefore, more nonpoint-source bacteria to Cedar Creek. Seasonal differences indicated that the largest bacteria loads occurred in the spring (April through June) of each year and represented between 65 and 93 percent, respectively, of the total bacteria load delivered to Lake Olathe in 2001 and 2002 (table 19). The effect of a dry year was evident in 2002, when 93 percent of the total bacteria load was delivered to Lake Olathe during the spring compared to 65 percent in 2001.

\section{Phytoplankton Characteristics of Lake Olathe}

Phytoplankton are small, free-floating algae that generally are not visible to the naked eye, but when concentrated they are responsible for the characteristic green color and reduced transparency of water in many lakes (Horne and Goldman, 1994, p. 226). Phytoplankton usually grow in pulses or blooms in temperate climates. The first blooms occur in the spring, notably diatoms, in response to sunlight, and end in the fall as sunlight decreases. In warmer temperate areas, algal growth can be continuous when sufficient nutrients are available. In temperate lakes and reservoirs, algal blooms later in the summer often consist of cyanobacteria or, less often, green algae. In addition, algae have evolved various methods to overcome limitations of nutrients and grazing by larger organisms. These methods include chemically binding nutrients, notably phosphorus, 
within algal cells to be released and used when needed, production of enzymes to enhance rates of nutrient uptake during periods of small nutrient concentrations, and changes in cell density that allow algae to move vertically into more favorable light or nutrient areas of the water column (Horne and Goldman, 1994, p. 226). Some phytoplankton taxa also can cause taste-andodor problems in drinking-water supplies and in some instances can cause toxicity (Mallevialle and Suffet, 1987; Horne and Goldman, 1994, p. 256).

\section{Community Composition}

Major genera and species of phytoplankton, as well as chlorophyll $a, b$, and total biovolume and biomass, were identified in samples from Cedar Creek and Lake Olathe (table 20, tables 27-28, in "Supplemental Information" section of this report). There were sampling periods when as many as seven phytoplankton divisions were identified along with their corresponding species, but typically three divisions represented 90 percent or more of all the genera-Bacillariophyta (diatoms), Chlorophyta (green algae), and cyanobacteria (bluegreen algae).

A primary characteristic of diatoms are silicified cell walls. The cell walls (frustules) of diatoms consist of two lidlike valves, one of which fits inside the other. The cell wall structures are complex and are used as taxonomic characteristics (Wetzel, 2001, p. 336). In temperate climates, diatoms commonly are the predominant algal species during spring. Increasing sunlight, temperature, water circulation, and turbulence help suspend and maintain the diatom colonies in the optimal light intensities, thus enhancing their growth. Blooms of several species of diatoms have been associated with taste-andodor problems in drinking-water supplies (Wetzel, 2001).

Chlorophyta, or green algae, are a very large and diverse group of algae that are distributed primarily in freshwater (Wetzel, 2001). They contain both chlorophyll $a$ and $b$ and may have a tail (flagellum) that provides mobility for one phase of their life cycle (Horne and Goldman, 1994). Although a food source for a large variety of organisms, the presence of Chlorophyta blooms in lakes may be indicative of eutrophic conditions and also may impair fisheries.

Cyanobacteria (blue-green algae) have been some of the most intensely studied of all planktonic groups (Wetzel, 2001). They have characteristics of both bacteria and algae; like other bacteria they lack a nuclear membrane, but they possess chlorophyll- $a$, which is common to algae and higher plants. In particular, some species of cyanobacteria have the unique ability to fix elemental nitrogen $\left(\mathrm{N}_{2}\right.$, atmospheric nitrogen), which provides a metabolic advantage over other algae during periods of low dissolved oxygen, low light, and lack of other resources. An additional advantage found in cyanobacteria but not other algae is that some species contain gas vacuoles that regulate buoyancy, allowing the cyanobacteria to maneuver in the water column as they seek the ideal sunlight and nutrient conditions optimal for growth. Cyanobacteria can cause unsightly algal blooms on eutrophic lakes that shade out other algae and higher organisms that benefit the lake fishery. In addition, some cyanobacteria species are capable of manufacturing toxins and unpleasant tasting compounds, such as geosmin and MIB.

Two additional divisions, Cryptophyta and Euglenophyta, also were identified in Lake Olathe. Cryptophyta are flagellated and typically are present in small numbers for most of the year but increase intermittently. Increases in their abundance often follow the demise of previous dominant algal blooms (Wetzel, 2001). Euglenophyta can possess as many as three flagella and under the right conditions can grow rapidly. Their development is closely related to the abundance of ammonia and dissolved organic matter, and they are found most often in shallow water rich in organic matter, such as organically polluted lakes (Wetzel, 2001, p. 338).

\section{Species Diversity}

Species diversity is a property unique to the community level of biological organization and is an expression of community structure (Brower and others, 1998, p. 177). Species diversity can affect the survival of other organisms that consume phytoplankton and the efficiency of transfer of primary production to larger organisms. A community that has many abundant species in approximately equal proportions is said to have high species diversity and indicates the presence of a highly complex biological community. There are many measures of species diversity, but two of the most common measures, the Simpson's Diversity Index and the Shannon-Wiener Diversity Index, are discussed in this report. Diversity indices provide information about rarity and commonness of species in a community.

Simpson's Diversity Index (Ds) evaluates the number of species, the total number of individuals in each species $(\mathrm{N})$, and the proportion of the total number of individuals that occurs in each species (Simpson, 1949). The equation developed by Simpson shows that a community with high diversity will have species with low dominance, and a community with low diversity will have species with high dominance (Brower and others, 1998, p. 179):

$$
\mathrm{D}_{\mathrm{s}}=1-\left(\Sigma \mathrm{n}_{\mathrm{i}}\left(\mathrm{n}_{\mathrm{i}}-1\right)\right) / \mathrm{N}(\mathrm{N}-1),
$$

where

$\mathrm{D}_{\mathrm{s}}$ is Simpson's Diversity Index, dimensionless;

$\mathrm{n}_{\mathrm{i}}$ is number of species; and

$\mathrm{N}$ is the total number of individuals in each species.

The index ranges from 0 (low diversity) to almost 1 (high diversity), and a diverse phytoplankton community should have a high Simpson's Diversity Index. In the Lake Olathe study, phytoplankton community structure was considered to be diverse if $\mathrm{D}_{\mathrm{s}}$ was greater than or equal to 0.6.

The Shannon-Wiener Diversity Index ( $\left.\mathrm{H}^{\prime}\right)$ is used as a measure of the number of taxa and the evenness of the taxa 
Table 20. Statistical summary describing phytoplankton-related concentrations in water from Cedar Creek at Highway 56 and Lake Olathe, northeast Kansas,

[HPLC, high-performance liquid chromatography; $\mu \mathrm{g} / \mathrm{L}$, micrograms per liter; mg/L, milligrams per liter; col/mL, colonies per milliliter of water; ng/L, nanograms per liter; <, less than; ,-- not applicable]

\begin{tabular}{ccccc}
\hline $\begin{array}{c}\text { Phytoplankton-related concentrations } \\
\text { (unit of measurement) }\end{array}$ & $\begin{array}{c}\text { Number of } \\
\text { samples }\end{array}$ & Minimum & Maximum & Mean
\end{tabular}

Chlorophyll- $a$, HPLC $(\mu \mathrm{g} / \mathrm{L})$

Chlorophyll- $b$, HPLC $(\mu \mathrm{g} / \mathrm{L})$

Cedar Creek at Highway 56 (site 1, fig. 1)

Chlorophyll- $a$, fluorescence $(\mu \mathrm{g} / \mathrm{L})$

Phytoplankton biomass, ash weight $(\mathrm{mg} / \mathrm{L})$

Phytoplankton biomass, dry weight (mg/L)

Ash-free dry mass $(\mathrm{mg} / \mathrm{L})$

Microcystin $(\mu \mathrm{g} / \mathrm{L})$

Actinomycetes $(\mathrm{col} / \mathrm{mL})$

Geosmin (ng/L)

2-methylisoborneol (MIB) (ng/L)

Chlorophyll- $a$, HPLC $(\mu \mathrm{g} / \mathrm{L})$

$$
\text { epilimnion }
$$

hypolimnion

Chlorophyll- $b$, HPLC $(\mu \mathrm{g} / \mathrm{L})$

epilimnion

hypolimnion

Chlorophyll- $a$, fluorescence $(\mu \mathrm{g} / \mathrm{L})$

$$
\text { epilimnion }
$$

hypolimnion

14

10

10

10

--

1

7

7

Phytoplankton biomass, ash weight (mg/L) epilimnion hypolimnion

Phytoplankton biomass, dry weight (mg/L)

$$
\text { epilimnion }
$$

hypolimnion
15

5

15

20

9

14

5

14

$\begin{array}{rr}1 & 29 \\ 0 & 8 \\ 2 & 58 \\ 526 & 5,500 \\ 536 & 5,600\end{array}$

14
3
19
2,890
2,900

$\begin{array}{rr}12 & 12 \\ 1 & 3 \\ 15 & 15 \\ 2,700 & 1,600 \\ 2,800 & 1,700\end{array}$

$\begin{array}{rr}10 & 128 \\ -- & -- \\ 2,300 & 2,300 \\ <5 & 20 \\ <5 & 11\end{array}$

Lake Olathe near dam (site 2, fig. 1)

.6

.1

.1

.1

3.8

4.0

660

670

670

690

\section{8}

15.6

8.7

1.3

31.1

11.6

5,200

2,700

5,300

2,700

54
--
2,300
6.1
$<5$

48

41

--

6.4

3.4

$<5$

9.4

6.7

2.2

.5

7.2

2.4

7.0

2,300

2,200

1,100

870

2,400

2,300

2,600

1,100

880 
Table 20. Statistical summary describing phytoplankton-related concentrations in water from Cedar Creek at Highway 56 and Lake Olathe, northeast Kansas, 2000-02. - Continued

[HPLC, high-performance liquid chromatography; $\mu \mathrm{g} / \mathrm{L}$, micrograms per liter; $\mathrm{mg} / \mathrm{L}$, milligrams per liter; col/mL, colonies per milliliter of water; ng/L, nanograms per liter; <, less than; ,-- not applicable]

\begin{tabular}{|c|c|c|c|c|c|c|}
\hline \multirow{2}{*}{$\begin{array}{l}\text { Phytoplankton-related concentrations } \\
\text { (unit of measurement) }\end{array}$} & \multirow{2}{*}{$\begin{array}{l}\text { Number of } \\
\text { samples }\end{array}$} & \multicolumn{5}{|c|}{ Concentration } \\
\hline & & Minimum & Maximum & Mean & Median & Standard deviation \\
\hline \multicolumn{7}{|c|}{ Lake Olathe near dam (site 2, fig. 1)-Continued } \\
\hline \multicolumn{7}{|l|}{ Ash-free dray mass (mg/L) } \\
\hline epilimnion & 14 & 3 & 92 & 35 & 35 & 23 \\
\hline hypolimnion & 5 & 15 & 54 & 36 & 30 & 16 \\
\hline \multicolumn{7}{|l|}{ Microcystin (mg/L) } \\
\hline epilimnion & 3 & $<.1$ & .28 & .19 & .26 & .12 \\
\hline hypolimnion & 2 & .1 & .17 & .14 & .14 & .05 \\
\hline \multicolumn{7}{|l|}{ Actinomycetes (col/mL) } \\
\hline epilimnion & 6 & 4 & 64 & 18 & 10 & 23 \\
\hline hypolimnion & 2 & 43 & 600 & 321 & 321 & 394 \\
\hline \multicolumn{7}{|l|}{ Geosmin (ng/L) } \\
\hline epilimnion & 13 & $<5$ & 12 & $<5$ & $<5$ & $<5$ \\
\hline hypolimnion & 6 & $<5$ & 65 & 17.5 & 6.1 & 24.5 \\
\hline \multicolumn{7}{|l|}{ 2-methylisoborneol (MIB) (ng/L) } \\
\hline epilimnion & 13 & $<5$ & $<5$ & $<5$ & $<5$ & -- \\
\hline hypolimnion & 6 & $<5$ & 6 & $<5$ & $<5$ & -- \\
\hline \multicolumn{7}{|c|}{ Lake Olathe at upstream end (site 3 , fig. 1) } \\
\hline Chlorophyll- $a$, HPLC ( $\mu \mathrm{g} / \mathrm{L})$ & 5 & 1.7 & 25.2 & 11.7 & 9.0 & 10.6 \\
\hline Chlorophyll- $b$, HPLC $(\mu \mathrm{g} / \mathrm{L})$ & 5 & $<.1$ & 2.9 & 1.6 & 1.6 & 1.3 \\
\hline Chlorophyll- $a$, fluorescence $(\mu \mathrm{g} / \mathrm{L})$ & 5 & 7.8 & 29.5 & 16.0 & 12.4 & 9.0 \\
\hline Phytoplankton biomass, ash weight (mg/L) & 5 & 670 & 20,000 & 5,500 & 2,600 & 8,400 \\
\hline Phytoplankton biomass, dry weight (mg/L) & 5 & 680 & 21,000 & 5,600 & 2,700 & 8,400 \\
\hline Ash-free dry mass (mg/L) & 5 & 16 & 58 & 35 & 32 & 18 \\
\hline Microcystin $(\mu \mathrm{g} / \mathrm{L})$ & 1 & .32 & .32 & .32 & .32 & -- \\
\hline Actinomycetes (col/mL) & 1 & 21 & 21 & 21 & 21 & -- \\
\hline Geosmin (ng/L) & 5 & $<5$ & 8.1 & $<5$ & $<5$ & $<5$ \\
\hline 2-methylisoborneol (MIB) (ng/L) & 5 & $<5$ & $<5$ & $<5$ & $<5$ & -- \\
\hline
\end{tabular}




\section{Surface-Water-Quality Conditions and Relation to Taste-and-Odor Occurrences in the Lake Olathe Watershed, Northeast Kansas, 2000-02}

abundance (Brower and others, 1998, p. 180). Values can range from 0 , where all individuals are the same taxon, to a maximum value dependent upon the number of species present. Maximum values of the Shannon-Wiener Diversity Index, calculated on the logarithmic base- 10 form of the following equation for samples containing 10, 25, and 50 species, would be 1.0, 1.4, and 1.7, respectively. A diverse phytoplankton community should have a high Shannon-Wiener Diversity Index, and values for the Lake Olathe study of 0.6 or greater were considered diverse. The Shannon-Wiener Diversity Index equation is:

$$
H^{\prime}=-\Sigma p_{i} \log p_{i},
$$

where

$\mathrm{H}^{\prime}$ is Shannon-Wiener Diversity Index, dimensionless; and

$p_{i}$ is $n_{i} / N$ (defined in equation 19).

The Simpson's Diversity Index $\left(\mathrm{D}_{\mathrm{s}}\right)$ and the ShannonWiener Diversity Index (H') were evaluated for phytoplankton communities in both Cedar Creek and Lake Olathe (table 21). Values of $\mathrm{D}_{\mathrm{s}}$ in Cedar Creek during 2000 to 2002 ranged from 0.675 to 0.890 , indicating good species diversity. Bacillariophyta were the most diverse division in Cedar Creek during the study period and the most dominant in almost every sample collected, although there were periods during 2000 when many species of Euglenophyta were present (table 27, in "Supplemental Information" section of this report).

Bacillariophyta species were diverse in spring and summer 2002, either because of environmental conditions or the presence of excess nutrients and silica. Euglenophyta species were particularly diverse in 2000 and 2001, indicative of organically enriched conditions in Lake Olathe during that time. The mean and median $\mathrm{D}_{\mathrm{s}}$ values for 2000-02 were greater than 0.6 at Cedar Creek and Lake Olathe, suggesting phytoplankton were absent of any extreme values (table 21). The mean and median $\mathrm{D}_{\mathrm{S}}$ values for Cedar Creek were similar (0.807 and 0.850, respectively), indicating a relatively diverse phytoplankton community structure within Cedar Creek during the study period. The mean and median $\mathrm{D}_{\mathrm{s}}$ values for Lake Olathe also were similar during the study period $(0.706$ and 0.772 , respectively). However, diversity was greater in Cedar Creek than in Lake Olathe.

Values of the log-10 based Shannon-Wiener Diversity Index $\left(\mathrm{H}^{\prime}\right)$ were similar to values of $\mathrm{D}_{\mathrm{S}}$ and ranged from 0.452 to 1.205. Values of H' at Cedar Creek for the period 2000 through 2002 showed good species diversity, and values generally were larger than H' values in Lake Olathe (table 21). Species diversity in Lake Olathe during the spring and summer 2002 was low relative to 2000 and 2001, as indicated by H' values less than 0.6 (table 21). During June through September 2002, one species of either Bacillariophyta or Chlorophyta represented more than 50 percent of the total biovolume in the lake (table 27, in "Supplemental Information" section of this report). The dominance by a few species in Lake Olathe during these months was reflected in the low H' values (less than 0.6) that described phytoplankton species diversity and community
Table 21. Simpson's and Shannon-Wiener Diversity Index values for Cedar Creek at Highway 56 and epilimnion of Lake Olathe near dam (site 2), northeast Kansas, 2000-02.

\begin{tabular}{|c|c|c|c|}
\hline Location & $\begin{array}{c}\text { Date } \\
\text { (month/day/ } \\
\text { year) }\end{array}$ & $\begin{array}{c}\text { Simpson's } \\
\text { Diversity Index } \\
\text { (Ds) } \\
\text { (dimensionless) }\end{array}$ & $\begin{array}{c}\text { Shannon-Wiener } \\
\text { Diversity Index } \\
\left(\mathrm{H}^{\prime}\right)\left(\log _{10} \text { based, }\right. \\
\text { dimensionless) }\end{array}$ \\
\hline \multirow[t]{16}{*}{ Cedar Creek } & $6 / 19 / 2000$ & 0.890 & 1.145 \\
\hline & $6 / 20 / 2000$ & .772 & .785 \\
\hline & $7 / 19 / 2000$ & .888 & 1.205 \\
\hline & $10 / 24 / 2000$ & .675 & .569 \\
\hline & $3 / 21 / 2001$ & .763 & .764 \\
\hline & $4 / 19 / 2001$ & .679 & .738 \\
\hline & $5 / 16 / 2001$ & .847 & .940 \\
\hline & $6 / 3 / 2001$ & .854 & .945 \\
\hline & $6 / 26 / 2001$ & .860 & .973 \\
\hline & $3 / 16 / 2002$ & .728 & .787 \\
\hline & $4 / 21 / 2002$ & .862 & 1.051 \\
\hline & $5 / 12 / 2002$ & .866 & 1.010 \\
\hline & Mean & .807 & .909 \\
\hline & Median & .850 & .942 \\
\hline & Maximum & .890 & 1.205 \\
\hline & Minimum & .675 & .569 \\
\hline \multirow[t]{21}{*}{ Lake Olathe } & $6 / 20 / 2000$ & .772 & .785 \\
\hline & $6 / 21 / 2000$ & .792 & .898 \\
\hline & $10 / 24 / 2000$ & .772 & .734 \\
\hline & $12 / 7 / 2000$ & .647 & .568 \\
\hline & $3 / 20 / 2001$ & .542 & .475 \\
\hline & $4 / 18 / 2001$ & .705 & .611 \\
\hline & $5 / 17 / 2001$ & .803 & .827 \\
\hline & $6 / 27 / 2001$ & .773 & .790 \\
\hline & $8 / 14 / 2001$ & .775 & .835 \\
\hline & $10 / 23 / 2001$ & .828 & .979 \\
\hline & $2 / 21 / 2002$ & .669 & .668 \\
\hline & $4 / 23 / 2002$ & .886 & 1.064 \\
\hline & $6 / 4 / 2002$ & .665 & .725 \\
\hline & $6 / 18 / 2002$ & .509 & .452 \\
\hline & $7 / 23 / 2002$ & .483 & .467 \\
\hline & $9 / 6 / 2002$ & .573 & .510 \\
\hline & $10 / 30 / 2002$ & .806 & .902 \\
\hline & Mean & .706 & .723 \\
\hline & Median & .772 & .734 \\
\hline & Maximum & .886 & 1.064 \\
\hline & Minimum & .483 & .452 \\
\hline
\end{tabular}


structure in Lake Olathe. The low H' values may be a reflection of the dry period in the Lake Olathe watershed from June through September 2002 when lake levels were several feet below the spillway elevation. Long periods of standing water may have contributed to low species diversity and benefited only select species.

\section{Relation to Environmental Factors}

Total biovolume did not vary much among the samples, with the exception of one June 2000 sample, and was within the same order of magnitude in most samples (fig. 12). This was somewhat surprising because algal abundance (biovolume or chlorophyll-a) varies seasonally in most lakes (Horne and Goldman, 1994, p. 226). Common taxa in the lake included Cyclotella spp., Chlamydomonas spp, Trachelomonas spp., and Cryptomonas spp. (table 28 in "Supplemental Information" section of this report). All four taxa occurred in 20 or more of the 31 samples. The Cyclotella species are diatoms found commonly in eutrophic rivers and lakes (Lowe, 1974). The last three taxa were unicellular, motile algal flagellates from the divisions Chlorophyta (green algae), Euglenophyta, and Cryptophyta, respectively. The algal flagellates occur over a broad range of water-quality conditions; however, these taxa are considered to be in the mesotrophic-to-eutrophic range (Prescott, 1962). Trachelomonas species often indicate dissolved iron in the water from either natural or human-related sources.

Phytoplankton taxa were identified in samples from both Cedar Creek and Lake Olathe. There were instances when as many as seven algal divisions were identified, but typically
Bacillariophyta, Chlorophyta, and cyanobacteria represented 90 percent or more of all taxa (fig. 13). Some of the taxa identified in Lake Olathe, such as Asterionella formosa (Bacillariophyta), Oscillatoria spp. (cyanobacteria), and Lyngbya limnetica (cyanobacteria) are known producers of taste-and-odor compounds that may be responsible for problems associated with the Lake Olathe drinking-water supply.

The results of correspondence analysis indicated that samples collected in June 2000 were very different from those collected in June 2001 and 2002. The samples collected in 2000 were dominated by Anabaena and Pseudoanabaena, both of which are eutrophic, nitrogen-fixing cyanobacteria. Nitrogen fixers generally are found in water with low dissolved nitrogen or low dissolved N:P ratios, probably because these taxa can fix atmospheric nitrogen and thus compete well where nitrogen is in limited supply. In contrast, June samples collected during 2001-02 were dominated by centric diatoms and the algal flagellates previously discussed (notably Chlamydomonas) (table 28 in "Supplemental Information" section of this report). The diatom species of Cyclotella and Melosira, notably M. granulata and $M$. islandica, are found commonly in turbid (sediment-laden) rivers (Lowe, 1974). A large algal bloom during the spring of 2000 may have depleted available dissolved nitrogen (and possibly silica). By June 2000 the successful algal competitors were those that could manufacture their own nitrogen (nitrogen fixers) and required little silica. There were taste-and-odor producing species in both groups; taxa identified in 2000 contained species associated with "grassy" or "musty" odors, such as Melosira, Synedra, and Anabaena, whereas the taxa identified in 2001 and 2002 contained species of diatoms

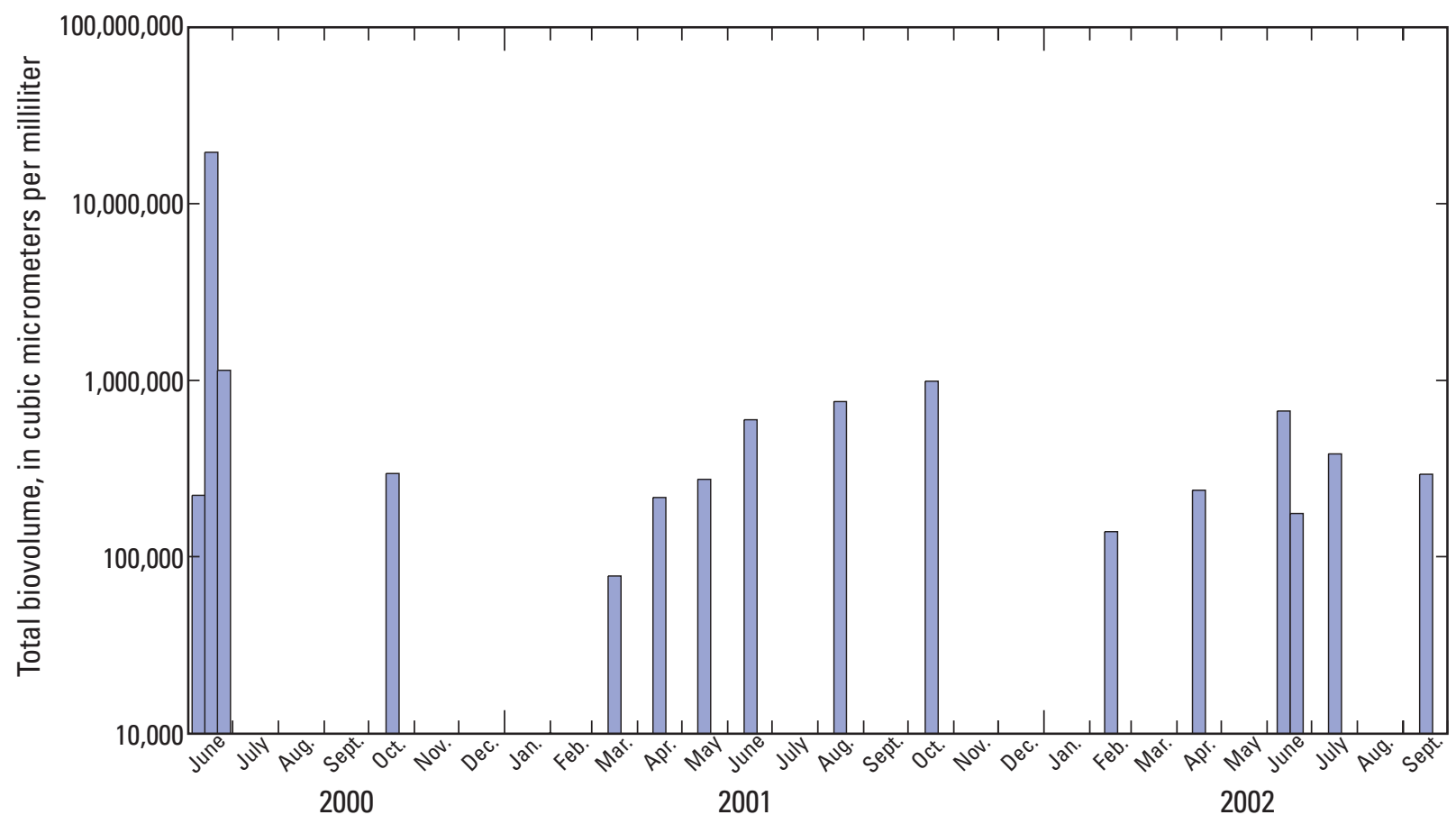

Figure 12. Total biovolume in epilimnion of Lake Olathe near dam (site 2), 2000-02. 


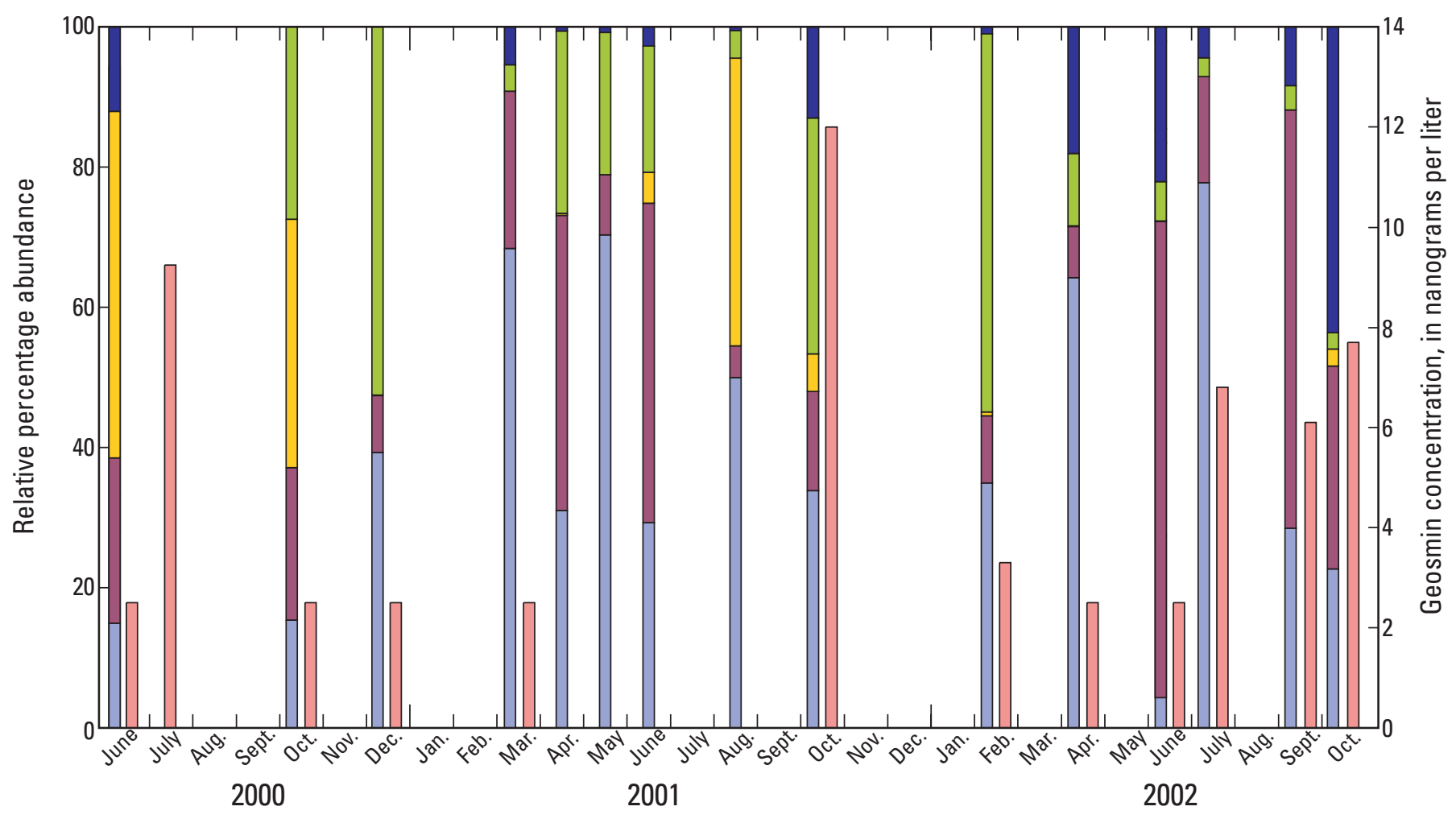

\section{EXPLANATION}

\begin{tabular}{|l}
$\square$ Bacillariophyta \\
$\begin{array}{l}\text { Chlorophyta } \\
\square\end{array}$ Cryptophyta \\
\begin{tabular}{|l} 
Cyanobacteria \\
$\square$
\end{tabular} Euglenophyta \\
\hline
\end{tabular}

Figure 13. Relative percentage abundance of phytoplankton divisions and geosmin concentrations in Lake Olathe near dam (site 2), 2000-02.

that can cause "fishy" odors, such as Asterionella, Cyclotella, and Chlamydomonas (Palmer, 1977).

Correspondence analysis of the August 2001 samples also identified a co-dominance of diatoms (Cyclotella and Melosira spp.) and nitrogen fixers (Anabaena spp.). It may be that dissolved nitrogen was limiting during this period, but silica was not. Planktonic Melosira taxa generally are found in turbid lakes and rivers (Weber, 1971; Lowe, 1974); thus, there may have been more wash-in of sediment during the months prior to the time these samples were collected. Besides the occurrence of these diatoms, this group differed from the previous (June 2000) group by the reduced numbers of Pseudoanabaena.

Phytoplankton samples collected during March-May 2001 were dominated by diatoms and algal flagellates, starting with Cyclotella spp. in March and then dominated by Melosira spp. later in the spring. Spring dominance by diatoms and (or) algal flagellates (particularly Chlorophyta and Cryptomonas algae) often is found in temperate lakes and reservoirs (Wetzel, 2001, p. 361). The abundance of the diatom Asterionella formosa, notably during May 2001 (7-17 percent), also could be associated with taste-and-odor complaints (Palmer, 1977).

Phytoplankton communities in October (2000-01) were dominated by the flagellates, notably Trachelomonas spp.,
Chlamydomonas spp., and Cryptomonas spp. Diatoms were represented primarily by Fragilaria species, and most of the diatoms and cyanobacteria observed in August were gone by October, with the exception of Melosira granulata.

Samples collected during July and September 2002 were very different than other years (table 28 in "Supplemental Information" section of this report). In particular, two species of filamentous cyanobacteria, Oscillatoria spp. and Lyngbya limnet$i c a$, were dominant in the July hypolimnion sample, and although they are not nitrogen fixers, they are capable of producing taste and odors ("musty odor") (Palmer, 1977). Lakebottom samples (hypolimnion) collected during September 2002 consisted of 71 percent Euglena spp., along with Synedra spp. that were common in both July and September 2002. A predominance of Euglena species often is associated with organically enriched water (Wetzel, 2001, p. 338). The 71-percent dominance of Euglena spp. in the September lakebottom sample is consistent with low-light requirements and high levels of carbon (Wetzel, 2001, p. 337-338), possibly from dead algae that sank following a bloom. 


\section{Occurrence and Implications of Microcystis}

Microcystis is a cyanobacterial genus that includes toxic and nontoxic species (Chorus and Bartram, 1999, p. 49). Toxic species can synthesize microcystin, a hepatotoxin that can be of great concern to humans and wildlife if it occurs in drinkingwater reservoirs or recreational areas (Chorus and Bartram, 1999, p. 42). Globally, the most frequently identified cyanobacterial toxins in fresh and brackish water have been found in blooms of Microcystis and Nodularia (Chorus and Bartram, 1999).

In temperate regions of the United States, the occurrence of cyanobacteria and the potential presence of microcystin are most common during late summer and early autumn and may last 2 to 4 months. Blooms of Microcystis typically are found in lakes with an average summer chlorophyll- $a$ concentration of 20 to $50 \mu \mathrm{g} / \mathrm{L}$ and a Secchi depth of 3 to $6 \mathrm{ft}$ (Chorus and Bartram, 1999).

Microcystins are extremely stable and chemically resistant to breakdown (Chorus and Bartram, 1999, p. 43). They appear to be weakly retained on suspended solids in rivers and reservoirs, and usually no more than 20 percent of the microcystin concentration is adsorbed. Chemical breakdown of microcystin can take 10 to 12 weeks for 90-percent breakdown, but breakdown is enhanced in the presence of humic substances and other pigments in the water (Chorus and Bartram, 1999).

There are many strains of microcystin and more than one toxic-producing species of Microcystis (Chorus and Bartram,
1999, p. 46-48). Microcystin-LR, a toxic algal compound, was evaluated in this study not necessarily because it is the most common microcystin found in nature but because it was one of the first to have a chemical standard for analysis established and available commercially. The World Health Organization (WHO) has established drinking-water quality guidelines for microcystin-LR not to exceed $1.0 \mu \mathrm{g} / \mathrm{L}$ (Chorus and Bartram, 1999). Concentrations of microcystin-LR in Lake Olathe during 2002 ranged from less than 0.1 to $0.41 \mu \mathrm{g} / \mathrm{L}$ and, therefore, do not appear to pose any significant health risk on the basis of the WHO guidelines (fig. 14). It is interesting that the smallest concentrations of microcystin-LR occurred in September and October 2002 (0.24 and less than $0.1 \mu \mathrm{g} / \mathrm{L}$, respectively) when actinomycetes and geosmin concentrations were large. It is possible that during this period either biological competition favored actinomycetes, a filamentous bacteria (to be discussed in "Relation to Actinomycetes" section of this report), rather than cyanobacteria or that environmental conditions were more favorable for actinomycetes.

\section{Taste-and-Odor Occurrences in Lake Olathe}

Taste-and-odor problems are common in eutrophic surface water throughout the world. Sources range from inorganic compounds such as iron, manganese, and sulfides to organic compounds that include humic substances, hydrophilic acids, carboxylic acids, and hydrocarbons (Thurman, 1985). Many of

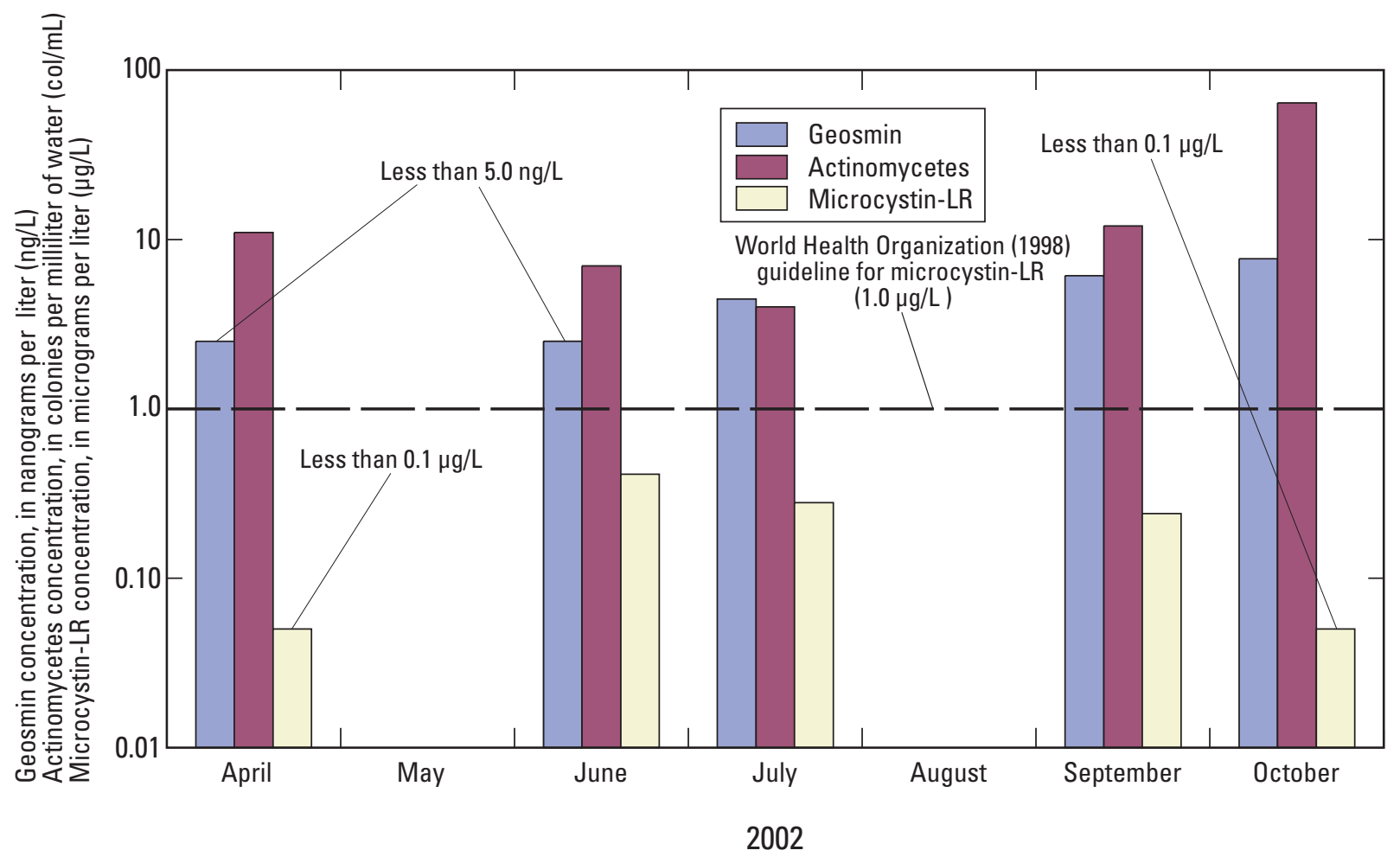

Figure 14. Concentrations of geosmin, actinomycetes, and microcystin in Lake Olathe near dam (site 2), April-0ctober 2002. 


\section{Surface-Water-Quality Conditions and Relation to Taste-and-Odor Occurrences in the Lake Olathe Watershed, Northeast Kansas, 2000-02}

the taste-and-odor-causing organic compounds in natural surface water can be traced to the decay of plant materials and the storage products of living microbiota. In fact, water-utility personnel in the United States surveyed in the 1950s listed algae (82 percent) and decaying vegetation (67 percent) as the two major causes of taste and odors in their systems

(Sigworth, 1957).

Since the 1950s many studies have been done in lakes and reservoirs to determine the compounds causing taste-and-odor problems, the conditions favorable to growth of organisms associated with taste-and-odor problems, and measures to remediate taste-and-odor problems (Mallevialle and Suffet, 1987). Results of these studies indicated that many algal species are capable of producing tastes and odors, including various Bacillariophyta, Chlorophyta, Cryptophyta, and actinomycetes. However, some of the most severe taste-and-odor problems were associated with blooms of cyanobacteria. Further studies showed that two chemical compounds found within particular species of cyanobacteria, geosmin and 2-methylisoborneol (MIB), were responsible for the taste-and-odor problems (Gerber, 1969; Tabachek and Yurkowski, 1976). Smith and deNoyelles (2001) provide a good summary of the history and background of taste-and-odor compounds in surface water.

Taste-and-odor problems in Kansas reservoirs have been found to be directly linked to the reservoirs' trophic state (Smith and deNoyelles, 2001). In a study of six eastern Kansas reservoirs, Arruda and Fromm (1989) determined that odor problems in these reservoirs were associated with a variety of algal species including Anabaena, a cyanobacterial species. Large concentrations of geosmin associated with cyanobacteria algal blooms have occurred in Clinton Lake (fig. 1) in northeast Kansas and have been related to nutrient and chlorophyll concentrations in the lake (Wang and others, 2000). Similarly, a study of Cheney Reservoir (fig. 1) in south-central Kansas showed a strong positive correlation between cyanobacteria biomass and peak geosmin concentrations (Smith and deNoyelles, 2001).

\section{Estimation of Taste-and-Odor Occurrences}

Many species of phytoplankton are known to be associated with taste-and-odor problems in lakes. Species of four tasteand-odor associated phytoplankton were identified in Lake Olathe during different times of the year, and statistical models for these species were developed using least-squares regression analysis. The four species-Melosira granulata, Anabaena, Oscillatoria, and Cryptomonas - produce musty, violet smelling, musty, and grassy odors, respectively, in water (Palmer, 1977).

The water residence time of Lake Olathe was a significant independent variable in the statistical model developed for the diatom Melosira granulata (table 6):

MELGRA $=(12.61 \cos 2 \pi \mathrm{D} / 365+0.17 \sin 2 \pi \mathrm{D} / 365)-$ 0.21 Residence +0.22 Turb +14.08 , where

MELGRA is the diatom Melosira granulata, in relative percentage abundance;

$\cos 2 \pi \mathrm{D} / 365$ is a seasonality term, in days (D is Julian day of year);

$\sin 2 \pi \mathrm{D} / 365$ is a seasonality term, in days ( $\mathrm{D}$ is Julian day of year);

Residence is number of continuous days Lake Olathe elevation less than $937.5 \mathrm{ft}$ prior to sampling, in days; and

Turb is the continuous turbidity measurement at time of sample collection, in nephelometric turbidity units.

Residence time was negatively correlated, and seasonality and turbidity were positively correlated with the relative biovolume of Melosira granulata, indicating that this diatom was more dominant during the spring when the residence time was short but turbidity was large, and that it may be responsible for some of the musty taste-and-odor problems that Lake Olathe has experienced. The coefficient of determination $\left(\mathrm{R}^{2}\right)$ and $p$-value for the Melosira granulata model were 0.89 and less than 0.001 (table 6), respectively, indicating a statistically significant relation was developed for determining the relative percentage abundance of Melosira granulata using these variables.

The ability of Anabaena, a genus of cyanobacteria, to regulate its buoyancy and move through the water column gives it distinct competitive advantages over other species of phytoplankton in finding optimal conditions of sunlight and nutrients during periods when lake turbidity is high. The statistical model for Anabaena indicated that turbidity was a positively correlated independent variable for Anabaena and, conversely, that specific conductance was a negatively correlated independent variable (table 6).

$$
\text { ANABSPP=0.66Turb }-0.16 \mathrm{SC}-58.99 \mathrm{TKN}+125.2 \text {, }
$$

where

ANABSPP is the cyanobacteria species Anabaena, in relative percentage abundance;

Turb is the continuous turbidity measurement at time of sample collection, in nephelometric turbidity units;

$\mathrm{SC}$ is the continuous specific conductance measurement at time of sample collection, in microsiemens per centimeter at 25 degrees Celsius; and

TKN is total ammonia plus organic nitrogen as nitrogen, in milligrams per liter.

Typically, in the Lake Olathe watershed, specific conductance and turbidity are inversely related. Runoff from storms in the watershed increases discharge and turbidity and decreases specific conductance. When storm runoff from Cedar Creek reaches Lake Olathe, suspended sediment in water settles to the lake bottom causing shifts in the phytoplankton community structure. There also was a significant decrease in TKN associated with the increase in Anabaena, which suggests that TKN 
may have been used as a primary food source. The coefficient of determination $\left(\mathrm{R}^{2}\right)$ and $p$-value for the Anabaena model were 0.64 and 0.014 (table 6), respectively, indicating a statistically significant relation for determining the biovolume of Anabaena using these variables.

Another cyanobacteria species associated with musty odors in drinking water, Oscillatoria, was positively correlated with turbidity and TKN but inversely correlated with the residence time (table 6):

$$
\text { OSCISP=0.06Turb - 0.03Residence+2.97(TKN) }-2.54 \text {, }
$$

where

OSCISP is the cyanobacteria species Oscillatoria, in relative percentage abundance;

Turb is the continuous turbidity measurement at time of sample collection, in nephelometric turbidity units;

Residence is number of continuous days Lake Olathe elevation less than $937.5 \mathrm{ft}$ prior to sampling, in days; and

TKN is the total ammonia plus organic nitrogen as nitrogen, in milligrams per liter.

Increased turbidity in conjunction with reduced residence time in Lake Olathe suggests dominance of Oscillatoria during the spring when these conditions are present along with potential musty taste-and-odor problems in the drinking water. The coefficient of determination $\left(\mathrm{R}^{2}\right)$ and $p$-value for the statistical model for Oscillatoria were 0.75 and 0.001 (table 6), respectively, indicating a statistically significant relation was developed in determining the relative percentage abundance of Oscillatoria using these variables.

The statistical model developed for Cryptomonas included explanatory variables representing the time of year (seasonality), along with specific conductance and continuous fluorescence (table 6):

$$
\begin{gathered}
\text { CRYPTSPP }=(20.81 \sin 2 \pi \mathrm{D} / 365+22.87 \cos 2 \pi \mathrm{D} / 365)-285.8 \\
\log (\mathrm{SC})+30.1(\text { FLUOR })+758,
\end{gathered}
$$

where

CRYPTSPP is the phytoplankton species Cryptomonas, in relative percentage abundance;

$\cos 2 \pi \mathrm{D} / 365$ is a seasonality term, in days ( $\mathrm{D}$ is Julian day of year);

$\sin 2 \pi \mathrm{D} / 365$ is a seasonality term, in days ( $\mathrm{D}$ is Julian day of year);

SC is the continuous specific conductance measurement at time of sample collection, in microsiemens per centimeter at $25^{\circ} \mathrm{C}$; and

FLUOR is the continuous fluorescence at time of sample collection, in micrograms per liter.

As stated previously, increases in Cryptomonas frequently are seen immediately following the demise of dominant algal blooms (Wetzel, 2001). They are found in almost all lakes, regardless of trophic state, but usually are present in small numbers. The negative relation of Cryptomonas to specific conductance in Lake Olathe suggests that this species may prefer more turbid water conditions that occur during the spring each year. The positive relation of Cryptomonas to real-time continuous fluorescence also suggests that this species is more dominant during the spring and may be responsible for some of the taste-and-odor problems that occur in Lake Olathe during the spring. The coefficient of determination $\left(\mathrm{R}^{2}\right)$ and $p$-value for the Cryptomonas model were 0.73 and 0.007 , respectively, indicating a statistically significant relation for determining the biovolume of Cryptomonas using these variables.

\section{Relation to Actinomycetes}

Actinomycetes are filamentous bacteria that produce spores and are one of two life forms responsible for the degradation of cellulose in forests (Mallevialle and Suffet, 1987, p. 59). Actinomycetes have been recognized for years as producers of compounds responsible for muddy tastes in fish (Mallevialle and Suffet, 1987, p. 59). Other taste-and-odor compounds, notably geosmin and MIB, have been isolated from actinomycetes in addition to compounds that produce a variety of odors, including earthy, woody, musty, potato-bin-like, haylike, fishy, and grassy (Mallevialle and Suffet, 1987). Collection of water samples for the analysis of actinomycetes occurred only during 2002.

The extent to which actinomycetes cause taste-and-odor occurrences in water supplies is difficult to determine. They grow slowly, and the number of actinomycetes appearing on agar plates usually does not correlate with the odor intensities in the water supply because both actinomycetes filaments and spores produce colonies that proliferate best in sediment and around the shoreline (Mallevialle and Suffet, 1987). Therefore, although actinomycetes may be the source of earthy, musty taste-and-odor problems, the number of episodes caused by actinomycetes is likely to be small compared to taste-and-odor problems caused by algae.

Actinomycetes concentrations in Cedar Creek during a storm period on May 12, 2002, were two orders of magnitude larger than the largest actinomycetes concentrations detected from the epilimnion of Lake Olathe during 2002 (2,300 and $64 \mathrm{col} / \mathrm{mL}$, respectively) (table 20). Storm runoff in Cedar Creek typically transports large suspended-sediment loads; therefore, it is not surprising that large concentrations of actinomycetes would be detected because of the close association between sediment and actinomycetes. In addition, elevated concentrations of geosmin and MIB would be expected during storm runoff because actinomycetes are known producers of these compounds (Mallevialle and Suffet, 1987). However, concentrations of geosmin and MIB were not as elevated as expected in Cedar Creek on May 12, 2002, with detections of 8.1 and $11 \mathrm{ng} / \mathrm{L}$, respectively (table 20 and data on file at USGS office in Lawrence, Kansas).

Concentrations of actinomycetes in Lake Olathe during 2002 were small with the exception of October 30, 2002 


\section{Surface-Water-Quality Conditions and Relation to Taste-and-Odor Occurrences in the Lake Olathe Watershed, Northeast Kansas, 2000-02}

(fig. 14). Concentrations ranged from 4 to $64 \mathrm{col} / \mathrm{mL}$, and the larger concentrations reported in September and October 2002 (12 and $64 \mathrm{col} / \mathrm{mL}$, respectively) were coincident with detectable concentrations of geosmin (fig. 14). Cyanobacteria capable of producing geosmin were noticeably absent in September 2002 (fig. 13), a period when there were frequent tasteand-odor complaints from Olathe residents being served from this water supply. It is apparent that geosmin is an important cause of taste-and-odor complaints, but there also may be other factors contributing to taste and odor in Lake Olathe. It is possible that during this period geosmin was produced by actinomycetes or other unidentified algae or bacteria not associated with cyanobacteria. Although Melosira, Cryptomonas, and Oscillatoria were present in September 2002 samples (table 28 at the back of this report), the concentrations of these phytoplankton probably were not large enough to cause the frequent taste-and-odor complaints.

\section{Statistical Models for Estimation of Geosmin}

Developing statistical relations for geosmin using continuous real-time water-quality constituents was difficult because of infrequent geosmin detections. Lake Olathe (Lake Olathe near dam and Lake Olathe at upstream end) was sampled 24 times during June 2000 through December 31, 2002 (table 20), and geosmin was detected at concentrations greater than the laboratory minimum detection level of $5.0 \mathrm{ng} / \mathrm{L}$ in 12 of the samples. One-half of the detection level for geosmin, $2.5 \mathrm{ng} / \mathrm{L}$, was used in the statistical models of this study for the 12 samples with results less than the detection level.

The least-squares regression model developed for geosmin used data from both continuous real-time water-quality constituents and water-quality sampling and measurements. The independent variables selected for the equation included Secchi depth, specific conductance, and turbidity. On the basis of the coefficient of determination $\left(\mathrm{R}^{2}\right), p$-values for the individual variables, mean square error, and t-statistic, the following equation was developed (table 6):

$$
\text { geosmin=1.08Secchi }-0.064 \mathrm{SC}+0.24 \mathrm{Turb}+31.04 \text {, }
$$

where

geosmin is an earthy taste-and-odor compound in water, in nanograms per liter;

Secchi is the Secchi depth, in feet;

$\mathrm{SC}$ is the continuous specific conductance measurement, in microsiemens per centimeter at $25^{\circ} \mathrm{C}$; and

Turb is the continuous turbidity measurement, in nephelometric turbidity units.

The analysis indicates that geosmin concentrations in Lake Olathe increase following periods of rainfall and runoff, as reflected by increases in turbidity (wash-in of soils and other substances from the watershed) and concomitant decreases in specific conductance, a result of dilution from rain water with small solute concentrations. This relation is consistent with a hypothesis that earthy or musty odors in Lake Olathe during 2000-02 were associated with the wash-in of soils and associated microorganisms such as actinomycetes. Thus, the source of tastes and odors may be external to the lake rather than a result of internal eutrophication processes.

The coefficient of determination $\left(\mathrm{R}^{2}\right)$ for the least-squares regression equation, 0.70 ( $p$-value $=0.0016)$, indicated a statistically significant relation for geosmin using Secchi depth, specific conductance, and turbidity. However, with the limited data set it was not feasible to develop statistically valid regression equations using only continuous real-time parameters.

\section{Summary}

Surface-water-quality conditions and relations with tasteand-odor occurrences were investigated in the Lake Olathe watershed in northeast Kansas during 2000-02. One site on Cedar Creek and two sites in Lake Olathe were sampled from June 2000 to December 2002 to characterize the water quality in relation to major ions, nutrients, selected trace elements, selected pesticides, fecal indicator bacteria, phytoplankton, and taste-and-odor compounds. Water-quality sampling was conducted both seasonally and under varying hydrologic conditions to evaluate watershed processes. In addition, continuous realtime water-quality monitors were installed in 2000 in Cedar Creek and Lake Olathe, and data from these instruments were used to develop surrogate relations for selected compounds.

Nutrients are essential for the growth and reproduction of plants, but excess nutrient enrichment to a lake increases the rate of eutrophication and can lead to excessive growth of algae and other aquatic plants. The mean and median concentrations of the various forms of nitrogen were larger in samples from Cedar Creek than in samples from the epilimnion of Lake Olathe, indicating that the source of nitrogen was the watershed and that nutrients were transported to the lake by Cedar Creek. Median total phosphorus concentrations in water from Cedar Creek were more than two times greater than in samples from the epilimnion of Lake Olathe, indicating that the primary source of phosphorus enrichment to the lake was the watershed. However, increased concentrations of phosphorus in samples from the hypolimnion of Lake Olathe also indicated internal loading of phosphorus as phosphorus is released from the bottom sediment.

In addition to boron, two trace elements, iron and manganese, were monitored in both Cedar Creek and Lake Olathe. Because increased concentrations of these elements can cause taste and odor in drinking water, USEPA has established Secondary Drinking Water Reguations for treated water of 300 and $50 \mu \mathrm{g} / \mathrm{L}$ for iron and manganese, respectively. The median concentrations of both iron and manganese in the epilimnion of Lake Olathe, less than 10 and less than $1 \mu \mathrm{g} / \mathrm{L}$, respectively, were substantially less than the criteria; however, manganese 
concentrations as large as $3,100 \mu \mathrm{g} / \mathrm{L}$ were detected in samples from the lake hypolimnion.

Fifty pesticides, including herbicides and insecticides, were analyzed in water samples from Cedar Creek and Lake Olathe, and 10 pesticides were detected at concentrations greater than $0.01 \mu \mathrm{g} / \mathrm{L}$. Four of the pesticides or degradation products, all herbicides used to control broadleaf weeds and grasses, were detected at concentrations greater than $1.0 \mu \mathrm{g} / \mathrm{L}$ in samples from Cedar Creek. In particular, atrazine, a preemergent herbicide applied to corn and other crops, was detected frequently. Atrazine concentrations varied seasonally, and concentrations were larger during the late spring and summer, coinciding with agricultural application, than in the early spring, fall, and winter. Concentrations of atrazine did not exceed the chronic aquatic-life criteria of $3.0 \mu \mathrm{g} / \mathrm{L}$ or the annual average USEPA Maximum Contaminant Level for drinking water of $3.0 \mu \mathrm{g} / \mathrm{L}$ during 2001 and 2002; however, concentrations in single samples did exceed these criteria.

Nutrient loads and yields for forms of nitrogen and phosphorus were estimated using regression analysis. The soluble fraction of nitrogen, represented by nitrite plus nitrate as nitrogen, accounted for nearly 50 percent of the total nutrient load to Lake Olathe during 2001 and 2002. The mean annual orthophosphate load, the fraction of total phosphorus that can be utilized directly by algae and other aquatic plants, represented 29 percent of the total phosphorus load. Loading of orthophosphate to Lake Olathe can lead to algal blooms and taste-andodor problems in the drinking water. Mean annual yields of both total nitrogen and total phosphorus in Lake Olathe, 13.0 and $1.1 \mathrm{lb} / \mathrm{acre}$, respectively, were similar to other watersheds characterized by mixed-agricultural land-use practices.

Nutrient ratios were computed to better understand whether nitrogen or phosphorus concentrations are limiting algal production in Lake Olathe. The analysis indicated that algal growth in Lake Olathe may have been limited by phosphorus throughout much of the year and that lake turbidity was caused primarily by silt and clay particles washed in from the watershed. Light availability also could be a factor that limits algal productivity and water clarity as estimated by water turbidity.

Trophic state analysis of Lake Olathe, which is based on a classification system used by the Kansas Department of Health and Environment (KDHE) to establish a lake-use impairment identification system, indicated that Lake Olathe was eutrophic on the basis of large concentrations of chlorophyll. Carlson's mean annual trophic-state indices for Lake Olathe for 2000-02, which are based on algal biomass measured by either chlorophyll- $a$ or total phosphorus concentrations, were 55 and 63, indicating eutrophic conditions in the lake. Trophic response also was evaluated for Lake Olathe using an empirical model developed by Vollenweider to measure the total phosphorus entering and retained in the lake. The model was not sufficiently robust and computed total phosphorus concentrations 10 times less than the observed mean total phosphorus concentration, suggesting that other models might better explain nutrient conditions in Lake Olathe.

Fecal coliform bacteria densities in samples from Cedar Creek exceeded KDHE (2001) secondary contact criterion of $2,000 \mathrm{col} / 100 \mathrm{~mL}$ water for any single sample in four of the seven storm-runoff samples collected from 2000 through 2002. The KDHE criterion also was exceeded in samples from Cedar Creek during periods of low flow in July and October 2000.

The current (2004) KDHE criterion, which is based on the geometric mean of five Escherichia coli (E. coli) samples collected during 30 days, was not evaluated in this study. Concentrations of fecal coliform bacteria in samples from Lake Olathe were less than primary and secondary single-sample criteria for recreational waters in Kansas. Swimming is not allowed in Lake Olathe, so the primary contact recreation criterion that describes full-body contact with water probably does not apply.

Microcystin-LR, a toxic algal compound, was sampled and analyzed in water from Cedar Creek and Lake Olathe during 2002. Concentrations of the compound ranged from 0.1 to $0.41 \mu \mathrm{g} / \mathrm{L}$. On the basis of World Health Organization drinking-water guidelines of $1.0 \mu \mathrm{g} / \mathrm{L}$, these concentrations do not appear to pose any health-associated risks at present.

Phytoplankton taxa were identified in samples from both Cedar Creek and Lake Olathe. There were instances when as many as seven algal divisions were identified, but typically Bacillariophyta, Chlorophyta, and cyanobacteria, represented 90 percent or more of all taxa. Some of the taxa identified in Lake Olathe, such as Asterionella formosa (Bacillariophyta), Oscillatoria spp. (cyanobacteria), and Lyngbya limnetica (cyanobacteria) are known producers of taste-and-odor compounds that may be responsible for problems associated with the Lake Olathe drinking-water supply.

Regression models were developed for four taste-and-odor associated phytoplankton species detected frequently in Lake Olathe-Melosira granulata, Anabaena, Oscillatoria, and Cryptomonas. The coefficients of determination, $\mathrm{R}^{2}$, ranged from 0.64 to 0.89 , and $p$-values ranged from less than 0.001 to 0.014 , indicating a statistically significant relation with the chosen variables.

In 2002, water from Cedar Creek and Lake Olathe was sampled and analyzed for actinomycetes, a known producer of geosmin and 2-methylisoborneol (MIB). During 2002, Lake Olathe actinomycetes concentrations ranged from 4 to $64 \mathrm{col} / \mathrm{mL}$ water, and geosmin concentrations ranged from less than 5.0 to $12.0 \mathrm{ng} / \mathrm{L}$.

Two chemicals associated with cyanobacteria and many of the most severe taste-and-odor problems in lakes and reservoirs, geosmin and MIB, were detected in Lake Olathe. Detections of MIB were infrequent, and as a result regression analysis was not done using this chemical; however, a regression model was developed for geosmin using Secchi depth, specific conductance, and turbidity. The coefficient of determination, $\mathrm{R}^{2}$, was 0.70 , and the $p$-value was 0.0016 , indicating a statistically significant relation using these variables. However, the use of 


\section{Surface-Water-Quality Conditions and Relation to Taste-and-Odor Occurrences in the Lake Olathe Watershed, Northeast Kansas, 2000-02}

Secchi transparency depth in the model prevented model development using only continuous real-time water-quality constituents and thus limits the model's predictive utility.

\section{References}

American Public Health Association, American Water Works Association, and Water Pollution Control Federation, 1985, Standard methods for the examination of water and wastewater (16th ed.): Washington, D.C., American Public Health Association, $905 \mathrm{p}$.

Arruda, J.A., and Fromm, C.H., 1989, The relationship between taste and odor problems and lake enrichment from Kansas lakes in agricultural watersheds: Lake and Reservoir Management, v. 5, no. 1, p. 45-52.

Aspelin, A.L., Grube, A.H., and Toria, R., 1992, Pesticide industry sales and usage, 1990 and 1991 market estimates: Washington, D.C., U.S. Environmental Protection Agency, $37 \mathrm{p}$.

Bohn, C.C., and Buckhouse, J.C., 1985, Coliforms as an indicator of water quality in wildland streams: Journal of Soil and Water Conservation, v. 40, p. 95-97.

Britton, L.J., and Greeson, P.E., eds., 1989, Methods for collection and analysis of aquatic biological and microbiological samples: U.S. Geological Survey Techniques of WaterResources Investigations, book 5, chap. A4, 363 p.

Brower, J.E., Zar, J.H., and von Ende, C.N., 1998, Field and laboratory methods for general ecology (4th ed.): New York, McGraw-Hill, 273 p.

Buchanan, T.J., and Somers, W.P., 1969, Discharge measurements at gaging stations: U.S. Geological Survey Techniques of Water-Resources Investigations, book 3, chap A8, $65 \mathrm{p}$.

Bushway, R.J., Perkins, B., Savage, S.A., Lekousi, S.L., and Ferguson, B.S., 1988, Determination of atrazine residues in water and soil by enzyme immunoassay: Bulletin Environmental Contamination and Toxicology, v. 42, p. 899-904.

Cabelli, V.J., 1977, Indicators of recreational water quality, in Hoadley, A.W., and Dutka, B.J., eds., Bacterial indicators/ health hazards associated with water, 1977: American Society for Testing and Materials, ASTM STP 635, p. 222-238.

Carlson, R.E., 1977, A trophic state index for lakes: Limnology and Oceanography, v. 22, no. 2, p. 361-369.

Carney, C.E., 1998, A primer on lake eutrophication and related pollution problems: Kansas Department of Health and Environment, Bureau of Environmental Field Services, 30 p.

Carney, C.E., 2001, Lake and wetland monitoring program 1999 annual report: Kansas Department of Health and Environment, Bureau of Environmental Field Services, 57 p.

Chorus, I., and Bartram, J., 1999, Toxic cyanobacteria in water-a guide to their public health consequences, monitoring and management: New York, E \& FN Spon, 416 p.

Christensen, V.G., 1999, Deposition of selenium and other constituents in reservoir bottom sediment of the Solomon River
Basin, north-central Kansas: U.S. Geological Survey WaterResources Investigations Report 99-4230, 46 p.

Christensen, V.G., Jian, Xiaodong, and Ziegler, A.C., 2000, Regression analysis and real-time water-quality monitoring to estimate constituent concentrations, loads, and yields in the Little Arkansas River, south-central Kansas, 1995-99: U.S. Geological Survey Water-Resources Investigations Report 00-4126, 36 p.

Cohn, T.A., DeLong, L.L., Gilroy, E.J., Hirsch, R.M., and Wells, D., 1989, Estimating constituent loads: Water Resources Research, v. 25, no. 5, p. 937-942.

Davis, J.C., 1986, Statistics and data analysis in geology: New York, John Wiley and Sons, p. 579-595.

Doran, J.W., and Linn, D.M., 1979, Bacteriological quality of runoff water from pastureland: Applied and Environmental Microbiology, v. 37, no. 5, p. 985-991.

Duan, N., 1983, Smearing estimate-a nonparametric retransformation method: Journal of the American Statistical Association, v. 78, p. 605-610.

Dufour, A.P., 1977, Escherichia coli-the fecal coliform, in Hoadley, A.W., and Dutka, B.J., eds., Bacterial indicators/ health hazards associated with water, 1977: American Society for Testing and Materials, ASTM STP 635, p. 48-58.

Dufour, A.P., and Cabelli, V.J., 1984, Health effects criteria for fresh recreational waters: Cincinnati, Ohio, U.S. Environmental Protection Agency, EPA 600/1-84-004, 33 p.

Eaton, A.D., Clesceri, L.S., and Greenberg, A.E., 1995, Standard methods for the examination of water and wastewater (19th ed.): Washington, D.C., American Public Health Association, various pagination.

Edwards, T.K., and Glysson, G.D., 1988, Field methods for measurement of fluvial sediment: U.S. Geological Survey Open-File Report 86-531, 118 p.

Faires, L.M., 1993, Methods of analysis by the U.S. Geological Survey National Water Quality Laboratory-determination of metals in water by inductively coupled plasma-mass spectrometry: U.S. Geological Survey Open-File Report 92-634, $28 \mathrm{p}$.

Fishman, M.J., and Friedman, L.C., 1989, Methods for determination of inorganic substances in water and fluvial sediments: U.S. Geological Survey Techniques of WaterResources Investigations, book 5, chap. A1, 545 p.

Gerber, N.N., 1969, A volatile metabolite of actinomycetes, 2methylisoborneol: Journal of Antibiotics, v. 22, p. 508.

Gerber, N.N., and Lechavalier, H.A., 1965, Geosmin, an earthy-smelling substance isolated from actinomycetes: Applied Microbiology, v. 13, p. 935.

Gleeson, C., and Gray, N.F., 1997, The coliform index and waterborne disease-problems of microbial drinking water assessment: London, E. and F.N. Spon, LTD., 210 p.

Guy, H.P., 1969, Laboratory theory and methods for sediment analysis: U.S. Geological Survey Techniques of WaterResources Investigations, book 5, chap. C1, 58 p.

Helsel, D.R., and Hirsch, R.M., 1992, Statistical methods in water resources: New York, Elsevier, 522 p. 
Hem, J.D., 1992, Study and interpretation of the chemical characteristics of natural water ( $3 \mathrm{~d}$ ed.): U.S. Geological Survey Water-Supply Paper 2254, 263 p.

Hirsch, R.M., Helsel, D.R., Cohn, T.A., and Gilroy, E.J., 1993, Statistical analysis of hydrologic data, in Maidment, D.R., ed., Handbook of hydrology: New York, McGraw-Hill, Inc., p. 17.1-17.55.

Holt, J.G., Krieg, N.R., Sneath, P.H.A., and others, eds., 1993, Bergey's manual of determinative bacteriology (9th ed.): Baltimore, Maryland, Williams and Wilkens, 787 p.

Horne, A.J., and Goldman, C.R., 1994, Limnology (2d ed.): New York, McGraw-Hill Inc., 576 p.

International Organization for Standardization (ISO), 1999, Water-quality determination of turbidity, method 7027 : Geneva, Switzerland, 18 p.

Journey, C.A., and Gill, A.C., 2001, Assessment of water-quality conditions in the J.B. Converse Lake watershed, Mobile County, Alabama, 1990-98: U.S. Geological Survey WaterResources Investigations Report 01-4225, 131 p.

Juracek, K.E., 1997, Analysis of bottom sediment to estimate nonpoint-source phosphorus loads for 1981-96 in Hillsdale Lake, northeast Kansas: U.S. Geological Survey WaterResources Investigations Report 97-4235, 55 p.

Juracek, K.E., 2003, Sediment deposition and occurrence of selected nutrients, other chemical constituents, and diatoms in bottom sediment, Perry Lake, northeast Kansas,

1969-2001: U.S. Geological Survey Water-Resources Investigations Report 03-4025, 56 p.

Juracek, K.E., and Mau, D.P., 2002, Sediment deposition and occurrence of selected nutrients and other chemical constituents in bottom sediment, Tuttle Creek Lake, northeast Kansas, 1962-99: U.S. Geological Survey Water-Resources Investigations Report 02-4048, 73 p.

Kansas Department of Agriculture and U.S. Department of Agriculture, 1996-2000, Kansas farm facts: Topeka, Kansas, published annually.

Kansas Department of Health and Environment, 2000, 2000 Kansas water quality assessment (305(b) report): Topeka, Kansas, Secretary of State, 42 p.

Kansas Department of Health and Environment, 2001, Kansas register, article 28-16-28e, Surface water quality standards: Topeka, Kansas, Secretary of State, 19 p.

Kansas Department of Health and Environment, 2003, Kansas register, article 28-16-28e, Surface water quality standards: Topeka, Kansas, Secretary of State, 22 p.

Kansas Geological Survey, 1993, Landcover metadata: Information available on World Wide Web, accessed May 9, 2000, at URL http://gisdata.kgs.ukans.edu/dasc/ catalog/coredata.html

Kansas State Board of Agriculture and U.S. Department of Agriculture, 1960-95, Kansas farm facts: Topeka, Kansas, published annually.

Kansas State University Research and Extension, 2003, Precipitation by county: Information available on World Wide Web, accessed August 12, 2003, at URL http://www.oznet.ksu.edu/wdl/wdl/pmaps.htm
Kansas Water Office, 2001, KWA reviews five key water issues: Hydrogram, winter 2001, p. 29-36.

Kennedy, E.J., 1984, Discharge ratings at gaging stations: U.S. Geological Survey Techniques of Water-Resources Investigations, book 3, chap. A10, 59 p.

Lee, G.F., and Sears, R.I., 1985, Kansas Clean Lakes Program, Lake Olathe: prepared for city of Olathe, Kansas, various pagination.

Lowe, R.L., 1974, Environmental requirements and pollution tolerance of freshwater diatoms: Cincinnati, Ohio, National Environmental Research Center, Office of Research and Development, U.S. Environmental Protection Agency, EPA-670/4-74-005, 334 p.

Lund, J.W.G., Kipling, C., and LeCren, E.D., 1958, The inverted microscope method of estimating algal numbers and the statistical basis of estimates by counting: Hydrobiologia, v. 11, p. 143-170.

Mallevialle, J., and Suffet, I.H., eds., 1987, Identification and treatment of tastes and odors in drinking water: American Water Works Association Research Foundation, 292 p.

MathSoft, Inc., 1999, S-Plus 2000, modern statistics and advanced graphics, users guide: Cambridge, Massachusetts, $558 \mathrm{p}$.

Mau, D.P., 2002, Sediment deposition and selected water-quality characteristics in Cedar Lake and Lake Olathe, northeast Kansas, 2000: U.S. Geological Survey Water-Resources Investigations Report 02-4073, $71 \mathrm{p}$.

Mau, D.P., and Christensen, V.G., 2000, Comparison of sediment deposition in reservoirs of four Kansas watersheds: U.S. Geological Survey Fact Sheet 102-00, 4 p.

Meade, R.H., ed., 1995, Contaminants in the Mississippi River, 1987-92: U.S. Geological Survey Circular 1133, 140 p.

Meyer, J.L., and Likens, G.E., 1979, Transport and transformation of phosphorus in a forest stream ecosystem: Ecology, v. 60 , p. $1225-1269$.

Morris, L.M., and Fan, J.,1998, Reservoir sedimentation handbook: New York, McGraw-Hill, p. 4.18.

Myers, D.N., and Wilde, F. D., eds., 1999, National field manual for the collection of water-quality data-biological indicators: U.S. Geological Survey Techniques of WaterResources Investigations, book 9, chap. A7, 52 p.

National Oceanic and Atmospheric Administration, 1973-2002, Climatological data annual summary-eastcentral Kansas: Asheville, North Carolina, National Weather Service Climatic Data Center, published monthly.

National Research Council, 2000, Clean coastal watersunderstanding and reducing the effects of nutrient pollution: Washington, D.C., National Academy Press, 428 p.

Naumann, E., 1929, The scope and chief problems of regional limnology: International Revue ges. Hydrobiology, v. 21, p. 423-444.

Olathe Chamber of Commerce, 2002, Olathe Convention and Visitors Bureau: Information available on the World Wide Web, accessed May 24, 2004, at URL http://www.olathe.org/olathe_cvb/ 
Palmer, C.M., 1977, Algae and water pollution: Cincinnati, Ohio, U.S. Environmental Protection Agency, EPA-600/9-77-036.

Patton, C.J., and Truitt, E.P., 1992, Methods of analysis by the U.S. Geological Survey National Water Quality Laboratory-determination of total phosphorus by a Kjeldahl digestion method and an automated colorimetric finish that includes dialysis: U.S. Geological Survey OpenFile Report 92-146, 39 p.

Pepper, I.L., Gerba, C.P., and Brusseau, M.L., eds., 1996, Pollution science: New York, Academic Press, 397 p.

Pope, L.M., Brewer, L.D., Foley, G.A., and Morgan, S.C., 1997, Concentrations and transport of atrazine in the Delaware River-Perry Lake system, northeast Kansas, July 1992 through September 1995: U.S. Geological Survey WaterSupply Paper 2489, 43 p.

Prescott, G.W., 1962, Algae of the western Great Lakes area: Dubuque, Iowa, William C. Brown Co. Publ., 977 p.

Putnam, J.E., Lacock, D.L., and Schneider, D.R., 2002, Water resources data—Kansas, water year 2001: U.S. Geological Survey Water-Data Report KS-01-1, 532 p.

Putnam, J.E., and Schneider, D.R., 2003, Water resources data-Kansas, water year 2002: U.S. Geological Survey Water-Data Report KS-02-1, 539 p.

Rasmussen, P.P., Shockley, J.C., and Hargadine, D.A., 1994, Hydrogeology and water-quality conditions at the city of Olathe landfill, east-central Kansas, 1990-93: U.S. Geological Survey Water-Resources Investigations Report 94-4166, $44 \mathrm{p}$.

Rasmussen, P.P., and Ziegler, A.C., 2003, Comparison and continuous estimates of fecal coliform and Escherichia coli bacteria in selected Kansas streams, May 1999 through April 2002: U.S. Geological Survey Water-Resources Investigations Report 03-4056, 80 p.

Reckhow, K.H., Beaulac, M.N., and Simpson, J.T., 1980, Modeling phosphorus loading and lake response under uncertainty-a manual and compilation of export coefficients: U.S. Environmental Protection Agency, Office of Water Regulations and Standards, EPA 440/5-80-011, 214 p.

Sadar, M.J., 2002, Turbidity instrumentation-an overview of today's available technology, in U.S. Geological Survey Turbidity and Other Surrogates Workshop, April 30-May 2, 2002, Reno, Nevada: Subcommittee on Sedimentation, information available on the World Wide Web, accessed August 12, 2003, at URL http://water.usgs.gov/osw/ techniques/TSS/sadar.pdf

Scheffer, M., 1998, Ecology of shallow lakes: New York, Chapman \& Hall Publ., 357 p.

Sigworth, E.A., 1957, Control of odor and taste in water supplies: Journal of American Water Works Association, v. 12, p. $1507-1521$.

Simpson, E.H., 1949, Measurement of diversity: Nature, v. 163, p. 688.

Smith, V.H., and deNoyelles, F., 2001, A comparative water quality study of Cheney Reservoir, Kansas: Lawrence, University of Kansas Department of Civil and Environmental
Engineering, final report to Wichita Water and Sewer

Department, $56 \mathrm{p}$.

Sprague, L.A., 2002, Nutrient dynamics in five off-stream reservoirs in the lower South Platte River Basin, MarchSeptember 1995: U.S. Geological Survey Water-Resources Investigations Report 02-4142, $72 \mathrm{p}$.

Sullivan, D.J., 1999, Nutrients and suspended solids in surface waters of the upper Illinois River Basin in Illinois, Indiana, and Wisconsin, 1978-97: U.S. Geological Survey WaterResources Investigations Report 99-4275, 57 p.

Tabachek, J.L., and Yurkowski, M., 1976, Isolation and identification of blue-green algae producing muddy odor metabolites, geosmin and 2-methylisoborneol, in saline lakes in Manitoba: Journal of Fishery Research Board Canada, v. 33, p. 25-38.

Thurman, E.M., 1985, Humic substances in groundwater, chapter 3, in Aiken, G.R., MacCarthy, P., McKnight, D.M., and Wershaw, R.L., eds., Humic substances in soil and water-geochemistry and analysis: New York, John Wiley and Sons, p. 87-103.

U.S. Department of Agriculture, 1992, Agricultural resources-inputs situation and outlook: Economic Research Service Publication AR-25, February 1992, 66 p.

U.S. Environmental Protection Agency, 1986, Quality criteria for water, 1986: U.S. Environmental Protection Agency Report 440/5-86-001, unnumbered pages.

U.S. Environmental Protection Agency, 1990, The lake and reservoir restoration guidance manual: U.S. Environmental Protection Agency, Office of Water, Report EPA-440/4-90-006, various pagination.

U.S. Environmental Protection Agency, 2000, Ambient waterquality criteria recommendations_-rivers and streams in Nutrient Ecoregion IX: U.S. Environmental Protection Agency Report 822-B-00-019, various pagination.

U.S. Environmental Protection Agency, 2002, Implementation guidance for ambient water quality criteria for bacteria, May 2002 draft: U.S. Environmental Protection Agency, Report EPA-823-B-02-003, information available on the World Wide Web, accessed June 16, 2003, at URL http://www.epa.gov/ostwater/standards/bacteria/

U.S. Environmental Protection Agency, 2003, National primary drinking water standards, June 2003: U.S. Environmental Protection Agency, Report EPA-816-F-03-016, information available on World Wide Web, accessed August 12, 2003, at URL http://www.epa.gov/safewater/mcl.html\#mcls

U.S. Geological Survey, 2001, Pesticides in streams, summary statistics, results of the National Water Quality Assessment Program (NAWQA), 1992-1998: U.S. Geological Survey, data available on the World Wide Web, accessed June 19, 2003, at URL http://ca.water.usgs.gov/pnsp/pestsw/ Pest-SW_2001_Text.html

Vollenweider, R.A., 1975, Input-output models, with special reference to the phosphorus loading concept in limnology: Swiss Journal of Hydrology, v. 37, p. 53-84. 
Wagner, R.J., Mattraw, H.C., Ritz, G.F., and Smith, B.A., 2000, Guidelines and standard procedures for continuous waterquality monitors-site selection, field operations, calibration, record computation, and reporting: U.S. Geological Survey Water-Resources Investigations Report 00-4252, $53 \mathrm{p}$.

Wang, S.H., Huggins, D.G., deNoyelles, F., Meyer, J.O., and Lennon, J.T., 2000, Assessment of Clinton Lake and its watershed, water quality and plankton communities in Clinton Lake, Kansas, May 1997 through November 1998: Lawrence, Kansas Biological Survey, 95 p.

Weber, C.I., 1971, A guide to the common diatoms at water pollution surveillance system stations: Cincinnati, Ohio, U.S. Environmental Protection Agency, National Environmental Research Center, Analytical Quality Control Laboratory, p. 19-22.

Wetzel, R.G., 2001, Limnology lake and river ecosystems (3d ed): San Diego, California, Academic Press, 1006 p.

Wilde, F.D, and Radtke, D.B., eds., 1998, National field manual for the collection of water-quality data: U.S. Geological Survey Techniques in Water-Resources Investigations, book 9 , chap. A6, various pagination.

Wilde, F.D, Schertz, T.L., and Radtke, D.B., 1999, Qualitycontrol samples: U.S. Geological Survey Techniques in Water-Resources Investigations, book 9, chap. A4, p. 91-103.
World Health Organization, 1998, Guidelines for drinkingwater quality ( $2 \mathrm{~d}$ ed.): Geneva, Switzerland, $31 \mathrm{p}$.

Zaugg, S.D., Sandstrom, M.W., Smith, S.G., and Fehlberg, K.M., 1995, Methods of analysis by the U.S. Geological Survey National Water Quality Laboratory-determination of pesticides in water by $\mathrm{C}-18$ solid-phase extraction and capillary-column gas chromatography/mass spectrometry with selected-ion monitoring: U.S. Geological Survey Open-File Report 95-181, $60 \mathrm{p}$.

Ziegler, A.C., 2002, Issues related to use of turbidity measurements as a surrogate for suspended sediment, in U.S. Geological Survey Turbidity and Other Surrogates Workshop, April 30-May 2, 2002, Reno, Nevada: Subcommittee on Sedimentation, information available on the World Wide Web, accessed August 12, 2003, at URL http://water.usgs.gov/osw/techniques/TSS/ZieglerT.pdf

Zimmerman, L.R., Ziegler, A.C., and Thurman, E.M., 2002, Method of analysis and quality-assurance practices by U.S. Geological Survey Organic Geochemistry Research Group-determination of geosmin and methylisoborneol in water using solid-phase microextraction and gas chromatography/mass spectrometry: U.S. Geological Survey Open-File Report 02-337, 12 p. 
62 Surface-Water-Quality Conditions and Relation to Taste-and-Odor Occurrences in the Lake Olathe Watershed, Northeast Kansas, 2000-02 


\section{Supplemental Information}




\section{Surface-Water-Quality Conditions and Relation to Taste-and-Odor Occurrences in the Lake Olathe Watershed, Northeast Kansas, 2000-02}

Table 22. Specifications for the multiparameter YSI 6600 monitor.

[ $\mu \mathrm{S} / \mathrm{cm}$, microsiemens per centimeter at 25 degrees Celsius; ${ }^{\circ} \mathrm{C}$, degrees Celsius; NTU, nephelometric turbidity units; mg/L, milligrams per liter]

\begin{tabular}{llll}
\hline \multicolumn{1}{c}{ Parameter } & \multicolumn{1}{c}{ Sensor type } & \multicolumn{1}{c}{ Range } & Accuracy \\
\hline Specific conductance & four electrode cell with autoranging & 0 to $100,000 \mu \mathrm{S} / \mathrm{cm}$ & \pm 0.5 percent of reading $+1 \mu \mathrm{S} / \mathrm{cm}$ \\
$\mathrm{pH}$ & glass combination electrode & 0 to 14 standard units & \pm 0.2 standard units \\
Water temperature & thermistor & -5 to $45^{\circ} \mathrm{C}$ & $\pm 0.15^{\circ} \mathrm{C}$ \\
Turbidity (6026 sensor) $)$ & optical, $90^{\circ}$ scatter & 0 to $1,000 \mathrm{NTU}{ }^{1}$ & \pm 5 percent of reading \\
Dissolved oxygen & rapid pulse & 0 to $50 \mathrm{mg} / \mathrm{L}$ & 0 to $20 \mathrm{mg} / \mathrm{L}, \pm 0.2 \mathrm{mg} / \mathrm{L} ; 20 \mathrm{to} 50 \mathrm{mg} / \mathrm{L}, \pm 0.6 \mathrm{mg} / \mathrm{L}$ \\
Fluorescence & optical fluorescence with & 0 to $400 \mu \mathrm{g} / \mathrm{L}$ & $\pm 0.1 \mu \mathrm{g} / \mathrm{L}$ \\
$\quad$ mechanical cleaning & & \\
\hline
\end{tabular}

${ }^{1}$ Recent use of the YSI shows that the reporting range can exceed 1,000 NTU. However, the accuracy of the range greater than 1,000 NTU has not been established yet. 
Table 23. Inorganic water-quality constituents, parameter codes, and detection levels for water-quality samples collected from Cedar Creek at Highway 56 and Lake Olathe near Olathe, northeast Kansas, 2000-02.

$[\mu \mathrm{S} / \mathrm{cm}$, microsiemens per centimeter at 25 degrees Celsius; degrees $\mathrm{C}$, degrees Celsius; $\mathrm{mg} / \mathrm{L}$, milligrams per liter; NTU, nephelometric turbidity units; $\mathrm{col} / 100 \mathrm{~mL}$, colonies per 100 milliliters of water; $\mu \mathrm{g} / \mathrm{L}$, micrograms per liter]

\begin{tabular}{|c|c|c|c|c|}
\hline Constituent & $\begin{array}{c}\text { U.S. } \\
\text { Geological } \\
\text { Survey } \\
\text { parameter } \\
\text { code }\end{array}$ & $\begin{array}{l}\text { Units of } \\
\text { measurement }\end{array}$ & Detection level & $\begin{array}{l}\text { Reference for U.S. Geological } \\
\text { Survey analytical method }\end{array}$ \\
\hline Specific conductance, field & 00095 & $\mu \mathrm{S} / \mathrm{cm}$ & 0 to 100,000 & Wilde and Radtke, 1998 \\
\hline Specific conductance, laboratory & 90095 & $\mu \mathrm{S} / \mathrm{cm}$ & 2.6 & Fishman and Friedman, 1989 \\
\hline $\mathrm{pH}$, field & 00400 & standard units & 0 to 14 & Wilde and Radtke, 1998 \\
\hline $\mathrm{pH}$, laboratory & 00403 & standard units & .1 & Fishman and Friedman, 1989 \\
\hline Water temperature & 00010 & degrees $\mathrm{C}$ & -5 to 45 & Wilde and Radtke, 1998 \\
\hline Turbidity & 99872 & NTU & .1 & Fishman and Friedman, 1989 \\
\hline Dissolved oxygen & 00300 & $\mathrm{mg} / \mathrm{L}$ & 0 to 50 & Wilde and Radtke, 1998 \\
\hline Alkalinity, field & 29801 & $\mathrm{mg} / \mathrm{L}$ as $\mathrm{CaCO}_{3}$ & 1 & Fishman and Friedman, 1989 \\
\hline Alkalinity, laboratory & 90410 & $\mathrm{mg} / \mathrm{L}$ as $\mathrm{CaCO}_{3}$ & 1 & Fishman and Friedman, 1989 \\
\hline Dissolved solids & 70300 & $\mathrm{mg} / \mathrm{L}$ & 10 & Fishman and Friedman, 1989 \\
\hline Calcium & 00915 & $\mathrm{mg} / \mathrm{L}$ & .012 & Fishman and Friedman, 1989 \\
\hline Magnesium & 00925 & $\mathrm{mg} / \mathrm{L}$ & .008 & Fishman and Friedman, 1989 \\
\hline Sodium & 00930 & $\mathrm{mg} / \mathrm{L}$ & .09 & Fishman and Friedman, 1989 \\
\hline Potassium & 00935 & $\mathrm{mg} / \mathrm{L}$ & .11 & Fishman and Friedman, 1989 \\
\hline Sulfate & 00945 & $\mathrm{mg} / \mathrm{L}$ & .11 & Fishman and Friedman, 1989 \\
\hline Chloride & 00940 & $\mathrm{mg} / \mathrm{L}$ & .33 & Fishman and Friedman, 1989 \\
\hline Fluoride & 00950 & $\mathrm{mg} / \mathrm{L}$ & .11 & Fishman and Friedman, 1989 \\
\hline Silica & 00955 & $\mathrm{mg} / \mathrm{L}$ & .21 & Fishman and Friedman, 1989 \\
\hline Nitrogen, nitrite & 00613 & $\mathrm{mg} / \mathrm{L}$ & .008 & Fishman and Friedman, 1989 \\
\hline Nitrogen, nitrite plus nitrate & 00631 & $\mathrm{mg} / \mathrm{L}$ & .047 & Fishman and Friedman, 1989 \\
\hline Nitrogen, ammonia & 00608 & $\mathrm{mg} / \mathrm{L}$ & .041 & Fishman and Friedman, 1989 \\
\hline Nitrogen, ammonia plus organic nitrogen & 00625 & $\mathrm{mg} / \mathrm{L}$ & .1 & Fishman and Friedman, 1989 \\
\hline Phosphorus, total & 00665 & $\mathrm{mg} / \mathrm{L}$ & .06 & Patton and Truitt, 1992 \\
\hline Phosphorus, orthophosphate & 00671 & $\mathrm{mg} / \mathrm{L}$ & .018 & Patton and Truitt, 1992 \\
\hline Boron & 01020 & $\mathrm{mg} / \mathrm{L}$ & 13 & Fishman and Friedman, 1989 \\
\hline Iron & 01046 & $\mathrm{mg} / \mathrm{L}$ & 10 & Fishman and Friedman, 1989 \\
\hline Manganese & 01056 & $\mathrm{mg} / \mathrm{L}$ & .1 & Faires, L.M., 1993 \\
\hline E.-coli bacteria & 90902 & $\mathrm{col} / 100 \mathrm{~mL}$ & 1 & $\begin{array}{l}\text { American Public Health } \\
\text { Association and others, } 1985\end{array}$ \\
\hline Fecal coliform bacteria & 31625 & $\mathrm{col} / 100 \mathrm{~mL}$ & 1 & Britton and Greeson, 1989 \\
\hline Enterococci bacteria & 90909 & $\mathrm{col} / 100 \mathrm{~mL}$ & 1 & $\begin{array}{l}\text { American Public Health } \\
\text { Association and others, } 1985\end{array}$ \\
\hline Total suspended solids & 00530 & $\mathrm{mg} / \mathrm{L}$ & 10 & Fishman and Friedman, 1989 \\
\hline Suspended sediment & 80154 & $\mathrm{mg} / \mathrm{L}$ & 10 & Fishman and Friedman, 1989 \\
\hline Atrazine (ELISA) & 34756 & $\mu \mathrm{g} / \mathrm{L}$ & .10 & Zaugg and others, 1995 \\
\hline
\end{tabular}


Table 24. Organic water-quality constituents, parameter codes, and reporting limits for samples collected from Cedar Creek at Highway 56 and Lake Olathe near Olathe, northeast Kansas, 2000-02.

[From Zaugg and others, 1995; $\mu \mathrm{g} / \mathrm{L}$, micrograms per liter; pct, percent]

\begin{tabular}{|c|c|c|c|}
\hline Constituent & $\begin{array}{l}\text { U.S. Geological Survey } \\
\text { parameter code }\end{array}$ & Reporting limit & $\begin{array}{c}\text { Units of } \\
\text { measurement }\end{array}$ \\
\hline 2,6-Diethylaniline & 82660 & 0.006 & $\mu \mathrm{g} / \mathrm{L}$ \\
\hline Acetochlor & 49260 & .006 & $\mu \mathrm{g} / \mathrm{L}$ \\
\hline Alachlor & 46342 & .0045 & $\mu \mathrm{g} / \mathrm{L}$ \\
\hline alpha-HCH & 34253 & .0046 & $\mu \mathrm{g} / \mathrm{L}$ \\
\hline alpha-HCH-d6 (surrogate) & 91065 & .1 & pct \\
\hline Atrazine & 39632 & .007 & $\mu \mathrm{g} / \mathrm{L}$ \\
\hline Azinphos-methyl & 82686 & .05 & $\mu \mathrm{g} / \mathrm{L}$ \\
\hline Benfluralin & 82673 & .01 & $\mu \mathrm{g} / \mathrm{L}$ \\
\hline Butylate & 04028 & .002 & $\mu \mathrm{g} / \mathrm{L}$ \\
\hline Carbaryl & 82680 & .041 & $\mu \mathrm{g} / \mathrm{L}$ \\
\hline Carbofuran & 82674 & .02 & $\mu \mathrm{g} / \mathrm{L}$ \\
\hline Chlorpyrifos & 38933 & .005 & $\mu \mathrm{g} / \mathrm{L}$ \\
\hline cis-Permethrin & 82687 & .006 & $\mu \mathrm{g} / \mathrm{L}$ \\
\hline Cyanazine & 04041 & .018 & $\mu \mathrm{g} / \mathrm{L}$ \\
\hline Dacthal & 82682 & .003 & $\mu \mathrm{g} / \mathrm{L}$ \\
\hline Deethylatrazine & 04040 & .006 & $\mu \mathrm{g} / \mathrm{L}$ \\
\hline Diazinon & 39572 & .005 & $\mu \mathrm{g} / \mathrm{L}$ \\
\hline Diazinon-d10 (surrogate) & 91063 & .1 & pct \\
\hline Dieldrin & 39381 & .0048 & $\mu \mathrm{g} / \mathrm{L}$ \\
\hline Disulfoton & 82677 & .021 & $\mu \mathrm{g} / \mathrm{L}$ \\
\hline ЕРТC & 82668 & .002 & $\mu \mathrm{g} / \mathrm{L}$ \\
\hline Ethalfluralin & 82663 & .009 & $\mu \mathrm{g} / \mathrm{L}$ \\
\hline Ethoprophos & 82672 & .005 & $\mu \mathrm{g} / \mathrm{L}$ \\
\hline Fonofos & 04095 & .0027 & $\mu \mathrm{g} / \mathrm{L}$ \\
\hline Lindane & 39341 & .004 & $\mu \mathrm{g} / \mathrm{L}$ \\
\hline Linuron & 82666 & .035 & $\mu \mathrm{g} / \mathrm{L}$ \\
\hline Malathion & 39532 & .027 & $\mu \mathrm{g} / \mathrm{L}$ \\
\hline Metolachlor & 39415 & .013 & $\mu \mathrm{g} / \mathrm{L}$ \\
\hline Metribuzin & 82630 & .006 & $\mu \mathrm{g} / \mathrm{L}$ \\
\hline Molinate & 82671 & .0016 & $\mu \mathrm{g} / \mathrm{L}$ \\
\hline Napropamide & 82684 & .007 & $\mu \mathrm{g} / \mathrm{L}$ \\
\hline $\mathrm{p}, \mathrm{p}^{\prime}-\mathrm{DDE}$ & 34653 & .0025 & $\mu \mathrm{g} / \mathrm{L}$ \\
\hline Parathion & 39542 & .01 & $\mu \mathrm{g} / \mathrm{L}$ \\
\hline Parathion-methyl & 82667 & .006 & $\mu \mathrm{g} / \mathrm{L}$ \\
\hline Pebulate & 82669 & .0041 & $\mu \mathrm{g} / \mathrm{L}$ \\
\hline Pendimethalin & 82683 & .022 & $\mu \mathrm{g} / \mathrm{L}$ \\
\hline Phorate & 82664 & .011 & $\mu \mathrm{g} / \mathrm{L}$ \\
\hline
\end{tabular}


Table 24. Organic water-quality constituents, parameter codes, and reporting limits for samples collected from Cedar Creek at Highway 56 and Lake Olathe near Olathe, northeast Kansas, 2000-02.-Continued

[From Zaugg and others, 1995; $\mu \mathrm{g} / \mathrm{L}$, micrograms per liter; pct, percent]

\begin{tabular}{lccc}
\hline \multicolumn{1}{c}{ Constituent } & $\begin{array}{c}\text { U.S. Geological Survey } \\
\text { parameter code }\end{array}$ & Reporting limit & $\begin{array}{c}\text { Units of } \\
\text { measurement }\end{array}$ \\
\hline Prometon & 04037 & 0.015 & $\mu \mathrm{g} / \mathrm{L}$ \\
Propachlor & 04024 & .01 & $\mu \mathrm{g} / \mathrm{L}$ \\
Propanil & 82679 & .011 & $\mu \mathrm{g} / \mathrm{L}$ \\
Propargite & 82685 & .023 & $\mu \mathrm{g} / \mathrm{L}$ \\
Propyzamide & 82676 & .0041 & $\mu \mathrm{g} / \mathrm{L}$ \\
& & & \\
Simazine & 04035 & .005 & $\mu \mathrm{g} / \mathrm{L}$ \\
Tebuthiuron & 82670 & .016 & $\mu \mathrm{g} / \mathrm{L}$ \\
Terbacil & 82665 & .034 & $\mu \mathrm{g} / \mathrm{L}$ \\
Terbufos & 82675 & .017 & $\mu \mathrm{g} / \mathrm{L}$ \\
Thiobencarb & 82681 & .0048 & $\mu \mathrm{g} / \mathrm{L}$ \\
& & & \\
Triallate & 82678 & .0023 & $\mu \mathrm{g} / \mathrm{L}$ \\
Trifluralin & 82661 & .009 & $\mu \mathrm{g} / \mathrm{L}$ \\
\hline
\end{tabular}


Table 25. Results of equipment and rinse blank analysis of water-quality samples collected from Lake Olathe near Olathe, northeast Kansas, 2000-02.

$[\mu \mathrm{S} / \mathrm{cm}$, microsiemen per centimeter at 25 degrees Celsius; $\mathrm{mg} / \mathrm{L}$, milligrams per liter; $\mu \mathrm{g} / \mathrm{L}$, micrograms per liter; E, estimated; <, less than; --, not applicable]

\begin{tabular}{|c|c|c|c|c|c|c|c|}
\hline \multirow[b]{2}{*}{ Constituent (unit of measurement) } & \multicolumn{7}{|c|}{ Sample type and date (month/day/year) } \\
\hline & $\begin{array}{l}\text { Equipment } \\
\text { blank } \\
(12 / 5 / 2000)\end{array}$ & $\begin{array}{l}\text { Rinse blank } \\
(12 / 7 / 2000)\end{array}$ & $\begin{array}{l}\text { Rinse blank } \\
(12 / 8 / 2000)\end{array}$ & $\begin{array}{l}\text { Rinse blank } \\
(7 / 24 / 2002)\end{array}$ & $\begin{array}{l}\text { Equipment } \\
\text { blank } \\
(10 / 22 / 2001)\end{array}$ & $\begin{array}{l}\text { Equipment } \\
\text { blank } \\
(7 / 18 / 2002)\end{array}$ & $\begin{array}{l}\text { Equipment } \\
\text { blank } \\
(7 / 23 / 2002)\end{array}$ \\
\hline Specific conductance $(\mu \mathrm{S} / \mathrm{cm})$ & E1.8 & E2.0 & E1.9 & -- & 4.0 & 3.5 & 4.2 \\
\hline pH (standard units) & 7.3 & 7.5 & 7.3 & -- & 6.0 & 8.2 & 8.0 \\
\hline Alkalinity $\left(\mathrm{mg} / \mathrm{L}\right.$ as $\left.\mathrm{CaCO}_{3}\right)$ & 1.9 & 1.9 & 1.7 & -- & 1.1 & 1.8 & 1.8 \\
\hline Calcium $(\mathrm{mg} / \mathrm{L})$ & $<.01$ & E.01 & $<.01$ & -- & .03 & .04 & .26 \\
\hline Magnesium (mg/L) & $<.01$ & $<.01$ & $<.01$ & -- & $<.01$ & $\mathrm{E}<.01$ & .02 \\
\hline Sodium (mg/L) & .04 & E.03 & E.05 & -- & E.05 & $<.09$ & E.06 \\
\hline Chloride (mg/L) & $<.08$ & $<.08$ & $<.08$ & -- & .55 & $<.30$ & $<.30$ \\
\hline Fluoride (mg/L) & $<.16$ & $<.16$ & $<.16$ & -- & $<.10$ & E.06 & $<.10$ \\
\hline $\begin{array}{l}\text { Ammonia plus organic nitrogen, as } \\
\text { nitrogen }(\mathrm{mg} / \mathrm{L})\end{array}$ & $<.08$ & $<.08$ & E.05 & -- & $<.10$ & $<.10$ & E.06 \\
\hline $\begin{array}{l}\text { Ammonia plus dissolved organic nitro- } \\
\text { gen, as nitrogen }(\mathrm{mg} / \mathrm{L})\end{array}$ & $<.10$ & $<.10$ & $<.10$ & -- & $<.10$ & $<.10$ & E.05 \\
\hline Boron $(\mu \mathrm{g} / \mathrm{L})$ & 22 & 19 & E13 & -- & E11 & $<13$ & $<13$ \\
\hline Manganese $(\mu \mathrm{g} / \mathrm{L})$ & -- & -- & E.08 & -- & E.07 & E.05 & .21 \\
\hline 2,6-Diethylaniline $(\mu \mathrm{g} / \mathrm{L})$ & -- & -- & -- & $<0.1$ & -- & -- & -- \\
\hline $\begin{array}{l}\text { 2-Chloro-4-isopropylamino-6-amino- } \\
\text { s-triazine }(\mu \mathrm{g} / \mathrm{L})\end{array}$ & -- & -- & -- & $<.006$ & -- & -- & -- \\
\hline Acetochlor $(\mu \mathrm{g} / \mathrm{L})$ & -- & -- & -- & $<.006$ & -- & -- & -- \\
\hline Alachlor $(\mu \mathrm{g} / \mathrm{L})$ & -- & -- & -- & $<.006$ & -- & -- & -- \\
\hline Azinphos-methyl $(\mu \mathrm{g} / \mathrm{L})$ & -- & -- & -- & $<.007$ & -- & -- & -- \\
\hline Benfluralin $(\mu \mathrm{g} / \mathrm{L})$ & -- & -- & -- & $<.05$ & -- & -- & -- \\
\hline Butylate $(\mu \mathrm{g} / \mathrm{L})$ & -- & -- & -- & $<.01$ & -- & -- & -- \\
\hline Carbaryl ( $\mu \mathrm{g} / \mathrm{L})$ & -- & -- & -- & $<.002$ & -- & -- & -- \\
\hline Carbofuran $(\mu \mathrm{g} / \mathrm{L})$ & -- & -- & -- & $<.041$ & -- & -- & -- \\
\hline Chlorpyrifos $(\mu \mathrm{g} / \mathrm{L})$ & -- & -- & -- & $<.02$ & -- & -- & -- \\
\hline cis-Permethrin $(\mu \mathrm{g} / \mathrm{L})$ & -- & -- & -- & $<.005$ & -- & -- & -- \\
\hline Cyanazine $(\mu \mathrm{g} / \mathrm{L})$ & -- & -- & -- & $<.006$ & -- & -- & -- \\
\hline DCPA $(\mu \mathrm{g} / \mathrm{L})$ & -- & -- & -- & $<.018$ & -- & -- & -- \\
\hline Diazinon $(\mu \mathrm{g} / \mathrm{L})$ & -- & -- & -- & $<.003$ & -- & -- & -- \\
\hline Disulfoton $(\mu \mathrm{g} / \mathrm{L})$ & -- & -- & -- & $<.005$ & -- & -- & -- \\
\hline EPTC $(\mu \mathrm{g} / \mathrm{L})$ & -- & -- & -- & $<.021$ & -- & -- & -- \\
\hline Ethalfluralin $(\mu \mathrm{g} / \mathrm{L})$ & -- & -- & -- & $<.002$ & -- & -- & -- \\
\hline Ethoprop $(\mu \mathrm{g} / \mathrm{L})$ & -- & -- & -- & $<.009$ & -- & -- & -- \\
\hline Fonofos $(\mu \mathrm{g} / \mathrm{L})$ & -- & -- & -- & $<.005$ & -- & -- & -- \\
\hline Lindane $(\mu \mathrm{g} / \mathrm{L})$ & -- & -- & -- & $<.003$ & -- & -- & -- \\
\hline Linuron $(\mu \mathrm{g} / \mathrm{L})$ & -- & -- & -- & $<.004$ & -- & -- & -- \\
\hline
\end{tabular}


Table 25. Results of equipment and rinse blank analysis of water-quality samples collected from Lake Olathe near Olathe, northeast Kansas, 2000-02.-Continued

$[\mu \mathrm{S} / \mathrm{cm}$, microsiemen per centimeter at 25 degrees Celsius; mg/L, milligrams per liter; $\mu \mathrm{g} / \mathrm{L}$, micrograms per liter; E, estimated; <, less than; --, not applicable]

\begin{tabular}{|c|c|c|c|c|c|c|c|}
\hline \multirow[b]{2}{*}{ Constituent (unit of measurement) } & \multicolumn{7}{|c|}{ Sample type and date (month/day/year) } \\
\hline & $\begin{array}{l}\text { Equipment } \\
\text { blank } \\
(12 / 5 / 2000)\end{array}$ & $\begin{array}{l}\text { Rinse blank } \\
(12 / 7 / 2000)\end{array}$ & $\begin{array}{c}\text { Rinse blank } \\
(12 / 8 / 2000)\end{array}$ & $\begin{array}{c}\text { Rinse blank } \\
(7 / 24 / 2002)\end{array}$ & $\begin{array}{c}\text { Equipment } \\
\text { blank } \\
(10 / 22 / 2001)\end{array}$ & $\begin{array}{c}\text { Equipment } \\
\text { blank } \\
(7 / 18 / 2002)\end{array}$ & $\begin{array}{c}\text { Equipment } \\
\text { blank } \\
(7 / 23 / 2002)\end{array}$ \\
\hline Malathion $(\mu \mathrm{g} / \mathrm{L})$ & -- & -- & -- & $<0.035$ & -- & -- & -- \\
\hline Methyl parathion $(\mu \mathrm{g} / \mathrm{L})$ & -- & -- & -- & $<.027$ & -- & -- & -- \\
\hline Metolachlor $(\mu \mathrm{g} / \mathrm{L})$ & -- & -- & -- & $<.006$ & -- & -- & -- \\
\hline Metribuzin $(\mu \mathrm{g} / \mathrm{L})$ & -- & -- & -- & $<.013$ & -- & -- & -- \\
\hline Molinate $(\mu \mathrm{g} / \mathrm{L})$ & -- & -- & -- & $<.006$ & -- & -- & -- \\
\hline Napropamide $(\mu \mathrm{g} / \mathrm{L})$ & -- & -- & -- & $<.002$ & -- & -- & -- \\
\hline $\mathrm{p}, \mathrm{p}$-DDE $(\mu \mathrm{g} / \mathrm{L})$ & -- & -- & -- & $<.007$ & -- & -- & -- \\
\hline Parathion $(\mu \mathrm{g} / \mathrm{L})$ & -- & -- & -- & $<.002$ & -- & -- & -- \\
\hline Pebulate $(\mu \mathrm{g} / \mathrm{L})$ & -- & -- & -- & $<.01$ & -- & -- & -- \\
\hline Pendimethalin $(\mu \mathrm{g} / \mathrm{L})$ & -- & -- & -- & $<.004$ & -- & -- & -- \\
\hline Phorate $(\mu \mathrm{g} / \mathrm{L})$ & -- & -- & -- & $<.02$ & -- & -- & -- \\
\hline Prometon $(\mu \mathrm{g} / \mathrm{L})$ & -- & -- & -- & $<.01$ & -- & -- & -- \\
\hline Pronamide $(\mu \mathrm{g} / \mathrm{L})$ & -- & -- & -- & $<.02$ & -- & -- & -- \\
\hline Propachlor $(\mu \mathrm{g} / \mathrm{L})$ & -- & -- & -- & $<.004$ & -- & -- & -- \\
\hline Propanil $(\mu \mathrm{g} / \mathrm{L})$ & -- & -- & -- & $<.01$ & -- & -- & -- \\
\hline Propargite $(\mu \mathrm{g} / \mathrm{L})$ & -- & -- & -- & $<.01$ & -- & -- & -- \\
\hline Simazine $(\mu \mathrm{g} / \mathrm{L})$ & -- & -- & -- & $<.02$ & -- & -- & -- \\
\hline Tebuthiuron $(\mu \mathrm{g} / \mathrm{L})$ & -- & -- & -- & $<.005$ & -- & -- & -- \\
\hline Terbacil $(\mu \mathrm{g} / \mathrm{L})$ & -- & -- & -- & $<.016$ & -- & -- & -- \\
\hline Terbufos $(\mu \mathrm{g} / \mathrm{L})$ & -- & -- & -- & $<.034$ & -- & -- & -- \\
\hline Thiobencarb $(\mu \mathrm{g} / \mathrm{L})$ & -- & -- & -- & $<.017$ & -- & -- & -- \\
\hline Triallate $(\mu \mathrm{g} / \mathrm{L})$ & -- & -- & -- & $<.005$ & -- & -- & -- \\
\hline Triazine screen $(\mu \mathrm{g} / \mathrm{L})$ & -- & -- & -- & $<.002$ & -- & -- & -- \\
\hline Trifluralin $(\mu \mathrm{g} / \mathrm{L})$ & -- & -- & -- & $<.009$ & -- & -- & -- \\
\hline
\end{tabular}


70 Surface-Water-Quality Conditions and Relation to Taste-and-Odor Occurrences in the Lake Olathe Watershed, Northeast Kansas, 2000-02

Table 26. Results of replicate sample analysis for water-quality samples collected from Lake Olathe near dam (site 2), northeast Kansas, 2001-02.

[mg/L, milligrams per liter; $\mu \mathrm{g} / \mathrm{L}$, micrograms per liter; ng/L, nanograms per liter; <, less than; --, not calculated; E, estimated]

\begin{tabular}{|c|c|c|c|}
\hline Description (unit of measurement) & $\begin{array}{c}\text { Original sample } \\
\text { (Lake Olathe near } \\
\text { dam) }\end{array}$ & $\begin{array}{l}\text { Replicate sample } \\
\text { (Lake Olathe near } \\
\text { dam) }\end{array}$ & $\begin{array}{l}\text { Relative } \\
\text { percentage } \\
\text { difference }\end{array}$ \\
\hline Date (month/day/year) & $4 / 18 / 2001$ & $4 / 18 / 2001$ & \\
\hline Time (24-hour) & 1020 & 1025 & \\
\hline Ammonia, as nitrogen $(\mathrm{mg} / \mathrm{L})$ & 0.09 & 0.09 & 0 \\
\hline Ammonia plus dissolved organic nitrogen, as nitrogen (mg/L) & .51 & .54 & -5.71 \\
\hline Ammonia plus organic nitrogen, as nitrogen (mg/L) & .81 & .72 & 11.76 \\
\hline Nitrite plus nitrate, as nitrogen (mg/L) & 2.0 & 2.0 & 0 \\
\hline Nitrite, as nitrogen (mg/L) & .04 & .04 & 0 \\
\hline Phosphorus, dissolved, as phosphorus (mg/L) & $<.06$ & $<.06$ & -- \\
\hline Phosphate, ortho, as phosphorus (mg/L) & $<.02$ & $<.02$ & -- \\
\hline Phosphorus, total, as phosphorus (mg/L) & E.03 & $<.06$ & -- \\
\hline Date (month/day/year) & $5 / 17 / 2001$ & $5 / 17 / 2001$ & \\
\hline Time (24-hour) & 1000 & 1005 & \\
\hline Ammonia, as nitrogen $(\mathrm{mg} / \mathrm{L})$ & $<.04$ & $<.04$ & -- \\
\hline Ammonia plus dissolved organic nitrogen, as nitrogen (mg/L) & .39 & .41 & -5.0 \\
\hline Ammonia plus organic nitrogen, as nitrogen (mg/L) & .56 & .58 & -3.51 \\
\hline Nitrite plus nitrate, as nitrogen (mg/L) & 1.2 & 1.2 & 0 \\
\hline Nitrite, as nitrogen (mg/L) & .04 & .04 & 0 \\
\hline Phosphorus, dissolved, as phosphorus (mg/L) & $<.06$ & $<.06$ & -- \\
\hline Phosphate, ortho, as phosphorus (mg/L) & $<.02$ & $<.02$ & -- \\
\hline Phosphorus, total, as phosphorus (mg/L) & $<.06$ & $<.06$ & -- \\
\hline Date (month/day/year) & $6 / 4 / 2002$ & $6 / 4 / 2002$ & \\
\hline Time (24-hour) & 1100 & 1105 & -- \\
\hline Suspended sediment concentration (mg/L) & 5.8 & 2.7 & 72.94 \\
\hline Chlorophyll- $a$, HPLC ( $\mu \mathrm{g} / \mathrm{L})$ & 14 & 18 & -25 \\
\hline Chlorophyll- $b$, HPLC ( $\mu \mathrm{g} / \mathrm{L})$ & 2 & 2 & 0 \\
\hline Phytoplankton biomass, ash weight (mg/L) & 2,470 & 2,580 & -4.35 \\
\hline Phytoplankton biomass, dry weight (mg/L) & 2,520 & 2,620 & -3.89 \\
\hline 2-Methylisoborneol (ng/L) & $<5$ & $<5$ & -- \\
\hline Geosmin, (ng/L) & $<5$ & $<5$ & -- \\
\hline Date (month/day/year) & $6 / 27 / 2001$ & $6 / 27 / 2001$ & \\
\hline Time (24-hour) & 1020 & 1025 & -- \\
\hline Ammonia, as nitrogen $(\mathrm{mg} / \mathrm{L})$ & $<.04$ & E.02 & -- \\
\hline Ammonia plus dissolved organic nitrogen, as nitrogen (mg/L) & .39 & .42 & -7.41 \\
\hline Ammonia plus organic nitrogen, as nitrogen (mg/L) & .72 & 1.0 & -32.56 \\
\hline Nitrite plus nitrate, as nitrogen (mg/L) & .96 & .94 & 2.1 \\
\hline Nitrite, as nitrogen (mg/L) & .06 & .06 & 0 \\
\hline Phosphorus, dissolved, as phosphorus (mg/L) & $<.06$ & $<.06$ & -- \\
\hline
\end{tabular}


Table 26. Results of replicate sample analysis for water-quality samples collected from Lake Olathe near dam (site 2), northeast Kansas, 2001-02. - Continued

[mg/L, milligrams per liter; $\mu \mathrm{g} / \mathrm{L}$, micrograms per liter; ng/L, nanograms per liter; <, less than; --, not calculated; E, estimated]

\begin{tabular}{|c|c|c|c|}
\hline Description (unit of measurement) & $\begin{array}{c}\text { Original sample } \\
\text { (Lake Olathe near } \\
\text { dam) }\end{array}$ & $\begin{array}{l}\text { Replicate sample } \\
\text { (Lake Olathe near } \\
\text { dam) }\end{array}$ & $\begin{array}{c}\text { Relative } \\
\text { percentage } \\
\text { difference }\end{array}$ \\
\hline & 6/27/2001 & 6/27/2001 & \\
\hline Phosphate, ortho, as phosphorus (mg/L) & $<0.02$ & $<0.02$ & -- \\
\hline Phosphorus, total, as phosphorus (mg/L) & E.04 & E.06 & -40 \\
\hline Date (month/day/year) & $8 / 14 / 2001$ & $8 / 14 / 2001$ & \\
\hline Time (24-hour) & 945 & 950 & -- \\
\hline Ammonia, as nitrogen $(\mathrm{mg} / \mathrm{L})$ & E.03 & E.02 & 40 \\
\hline Ammonia plus dissolved organic nitrogen, as nitrogen $(\mathrm{mg} / \mathrm{L})$ & .36 & .34 & 5.7 \\
\hline Ammonia plus organic nitrogen, as nitrogen (mg/L) & .81 & .77 & 5.1 \\
\hline Nitrite plus nitrate, as nitrogen (mg/L) & E.02 & E.03 & -40 \\
\hline Nitrite, as nitrogen $(\mathrm{mg} / \mathrm{L})$ & $<.006$ & $<.006$ & -- \\
\hline Phosphorus, dissolved, as phosphorus (mg/L) & $<.06$ & $<.06$ & -- \\
\hline Phosphate, ortho, as phosphorus (mg/L) & $<.02$ & $<.02$ & -- \\
\hline Phosphorus, total, as phosphorus (mg/L) & E.04 & E.03 & 29 \\
\hline Date (month/day/year) & $8 / 15 / 2001$ & $8 / 15 / 2001$ & \\
\hline Time (24-hour) & 900 & 905 & \\
\hline Ammonia, as nitrogen $(\mathrm{mg} / \mathrm{L})$ & .40 & .40 & 0 \\
\hline Ammonia plus dissolved organic nitrogen, as nitrogen $(\mathrm{mg} / \mathrm{L})$ & .77 & .83 & -7.5 \\
\hline Ammonia plus organic nitrogen, as nitrogen (mg/L) & E.03 & E.03 & 0 \\
\hline Nitrite plus nitrate, as nitrogen (mg/L) & $<.05$ & $<.05$ & -- \\
\hline Nitrite, as nitrogen $(\mathrm{mg} / \mathrm{L})$ & $<.006$ & $<.006$ & -- \\
\hline Phosphorus, dissolved, as phosphorus (mg/L) & $<.02$ & $<.02$ & -- \\
\hline Phosphate, ortho, as phosphorus (mg/L) & $<.06$ & $<.06$ & -- \\
\hline Phosphorus, total, as phosphorus (mg/L) & E.05 & E.05 & 0 \\
\hline Date (month/day/year) & $6 / 18 / 2002$ & $6 / 18 / 2002$ & \\
\hline Time (24-hour) & 1345 & 1350 & -- \\
\hline Total organic carbon $(\mathrm{mg} / \mathrm{L})$ & 6.4 & 6.6 & -3.08 \\
\hline Chlorophyll- $a$, chromatographic $(\mu \mathrm{g} / \mathrm{L})$ & 22 & 22 & 0 \\
\hline Geosmin, (ng/L) & $<5$ & $<5$ & -- \\
\hline 2-Methylisoborneol (ng/L) & $<5$ & $<5$ & -- \\
\hline
\end{tabular}


72 Surface-Water-Quality Conditions and Relation to Taste-and-Odor Occurrences in the Lake Olathe Watershed, Northeast Kansas, 2000-02

Table 27. Phytoplankton taxa, biovolume, and relative percentage abundance in water from Cedar Creek at Highway 56, northeast Kansas, 2000-02.

$\left[\mu \mathrm{m}^{3} / \mathrm{mL}\right.$, cubic micrometers per milliliter of water]

\begin{tabular}{|c|c|c|c|}
\hline $\begin{array}{c}\text { Date } \\
\text { (month/day/year) }\end{array}$ & Taxa & $\begin{array}{c}\text { Biovolume, } \\
\left(\mu \mathrm{m}^{3} / \mathrm{mL}\right)\end{array}$ & $\begin{array}{c}\text { Relative } \\
\text { percentage } \\
\text { abundance }\end{array}$ \\
\hline \multirow[t]{37}{*}{$6 / 19 / 2000$} & Bacillariophyta & & \\
\hline & Amphora ovalis & 6,170 & 1.11 \\
\hline & Cyclotella spp. & 47,600 & 8.52 \\
\hline & Denticula spp. & 2,280 & .41 \\
\hline & Diploneis spp. & 2,640 & .47 \\
\hline & Fragilaria spp. & 1,220 & .22 \\
\hline & Gyrosigma scalproides & 4,850 & .87 \\
\hline & Meridion circulare & 4,410 & .79 \\
\hline & Navicula tripunctata & 2,230 & .40 \\
\hline & Navicula trivialis & 4,570 & .82 \\
\hline & Nitzschia acicularis & 3,200 & .57 \\
\hline & Nitzschia spp. & 14,600 & 2.61 \\
\hline & Nitzschia levidensis & 2,280 & .41 \\
\hline & Nitzschia linearis & 6,400 & 1.15 \\
\hline & Nitzschia palea & 4,570 & .82 \\
\hline & Planothidium lanceolatum & 10,600 & 1.89 \\
\hline & Rhoicosphenia curvata & 24,200 & 4.34 \\
\hline & Chlorophyta & & \\
\hline & Chlamydomonas globosa & 5,290 & .95 \\
\hline & Chlorella vulgaris & 89,900 & 16.1 \\
\hline & Micrasterias radiata & 1,140 & .21 \\
\hline & Scenedesmus bijuga & 16,900 & 3.03 \\
\hline & Ulothrix subtilissima & 130,000 & 23.3 \\
\hline & Chrysophyta & & \\
\hline & Mallomonas acaroids & 44,100 & 7.89 \\
\hline & Mallomonas apochromatica & 600 & .11 \\
\hline & Cyanophyta & & \\
\hline & Chroococcus turgidis & 800 & .14 \\
\hline & Euglenophyta & & \\
\hline & Euglena spp. & 8,810 & 1.58 \\
\hline & Trachelomonas laucustris & 2,630 & .47 \\
\hline & Trachelomonas pulchella & 35,300 & 6.31 \\
\hline & Trachelomonas spp. & 24,700 & 4.42 \\
\hline & Pyrrophyta & & \\
\hline & Glenodinium sp. & 28,600 & 5.12 \\
\hline & Gymnodinium sp. & 26,400 & 4.74 \\
\hline & Peridinium spp. & 1,140 & .20 \\
\hline \multirow[t]{6}{*}{$6 / 20 / 2000$} & Bacillariophyta & & \\
\hline & Denticula spp. & 11,400 & 1.12 \\
\hline & Fragilaria spp. & 3,040 & .30 \\
\hline & Gomphonema acuminatum & 14,300 & 1.40 \\
\hline & Gomphonema truncatum & 2,400 & .23 \\
\hline & Meridion circulare & 14,300 & 1.40 \\
\hline
\end{tabular}


Table 27. Phytoplankton taxa, biovolume, and relative percentage abundance in water from Cedar Creek at Highway 56, northeast Kansas, 2000-02. - Continued

[ $\mu \mathrm{m}^{3} / \mathrm{mL}$, cubic micrometers per milliliter of water]

\begin{tabular}{|c|c|c|c|}
\hline $\begin{array}{c}\text { Date } \\
\text { (month/day/year) }\end{array}$ & Taxa & $\begin{array}{c}\text { Biovolume, } \\
\left(\mu \mathrm{m}^{3} / \mathrm{mL}\right)\end{array}$ & $\begin{array}{c}\text { Relative } \\
\text { percentage } \\
\text { abundance }\end{array}$ \\
\hline \multirow[t]{27}{*}{$6 / 20 / 2000$} & Bacillariophyta-Continued & & \\
\hline & Navicula trivialis & 35,300 & 3.45 \\
\hline & Nitzschia spp. & 31,400 & 3.08 \\
\hline & Nitzschia levidensis & 17,600 & 1.73 \\
\hline & Nitzschia linearis & 37,500 & 3.67 \\
\hline & Planothidium lanceolatum & 720 & .07 \\
\hline & Rhoicosphenia curvata & 141,000 & 13.8 \\
\hline & Surirella ovata & 10,300 & 1.01 \\
\hline & Synedra spp. & 360 & .03 \\
\hline & Chlorophyta & & \\
\hline & Chlorella ellipsoidea & 66,100 & 6.47 \\
\hline & Chlorella vulgaris & 31,700 & 3.11 \\
\hline & Cosmarium spp. & 33,100 & 3.24 \\
\hline & Scenedesmus bijuga & 42,300 & 4.14 \\
\hline & Staurastrum spp. & 247,000 & 24.2 \\
\hline & Ulothrix subtilissima & 51,400 & 5.03 \\
\hline & Cryptophyta & & \\
\hline & Cryptomonas spp. & 800 & .08 \\
\hline & Cyanophyta & & \\
\hline & Aphanocapsa spp. & 168,000 & 16.4 \\
\hline & Oscillatoria sp. & 360 & .03 \\
\hline & Euglenophyta & & \\
\hline & Euglena spp. & 14,300 & 1.40 \\
\hline & Phacus spp. & 17,600 & 1.73 \\
\hline & Trachelomonas laucustris & 460 & .04 \\
\hline & Trachelomonas pulchella & 14,300 & 1.40 \\
\hline & Trachelomonas spp. & 14,300 & 1.40 \\
\hline \multirow[t]{17}{*}{$7 / 19 / 2000$} & Bacillariophyta & & \\
\hline & Achnanthes deflexa & 685 & .19 \\
\hline & Achnanthidium minutissima & 8,640 & 2.43 \\
\hline & Aulacoseira granulata & 25,100 & 7.08 \\
\hline & Cocconeis placentula & 2,630 & .74 \\
\hline & Craticula cuspidata & 440 & .12 \\
\hline & Cyclotella spp. & 6,340 & 1.79 \\
\hline & Frustulia vulgaris & 10,600 & 2.98 \\
\hline & Gomphoneis herculeana & 5,290 & 1.49 \\
\hline & Gomphonema parvulum & 5,290 & 1.49 \\
\hline & Mastigloia cf smithii & 6,170 & 1.74 \\
\hline & Navicula spp. & 44,100 & 12.4 \\
\hline & Navicula symmetrica & 12,300 & 3.48 \\
\hline & Navicula tripunctata & 4,570 & 1.29 \\
\hline & Nitzschia clausii & 2,570 & .72 \\
\hline & Nitzschia spp. & 96,900 & 27.3 \\
\hline & Nitzschia levidensis & 7,050 & 1.99 \\
\hline
\end{tabular}


74 Surface-Water-Quality Conditions and Relation to Taste-and-Odor Occurrences in the Lake Olathe Watershed, Northeast Kansas, 2000-02

Table 27. Phytoplankton taxa, biovolume, and relative percentage abundance in water from Cedar Creek at Highway 56, northeast Kansas, 2000-02.-Continued

$\left[\mu \mathrm{m}^{3} / \mathrm{mL}\right.$, cubic micrometers per milliliter of water]

\begin{tabular}{|c|c|c|c|}
\hline $\begin{array}{c}\text { Date } \\
\text { (month/day/year) }\end{array}$ & Taxa & $\begin{array}{c}\text { Biovolume, } \\
\left(\mu \mathrm{m}^{3} / \mathrm{mL}\right)\end{array}$ & $\begin{array}{c}\text { Relative } \\
\text { percentage } \\
\text { abundance }\end{array}$ \\
\hline \multirow[t]{23}{*}{$7 / 19 / 2000$} & Bacillariophyta-Continued & & \\
\hline & Nitzschia linearis & 9,710 & 2.74 \\
\hline & Nitzschia palea & 10,600 & 2.98 \\
\hline & Nitzschia sigma & 5,940 & 1.67 \\
\hline & Planothidium lanceolatum & 3,170 & .89 \\
\hline & Rhoicosphenia curvata & 5,710 & 1.61 \\
\hline & Surirella ovata & 3,170 & .89 \\
\hline & Chlorophyta & & \\
\hline & Cosmarium spp. & 4,410 & 1.24 \\
\hline & Microspora spp. & 4,100 & 1.16 \\
\hline & Mougeotia sp. & 30,800 & 8.70 \\
\hline & Oedogonium sp. & 10,600 & 2.98 \\
\hline & Oocystis borgei & 10,600 & 2.98 \\
\hline & Cyanophyta & & \\
\hline & Chroococcus spp. & 1,230 & .35 \\
\hline & Merismopedia sp. & 1,410 & .40 \\
\hline & Euglenophyta & & \\
\hline & Phacus spp. & 3,520 & .99 \\
\hline & Trachelomonas spp. & 8,810 & 2.48 \\
\hline & Pyrrophyta & & \\
\hline & Glenodinium sp. & 52 & .01 \\
\hline & Gymnodinium sp. & 1,320 & .37 \\
\hline & Peridinium spp. & 881 & .25 \\
\hline \multirow[t]{16}{*}{$10 / 24 / 2000$} & Bacillariophyta & & \\
\hline & Fragilaria capucina & 2,820 & .33 \\
\hline & Gyrosigma sp. & 965 & .11 \\
\hline & Synedra delicattissima & 72 & .01 \\
\hline & Synedra ulna & 319 & .04 \\
\hline & Chlorophyta & & \\
\hline & Chlamydomonas globosa & 416,000 & 48.3 \\
\hline & Cyanophyta & & \\
\hline & Anabaena spp. & 21 & 0 \\
\hline & Euglenophyta & & \\
\hline & Euglena acus & 2,410 & .28 \\
\hline & Trachelomonas crebea & 6,030 & .70 \\
\hline & Trachelomonas hispida & 489 & .06 \\
\hline & Trachelomonas pulcherrima & 85,100 & 9.86 \\
\hline & Trachelomonas volvocina & 162,000 & 18.8 \\
\hline & Trachelomonas spp. & 186,000 & 21.5 \\
\hline \multirow[t]{4}{*}{$3 / 21 / 2001$} & Bacillariophyta & & \\
\hline & Cocconeis placentula & 783 & .70 \\
\hline & Cyclotella spp. & 751 & .67 \\
\hline & Cymbella sp. & 1,140 & 1.02 \\
\hline
\end{tabular}


Table 27. Phytoplankton taxa, biovolume, and relative percentage abundance in water from Cedar Creek at Highway 56, northeast Kansas, 2000-02. - Continued

[ $\mu \mathrm{m}^{3} / \mathrm{mL}$, cubic micrometers per milliliter of water]

\begin{tabular}{|c|c|c|c|}
\hline $\begin{array}{c}\text { Date } \\
\text { (month/day/year) }\end{array}$ & Taxa & $\begin{array}{l}\text { Biovolume, } \\
\left(\mu \mathrm{m}^{3} / \mathrm{mL}\right)\end{array}$ & $\begin{array}{c}\text { Relative } \\
\text { percentage } \\
\text { abundance }\end{array}$ \\
\hline \multirow[t]{19}{*}{$3 / 21 / 2001$} & Bacillariophyta-Continued & & \\
\hline & Diploneis spp. & 44 & 0.04 \\
\hline & Gyrosigma sp. & 1,560 & 1.40 \\
\hline & Navicula spp. & 1,480 & 1.33 \\
\hline & Pinnularia sp. & 771 & 69 \\
\hline & Stauroneis sp. & 46 & .04 \\
\hline & Surirella sp. & 3,270 & 2.93 \\
\hline & Synedra delicattissima & 4,350 & 3.90 \\
\hline & Chlorophyta & & \\
\hline & Chlamydomonas spp. & 28,500 & 25.6 \\
\hline & Chrysophyta & & \\
\hline & Mallomonas producta & 26 & .02 \\
\hline & Cryptophyta & & \\
\hline & Cryptomonas ovata & 38,100 & 34.1 \\
\hline & Euglenophyta & & \\
\hline & Trachelomonas girardiana & 1,590 & 1.43 \\
\hline & Trachelomonas hispida & 1,190 & 1.07 \\
\hline & Trachelomonas similis & 2,840 & 2.54 \\
\hline & Trachelomonas spp. & 25,200 & 22.5 \\
\hline \multirow[t]{21}{*}{$4 / 19 / 2001$} & Bacillariophyta & & \\
\hline & Cymbella sp. & 17 & .01 \\
\hline & Gyrosigma sp. & 2,630 & 1.79 \\
\hline & Melosira granulata & 15,600 & 10.6 \\
\hline & Melosira sp. & 79,100 & 54.0 \\
\hline & Navicula spp. & 11,800 & 8.08 \\
\hline & Pinnularia sp. & 720 & .49 \\
\hline & Surirella & 8,310 & 5.67 \\
\hline & Synedra delicattissima & 67 & .05 \\
\hline & Synedra ulna & 2,320 & 1.58 \\
\hline & Chlorophyta & & \\
\hline & Chlamydomonas spp. & 783 & .53 \\
\hline & Cryptophyta & & \\
\hline & Cryptomonas ovata & 2,160 & 1.47 \\
\hline & Euglenophyta & & \\
\hline & Euglena spp. & 36 & .02 \\
\hline & Trachelomonas girardiana & 1,580 & 1.08 \\
\hline & Trachelomonas hispida & 1,420 & .97 \\
\hline & Trachelomonas pulchella & 3,820 & 2.60 \\
\hline & Trachelomonas volvocina & 5,430 & 3.71 \\
\hline & Trachelomonas spp. & 10,700 & 7.30 \\
\hline \multirow[t]{3}{*}{$5 / 16 / 2001$} & Bacillariophyta & & \\
\hline & Achnanthidium minutissima & 24 & .01 \\
\hline & Cocconeis placentula & 996 & .50 \\
\hline
\end{tabular}


76 Surface-Water-Quality Conditions and Relation to Taste-and-Odor Occurrences in the Lake Olathe Watershed, Northeast Kansas, 2000-02

Table 27. Phytoplankton taxa, biovolume, and relative percentage abundance in water from Cedar Creek at Highway 56, northeast Kansas, 2000-02.-Continued

$\left[\mu \mathrm{m}^{3} / \mathrm{mL}\right.$, cubic micrometers per milliliter of water]

\begin{tabular}{|c|c|c|c|}
\hline $\begin{array}{c}\text { Date } \\
\text { (month/day/year) }\end{array}$ & Taxa & $\begin{array}{c}\text { Biovolume, } \\
\left(\mu \mathrm{m}^{3} / \mathrm{mL}\right)\end{array}$ & $\begin{array}{c}\text { Relative } \\
\text { percentage } \\
\text { abundance }\end{array}$ \\
\hline \multirow[t]{21}{*}{$\overline{5 / 16 / 2001}$} & Bacillariophyta-Continued & & \\
\hline & Cymatopleura solea & 66 & 0.03 \\
\hline & Gyrosigma sp. & 59 & .03 \\
\hline & Melosira sp. & 47,500 & 24.0 \\
\hline & Navicula spp. & 11,200 & 5.64 \\
\hline & Nitzschia spp. & 2,980 & 1.50 \\
\hline & Pinnularia sp. & 1,010 & .51 \\
\hline & Rhoicosphenia curvata & 10,800 & 5.45 \\
\hline & Surirella sp. & 12,000 & 6.09 \\
\hline & Synedra delicattissima & 916 & .46 \\
\hline & Synedra ulna & 1,520 & .77 \\
\hline & Tabellaria spp. & 130 & .07 \\
\hline & Chlorophyta & & \\
\hline & Chlamydomonas spp. & 1,850 & .93 \\
\hline & Closterium peracerosum & 1,430 & .72 \\
\hline & Euglenophyta & & \\
\hline & Euglena spp. & 45,700 & 23.1 \\
\hline & Phacus spp. & 4,630 & 2.34 \\
\hline & Trachelomonas girardiana & 9,540 & 4.82 \\
\hline & Trachelomonas pulchella & 16,300 & 8.24 \\
\hline & Trachelomonas spp. & 29,300 & 14.8 \\
\hline \multirow[t]{16}{*}{$6 / 3 / 2001$} & Bacillariophyta & & \\
\hline & Cocconeis placentula & 18,900 & 6.35 \\
\hline & Cymbella sp. & 13,500 & 4.51 \\
\hline & Epithemia sp. & 8,200 & 2.75 \\
\hline & Fragilaria spp. & 13,200 & 4.43 \\
\hline & Gomphonema sp. & 55,200 & 18.5 \\
\hline & Gyrosigma sp. & 8,970 & 3.01 \\
\hline & Melosira sp. & 64,400 & 21.6 \\
\hline & Melosira varians & 64,600 & 21.7 \\
\hline & Navicula spp. & 18,500 & 6.21 \\
\hline & Nitzschia spp. & 9,520 & 3.19 \\
\hline & Nitzschia levidensis & 2,820 & .95 \\
\hline & Synedra delicattissima & 306 & .10 \\
\hline & Euglenophyta & & \\
\hline & Trachelomonas similis & 3,130 & 1.05 \\
\hline & Trachelomonas spp. & 16,700 & 5.61 \\
\hline \multirow[t]{6}{*}{$6 / 26 / 2001$} & Bacillariophyta & & \\
\hline & Cymbella sp. & 2,900 & 3.74 \\
\hline & Diploneis spp. & 105 & .13 \\
\hline & Gomphonema sp. & 4,710 & 6.08 \\
\hline & Gyrosigma sp. & 6,580 & 8.50 \\
\hline & Melosira sp. & 21,700 & 28.0 \\
\hline
\end{tabular}


Table 27. Phytoplankton taxa, biovolume, and relative percentage abundance in water from Cedar Creek at Highway 56, northeast Kansas, 2000-02. - Continued

[ $\mu \mathrm{m}^{3} / \mathrm{mL}$, cubic micrometers per milliliter of water]

\begin{tabular}{|c|c|c|c|}
\hline $\begin{array}{c}\text { Date } \\
\text { (month/day/year) }\end{array}$ & Taxa & $\begin{array}{l}\text { Biovolume, } \\
\left(\mu \mathrm{m}^{3} / \mathrm{mL}\right)\end{array}$ & $\begin{array}{c}\text { Relative } \\
\text { percentage } \\
\text { abundance }\end{array}$ \\
\hline \multirow[t]{15}{*}{$6 / 26 / 2001$} & Bacillariophyta-Continued & & \\
\hline & Navicula spp. & 3,840 & 4.95 \\
\hline & Rhoicosphenia curvata & 2,430 & 3.13 \\
\hline & Stauroneis sp. & 1,510 & 1.95 \\
\hline & Synedra delicattissima & 153 & .20 \\
\hline & Synedra ulna & 5,790 & 7.48 \\
\hline & Chlorophyta & & \\
\hline & Chlamydomonas spp. & 5,280 & 6.82 \\
\hline & Cryptophyta & & \\
\hline & Cryptomonas ovata & 12,400 & 16.0 \\
\hline & Euglenophyta & & \\
\hline & Euglena spp. & 124 & .16 \\
\hline & Trachelomonas girardiana & 69 & .09 \\
\hline & Trachelomonas similis & 2,870 & 3.71 \\
\hline & Trachelomonas spp. & 7,010 & 9.05 \\
\hline \multirow[t]{19}{*}{$3 / 16 / 2002$} & Bacillariophyta & & \\
\hline & Cocconeis placentula & 31 & .34 \\
\hline & Gomphonema minuta & 419 & 4.57 \\
\hline & Melosira granulata & 1,140 & 12.4 \\
\hline & Synedra delicattissima & 82 & .89 \\
\hline & Synedra spp. & 474 & 5.17 \\
\hline & Chlorophyta & & \\
\hline & Chlamydomonas spp. & 807 & 8.80 \\
\hline & Kirchneriella lunaris & 21 & .23 \\
\hline & Tetrastrum sp. & 218 & 2.38 \\
\hline & Cryptophyta & & \\
\hline & Cryptomonas ovata & 428 & 4.67 \\
\hline & Cryptomonas spp. & 4,460 & 48.6 \\
\hline & Cyanophyta & & \\
\hline & Aphanocapsa spp. & 432 & 4.71 \\
\hline & Microcystis anguina & 193 & 2.10 \\
\hline & Euglenophyta & & \\
\hline & Trachelomonas similis & 28 & .30 \\
\hline & Trachelomonas spp. & 438 & 4.77 \\
\hline \multirow[t]{9}{*}{$4 / 21 / 2002$} & Bacillariophyta & & \\
\hline & Achnanthes spp. & 8,210 & 2.29 \\
\hline & Cyclotella spp. & 9,430 & 2.63 \\
\hline & Eunotia sp. & 167 & .05 \\
\hline & Gomphonema minuta & 2,000 & .56 \\
\hline & Hantzshia sp. & 3,310 & .92 \\
\hline & Melosira islandica & 8,420 & 2.35 \\
\hline & Navicula spp. & 17,100 & 4.77 \\
\hline & Nitzschia sigmoidea & 3,280 & .91 \\
\hline
\end{tabular}


78 Surface-Water-Quality Conditions and Relation to Taste-and-Odor Occurrences in the Lake Olathe Watershed, Northeast Kansas, 2000-02

Table 27. Phytoplankton taxa, biovolume, and relative percentage abundance in water from Cedar Creek at Highway 56, northeast Kansas, 2000-02.-Continued

$\left[\mu \mathrm{m}^{3} / \mathrm{mL}\right.$, cubic micrometers per milliliter of water]

\begin{tabular}{|c|c|c|c|}
\hline $\begin{array}{c}\text { Date } \\
\text { (month/day/year) }\end{array}$ & Taxa & $\begin{array}{l}\text { Biovolume, } \\
\left(\mu \mathrm{m}^{3} / \mathrm{mL}\right)\end{array}$ & $\begin{array}{c}\text { Relative } \\
\text { percentage } \\
\text { abundance }\end{array}$ \\
\hline \multirow[t]{20}{*}{$4 / 21 / 2002$} & Bacillariophyta-Continued & & \\
\hline & Pinnularia sp. & 7,490 & 2.09 \\
\hline & Rhoicosphenia curvata & 1,690 & .47 \\
\hline & Synedra spp. & 20,300 & 5.65 \\
\hline & Synedra ulna & 3,010 & .84 \\
\hline & Chlorophyta & & \\
\hline & Chlamydomonas spp. & 23,300 & 6.49 \\
\hline & Cryptophyta & & \\
\hline & Cryptomonas spp. & 108,000 & 30.2 \\
\hline & Cyanophyta & & \\
\hline & Aphanocapsa delicatissima & 1,080 & .30 \\
\hline & Aphanothece sp. & 51 & .01 \\
\hline & Euglenophyta & & \\
\hline & Euglena spp. & 10,700 & 2.99 \\
\hline & Phacus caudatus & 14,900 & 4.14 \\
\hline & Phacus spp. & 51,000 & 14.2 \\
\hline & Trachelomonas hispida & 21,600 & 6.01 \\
\hline & Trachelomonas pulchella & 493 & .14 \\
\hline & Trachelomonas volvocina & 12,500 & 3.48 \\
\hline & Trachelomonas spp. & 30,500 & 8.49 \\
\hline \multirow[t]{21}{*}{$5 / 12 / 2002$} & Bacillariophyta & & \\
\hline & Achmamthidium minutissima & 2,340 & 1.90 \\
\hline & Caloneis limosa & 3,660 & 2.96 \\
\hline & Cymbella sp. & 1,590 & 1.29 \\
\hline & Gomphonema minuta & 2,700 & 2.19 \\
\hline & Gyrosigma linearis & 2,910 & 2.36 \\
\hline & Melosira islandica & 9,560 & 7.75 \\
\hline & Navicula spp. & 5,250 & 4.26 \\
\hline & Nitzschia sigmoidea & 5,470 & 4.43 \\
\hline & Nitzschia spp. & 14,600 & 11.9 \\
\hline & Synedra delicattissima & 7,180 & 5.82 \\
\hline & Synedra spp. & 5,470 & 4.43 \\
\hline & Synedra ulna & 5,370 & 4.35 \\
\hline & Chlorophyta & & \\
\hline & Chlamydomonas spp. & 25,000 & 20.3 \\
\hline & Cyanophyta & & \\
\hline & Aphanocapsa spp. & 1,820 & 1.47 \\
\hline & Lyngbya sp. & 264 & .21 \\
\hline & Euglenophyta & & \\
\hline & Euglena spp. & 228 & .18 \\
\hline & Trachelomonas spp. & 29,900 & 24.3 \\
\hline
\end{tabular}


Table 28. Phytoplankton taxa, biovolume, and relative percentage abundance in water from Lake Olathe near dam (site 2), northeast Kansas, 2000-02.

$\left[\mu \mathrm{m}^{3} / \mathrm{mL}\right.$, cubic micrometers per milliliter of water]

\begin{tabular}{|c|c|c|c|c|}
\hline Sampling site (fig. 1) & $\begin{array}{c}\text { Date } \\
\text { (month/day/year) }\end{array}$ & Taxa & $\begin{array}{l}\text { Biovolume } \\
\left(\mu \mathrm{m}^{3} / \mathrm{mL}\right)\end{array}$ & $\begin{array}{c}\text { Relative } \\
\text { percentage } \\
\text { abundance }\end{array}$ \\
\hline \multirow[t]{43}{*}{ Site 2 (epilimnion) } & $6 / 1 / 2000$ & Bacillariophyta & & \\
\hline & & Cyclotella spp. & 34,900 & 15.6 \\
\hline & & Fragilaria spp. & 747 & .33 \\
\hline & & Melosira granulata & 48,900 & 21.8 \\
\hline & & Navicula spp. & 961 & .43 \\
\hline & & Nitzschia spp. & 1,420 & .63 \\
\hline & & Nitzschia linearis & 1,100 & .49 \\
\hline & & Chlorophyta & & \\
\hline & & Chlamydomonas snowii & 4,220 & 1.88 \\
\hline & & Chlamydomonas spp. & 14,000 & 6.25 \\
\hline & & Cryptophyta & & \\
\hline & & Rhodomonas minuta & 118,000 & 52.6 \\
\hline & $6 / 20 / 2000$ & Bacillariophyta & & \\
\hline & & Cyclotella spp. & 31,700 & .16 \\
\hline & & Meridion circulare & 2,860 & .01 \\
\hline & & Nitzschia acicularis & 617,000 & 3.16 \\
\hline & & Synedra delicattissima & $5,780,000$ & 29.6 \\
\hline & & Chlorophyta & & \\
\hline & & Chlamydomonas globosa & 1,710 & .01 \\
\hline & & Chlamydomonas spp. & 846,000 & 4.33 \\
\hline & & Chlorella ellipsoidea & 153,000 & .78 \\
\hline & & Closterium acutum & 4,000 & .02 \\
\hline & & Mougeotia sp. & 30,800 & .16 \\
\hline & & Oocystis borgei & 13,700 & .07 \\
\hline & & Oocystis pulsilla & 212,000 & 1.08 \\
\hline & & Pseudosphaerocystis spp. & 50,200 & .26 \\
\hline & & Scenedesmus bijuga & $1,270,000$ & 6.5 \\
\hline & & Scenedesmus quadricauda & 13,700 & .07 \\
\hline & & Sphaerocystis spp. & 420 & 0 \\
\hline & & Chrysophyta & & \\
\hline & & Mallomonas elliptica & 720 & 0 \\
\hline & & Cryptophyta & & \\
\hline & & Cryptomonas spp. & 35,300 & .18 \\
\hline & & Cyanophyta & & \\
\hline & & Anabaena helicoidea & 76,100 & .39 \\
\hline & & Anabaena spp. & $6,300,000$ & 32.3 \\
\hline & & Aphanocapsa spp. & 370,000 & 1.9 \\
\hline & & Chroococcus spp. & 160,000 & .82 \\
\hline & & Cyanarcus spp. & 881 & 0 \\
\hline & & Gleothece spp. & 3,520 & .02 \\
\hline & & Merismopedia tenuissima & 128 & 0 \\
\hline & & Merismopedia sp. & 33,500 & .17 \\
\hline & & Pseudoanabaena spp. & $3,310,000$ & 16.9 \\
\hline
\end{tabular}


80 Surface-Water-Quality Conditions and Relation to Taste-and-Odor Occurrences in the Lake Olathe Watershed, Northeast Kansas, 2000-02

Table 28. Phytoplankton taxa, biovolume, and relative percentage abundance in water from Lake Olathe near dam (site 2), northeast Kansas, 2000-02. - Continued

$\left[\mathrm{m}^{3} / \mathrm{mL}\right.$, cubic micrometers per milliliter of water]

\begin{tabular}{|c|c|c|c|c|}
\hline Sampling site (fig. 1) & $\begin{array}{c}\text { Date } \\
\text { (month/day/year) }\end{array}$ & Taxa & $\begin{array}{l}\text { Biovolume } \\
\left(\mu \mathrm{m}^{3} / \mathrm{mL}\right)\end{array}$ & $\begin{array}{c}\text { Relative } \\
\text { percentage } \\
\text { abundance }\end{array}$ \\
\hline \multirow[t]{36}{*}{ Site 2 (epilimnion)-Continued } & $6 / 20 / 2000$ & Euglenophyta & & \\
\hline & & Euglena spp. & 44,100 & 0.23 \\
\hline & & Lepocinclis acuata & 30,800 & .16 \\
\hline & & Phacus spp. & 2,280 & .01 \\
\hline & & Trachelomonas pulchella & 1,430 & .01 \\
\hline & & Trachelomonas spp. & 110,000 & .56 \\
\hline & & Pyrrophyta & & \\
\hline & & Peridinium spp. & 17,600 & .09 \\
\hline & $6 / 21 / 2000$ & Bacillariophyta & & \\
\hline & & Asterionella formosa & 254,000 & 22.3 \\
\hline & & Cyclotella spp. & 12,700 & 1.11 \\
\hline & & Synedra delicattissima & 42,300 & 3.71 \\
\hline & & Synedra spp. & 10,600 & .93 \\
\hline & & Chlorophyta & & \\
\hline & & Ankistrodesmus falcatus & 33,800 & 2.97 \\
\hline & & Chlamydomonas globosa & 5,290 & .46 \\
\hline & & Chlamydomonas spp. & 3,520 & .31 \\
\hline & & Chlorella ellipsoidea & 15,300 & 1.34 \\
\hline & & Chlorella vulgaris & 31,700 & 2.78 \\
\hline & & Cosmarium spp. & 5,710 & .5 \\
\hline & & Micrasterias radiata & 17,100 & 1.5 \\
\hline & & Scenedesmus bijuga & 16,900 & 1.48 \\
\hline & & Stigeoclonium spp. & 3,120 & .27 \\
\hline & & Treubaria setigerum & 120 & 0 \\
\hline & & Cyanophyta & & \\
\hline & & Anabaena spp. & 127,000 & 11.1 \\
\hline & & Aphanocapsa spp. & 47,600 & 4.17 \\
\hline & & Chroococcus spp. & 19,100 & 1.67 \\
\hline & & Chroococcus turgidis & 4,320 & .38 \\
\hline & & Pseudoanabaena spp. & 425,000 & 37.2 \\
\hline & & Euglenophyta & & \\
\hline & & Euglena acus & 300 & .03 \\
\hline & & Trachelomonas pulchella & 39,700 & 3.48 \\
\hline & & Trachelomonas spp. & 24,200 & 2.12 \\
\hline & & Pyrrophyta & & \\
\hline & & Gymnodinium sp. & 1,320 & .12 \\
\hline \multirow[t]{7}{*}{ Site 2 (hypolimnion) } & $6 / 21 / 2000$ & Bacillariophyta & & \\
\hline & & Asterionella formosa & 10,600 & 5.18 \\
\hline & & Aulacoseira granulata & 1,280 & .63 \\
\hline & & Auxospores & 8,810 & 4.31 \\
\hline & & Cyclotella spp. & 3,170 & 1.55 \\
\hline & & Fragilaria spp. & 128 & .06 \\
\hline & & Melosira granulata & 1,280 & .63 \\
\hline
\end{tabular}


Table 28. Phytoplankton taxa, biovolume, and relative percentage abundance in water from Lake Olathe near dam (site 2), northeast Kansas, 2000-02. - Continued

$\left[\mathrm{m}^{3} / \mathrm{mL}\right.$, cubic micrometers per milliliter of water]

\begin{tabular}{|c|c|c|c|c|}
\hline Sampling site (fig. 1) & $\begin{array}{c}\text { Date } \\
\text { (month/day/year) }\end{array}$ & Taxa & $\begin{array}{l}\text { Biovolume } \\
\left(\mu \mathrm{m}^{3} / \mathrm{mL}\right)\end{array}$ & $\begin{array}{c}\text { Relative } \\
\text { percentage } \\
\text { abundance }\end{array}$ \\
\hline \multirow[t]{27}{*}{ Site 2 (hypolimnion)—Continued } & $6 / 21 / 2000$ & Bacillariophyta-Continued & & \\
\hline & & Navicula cryptonella & 120 & 0.06 \\
\hline & & Navicula spp. & 11,000 & 5.39 \\
\hline & & Navicula viridula & 2,280 & 1.12 \\
\hline & & Neidium ampliatum & 4,860 & 2.38 \\
\hline & & Nitzschia acicularis & 2,470 & 1.21 \\
\hline & & Nitzschia spp. & 3,140 & 1.54 \\
\hline & & Chlorophyta & & \\
\hline & & Ankistrodesmus falcatus & 125 & .06 \\
\hline & & Chlamydomonas globosa & 5,290 & 2.59 \\
\hline & & Chlamydomonas spp. & 7,050 & 3.45 \\
\hline & & Chlorella ellipsoidea & 3,310 & 1.62 \\
\hline & & Chlorella vulgaris & 13,200 & 6.47 \\
\hline & & Selenastrum minutum & 5,990 & 2.93 \\
\hline & & Sphaerocystis spp. & 448 & .22 \\
\hline & & Staurastrum spp. & 16,000 & 7.83 \\
\hline & & Ulothrix subtilissima & 24,700 & 12.1 \\
\hline & & Cyanophyta & & \\
\hline & & Anabaena spp. & 17,400 & 8.54 \\
\hline & & Aphanocapsa spp. & 31,700 & 15.5 \\
\hline & & Chroococcus spp. & 1,230 & .60 \\
\hline & & Merismopedia sp. & 64 & .03 \\
\hline & & Pseudoanabaena spp. & 25,400 & 12.4 \\
\hline & & Euglenophyta & & \\
\hline & & Trachelomonas spp. & 4,410 & 2.16 \\
\hline & & Pyrrophyta & & \\
\hline & & Gymnodinium sp. & 60 & .03 \\
\hline
\end{tabular}

Site 3 (epilimnion)

$6 / 22 / 2000$

Bacillariophyta

Asterionella formosa

$4,570 \quad .74$

Auxospores

5,290

Cyclotella spp.

11,400

1.83

Nitzschia acicularis

59,200

9.50

Rhoicosphenia curvata

2,860

Stephanodiscus nigare

4,000

Chlorophyta

Ankistrodesmus falcatus

Chlamydomonas globosa

Chlorella spp.

25,400

Chlorella ellipsodiea

Chlorella vulgaris

5.09

Closterium acutum

Oocystis borgei 
82 Surface-Water-Quality Conditions and Relation to Taste-and-Odor Occurrences in the Lake Olathe Watershed, Northeast Kansas, 2000-02

Table 28. Phytoplankton taxa, biovolume, and relative percentage abundance in water from Lake Olathe near dam (site 2), northeast Kansas, 2000-02. - Continued

$\left[\mu \mathrm{m}^{3} / \mathrm{mL}\right.$, cubic micrometers per milliliter of water]

\begin{tabular}{|c|c|c|c|c|}
\hline Sampling site (fig. 1) & $\begin{array}{c}\text { Date } \\
\text { (month/day/year) }\end{array}$ & Taxa & $\begin{array}{l}\text { Biovolume } \\
\left(\mu \mathrm{m}^{3} / \mathrm{mL}\right)\end{array}$ & $\begin{array}{c}\text { Relative } \\
\text { percentage } \\
\text { abundance }\end{array}$ \\
\hline \multirow[t]{17}{*}{ Site 3 (epilimnion)—Continued } & $6 / 22 / 2000$ & Chlorophyta-Continued & & \\
\hline & & Scenedesmus bijuga & 11,300 & 1.81 \\
\hline & & Scenedesmus quadricauda & 1,710 & .27 \\
\hline & & Chrysophyta & & \\
\hline & & Dinobryon spp. & 11,300 & 1.81 \\
\hline & & Mallomonas acaroids & 22,000 & 3.53 \\
\hline & & Cryptophyta & & \\
\hline & & Cryptomonas erosa & 2,570 & .41 \\
\hline & & Cryptomonas spp. & 3,520 & .56 \\
\hline & & Cyanophyta & & 3.34 \\
\hline & & Anabaena circinalis & 20,800 & 3.34 \\
\hline & & Anabaena spp. & 268,000 & 42.9 \\
\hline & & Euglenophyta & & \\
\hline & & Phacus spp. & 2,280 & .37 \\
\hline & & Trachelomonas pulchella & 26,400 & 4.24 \\
\hline & & Trachelomonas rotunda & 10,600 & 1.70 \\
\hline & & Trachelomonas spp. & 30,800 & 4.95 \\
\hline \multirow[t]{27}{*}{ Site 3 (epilimnion) } & $6 / 22 / 2000$ & Bacillariophyta & & \\
\hline & & Achnanthidium minutissima & 2,470 & .37 \\
\hline & & Asterionella formosa & 480 & .07 \\
\hline & & Auxospores & 24,700 & 3.67 \\
\hline & & Cyclotella spp. & 16,900 & 2.51 \\
\hline & & Fragilaria capucina & 1,540 & .23 \\
\hline & & Gomphonema parvulum & 1,720 & .26 \\
\hline & & Navicula trivialis & 2,280 & .34 \\
\hline & & Navicula gregaria & 5,020 & .75 \\
\hline & & Nitzschia acicularis & 29,600 & 4.40 \\
\hline & & Nitzschia spp. & 48,500 & 7.21 \\
\hline & & Nitzschia levidensis & 160 & .02 \\
\hline & & Nitzschia palea & 1,140 & .17 \\
\hline & & Stephanodiscus nigare & 8,000 & 1.19 \\
\hline & & Chlorophyta & & \\
\hline & & Chlamydomonas globosa & 10,600 & 1.57 \\
\hline & & Chlamydomonas spp. & 33,500 & 4.98 \\
\hline & & Chlorella ellipsodiea & 30,700 & 4.56 \\
\hline & & Chlorella vulgaris & 5,290 & .79 \\
\hline & & Pediastrum simplex & 14,100 & 2.10 \\
\hline & & Quadrigula lacustris & 4,850 & .72 \\
\hline & & Scenedesmus bijuga & 128 & .02 \\
\hline & & Cyanophyta & & \\
\hline & & Anabaena spp. & 81,800 & 12.2 \\
\hline & & Aphanocapsa spp. & 36 & 0 \\
\hline & & Chroococcus spp. & 11,100 & 1.65 \\
\hline & & Chroococcus minor & 57 & .01 \\
\hline
\end{tabular}


Table 28. Phytoplankton taxa, biovolume, and relative percentage abundance in water from Lake Olathe near dam (site 2), northeast Kansas, 2000-02. - Continued

$\left[\mathrm{m}^{3} / \mathrm{mL}\right.$, cubic micrometers per milliliter of water]

\begin{tabular}{|c|c|c|c|c|}
\hline Sampling site (fig. 1) & $\begin{array}{c}\text { Date } \\
\text { (month/day/year) }\end{array}$ & Taxa & $\begin{array}{l}\text { Biovolume } \\
\left(\mu \mathrm{m}^{3} / \mathrm{mL}\right)\end{array}$ & $\begin{array}{c}\text { Relative } \\
\text { percentage } \\
\text { abundance }\end{array}$ \\
\hline \multirow[t]{11}{*}{ Site 3 (epilimnion)—Continued } & $6 / 22 / 2000$ & Cyanophyta-Continued & & \\
\hline & & Chroococcus turgidis & 800 & 0.12 \\
\hline & & Psuedoanabaena spp. & 272,000 & 40.5 \\
\hline & & Pyrrophyta & & \\
\hline & & Glenodinium sp. & 1,150 & .17 \\
\hline & & Peridinium spp. & 571 & .08 \\
\hline & & Euglenophyta & & \\
\hline & & Phacus spp. & 2,280 & .34 \\
\hline & & Trachelomonas pulchella & 26,400 & 3.93 \\
\hline & & Trachelomonas rotunda & 3,520 & .52 \\
\hline & & Trachelomonas spp. & 30,800 & 4.59 \\
\hline \multirow[t]{18}{*}{ Site 2 (epilimnion) } & $10 / 24 / 2000$ & Bacillariophyta & & \\
\hline & & Cymatopleura solea & 60 & .02 \\
\hline & & Fragilaria capucina & 14,700 & 4.97 \\
\hline & & Melosira islandica & 29,700 & 10.00 \\
\hline & & Navicula spp. & 263 & .09 \\
\hline & & Surirella ovata & 36 & .01 \\
\hline & & Chlorophyta & & \\
\hline & & Chlamydomonas globosa & 59,600 & 20.0 \\
\hline & & Closterium sp. & 23 & .01 \\
\hline & & Scenedesmus bijuga & 3,550 & 1.20 \\
\hline & & Cryptophyta & & \\
\hline & & Cryptomonas spp. & 68,100 & 22.9 \\
\hline & & Rhodomonas minuta & 11,800 & 3.96 \\
\hline & & Cyanophyta & & \\
\hline & & Anabaena circinalis & 3,650 & 1.23 \\
\hline & & Anabaena spp. & 2,410 & .81 \\
\hline & & Euglenophyta & & \\
\hline & & Trachelomonas spp. & 103,000 & 34.7 \\
\hline \multirow[t]{14}{*}{ Site 3 (epilimnion) } & $10 / 24 / 2000$ & Bacillariophyta & & \\
\hline & & Cyclotella spp. & 2,570 & .31 \\
\hline & & Fragilaria capucina & 146 & .02 \\
\hline & & Melosira granulata & 11,800 & 1.44 \\
\hline & & Melosira islandica & 2,870 & .35 \\
\hline & & Navicula spp. & 2,270 & .28 \\
\hline & & Synedra ulna & 322 & .04 \\
\hline & & Chlorophyta & & \\
\hline & & Chlamydomonas spp. & 315,000 & 38.4 \\
\hline & & Cryptophyta & & \\
\hline & & Cryptomonas spp. & 49,600 & 6.05 \\
\hline & & Cyanophyta & & \\
\hline & & Anabaena circinalis & 1,640 & .20 \\
\hline & & Anabaena spp. & 603 & .07 \\
\hline
\end{tabular}


84 Surface-Water-Quality Conditions and Relation to Taste-and-Odor Occurrences in the Lake Olathe Watershed, Northeast Kansas, 2000-02

Table 28. Phytoplankton taxa, biovolume, and relative percentage abundance in water from Lake Olathe near dam (site 2), northeast Kansas, 2000-02. - Continued

[ $\mu \mathrm{m}^{3} / \mathrm{mL}$, cubic micrometers per milliliter of water]

\begin{tabular}{|c|c|c|c|c|}
\hline Sampling site (fig. 1) & $\begin{array}{c}\text { Date } \\
\text { (month/day/year) }\end{array}$ & Taxa & $\begin{array}{l}\text { Biovolume } \\
\left(\mu \mathrm{m}^{3} / \mathrm{mL}\right)\end{array}$ & $\begin{array}{c}\text { Relative } \\
\text { percentage } \\
\text { abundance }\end{array}$ \\
\hline \multirow{3}{*}{ Site 3 (epilimnion)_-Continued } & $10 / 24 / 2000$ & Euglenophyta & & \\
\hline & & Trachelomonas volvocina & 139,000 & 17.0 \\
\hline & & Trachelomonas spp. & 293,000 & 35.8 \\
\hline \multirow[t]{12}{*}{ Site 2 (epilimnion) } & $3 / 20 / 2001$ & Bacillariophyta & & \\
\hline & & Cyclotella spp. & 49,600 & 63.4 \\
\hline & & Nitzschia spp. & 223 & .28 \\
\hline & & Surirella ovata & 42 & .05 \\
\hline & & Synedra delicattissima & 851 & 1.09 \\
\hline & & Synedra ulna & 2,760 & 3.53 \\
\hline & & Chlorophyta & & \\
\hline & & Chlamydomonas spp. & 17,500 & 22.4 \\
\hline & & Cryptophyta & & \\
\hline & & Cryptomonas ovata & 2,980 & 3.81 \\
\hline & & Euglenophyta & & \\
\hline & & Trachelomonas pulchella & 4,250 & 5.43 \\
\hline \multirow[t]{17}{*}{ Site 3 (epilimnion) } & $3 / 20 / 2001$ & Bacillariophyta & & \\
\hline & & Cyclotella spp. & 27,500 & 16.4 \\
\hline & & Fragilaria crotonensis & 2,440 & 1.45 \\
\hline & & Gomphonema sp. & 600 & .36 \\
\hline & & Melosira islandica & 2,530 & 1.50 \\
\hline & & Melosira sp. & 7,840 & 4.65 \\
\hline & & Stauroneis sp. & 44 & .03 \\
\hline & & Synedra delicattissima & 1,450 & .86 \\
\hline & & Synedra ulna & 1,210 & .72 \\
\hline & & Chlorophyta & & \\
\hline & & Chlamydomonas spp. & 64,300 & 38.2 \\
\hline & & Cryptophyta & & \\
\hline & & Cryptomonas ovata & 35,300 & 21.0 \\
\hline & & Euglenophyta & & \\
\hline & & Trachelomonas hispida & 28 & .02 \\
\hline & & Trachelomonas pulchella & 7,770 & 4.61 \\
\hline & & Trachelomonas spp. & 17,400 & 10.4 \\
\hline \multirow[t]{8}{*}{ Site 2 (epilimnion) } & $4 / 18 / 2001$ & Bacillariophyta & & \\
\hline & & Asterionella formosa & 228 & .10 \\
\hline & & Cyclotella spp. & 8,630 & 3.98 \\
\hline & & Cymbella sp. & 20 & .01 \\
\hline & & Gyrosigma sp. & 66 & .03 \\
\hline & & Melosira sp. & 58,000 & 26.8 \\
\hline & & Surirella ovata & 52 & .02 \\
\hline & & Synedra delicattissima & 67 & .03 \\
\hline
\end{tabular}


Table 28. Phytoplankton taxa, biovolume, and relative percentage abundance in water from Lake Olathe near dam (site 2), northeast Kansas, 2000-02. - Continued

$\left[\mathrm{m}^{3} / \mathrm{mL}\right.$, cubic micrometers per milliliter of water]

\begin{tabular}{|c|c|c|c|c|}
\hline Sampling site (fig. 1) & $\begin{array}{c}\text { Date } \\
\text { (month/day/year) }\end{array}$ & Taxa & $\begin{array}{l}\text { Biovolume } \\
\left(\mu \mathrm{m}^{3} / \mathrm{mL}\right)\end{array}$ & $\begin{array}{c}\text { Relative } \\
\text { percentage } \\
\text { abundance }\end{array}$ \\
\hline \multirow{13}{*}{ Site 2 (epilimnion)—Continued } & $4 / 18 / 2001$ & Chlorophyta & & \\
\hline & & Ankistrodesmus falcatus & 233 & 0.11 \\
\hline & & Chlamydomonas spp. & 90,900 & 42.0 \\
\hline & & Closterium moniliferum & 52 & .02 \\
\hline & & Elakotothrix gelatinosa & 25 & .01 \\
\hline & & Cryptophyta & & \\
\hline & & Cryptomonas ovata & 44,300 & 20.5 \\
\hline & & Rhodomonas lacustris & 11,900 & 5.51 \\
\hline & & Cyanophyta & & \\
\hline & & Aphanocapsa delicatissima & 627 & .29 \\
\hline & & Euglenophyta & & \\
\hline & & Trachelomonas pulchella & 1,120 & .51 \\
\hline & & Trachelomonas spp. & 263 & .12 \\
\hline \multirow[t]{12}{*}{ Site 2 (hypolimnion) } & $4 / 18 / 2001$ & Bacillariophyta & & \\
\hline & & Cyclotella spp. & 7,860 & 10.8 \\
\hline & & Melosira granulata & 4,370 & 6.01 \\
\hline & & Melosira sp. & 57,300 & 78.8 \\
\hline & & Navicula spp. & 13 & .02 \\
\hline & & Synedra ulna & 397 & .55 \\
\hline & & Tabellaria flocculosa & 91 & .12 \\
\hline & & Chlorophyta & & \\
\hline & & Chlamydomonas spp. & 943 & 1.30 \\
\hline & & Euglenophyta & & \\
\hline & & Trachelomonas pulchella & 732 & 1.01 \\
\hline & & Trachelomonas spp. & 1,030 & 1.41 \\
\hline \multirow[t]{18}{*}{ Site 2 (epilimnion) } & $5 / 17 / 2001$ & Bacillariophyta & & \\
\hline & & Asterionella formosa & 19,300 & 7.00 \\
\hline & & Cyclotella spp. & 2,340 & .85 \\
\hline & & Cymbella sp. & 360 & .13 \\
\hline & & Melosira islandica & 79,000 & 28.7 \\
\hline & & Melosira sp. & 68,100 & 24.8 \\
\hline & & Melosira varians & 16,600 & 6.04 \\
\hline & & Surirella ovata & 634 & .23 \\
\hline & & Synedra delicattissima & 6,330 & 2.30 \\
\hline & & Synedra ulna & 530 & .19 \\
\hline & & Chlorophyta & & \\
\hline & & Asterococcus limneticus & 70 & .02 \\
\hline & & Chlamydomonas spp. & 14,200 & 5.15 \\
\hline & & Closterium sp. & 1,710 & .62 \\
\hline & & Planktosphaeria gelatinosa & 4,090 & 1.49 \\
\hline & & Scenedesmus quadricauda & 857 & .31 \\
\hline & & Scenedesmus sp. & 22 & .01 \\
\hline & & Sphaerocystis schroeteri & 2,820 & 1.02 \\
\hline
\end{tabular}


86 Surface-Water-Quality Conditions and Relation to Taste-and-Odor Occurrences in the Lake Olathe Watershed, Northeast Kansas, 2000-02

Table 28. Phytoplankton taxa, biovolume, and relative percentage abundance in water from Lake Olathe near dam (site 2), northeast Kansas, 2000-02. - Continued

$\left[\mu \mathrm{m}^{3} / \mathrm{mL}\right.$, cubic micrometers per milliliter of water]

\begin{tabular}{|c|c|c|c|c|}
\hline Sampling site (fig. 1) & $\begin{array}{c}\text { Date } \\
\text { (month/day/year) }\end{array}$ & Taxa & $\begin{array}{l}\text { Biovolume } \\
\left(\mu \mathrm{m}^{3} / \mathrm{mL}\right)\end{array}$ & $\begin{array}{c}\text { Relative } \\
\text { percentage } \\
\text { abundance }\end{array}$ \\
\hline \multirow[t]{7}{*}{ Site 2 (epilimnion) —Continued } & $5 / 17 / 2001$ & Chrysophyta & & \\
\hline & & Mallomonas producta & 21 & 0.01 \\
\hline & & Cryptophyta & & \\
\hline & & Cryptomonas ovata & 55,800 & 20.3 \\
\hline & & Euglenophyta & & \\
\hline & & Phacus spp. & 594 & .22 \\
\hline & & Trachelomonas spp. & 1,650 & .60 \\
\hline \multirow[t]{7}{*}{ Site 2 (hypolimnion) } & $5 / 17 / 2001$ & Bacillariophyta & & \\
\hline & & Asterionella formosa & 7,700 & 17.0 \\
\hline & & Cyclotella spp. & 1,890 & 4.16 \\
\hline & & Melosira islandica & 4,110 & 9.05 \\
\hline & & Melosira sp. & 30,800 & 67.8 \\
\hline & & Stauroneis sp. & 28 & .06 \\
\hline & & Synedra delicattissima & 874 & 1.92 \\
\hline \multirow[t]{27}{*}{ Site 2 (epilimnion) } & $6 / 27 / 2001$ & Bacillariophyta & & \\
\hline & & Fragilaria spp. & 53,200 & 8.86 \\
\hline & & Melosira granulata & 121,000 & 20.2 \\
\hline & & Chlorophyta & & \\
\hline & & Actinastrum hantzschii & 6,980 & 1.16 \\
\hline & & Asterococcus limneticus & 18,300 & 3.05 \\
\hline & & Chlamydomonas spp. & 227,000 & 37.8 \\
\hline & & Closterium moniliferum & 550 & .09 \\
\hline & & Crucigenia apiculata & 126 & .02 \\
\hline & & Pediastrum duplex & 12,300 & 2.04 \\
\hline & & Pediastrum simplex & 1,460 & .24 \\
\hline & & Sphaerocystis schroeteri & 5,180 & .86 \\
\hline & & Chrysophyta & & \\
\hline & & Mallomonas producta & 2,220 & .37 \\
\hline & & Cryptophyta & & \\
\hline & & Cryptomonas ovata & 108,000 & 17.9 \\
\hline & & Cyanophyta & & \\
\hline & & Anabaena circinalis & 15 & 0 \\
\hline & & Anabaena spp. & 4,700 & .78 \\
\hline & & Chrococcus dispersus & 274 & .04 \\
\hline & & Oscillatoria limnetica & 21,400 & 3.56 \\
\hline & & Euglenophyta & & \\
\hline & & Trachelomonas hexangulata & 41 & .01 \\
\hline & & Trachelomonas similis & 1,400 & .23 \\
\hline & & Trachelomonas spp. & 14,500 & 2.42 \\
\hline & & Pyrrophyta & & \\
\hline & & Peridinium spp. & 1,880 & .31 \\
\hline
\end{tabular}


Table 28. Phytoplankton taxa, biovolume, and relative percentage abundance in water from Lake Olathe near dam (site 2), northeast Kansas, 2000-02. - Continued

$\left[\mathrm{m}^{3} / \mathrm{mL}\right.$, cubic micrometers per milliliter of water]

\begin{tabular}{|c|c|c|c|c|}
\hline Sampling site (fig. 1) & $\begin{array}{c}\text { Date } \\
\text { (month/day/year) }\end{array}$ & Taxa & $\begin{array}{l}\text { Biovolume } \\
\left(\mu \mathrm{m}^{3} / \mathrm{mL}\right)\end{array}$ & $\begin{array}{c}\text { Relative } \\
\text { percentage } \\
\text { abundance }\end{array}$ \\
\hline \multirow[t]{11}{*}{ Site 2 (hypolimnion) } & $6 / 27 / 2001$ & Bacillariophyta & & \\
\hline & & Cyclotella spp. & 47,900 & 47.0 \\
\hline & & Fragilaria spp. & 20,700 & 20.3 \\
\hline & & Melosira granulata & 11,600 & 11.4 \\
\hline & & Tabellaria fenestrata & 4,200 & 4.12 \\
\hline & & Cyanophyta & & \\
\hline & & Oscillatoria agardhii & 13,000 & 12.7 \\
\hline & & Pyrrophyta & & \\
\hline & & Peridinium spp. & 1,350 & 1.32 \\
\hline & & Euglenophyta & & \\
\hline & & Trachelomonas spp. & 3,150 & 3.09 \\
\hline \multirow[t]{25}{*}{ Site 2 (epilimnion) } & $8 / 14 / 2001$ & Bacillariophyta & & \\
\hline & & Cyclotella spp. & 34,800 & 4.57 \\
\hline & & Fragilaria capucina & 7,450 & .98 \\
\hline & & Melosira islandica & 296,000 & 38.9 \\
\hline & & Nitzschia linearis & 126 & .02 \\
\hline & & Synedra ulna & 39,700 & 5.21 \\
\hline & & Chlorophyta & & \\
\hline & & Chlamydomonas spp. & 32,300 & 4.24 \\
\hline & & Cosmarium spp. & 1,970 & .26 \\
\hline & & Chrysophyta & & \\
\hline & & Mallomonas producta & 192 & .02 \\
\hline & & Mallomonas sp. & 4,540 & .60 \\
\hline & & Cryptophyta & & \\
\hline & & Cryptomonas ovata & 5,040 & .66 \\
\hline & & Rhodomonas lacustris & 24,400 & 3.21 \\
\hline & & Cyanophyta & & \\
\hline & & Anabaena circinalis & 27,100 & 3.56 \\
\hline & & Anabaena flo-aquae & 180,000 & 23.7 \\
\hline & & Anbaena spp. & 66,900 & 8.79 \\
\hline & & Coelosphaerium sp. & 264 & .03 \\
\hline & & Dactykococcopsis sp. & 1,940 & .25 \\
\hline & & Leptolyngbya sp. & 20,100 & 2.64 \\
\hline & & Psuedoanabaena spp. & 13,500 & 1.77 \\
\hline & & Euglenophyta & & \\
\hline & & Phacus spp. & 4,230 & .55 \\
\hline \multirow[t]{6}{*}{ Site 2 (hypolimnion) } & $8 / 14 / 2001$ & Bacillariophyta & & \\
\hline & & Cyclotella spp. & 9,720 & 6.59 \\
\hline & & Melosira islandica & 9,960 & 6.75 \\
\hline & & Melosira sp. & 44,500 & 30.2 \\
\hline & & Surirella ovata & 182 & .12 \\
\hline & & Synedra ulna & 13,800 & 9.37 \\
\hline
\end{tabular}


88 Surface-Water-Quality Conditions and Relation to Taste-and-Odor Occurrences in the Lake Olathe Watershed, Northeast Kansas, 2000-02

Table 28. Phytoplankton taxa, biovolume, and relative percentage abundance in water from Lake Olathe near dam (site 2), northeast Kansas, 2000-02. - Continued

$\left[\mathrm{m}^{3} / \mathrm{mL}\right.$, cubic micrometers per milliliter of water]

\begin{tabular}{|c|c|c|c|c|}
\hline Sampling site (fig. 1) & $\begin{array}{c}\text { Date } \\
\text { (month/day/year) }\end{array}$ & Taxa & $\begin{array}{l}\text { Biovolume } \\
\left(\mu \mathrm{m}^{3} / \mathrm{mL}\right)\end{array}$ & $\begin{array}{c}\text { Relative } \\
\text { percentage } \\
\text { abundance }\end{array}$ \\
\hline \multirow[t]{14}{*}{ Site 2 (hypolimnion) } & $8 / 14 / 2001$ & Chlorophyta & & \\
\hline & & Pandorina morum & 237 & 0.16 \\
\hline & & Cryptophyta & & \\
\hline & & Rhodomonas lacustris & 15,700 & 10.6 \\
\hline & & Cyanophyta & & \\
\hline & & Anabaena circinalis & 4,830 & 3.27 \\
\hline & & Anabaena spp. & 20,500 & 13.9 \\
\hline & & Aphanocapsa spp. & 5,050 & 3.43 \\
\hline & & Coelosphaerium pallidum & 229 & .15 \\
\hline & & Leptolyngbya sp. & 7,150 & 4.85 \\
\hline & & Merismopedia punctata & 38 & .02 \\
\hline & & Psuedoanabaena spp. & 1,120 & .76 \\
\hline & & Euglenophyta & & \\
\hline & & Trachelomonas spp. & 14,400 & 9.74 \\
\hline \multirow[t]{30}{*}{ Site 3 (epilimnion) } & $8 / 15 / 2001$ & Bacillariophyta & & \\
\hline & & Cyclotella spp. & 84,000 & 11.1 \\
\hline & & Melosira islandica & 121,000 & 16.0 \\
\hline & & Melosira sp. & 37,400 & 4.93 \\
\hline & & Synedra delicattissima & 350 & .05 \\
\hline & & Synedra ulna & 11,400 & 1.50 \\
\hline & & Chlorophyta & & \\
\hline & & Actinastrum hantzschii & 195 & .02 \\
\hline & & Chlamydomonas spp. & 62,300 & 8.21 \\
\hline & & Cosmarium spp. & 2,340 & .31 \\
\hline & & Chrysophyta & & \\
\hline & & Mallomonas producta & 2,100 & .28 \\
\hline & & Mallomonas sp. & 5,200 & .68 \\
\hline & & Cryptophyta & & \\
\hline & & Rhodomonas lacustris & 24,400 & 3.22 \\
\hline & & Cyanophyta & & \\
\hline & & Anabaena circinalis & 28,600 & 3.77 \\
\hline & & Anabaena flo-aquae & 212,000 & 28.0 \\
\hline & & Anbaena spp. & 42,400 & 5.59 \\
\hline & & Dactylococcopsis sp. & 70 & .01 \\
\hline & & Psuedoanabaena spp. & 8,300 & 1.09 \\
\hline & & Euglenophyta & & \\
\hline & & Euglena spp. & 3,610 & .48 \\
\hline & & Phacus spp. & 224 & .03 \\
\hline & & Trachelomonas girardiana & 192 & .02 \\
\hline & & Trachelomonas pulchella & 1,970 & .26 \\
\hline & & Trachelomonas spp. & 44,300 & 5.84 \\
\hline & & Pyrrophyta & & \\
\hline & & Glenodinium sp. & 9,370 & 1.23 \\
\hline & & Peridinium spp. & 56,200 & 7.41 \\
\hline
\end{tabular}


Table 28. Phytoplankton taxa, biovolume, and relative percentage abundance in water from Lake Olathe near dam (site 2), northeast Kansas, 2000-02. - Continued

$\left[\mathrm{m}^{3} / \mathrm{mL}\right.$, cubic micrometers per milliliter of water]

\begin{tabular}{cccc}
\hline & Date & Taxa & Biovolume \\
$\left(\mu \mathrm{m}^{3} / \mathrm{mL}\right)$ & $\begin{array}{c}\text { Relative } \\
\text { percentage } \\
\text { abundance }\end{array}$ & $\begin{array}{c}\text { (month/day/year) } \\
\end{array}$
\end{tabular}

Site 2 (epilimnion)

$10 / 23 / 2001$

Bacillariophyta

Cyclotella spp.

7,780

0.79

Cymbella sp.

3,330

.34

Fragilaria spp.

71,200

7.21

Melosira granulata

205,000

20.8

Synedra delicattissima

1,090

.11

Synedra spp.

43,800

4.44

Chlorophyta

Actinastrum hantzschii

$2,470 \quad .25$

Ankistrodesmus falcatus

1,180

.12

Chlamydomonas spp.

79,100

8.02

Closteriopsis sp.

368

.04

Closterium moniliferum

246

.02

Crucigenia apiculata

2,850

Crucigenia sp.

3,080

.31

Scenedesmus arcuatus

20,300

2.06

Scenedesmus bijuga

18,300

1.85

Scenedesmus quadricauda

0

Scenedesmus sp.

9,990

1.01

Chrysophyta

Mallomonas producta

406

Cryptophyta

Cryptomonas spp.

32.2

Rhodomonas lacustris

317,000

\section{Cyanophyta}

Anabaena circinalis

12,400

.42

Anabaena macrospora

4,190

.31

Anabaena spp.

3,090

1.35

Aphanizomenon flos-aquae

13,300

0

Chroococcus dispersus

0

Coelosphaerium pallidum

.15

Lyngbya limnetica

510

.35

Merismopedia tenuissima

3,460

Microcystis aeruginosa

Microcystis sp.

1,510

Oscillatoria $s p$.

0

Psuedoanabaena spp.

Euglenophyta

Euglena spp.

Trachelomonas girardiana

Trachelomonas hispida

Trachelomonas superba

Trachelomonas spp.

24,800

353 
90 Surface-Water-Quality Conditions and Relation to Taste-and-Odor Occurrences in the Lake Olathe Watershed, Northeast Kansas, 2000-02

Table 28. Phytoplankton taxa, biovolume, and relative percentage abundance in water from Lake Olathe near dam (site 2), northeast Kansas, 2000-02. - Continued

$\left[\mathrm{m}^{3} / \mathrm{mL}\right.$, cubic micrometers per milliliter of water]

\begin{tabular}{|c|c|c|c|c|}
\hline Sampling site (fig. 1) & $\begin{array}{c}\text { Date } \\
\text { (month/day/year) }\end{array}$ & Taxa & $\begin{array}{l}\text { Biovolume } \\
\left(\mu \mathrm{m}^{3} / \mathrm{mL}\right)\end{array}$ & $\begin{array}{c}\text { Relative } \\
\text { percentage } \\
\text { abundance }\end{array}$ \\
\hline \multirow{43}{*}{ Site 2 (epilimnion)_-Continued } & $10 / 23 / 2001$ & Pyrrophyta & & \\
\hline & & Ceratium hirundinella & 4,390 & 0.44 \\
\hline & & Glenodinium sp. & 67 & .01 \\
\hline & & Peridinium spp. & 2,440 & .25 \\
\hline & $2 / 21 / 2002$ & Bacillariophyta & & \\
\hline & & Cyclotella spp. & 3,420 & 2.46 \\
\hline & & Cymbella sp. & 524 & .38 \\
\hline & & Fragilaria crotonensis & 56 & .04 \\
\hline & & Gomphonema sp. & 61 & .04 \\
\hline & & Melosira granulata & 37,200 & 26.7 \\
\hline & & Synedra ulna & 6,910 & 4.97 \\
\hline & & Chlorophyta & & \\
\hline & & Ankistrodesmus falcatus & 5,660 & 4.07 \\
\hline & & Chlamydomonas spp. & 3,850 & 2.77 \\
\hline & & Closteriopsis gracile & 2,410 & 1.73 \\
\hline & & Closterium sp. & 1,340 & .96 \\
\hline & & Cryptophyta & & \\
\hline & & Cryptomonas spp. & 69,800 & 50.2 \\
\hline & & Rhodomonas lacustris & 4,350 & 3.13 \\
\hline & & Cyanophyta & & \\
\hline & & Lyngbya limnetica & 768 & .55 \\
\hline & & Euglenophyta & & \\
\hline & & Trachelomonas spp. & 1,420 & 1.02 \\
\hline & & Pyrrophyta & & \\
\hline & & Peridinium inconspicuum & 1,220 & .88 \\
\hline & $4 / 23 / 2002$ & Bacillariophyta & & \\
\hline & & Asterionella formosa & 18,300 & 7.63 \\
\hline & & Cyclotella spp. & 8,900 & 3.71 \\
\hline & & Melosira granulata & 28,000 & 11.6 \\
\hline & & Melosira islandica & 56,800 & 23.6 \\
\hline & & Melosira varians & 210 & .08 \\
\hline & & Synedra delicattissima & 24,100 & 10.0 \\
\hline & & Synedra spp. & 8,440 & 3.51 \\
\hline & & Synedra ulna & 3,030 & 1.26 \\
\hline & & Chlorophyta & & \\
\hline & & Ankistrodesmus falcatus & 1,650 & .68 \\
\hline & & Chlamydomonas spp. & 11,300 & 4.70 \\
\hline & & Closterium sp. & 3,830 & 1.59 \\
\hline & & Chrysophyta & & \\
\hline & & Mallomonas producta & 1,360 & .57 \\
\hline & & Mallomonas sp & 1,220 & .51 \\
\hline & & Cryptophyta & & \\
\hline & & Cryptmonas spp. & 23,800 & 9.91 \\
\hline
\end{tabular}


Table 28. Phytoplankton taxa, biovolume, and relative percentage abundance in water from Lake Olathe near dam (site 2), northeast Kansas, 2000-02. - Continued

$\left[\mathrm{m}^{3} / \mathrm{mL}\right.$, cubic micrometers per milliliter of water]

\begin{tabular}{|c|c|c|c|c|}
\hline Sampling site (fig. 1) & $\begin{array}{c}\text { Date } \\
\text { (month/day/year) }\end{array}$ & Taxa & $\begin{array}{l}\text { Biovolume } \\
\left(\mu \mathrm{m}^{3} / \mathrm{mL}\right)\end{array}$ & $\begin{array}{c}\text { Relative } \\
\text { percentage } \\
\text { abundance }\end{array}$ \\
\hline \multirow[t]{42}{*}{ Site 2 (epilimnion)—Continued } & $4 / 23 / 2002$ & Cyanophyta & & \\
\hline & & Aphanocapsa spp. & 194 & 0.08 \\
\hline & & Oscillatoria sp. & 60 & .02 \\
\hline & & Euglenophyta & & \\
\hline & & Euglena spp. & 1,880 & .78 \\
\hline & & Trachelomonas hispida & 8,130 & 3.39 \\
\hline & & Trachelomonas volvocina & 6,520 & 2.72 \\
\hline & & Trachelomonas spp. & 25,100 & 10.4 \\
\hline & & Pyrrophyta & & \\
\hline & & Ceratium hirundinella & 7,400 & 3.08 \\
\hline & $6 / 4 / 2002$ & Bacillariophyta & & \\
\hline & & Asterionella formosa & 18,800 & 2.80 \\
\hline & & Cyclotella spp. & 24,600 & 3.66 \\
\hline & & Cymbella sp. & 32 & 0 \\
\hline & & Fragilaria crotonensis & 151 & .02 \\
\hline & & Melosira granulata & 45,800 & 6.82 \\
\hline & & Melosira islandica & 80,600 & 12.0 \\
\hline & & Nitzschia spp. & 471 & .07 \\
\hline & & Rhoicosphenia curvata & 62 & .01 \\
\hline & & Synedra delicattissima & 10,800 & 1.61 \\
\hline & & Synedra spp. & 2,310 & .34 \\
\hline & & Synedra ulna & 4,010 & .60 \\
\hline & & Chlorophyta & & \\
\hline & & Actinastrum hantzschii & 2,280 & .34 \\
\hline & & Chlamydomonas spp. & 371,000 & 55.2 \\
\hline & & Closterium sp. & 41 & .01 \\
\hline & & Eudorina elegans & 6,110 & .91 \\
\hline & & Pandorina morum & 2,580 & .38 \\
\hline & & Scenedesmus incrassatulus & 754 & .11 \\
\hline & & Scenedesmus quadricauda & 400 & .06 \\
\hline & & Cryptophyta & & \\
\hline & & Cryptomonas spp. & 33,300 & 4.96 \\
\hline & & Rhodomonas lacustris & 52,000 & 7.74 \\
\hline & & Cyanophyta & & \\
\hline & & Aphanocapsa spp. & 35 & 0 \\
\hline & & Merismopedia elegans & 6 & 0 \\
\hline & & Euglenophyta & & \\
\hline & & Euglena spp. & 52 & .01 \\
\hline & & Trachelomonas girardiana & 4,960 & .74 \\
\hline & & Trachelomonas superba & 80 & .01 \\
\hline & & Trachelomonas volvocina & 935 & .14 \\
\hline & & Trachelomonas spp. & 7,990 & 1.19 \\
\hline
\end{tabular}


92 Surface-Water-Quality Conditions and Relation to Taste-and-Odor Occurrences in the Lake Olathe Watershed, Northeast Kansas, 2000-02

Table 28. Phytoplankton taxa, biovolume, and relative percentage abundance in water from Lake Olathe near dam (site 2), northeast Kansas, 2000-02. - Continued

$\left[\mu \mathrm{m}^{3} / \mathrm{mL}\right.$, cubic micrometers per milliliter of water]

\begin{tabular}{|c|c|c|c|c|}
\hline Sampling site (fig. 1) & $\begin{array}{c}\text { Date } \\
\text { (month/day/year) }\end{array}$ & Taxa & $\begin{array}{l}\text { Biovolume } \\
\left(\mu \mathrm{m}^{3} / \mathrm{mL}\right)\end{array}$ & $\begin{array}{c}\text { Relative } \\
\text { percentage } \\
\text { abundance }\end{array}$ \\
\hline \multirow[t]{23}{*}{ Site 2 (epilimnion) —Continued } & $6 / 4 / 2002$ & Pyrrophyta & & \\
\hline & & Glenodinium sp. & 1,360 & 0.20 \\
\hline & & Peridinium spp. & 61 & .01 \\
\hline & $6 / 18 / 2002$ & Bacillariophyta & & \\
\hline & & Achnanthes spp. & 480 & .27 \\
\hline & & Cocconeis placentula & 457 & .26 \\
\hline & & Cyclotella spp. & 2,380 & 1.34 \\
\hline & & Cymbella sp. & 12 & .01 \\
\hline & & Melosira granulata & 198 & .11 \\
\hline & & Melosira islandica & 3,340 & 1.89 \\
\hline & & Navicula spp. & 620 & .35 \\
\hline & & Rhoicosphenia curvata & 57 & .03 \\
\hline & & Chlorophyta & & \\
\hline & & Chlamydomonas spp. & 117,000 & 66.2 \\
\hline & & Eudorina elegans & 3,220 & 1.82 \\
\hline & & Cryptophyta & & \\
\hline & & Cryptomonas spp. & 9,870 & 5.58 \\
\hline & & Cyanophyta & & \\
\hline & & Anabaena spp. & 15 & .01 \\
\hline & & Gomphosphaeria aponina & 33 & .02 \\
\hline & & Euglenophyta & & \\
\hline & & Phacus spp. & 33 & .02 \\
\hline & & Trachelomonas spp. & 39,100 & 22.1 \\
\hline \multirow[t]{18}{*}{ Site 3 (epilimnion) } & $7 / 23 / 2002$ & Bacillariophyta & & \\
\hline & & Cymbella lancelata & 737 & .19 \\
\hline & & Cymbella sp. & 13 & .03 \\
\hline & & Melosira granulata & 3,240 & .84 \\
\hline & & Melosira sp. & 265 & .07 \\
\hline & & Synedra delicattissima & 25,800 & 6.70 \\
\hline & & Synedra spp. & 269,000 & 69.9 \\
\hline & & Chlorophyta & & \\
\hline & & Chlamydomonas spp. & 57,900 & 15.0 \\
\hline & & Crucigenia apiculata & 47 & .01 \\
\hline & & Pediastrum simplex & 49 & .01 \\
\hline & & Pediastrum tetras & 13 & 0 \\
\hline & & Scenedesmus bijuga & 28 & .01 \\
\hline & & Chrysophyta & & \\
\hline & & Mallomonas producta & 464 & .12 \\
\hline & & Cryptophyta & & \\
\hline & & Cryptomonas spp. & 7,220 & 1.88 \\
\hline & & Rhodomonas minuta & 3,170 & .82 \\
\hline
\end{tabular}


Table 28. Phytoplankton taxa, biovolume, and relative percentage abundance in water from Lake Olathe near dam (site 2), northeast Kansas, 2000-02. - Continued

$\left[\mu^{3} / \mathrm{mL}\right.$, cubic micrometers per milliliter of water]

\begin{tabular}{|c|c|c|c|c|}
\hline Sampling site (fig. 1) & $\begin{array}{c}\text { Date } \\
\text { (month/day/year) }\end{array}$ & Taxa & $\begin{array}{l}\text { Biovolume } \\
\left(\mu \mathrm{m}^{3} / \mathrm{mL}\right)\end{array}$ & $\begin{array}{c}\text { Relative } \\
\text { percentage } \\
\text { abundance }\end{array}$ \\
\hline
\end{tabular}

Site 3 (epilimnion)—Continued 7/23/2002 Euglenophyta

Euglena spp.

$10,300 \quad 2.67$

Phacus spp.

$520 \quad .13$

Trachelomonas spp.

6,140

1.59

Pyrrophyta

Ceratium hirundinella

$92 \quad .02$

Peridinium spp.

34

Site 2 (hypolimnion)

$7 / 23 / 2002$

Cyanophyta

Aphanocapsa delicatissima

129

Aphanocapsa spp.

6.07

Lyngbya limnetica

2,080

15.6

Oscillatoria $s p$.

72.3

Psuedoanabaena spp.

24,900

Site 3 (epilimnion)

$7 / 24 / 2002$

Bacillariophyta

Cymbella sp.

.07

Gomphonema sp.

0

Melosira granulata

2.23

Melosira sp.

1.79

Synedra delicattissima

Synedra spp.

Chlorophyta

Ankistrodesmus falcatus

Chlamydomonas spp.

10.3

Cosmarium spp.

35,300

Euastrum sp.

Eudorina elegans

Pandorina morum

Scenedesmus sp.

Staurastrum spp.

Chrysophyta

Mallomonas producta

Cryptophyta

Cryptomonas spp.

0

Cyanophyta

Anabaena spp.

Coelosphaerium maegleianum

Merismopedia elegans

Euglenophyta

Euglena spp.

2,410

70

Trachelomonas spp.

Pyrrophyta

Ceratium hirundinella 
94 Surface-Water-Quality Conditions and Relation to Taste-and-Odor Occurrences in the Lake Olathe Watershed, Northeast Kansas, 2000-02

Table 28. Phytoplankton taxa, biovolume, and relative percentage abundance in water from Lake Olathe near dam (site 2), northeast Kansas, 2000-02. - Continued

$\left[\mathrm{m}^{3} / \mathrm{mL}\right.$, cubic micrometers per milliliter of water]

\begin{tabular}{|c|c|c|c|c|}
\hline Sampling site (fig. 1) & $\begin{array}{c}\text { Date } \\
\text { (month/day/year) }\end{array}$ & Taxa & $\begin{array}{c}\text { Biovolume } \\
\left(\mu \mathrm{m}^{3} / \mathrm{mL}\right)\end{array}$ & $\begin{array}{c}\text { Relative } \\
\text { percentage } \\
\text { abundance }\end{array}$ \\
\hline \multirow[t]{24}{*}{ Site 2 (epilimnion) } & $9 / 6 / 2002$ & Bacillariophyta & & \\
\hline & & Cyclotella meneghiniana & 240 & 0.08 \\
\hline & & Melosira granulata & 90 & .03 \\
\hline & & Synedra spp. & 82,800 & 28.0 \\
\hline & & Chlorophyta & & \\
\hline & & Chlamydomonas spp. & 174,000 & 58.7 \\
\hline & & Crucigenia crucifera & 402 & .13 \\
\hline & & Pandorina morum & 41 & .01 \\
\hline & & Scenedesmus bijuga & 102 & .03 \\
\hline & & Cryptophyta & & \\
\hline & & Cryptomonas spp. & 10,100 & 3.41 \\
\hline & & Cyanophyta & & \\
\hline & & Aphanizomenon flos-aquae & 15 & 0 \\
\hline & & Merismopedia elegans & 4 & 0 \\
\hline & & Euglenophyta & & \\
\hline & & Euglena acus & 2,840 & .96 \\
\hline & & Euglena spp. & 1,610 & .54 \\
\hline & & Trachelomonas girardiana & 828 & .28 \\
\hline & & Trachelomonas hispida & 4,890 & 1.65 \\
\hline & & Trachelomonas spp. & 14,400 & 4.86 \\
\hline & & Pyrrophyta & & \\
\hline & & Glenodinium sp. & 1,140 & .38 \\
\hline & & Gymnodinium sp. & 56 & .02 \\
\hline & & Peridinium spp. & 2,530 & .85 \\
\hline \multirow[t]{17}{*}{ Site 2 (hypolimnion) } & $9 / 6 / 2002$ & Bacillariophyta & & \\
\hline & & Achnanthes spp. & 582 & 1.51 \\
\hline & & Synedra delicattissima & 2,410 & 6.28 \\
\hline & & Synedra spp. & 2,840 & 7.40 \\
\hline & & Chlorophyta & & \\
\hline & & Ankistrodesmus falcatus & 40 & .10 \\
\hline & & Pediastrum simplex & 59 & .15 \\
\hline & & Scenedesmus arcuatus & 53 & .14 \\
\hline & & Cyanophyta & & \\
\hline & & Aphanocapsa delicatissima & 945 & 2.46 \\
\hline & & Aphanocapsa spp. & 383 & 1.00 \\
\hline & & Aphanothece sp. & 343 & .89 \\
\hline & & Lyngbya sp. & 1,840 & 4.80 \\
\hline & & Oscillatoria anguina & 81 & .21 \\
\hline & & Oscillatoria sp. & 1,430 & 3.72 \\
\hline & & Euglenophyta & & \\
\hline & & Euglena spp. & 27,400 & 71.3 \\
\hline
\end{tabular}


Table 28. Phytoplankton taxa, biovolume, and relative percentage abundance in water from Lake Olathe near dam (site 2), northeast Kansas, 2000-02. - Continued

$\left[\mu \mathrm{m}^{3} / \mathrm{mL}\right.$, cubic micrometers per milliliter of water]

\begin{tabular}{|c|c|c|c|c|}
\hline Sampling site (fig. 1) & $\begin{array}{c}\text { Date } \\
\text { (month/day/year) }\end{array}$ & Taxa & $\begin{array}{l}\text { Biovolume } \\
\left(\mu \mathrm{m}^{3} / \mathrm{mL}\right)\end{array}$ & $\begin{array}{c}\text { Relative } \\
\text { percentage } \\
\text { abundance }\end{array}$ \\
\hline \multirow[t]{26}{*}{ Site 2 (epilimnion) } & $10 / 30 / 2002$ & Bacillariophyta & & \\
\hline & & Cyclotella sp. & $5,960,000$ & 6.39 \\
\hline & & Fragilaria sp & $3,420,000$ & 3.67 \\
\hline & & Melosira granulata & $2,180,000$ & 2.33 \\
\hline & & Melosira sp. & $5,840,000$ & 6.26 \\
\hline & & Synedra sp. & $3,380,000$ & 3.63 \\
\hline & & Synedra ulna & 360,000 & .38 \\
\hline & & Chlorophyta & & \\
\hline & & Chlamydomonas sp. & $26,600,000$ & 28.5 \\
\hline & & Coelastrum microporum & 42,200 & .04 \\
\hline & & Elaktothrix viridis & 96,000 & .10 \\
\hline & & Scenedesmus sp. & 10,600 & .01 \\
\hline & & Tetrastrum sp. & 180,000 & .19 \\
\hline & & Cryptophyta & & \\
\hline & & Cryptomonas sp. & $2,220,000$ & 2.38 \\
\hline & & Cyanophyta & & \\
\hline & & Anabaenopsis sp. & 339,000 & .36 \\
\hline & & Lyngbya limnetica & $1,720,000$ & 1.84 \\
\hline & & Pseudanabaena sp. & 226,000 & .24 \\
\hline & & Euglenophyta & & \\
\hline & & Euglena sp. & 640,000 & .69 \\
\hline & & Phacus sp. & $1,230,000$ & 1.32 \\
\hline & & Trachelomonas girardiana & $1,210,000$ & 1.29 \\
\hline & & Trachelomonas hispida & $4,180,000$ & 4.48 \\
\hline & & Trachelomonas spp. & $28,800,000$ & 30.8 \\
\hline & & Trachelomonas volvocina & $4,650,000$ & 4.98 \\
\hline
\end{tabular}

